t.

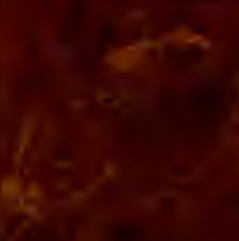

6
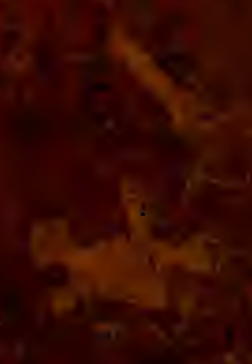

$2 x$ 


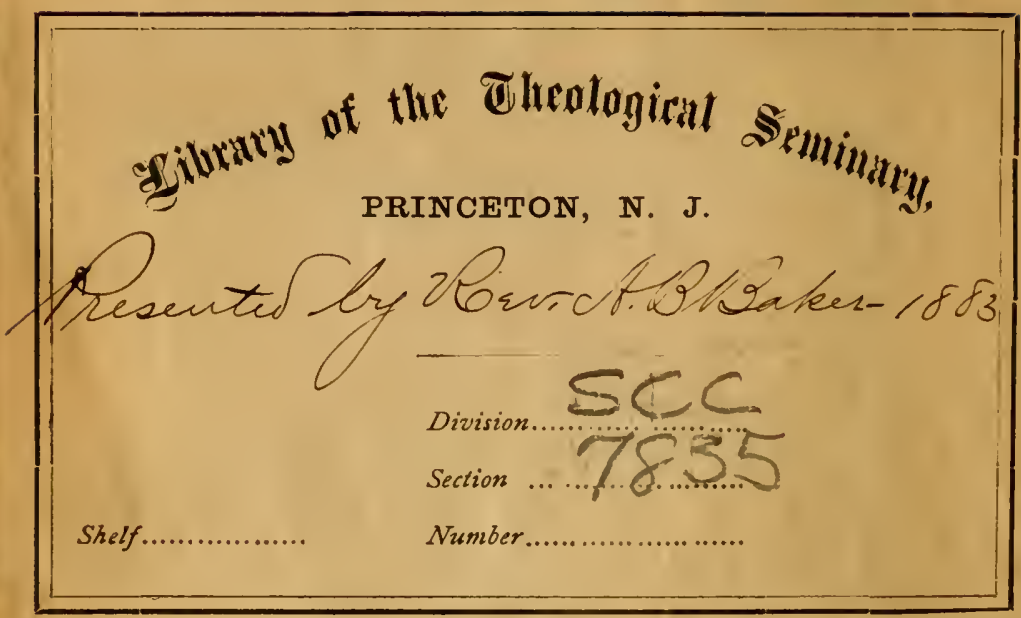






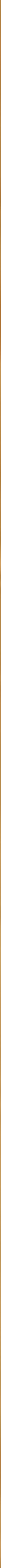



Digitized by the Internet Archive in 2011 with funding from Princeton Theological Seminary Library 


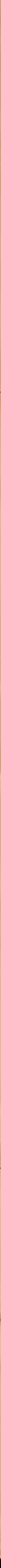




\section{NATURALAND CIVIL}

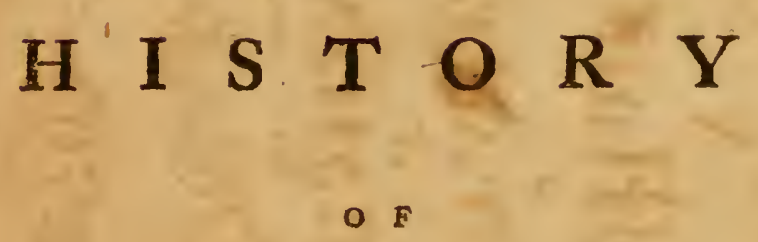

V E R M O N T.

BY SAMUEL'WILLIAMS, LL. D.

MeMBER OF The Meteorologicai SOCjety IN Germa. Ny, of the Philosophical Society in Philadel. PHIA, AND OF THE ACADEMY OF ARTS AND SCIENCES $1 \mathrm{~N}$ MASSAGHUSITS.

Publifhed according to ACT of CONGREss.

PRINTED AT $\dot{W} A L P O L E$, NEWHAMPSHIRE, BY ISAIAH THOMAS AND DAVID CARLISLE, JU'. Sold at their BookstorE, in Walpole, and hy faid Tromas, at his BOOKSTORE, in Worceftr. 


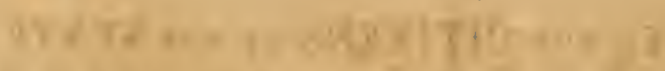

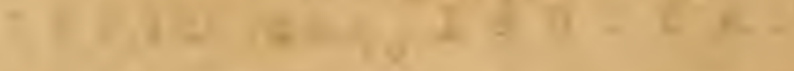

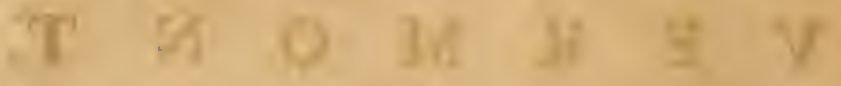
How

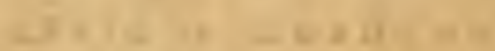

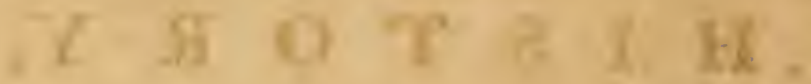

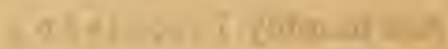

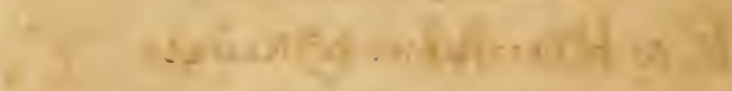
tim and yw-

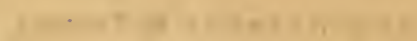

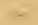

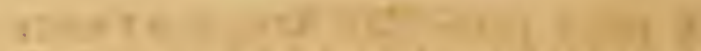
U.

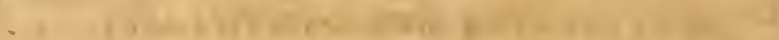
cong

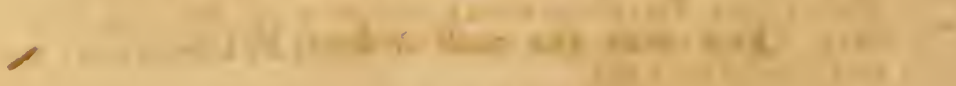

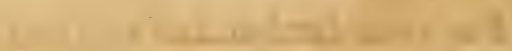

$$
\begin{aligned}
& \text { WHA YHIS. }
\end{aligned}
$$

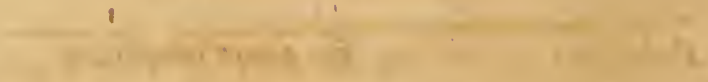

$$
\begin{aligned}
& \text { ins. }
\end{aligned}
$$

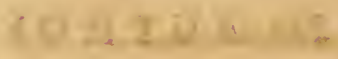

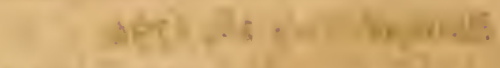

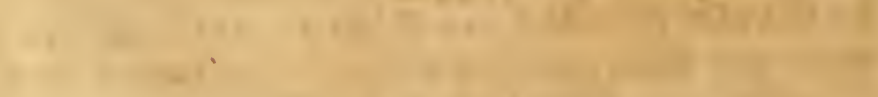


TO THE CITIZENS OE THE STATE

$$
\text { O F }
$$

$V \quad E \quad R \quad M \quad O \quad N \quad T$,

THE FOLLOWING OBSERVATIONS

ON THEIS

NATURAL AND CIVIL

HIS $I S R$,

Are humbly INSCRIBED;

As a Testimony of RESEect

For their many VIRTuEs, As an Artempt to Promote

A more particular Aceuaintance

With their own AfFAIRs,

And with the moft ardent WISies

For their further IMPROVEMEN I

And Prosperity,

By their obedient

and humble Servant,

The AUTHOR.

Rutland, Fuly $16,1794$. 


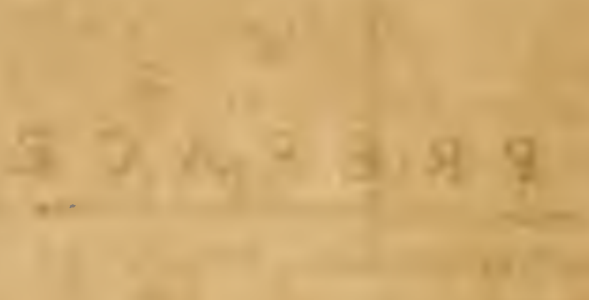

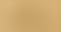

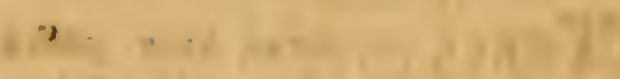

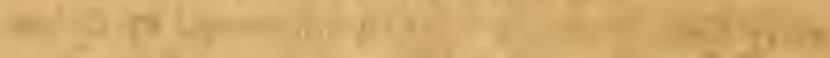

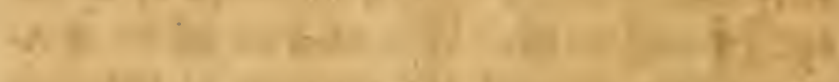

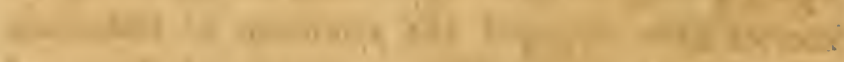

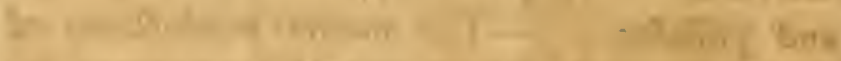

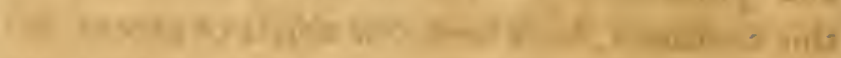

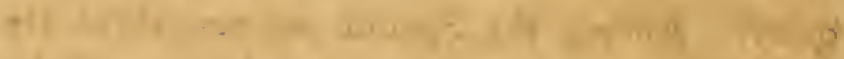

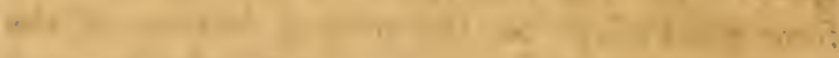
i.

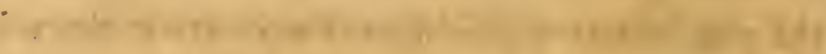
$+0$

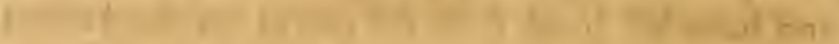

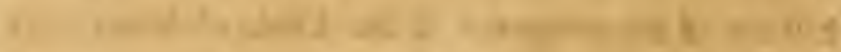

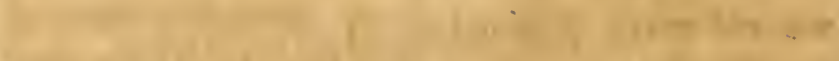

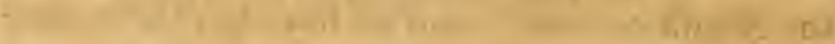

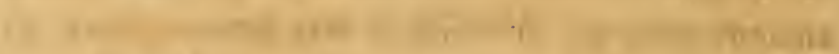

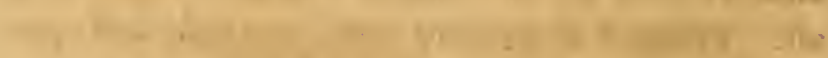

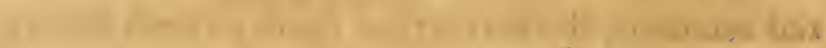

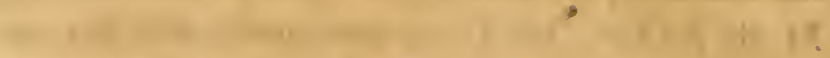

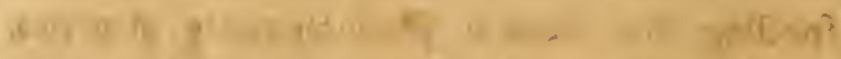

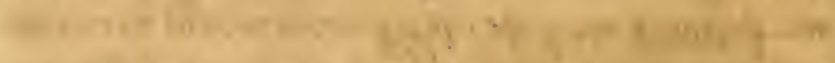

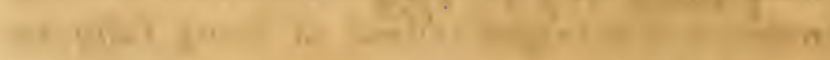

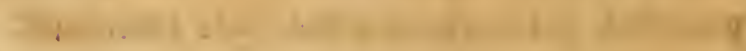

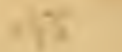




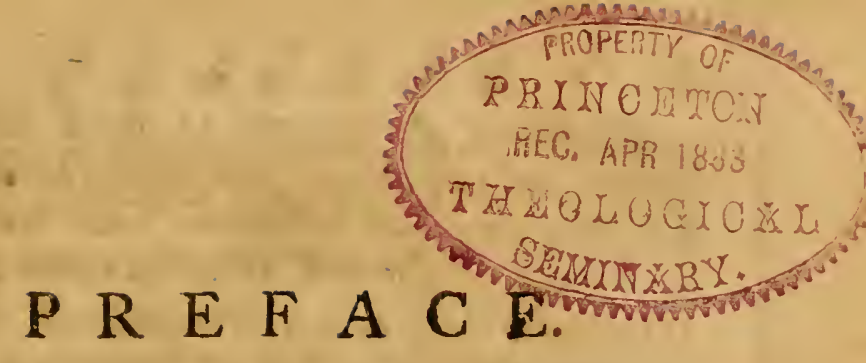

Three centuries have paffed away fince America was firft difcovered by Colusm bus. From that time until now, the affairs of $A$. merica have engaged the attention of hiftorians and philofophers.-The natural productions of this continent, have been one object of general inquiry. Among the Spanifh writers, there are fome good effays on the natural hiftory of the fouthern parts of America. In Canada, fome of the phy ficians and jefuits were attentire to the ratural productions of that part of the continent; and have left fome valuable pieces on the natural hiftory of Newfrance. This kind of knowledge was not much attended to, by the firt fettlers of the Britifh colonies; and we have but few of their ancient writings, in which it was contemplated at all. Obliged to depend upon tranfient and partial accounts, the belt writer upon natural hiftory, M. de Buffon, has fallen into many miftakes refpecting the natural productions of America, which, more accurate obfervations would have corrected. The fubject inftead of being fully explored, is yet a treafure but little examined. 
Tbe Man of America was an object Aill more curious and important. But the age in which the firft difcoveries and fettlements were made, was not enouch enlightened, to afford either accurate or impartial obfervations, on the manners, cuftoms, language, abilities, or ftate of fociety, among the Indians. Prejudiced by their fordid manners, and enraged by their barbarities, the men of $\mathrm{Eu}$ zope never looked for any thing good in fuch men: And while intere凡 and revenge joined to deftroy that unhappy race, but few were able to confider eheir cuftoms or rights with calmnefs, or dared to fay any thing in theirfavour. - It is not more than half a century, fince this fubject has been properly attended to by philofophers: And their conclufons have been of the moft oppofite and contrary sinds. Some have with great zeal advanced, that the perfection of man was to be found in the favage ftate; while others have as warmly contended, that this was the loweft ftate of degradation and abafement, to which the human race can porfbly be reduced. Such oppolite and contrary fyftems make it neceffary to examine this part of the natural hinory of man, with great eare and im. partiality; that we may diftinguifh what was val. uable in that ftage of fociety, and what was difadvantageous and degrading.

AN object of fill higher magnitude and importance, has been prefented to our view by the American Revolution. The firft fettlers in the Britin colonies were left in a great mealure by their

Lovereigns, 


\section{$P R$ E: F A C E. vigh}

iovereigns, to take care of themfelves. The only frtuation which they could take, while they were clearing the woods and forming their fettlements, was that of equality, induftry, and economy. In fuch a frtuation every thing tended to produce, and to eftablifh the fpirit of freedom. Their employments, cultoms, manners, and habits; their wants, dangers, and interefts, were nearly the fame; thefe, with every other circumftance in their fituation, operated with a fteady and certain tendency, to preferve that equality and freedom, which nature had made. - This fpirit of freedom was in fome degree checked by the cuftomary inserpofitions of royal authority: But thefe were too irregular and contradiEtory, to become matters of veneration, to alter the natural feelings of men, or to change the natural courfe and tendency of things: And while the minifters of kings were looking into their laws and records, to decide what thould be the rights of men in the colonies, nature was eftablifhing a fyftem of freedom in America, which they could neither comprehend, or difcern. The American Revolution explained the bufinels to the world, and ferved to confirm what nature and fociety had before produced.

II A INC affumed their rank among the nations of the earth, the ftates of America now prefent to the world a new fate of fociety; founded on principles, containing arrangements, and producing effects, not vifible in any nation before. The uncomrnon and increaling profperity which has at- 
viii F $R \quad E \quad F \quad A \quad C$ E.

tended it, has afcertained its fpirit and tendericy : The people are diftinguifhed by the fpirit of inquiry, induftry, economy, enterprize, and regularity : The government is dependent upon, but guides, and reverences the people : And the whole country is rapidly increafing in numbers, extent, wealth, and power. The higheft perfection and felicity, which man is permitted to hope for in the prefent life, may rationally be expected in fuch a ftate of fociety : And it becomes of courfe the object of univerfal inquiry and attention.

ro reprefent the fate of things in Anerica in a proper light, particular accounts of each part of the federal union feem to be neceffary; and would anfwer other valuable purpofes. An able hiforian, the Reverend Dr. Belknap, has obliged the world with the Hiftory of Newbampsire. The following treatife is defigned to defcribe the operations of nature and fociety, in the adjacent ftate of Vermont. This is the youngeft of the flates, an inland country, and now rapidiy changing from a vaft tract of uncultivated wildernefs, to numerous and extenfive fettlements. In this flage of fociety, induftry and economy feem to produce the greateft effects, in the fhorteft periods of time.

THE manner in which the work has been executed, I am apprehenfive will require much candour in the reader. In the variety of fubjects which have come under contemplation, I cannot flatter myfelf, that I have been free from errors 


\section{P R E F A C E. is}

and miftakes : And the reafon why feveral of the fubjects are fo imperfectly confidered, was becaufe I had not the ability or information to ftate them otherwife.

THE American war confidered with refpec to its caufes, operations, or effects, prefents to our view fome of the moft important events, which have taken place in modern times: But neither of thefe particulars can be comprehended in the hiftory of any particular ftate. To give fuch an imperfect view of this fubject as could be properly contained in the hiftory of Vermont, did not appear eligible. No further accounts therefore of the war, are inferted, than what appeared receffary to explain the fubject, which I had more particularly in view.

тि $\mathrm{z}$ controverfies which took place between the ftates of Vermont, Newyork, and Newhampthire, were of the molt dangerous nature; and they were agitated for a while, with a violence greatly unfavourable to the peace and fafety of the whole union. Moft of the wars which have taken place among mankind, have been occafioned by difputes refpecting territory and juriddiction : And however juft or proper if miglit be for any nation, to give up part of its territory and dominion to its neighbours, fuch a facrifice was fcarcely ever made svithout compulfion and force:-To have expected Newyork would voluntarily give up part of her territory, when the decifiors of the king, and the law were in her favour, was to ex- 
pect that which is never done by any fovereign or nation, while they have power to prevent it. To have expected the people of Vermont would voluntarily fubmit to a government, which fet afide their titles to the lands which they had pur. chafed of the crown, and made valuable by their labours and fufferings, was to look for that, which no people ever ought to fubmit to, if it is in their power to avoid it.-When the ftates of Newyork, Newhamphire, and Vermont, had engaged in a controverfy of this kind, it was more agreeable to the courfe of human affairs to expect it would produce a civil war, than to look for fo much wir? dom and moderation ainong either of the contending parties, as to prevent it.

In relating thefe controverfies, I have felt a conftant anxiety, left I thould mifreprefent the proceedings of either of thole nates. I had not the interefts or the paffions which thofe parties produced, to guard againf ; nor am I apprehenfive that prejudice has mifled $m e$, in relating any of thofe matters. But it is not improbable that I have not had complete information in fome paiticulars, refpecting thofe complicated controverfies; and may have miflaken the views of parties, in fome of their leading tranfactions. If this Thould be found to be the cafe, it will give me great pleafure to receive fuch further information, as fhall enable me to correct any mifiakes. Thofe who point out to us our errors, perform the fame friendly office, as thole who help us to new truths. 


\section{$P \quad R \quad E \quad F \quad A \quad C \quad E$. xi}

THE molt important of all our philofophical fpeculations, are thofe which relate to the hiftory of man. In molt of the productions of nature, the fubject is fixed, and may always be found and viewed in the fame fituation. And hence a fteady courfe of obfervation, ferves to difcover and af: certain the laws by which they are governed, and the fituation they will affume in other periods of time. It is probable the actions and afrairs of men are fubject to as regular and uniform laws, as other events : And that the fame fate of fociety will produce the fame forms of government, the fame manners, cuftoms, habits, and purfuits, among different nations, in whatever part of the earth they may refide. Monarchy, freedom, fuperfition, truth, and all tlie general caufes which aftuate mankind, feem every where to bear the fame alpect, to operate with the fame kind of influence, and to produce fimilar effects; differing not in their nature and tendency, but only in the circumftances and degrees, in which they influence different nations. - But nothing is ftationary, nothing that deperds upon the focial ftate, is fo unalterably fixed, but that it will change and vary with the degradation or improvement of the human race. And hence, while the nature of man remains unaltered, the nate of fociety is perpetually changing, and the men of one age and country, in many refpects appear different from thole of another. And as men themfelves are more or lefs improved, every thing that conftitues a part 
of the focial ftate, will bear a different appearance among different nations, and in the fame nation in different circumftances, and in different periods of time.-To afcertain what there is thus peculiar and diftinguifhing in the ftate of fociety in the federal Union, to explain the caufes which have led to this ftate, to mark its effect upon human happinefs, and to deduce improvement from the whole, are the moft important objecis which civil hiftory can contemplate in America: And they are objects, every where more ufeful to men, than - any refinements, difinctions, or difcoveries, merely fpeculative.

I HAVE wifhed to keep fuch objects in view, in confidering the îate of fociety in this part of the continent : But it is with diffidence that I fubmit the attempt to the view of the public. The difpofition of America is to favour fuch attempts and publications, as are adapted to promote any valuable public purpofe: But fpeculative and ufelefs effays cannot much engage the attention of a people, whofe main object is the profperity and improvennent of their country. The public fentiment will be a juft decifion, among which of thefe, the following work ought to be placed. 


\section{O N T E N T S.}

C H A P. I.

G Pağeq Soil, and Face of the Country.

\section{H A P. II.}

Mountains.- Tbeir Direction, Altilude, Tops, Caverns, the origin of Springs and Rivers.

\section{C $\mathrm{H}$ A $\mathrm{P}$. III.}

RIVers AND Lakes.-The Situation, Crinnnels, Intervales, Courses, Deptbs, and Effects of the Rivers. An Account of Lake Cbamplain, and Mempbremagog.

$$
\text { C H A P. IV. }
$$

Climate.-An Account of the Temperature, Winds, Rain, Snow, and Weatber. The Change of Climate subich loas attended the Cultivation of the Country.

\section{H A P. V.}

Vegetabie Productions.-Foreft Trees, efculent andmedicinal Vegetables. Remarks on tbe Magnitude, Number, Age, Evaporation, Emifion of Air, Heat, and Effects of the Trees. 66 C H A P. VI.

Native Aivimals.-An Account of the 2uadrupeds; witb Obfervations on tbeir Enumeration, Origin, Migration, Species, Magnitude, Difpofition, and multiplying Power. Tbe Birds, Fifbes, Reptiles and Infects.

C H A P. VII.

ORIGINAL INHABITANTS.-The Employments, Civil Government, Syftem of War, Education, Manners, and Cuftoms of the Indians; the Advantages, and Difadvantages of the Savage Siate. 


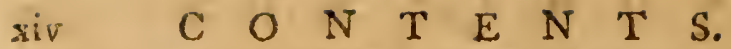

\section{H A P. VIII.}

Page,

Obfervations on the Origin of the Indians, their Antiquity, Progre/s of Society, and Tendensy to Diffolution.

\section{H A P. IX.}

Firft Setulement of Vermont by the Engliph. Grants from Newbamphire. Proceedings of Newyork. Violent Oppofition of the Setilers. American War. Declaration of the Freedom and Independence of the State.

C H A P. X.

Proceedings of Newyork. Refolves of Congrefs. Controvkrfy with Newbampßire. Claims of Newbanpfbire, Newyork, and Mafacbufelts. Appointment of Commidioners, to confer with the Inbabitants. Interpofition of Congrefs. Conduit of Vermont. Meafures purfued by Congrefs. Furtber Claims of Vermont. Pro. cesdings and Views of the Britifh Generals, and Minifters. Refolutions of Congress. Proceed. ings of Vermont, Newyork, and Newbamp/ire. Advice of General Waßington. Proceedings of Vermont. Voies of Congre/s. Remarks on the Defign, and Effer of those Votes.

$$
\text { C H A P. XI. }
$$

Difurbances in Vermont. Refolutions of Congress. Remonferances againft the proceedings of Congrefs. Peace with Greatbritaix. Difinclination of Vermont to an Union with the confederated States. New federal Conftitu. xion. Propojals from Newyork. Settlement of the Controverfy with that State. Admifion of Vermont into the federal Union. Political Effiets of these Controverfies.

$$
\text { C H A P. XII. }
$$

STATE OF Societr.- The Employments of the People: Agriculture, Manufaetures, Hinting, the Profits of Labour. 


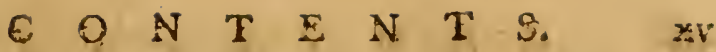

C H A P. XIII.

St'Ate or Society.-Cuftoms and Manners :

Education, early Marriages, Azrivity, Equaliry, Economy, and Hofpitality of the Peogle.

\section{H A P. XIV.}

State of Society.-Religion: Importance of this Principle, Danger of any Controul in it, Equality of all Denominations, Effect of this Equality, Grants and Laws for the Support of Religion, Extent of Religious Liberty, Corsnexion of Religion with Science and Education. 334

$$
\text { C H A P. XV. }
$$

State or Societry.-Nature of the American Government. Confitution of Vermont, Laws, Counties and Courts, Annual Expenfe of Governiment, Public Revenue, Militia, Popularity of the Government.

C H A P. XVI.

Srate of Society.-Population: Caujes on wobich this depends, the mean Period of Human Life in the American States, Period of doubling in Vermont, comparative View of Popula. tion in nere and old Countries.

\section{H A P. XVII.}

State or Society.-Freedom: Deftroyed in fome Countries by the State of Society, produced by the Selllement of America, the Caufe and Effect of the American War, cannot be preferved by Government, depends on the State and Condition of the People. 
$\begin{array}{lllllllll}\text { xyi } & C & O & N & T & E & N & T & S\end{array}$

\section{A P P E N D I X.}

N U M B E R

Page.

An Account of the Variation of the Magnelic Needle, in the Eaftern States.

$\mathrm{N}$ U M B E R II.

Obferyations on the change of Climaie in Europe, and other places.

\section{$\mathrm{N}$ U M B E R. III.}

380

A Differtation on the Colours of Men, particu-

- larly on that of the Indians of America.

$$
N \text { U M B E R IV. }
$$

The Declaration and Petition of the Inhabitants of the Newhampfhire Grants to Congress, announcing the Diffritt to be a Free and Independent State.

$$
\text { N U M B E R V. }
$$

The Remonftrance of the Commiffioners from Vermont againft the Proceedings of Congress, September $22,1780$.

\section{N. U M BE R VI.}

Queftions propofed by the Committec of Congrefs to the Agents on the part of Vernont, with the Anfwers of the Agents, Auguft 18, 178 1.

N UM B ER VII.

An.Account of the Ratable Property, ard of the Number of the Inhabilants in Vermort, at different Periods, of Time. 


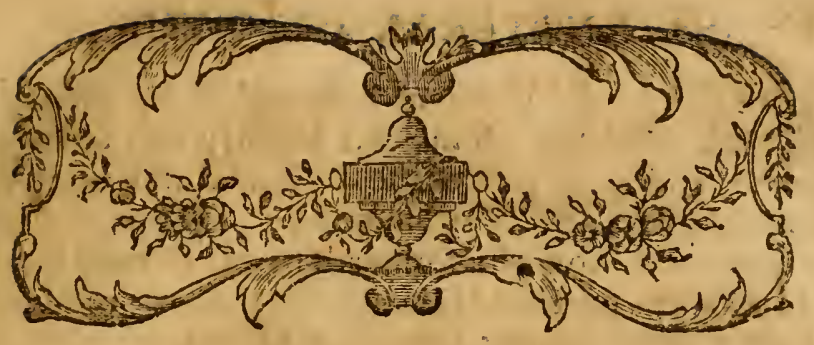

T \&

\section{NATURAL AND CIVIL}

\section{HISTORY OF VERMONT.}

\section{C $\quad$ H A P. I.}

Sitwation, Boundaries, Area, Soil, and Face of tiò Country.

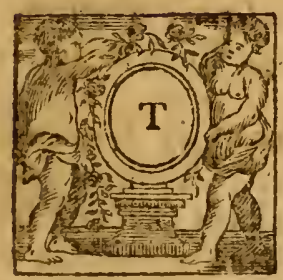

HE ftate of Vermont is fituated between $4^{\circ} 44^{\prime}$, and 45 degrees of north latitude; and between $1^{\circ} 43^{\prime}$ and $3^{\circ} 3^{\prime}$ of longitude, eaft from the meridian of Philadelphia. It is altogether an inland country; furrounded by the fates of Newhampfhire, Maffachuletts, Newyork, and the province of Canada: That part of the ftate of Vermont which is neareft to the feacoaft, is at the diftance of feventy or eighty miles, from any part of the ocean. 
On the fouth, Vermont is bounded by the ftate of Maffachufetts. This line is forty one miles in length, and was a part of the divifional line between Mallachuletts and Newhamplhire. It was derived from the decifion of a former king of Greatbritain : On March 5, 1740, George the fecond, refolved, "That the northern boundary of the province of Mafrachufetts, be a fimilar curve line, purfuing the courfe of Merrimack river, at three miles diftance, on the north fide thereof, beginning at the Atlantic oceans, and ending at a point due nortb of $\mathrm{Pa}$ tucket falls; and a fraight line drawn thence due rvelt, until it meets with his Majelty's other governments." The point three uniles north of Patucket falls, was found to be in the town of Dracut. From that point, the furveyor, Richard Hazen, in the months of February and March, 1741, ran the divifional Jine between Maffachufetts and Newhampfhire. He was directed by Mr. Belcher, at that time governor of both thofe provinces, to allow ten degrees for the wefterly vasiation of the magnetic needle. The magnetic variation, at that time and place, was not fo great, as the furveyor affumed: And when he arrived at Connecticut river, a diftance of fifty five miles, inftead of being in a weft line, he had deviated to the north $2^{\prime} 57^{\prime \prime}$ of latitude. This error in the direction of the line, occafions a lofs of 59,873 acres to Newhamplhire; and of 133,897 acres to Vermont.

The eaftern boundary of Vermont, is formed by the weft bank of Connecticut river. This line, following the courfe of the river, is about two hundred miles; and is derived from the decree of George the third. On the 20 th of July, 1764 , his Majefty ordered and declared, "The weftern banks of the river Connecticut, from where it enters the province of Maffachufetts Bay, as far north as the forty fifth degree of northern latitude, to be the boundary line between 
between the two provinces of Newhamplhire and Newyork."

The north line of the ftate begins at the latitude of 45 degrees north, and runs upon that parallel, from Lake Champlain to Connecticut river. fiThis line is ninety miles and one quarter of a mile long, and divides this part of the United States from the province of Canada. Much pains was taken by the provinces of Newyork and Canada, to afcertain the latitude of 45 by aftronomical obfervations. This was done by commiffioners from both provinces, in the month of September, ${ }^{17} 67$. At the place where the line croffes Lake Champlain, they erected a monument of ftone, which is yet ftanding. The line was afterwards run by Mr. Collins, but with what accuracy has not fince been examined.-This line arifeth from the proclamation of George the third, of Oetober $7,176_{3}$, determining the fouthern boundary of the province of Quebec; and from the treaty of peace between Britain and the ftates of America, in 1783 .

Beginning at the fouthweft corner of the town of Pownal, the weft line of Vermont runs northerly, along the weftern boundaries of the townfhips of Pownal, Bennington, Shaftfbury, Arlington, Sandgate, Rupert, Pawlet, Wells, and Poultney, as the faid townfhips are now held and poffeffed, to the river commonly called Poultney river; thence down the fame, through the middle of the deepeft channel thereof, to Eaft Bay ; thence through the iniddle of the deepeft channel of Ean Bay, and the waters thereof, to where the fame communicate with Lake Champlain; thence through the middle of the deepeft channel of Lake Champlain, to the eaftrard of the iflands called the Four Brothers, and to the weftward of the inands called the Grand Ine, and Long Ine, or the Two Heroes, and to the weflward of the Ine la Mott, to the forty fiftl degree of north 
latitude. - This line is about one hundred and fev: enty miles in length; and refults from the declaration of the commifloners of Newyork, of October 7,1790 ; and the concurring act of the general af fembly of the flate of Vermont, paffed Octobe: 28, 1790 .

Computing by the latitudes, the length of the nate from the fouthern to the northern boundary, is one hundred and fifty feven miles and an half: The mean width from ealt to weft is about fixty five miles. This will give $10,237 \frac{x}{2}$ fquare miles, or $6,55^{2}, 000$ acres, as the fuperficial area contained within the boundaries of Vermont ; but a confiderable deduction mutt be made, to exclude the waters and reduce it to the junt quantity of land.

The land included within thefe limits, is of a very. fertile nature, fitted for all the purpoles and pro. ductions of agriculture. The foil is deep, and of a dark colour; rich, moilt, warm, and loamy. It bears corn and other kinds of grain, in large quantities, as foon as it is cleared of the wood, without any ploughing or preparation : And after the firft crops, naturally turns to rich pafture or mowing.

The face of the country exhibits very differen profpects. Adjoining to our rivers, we have the wide extenfive plains, of a fine level country. At a fmall diftance from them, the land rifes into a collection and chain of high mountains, interfected with deep and long valleys. Defcending from the mountains, the ftreams and rivers appear in every part of the country, and afford a plentiful fupply of water. 


\section{H A P. II.}

Mountains.-Their Direttion, Altitude, Tops, Caverns, the Origin of Springs and Rivers.

\section{IN the formation of our mountains,} nature has conftructed her works on a large fcale: and prefents to our view objects, whofe magnitude and fituation, naturally engage our attention. Through the whole tract of country which lies between the welt fide of Connecticut river, and the eaft fide of Hudfon's river, and Lake Champlain, there is one continued range of mountains. - Thefe mountains begin in the province of Canada: From thence, they extend through the ftates of Vermont, Maffachufetts, and Connecticut, and terminate within a few miles of thefea coaft. Their general direction is from N. N.E. to S. S. W.; and their extent is through a tract of country, not lefs than four hundred miles in length. - They are one continued range or collection of mountains, appearing as if they were piled one upon another. They are generally from ten to fifteen miles in width, are much interfected with valleys, abound with fprings, and freams of water, and are every where covered with woods. Their appearance, is among the moft grand and majeftic phenomena, which nature exhibits.From the perpetual verdure which they exhibit, they are called the Green Mountains ; and with great propriety their name has been affigned to the ftate.

The altitude of mountains, has been one of the clurious inquiries, which the philofophers of this

century 
century have been folicitous to determine. The mof common method of meafuring their heights, has been by the Barometer. I do not know that in many cafes, a better method could have been applied. The theory however of this, is not attendcd with certainty, or precifion : And in its application, it has generally given very different altitudes, to the fame mountain. Geometrical menfurations admit of greater certainty and fimplicity, where they can be applied : But the difficulty and expenfe of making fuch menfurations, has prevented any great progrefs from being made, in this part of the natural hiftory of the earth. In North America, the height of moft of our mountains, remains yet to be determined.-In December, 1792, I attempted to afcertain the altitude of Kellington Peak, one of the highef of the green mountains, by a geometrical procefs; and had the happinefs to fucceed in the menfuration. The meafures ftood thus, Height of Kellington Peak above the plain at the State Houle in Rutland, by geo. metrical menfuration, - $\quad 2813$.

Height of the State Houfe above the waters of Lake Champlain, deduced from the menfuration of the falls of Ottercreek, and a computation of other defcents,

Defcent of the water from that part of Feet. Lake Champlaia where the current begins, to St. John's ; a diftance of fifty miles. Eftimated at twelve inches to

Falls between St. John's and Chamble. Entimated, 10.

Defcent of the water from the bafon of Chamble to Quebec, a diflarce of one hundred and eighty miles. Eftimated at twclve inches to a mile, 
Admitting the waters of the river St. Lawrence at Quebec, to be of the fame level as the fea, the altitude of Kellington Paak by thefe meafures and computations, is 3454 feet above the level of the ocean. The altitude at which a perpetual congelation takes place in this latitude $\left(43^{\circ} 30^{\prime}\right)$ is about 8066 feet above the level of the fea. This is probably four fifths of a mile, higher than the tops of our highelt mountains*. But although they are far below the

freezing

* Mount Blanc in Savoy, is the higheft mountain in Europe, and probably the higheft in the other hemifptiere. In 1787 its altitude was found by M. de SaulJur to be $15.673 \mathrm{Eng}$ lin feet above the level of the fea. In the fouthern parts America M. Bougutr found the higheft part of the Cordilleras, to be 20,590 feet in height; this is the higheft of any upon the globe.-In Virginia, according to Mr. Fef'erjon, the mountains of the Blue ridge, and of thefe the Peaks of Otter, are thought to be of the greateit height, meafured from their bafe. "From data," faith he, "which may found a tolerable conjęture, we fuppofe the higheft peak to be about 4000 feet perpendicular." (Notes on Virginıa, Phila. Eóit. p. 18.)The white mountains in the northeafterly part of Newhampfhire, are generally efteemed to be the higheft lands in Newengland. Their altitude has not been determined by geometrical menfuration, but there is one circumftance attending their phenomena, which may ferve to denote their altitude, with much probability. From the obfervations which have been made of their tops, it appears that the altitude of the higheft of the white mountains, is below the point of perpetwal congelation. On June 19,1774 , on the fouth fide, in one of the gullie, the fnow was five teet deep. On September 1, 1783 , the tops of the mountain was covered with ice and fnow, newly formed. In $178 \mathrm{f}$, fnow was feen on the fouth fide of the largeft mountain, until July 12 th. In 1790 , the fnow lay until the month of Auguit. In general, the mountain begins to be covered with fnow as early as September; hut it goes off again, and felo'om becnmes fixed until the end of Ottober, or the beginning of Noveniber: But from that time, it remains unil July. (Belknar's Hift. Newliamphire, 3. 46, 47.)-From thefo obfervations it is apparent, that the white mountains rife nearly to the line of perpetual congelation in that latitude, but do not fully come up to it. Thefe mountains are in the latitude of $44^{\circ} 15^{\prime}$ north. The line of perpelual congelation in that latitude, as deduced from the obfervations which have been 
freezing point in fummer, their phenomena and productions are very much affected by the degree of cold, to which they are conftantly expofed.

The tops of our mountains are generally compofed of rocks, covered over with mols. The trees appear to be very aged, but they are of a fmall fize; and all of them are of the fpecies called evergreens; pine, fpruce, hermlock, and fir ; intermixed with thrubs and bufhes, The powers of vegetation regularly diminifh, as we approach the fummit of an high mountain; the trees degencrate in their dimenfions, and frequently terminate in a fhrubbery of fpruce and hemlock, two or three feet high; whofe branches are fo interwoven and knit together, as to prevent our paffing between them. Trees thus diminifhed, with thrubs and vines bearing different berries, and a fpecies of grafs called winter grafs, mixed with the mols of the rocks, are all the vegetable productions, which nature brings forth on the tops of our higheft mountains.

The fides of our mountains are generally very irregular, and rough; and fome of them appear to have large apertures, or openings among the rocks. Among thefe fubterraneous paffages, fome caverns of a confiderable extent have been found. One of thefe is at Clarendon, on the foutheaft fide of a mountain, in the wefterly part of the town. The snouth of the cave is not more than $2 \frac{1}{2}$ feet in diameter. In its defcent, the parfage makes an angle with the hoiron of 35 or 40 degrees; but contin. ues of nearly the fame diameter, through the whole length,

Inace in Europe, is 7872 feet above the level of the fea. F From the greater coldnefs of the American climate, the point of perpetual congelation in a fimilarA merican latitude, cannot exceed, but muft rather fall fomething hort of this. The altitude therefore of the white mountains, cannot be eftimated as more than 7800 feer above the level of the ocean: A od this is probably. the altitude of the higheft mountains in the eaftern ftates. 
length, which is thirtyone feet and an half.-At that difance from the mouth, it opens into a fpacious room; twenty feet.long, twelve feet and an half wide, and eighteen or twenty feet high. Every part of the floor, fides, and roof of this room, appear to be a folid rock, but very rough and uneven. The water is continually percolating through the top, and has formed. Atalactites of various forms; many of which are conical, and fome have the appearance of maffive columns.-At the north part of this room, there is another aperture of about forty inches diameter, very rough, and uneven. This aperture is the beginning of another paffage, through the internal parts of a folid rock: "The direction of this paffage is oblique, and full of ftops or notches, and its length about twenty four feet. Defcending through this aperture, another fpacious room opens to view. The dimenfions of this apartment are twenty feet in width, thirty in length, and twenty in height. In the fpring of the year, the whole of this lower room is full of water ; and at all other feafons, water is to be found in the lower parts of it.-No animal has been found to refide in this cave, and it evidently appears to be the production of nature, untouched by the hand of man. - Another of thefe caverns is at Danby, and a third at Dorfet. Thefe are faid to be more curious than this at Clarendon, but they have not been properly explored. There are others in different parts of the fate: All of them are the genuine productions of nature; never altered by art, and never inhabited by any of the humán race.

One of the moft curious and important operations which nature carries on in the mountains, is the formation of fprings and rivers. All our freams of water in Vermont, have theit rife among the greera mountains: From a number of thefe uniting, are formed all thofe brooks and rivers, which run in different directions through the various parts of the 
country : And in general, the origin of rivers is to be found in the mountains, or high lands. In what manner do the mountains ferve to produce thefe effects? And whence is it, that the higheft mountains attract, collect, become the relervoirs, the receptacles, or the fource, of the largeft and molt conftant collections of water? One part of this effect, feems to be derived from the conftant afcent of the waters, from the bowels to the furface of the earth. That water is contained in large quantities in the bowels of the earth, is evident from the fprings which are found in almoft all declivities; and from thofe which every where fupply wells, at the depth of twenty or thirty feet from the furface of the earth. That thefe waters are conftantly afcending towards the furface of the earth, and going off into the atmolphere, is evident from the evaporation which is conftantly taking place, and from the manner in which heat, or as it is generally expreffed, a drought affeets both the furface of the earth, and the fprings, by raifing and diffpating the water from both. If this afcent of the waters be obftructed by any flrata of clay, rocks, or any other fubftance, through which they cannot pass, they will collect in fuch quantities, as to form or find for themfelves a channel, through which they may be difcharged. The place of this difcharge can only be on the fide of a hill, or in fome ground below the level of that place, where they are thus collected: And at fuch a place the waters would continue to iffue out, as long as they continued to afcend, whatever might be the feverity or duration of a drought.-In fome fuch way, it appears probable to me, that fome of the fprings are formed in the mountains: By waters which are afcending towards the furface of the earth; but which, inflead of going off at the top, have their difcharge in fmall quantities, at the fides of the mountains. Any ftrata of clay, rocks, or of any other matter, 
matter, which would retain the water when it defcends in rain or dew, and produce a fpring for their defcent, would alfo prevent the afcending water from paffing through them, and might produce a fpring from their afcent. - This afcent of the waters from the bowels to the furface of the earth, is a conftant, powerful, and unceafing operation of nature : And feems to be the only caufe, which is adequate to the formation of thofe fprings, which are perennial. Such fprings could fcarcely be formed, or preferved, by the waters which defcend in rain, becaufe they are fo little affected in the fevereft droughts : In thefe feafons, inftead of being replenifhed by rain, the earth to the depth of many feet, is much exhaufted of its water by heat. And no rain can ever fall upon the furface of the earth, which was not firft carried off from it, by evaporation.

Mountains ferve alfo to form fmall ftreams and rivulets, by preventing the evaporation of water from their furfaces. The vapours out of which the clouds and rains are formed, are all of them firft raifed from the furface of the earth. When the evaporation is in an open field, expofed to the fun and wind, the exhalations are foon carried off into the atmofphere, and the furface of the earth is left dry. When the evaporation is from lands covered over with thick trees and buthes, the influence of the fun and winds are much prevented; and the waters ftagnate upon the furface of the earth, and render it wet and miry, in the form of fwamps, and confined waters. When the evaporation is from the fides and tops of mountains, covered with vegetables, the waters are but flowly carried off by the heat and wind; nor can they ftagnate, but will be gradually and conftantly defcending down the fides of the mountains, in natural or artificiall channels : And in this way, the mountains will alfo be conftantly producing linall ftreams or rivulets. 
A fimilar effect will alfo be produced by the condenfation and collection of the vapours in the at mofphere, occafioned by the height and coldnefs of the mountains. When the weather is fair and ciear, and the atmofphere ferene and pleafant in tho valleys, the tops of the mountains are often obfcured, and covered with a thick fog or cloud. In the cool mornings of the fpring and fall, the vapours form a thick fog on the fides and tops of the mountains, which do not diffolve and difappear, untit the fun has rifen feveral degrees above the horizon, and the heat is confiderably increafed. In damp and rainy weather, the largeft part of the clouds feem to collect, and diffolve upon the mountains. In winter the fnows fall fooner, lie deeper, and continue longer on the mountains, than on any other part of the coun. try. Thefe phenomena denote a greater, and a more conftant collection of vapours and clouds by the mountains, than takes place any where elfe; and it feems to be occafioned by the greater degree of cold, which prevails in thofe elevated fituations. - The higheft parts of our mountains generally abound with rocks, and are covered with large quantities of thick green mofs; fo extenfive, compact, and thick, as to reach from one rock to another, and of fo firm a contexture as to bear the weight of a man, without being broken. Thefe immenfe beds of mols retain the moifture fupplied by the clouds and rain: And while part of it runs down the fides of the mountains, part will be detained by the fpungy furface, to penetrate and fink into the earth. On this account, and for want of a more rapid evaporation, feveral of our mountains are conftantly wet on their tops, and have marfhy fpots, which are frequented by the aquatic birds. The roads over the fe mountains are frequently very wet and miry, when the valleys below are dry. - When the waters thus fupplied by the clouds and rain, meet with any ftrata which prevert their 
their defcent, they collect in fuch quantities as to form a channel, and iffue out at the fides of the mountain in the form of fprings and rivulets. All thofe fprings, which are intermitting, feem to be thus formed by the rains, or defcending waters: And the more conftant and regular the rains are, the more permanent and fteady will thefe fprings be: Such kinds of intermitting fprings are to be found in great numbers, on the fides of all high mountains. They never fail to run while the rains continue in their ufual quantities; but when the rains ceafe, and a fevere drought comes on, thefe fprings are always found to fail.

In each of thefe ways, the mountains fupply water for the fprings and ftreams, out of which, the rivers are formed: And they are fuch as can never fail, while the prefent economy of nature thall fubfift. But as the country becomes cultivated, fome of the fmaller ftreams muft decreafe ; and it is not improbable that when the woods fhall be cut down, fome of the leffer fprings will wholly difappear. 


\section{C $\mathrm{H}$ A P. III.}

Rivers and Laxes.-The Siluation, Channels, Intervales, Courfes, Depths, and Effects of the Rivers. An Account of Lake Cbamplain, and Mempbremagog.

\section{A LL the ftreams and rivers of Ver-} mont, have their origin among the green mountains. About thirty five of them have an eafterly direction, and fall into Connecticut river. A bout twenty five run wefterly, and difcharge themfelves into Lake Champlain : Two or three, running in the fame direction, fall into Hudfon's river. In the northeafterly parts of the ftate, there are four or five ftreams which have a northerly direction, and run into the lake Memphremagog; from thence, through the river St. Francis, they are emptied into the river St. Lawrence.

The molt confiderable ftreams on the weft fide of the green mountains, are Ottercreek, Onion river, the river Lamoille, and Michifcoui.-Ottercreek rifes in Bromley; runs northerly about ninety miles, and falls into Lake Champlain at Ferrifburg; and in its courfe receives about fifteen fraller ftreams. There are large falls in this river at Rutland, Pittfford, Middlebury, and Vergennes. Between thefe falls the current is very flow, the water is deep, and it is navigable for the largeft boats. Veffels of any burden may come up to the falls at Vergennes, five miles fromits mouth. The head of this river in Bromley 
Bromley, is not more than thirty feet from the head of Batton Kill, which runs in a contrary direction, and falls into Hudfon's river.

Onion river was formerly called the French rivet, and by the Indians; Winoolki. It rifes in Cabot, about fourteen miles to the weft of Connecticut river, and thirty miles to the eaft of the heights of the green mountains. A fmall foutherly branch rifes in Walhington and Corinth, not more than ten miles from Connecticut river. From this foutherly branch, Onion river runs northwefterly; about feventy five miles, and empties itfelf into Lake Champlain, between Burlington and Colchefter. This river receives fourteen fmaller Itreams; and is navigable for fmall veffels, five miles from its mouth. It has feveral falls, between which it is navigable for boats. At one of thefe falls in Waterbury, the channel of the river becomes very narrow, and paffes between a high ledge of rocks on each fide. 'A huge unfhapely rock, in fome ancient time, hath fallen from one of thefe ledges, in fuch a manner; that the whole river now runs under it. . The rock forms a kind of natural bridge, but one that can never be of any ufe; as neither the fhape of the rock, or the fituation of the adjacent banks, will ever admit of a road either to, or over the rock. About fix miles from its mouth, between Burlington and Colchefter, the channel of this river is formed by a folid rock. The channel through the rock, by eftimation, is fiftcen rods in length, fifty feet wide, and feventy feet deep. Every appearance feems to denote that this channel was formed by the water, which in this place could not have had any other paffage.- Onion river is one of the fineft ftreams in Vermont. It runs through a moft fertile country, the produce of which for feveral miles on each fide of the river, is brought down to the lake at Burlington. It was along this river, that the Indians formerly travelled from Canada, when they 
they made their attacks upon the frontier fettie: ments on Connedticut river.

The river Lamoille proceeds from a pond in Glover. Its general courfe is wefterly : After running about feventy five miles, and receiving fourteen leffer ftreams, it falls into Lake Champlain at Colchefter, five miles north of the mouth of Onion river; and is of the fame magnitude as that. - The river Lamoille is a fine, fmooth, and pleafant ftream; and runs through a rich, level, fertile, country.-The height of the land in the northeaft part of the ftate, feerns to be about Greenborough. About fix miles to the fouthweft of the origin of the river Lamoille, is Scotland pond: From this proceeds Black river, which, for five or fix miles runs in a direction oppofite to, and nearly parallel, with that of the river Lamoille, and difcharges itfelf into the lake Memphrcmagog.

Michifcoui is the Indian name of the moft northerly river in the ftate. It has its fource in Belvidere, and runs nearly northeaft until it has croffed the north line of Vermont : After running to fome diftance in Canada, it turns weft, and then foutherly, and then reenters the ftate in Richford; and falls into Lake Champlain at Michifcoui bay, in Highgate. This river is navigable for the largeft boats to the falls at Swanton, feven miles from its mouth. Michifcoui, Lamoille, and Onion river, are ncarly of the fame magnitude.

On the eaft fide of the green mountains, the rivers are not folarge as thofe on the weft, but they are more numerous. The largent of them are Wantaftitquek or Weft river, White river, and Pooufoomluck. Wantaftitquek has its main fource in Bromley, about three miles fouthealt from the head of Ottercreek. Its courfe is to the foutheaft; it receives feven or eight fmaller ftreams; and after running about thirty feven miles, falls into Connecticut river at Brattleborough. 
borough. At its mouth this river is about fifteen rods wide, and ten or twelve feet deep.

The north branch of White river, riles in Kington. The fouth branch has its fource in Philadelphia. From Kingfton, the general courfe of this river is foutherly; its length about fifty miles; it receives fix or feven leffer ftreams; and falls into Connecticut yiver at Hartford: White river abounds with falls and rapids; at its mouth it is about eighteen rods in width, but not more than ten feet in depth.

Pooufoomfuck, rifes from a pond in Weftmore. Its courfe is foutherly; it is made up of ten leffer ftreams; and after running about forty five miles, it joins Connecticut river in Barnet. It is there twelve rods wide, and eight feet deep.

Connecticut river, into which thefe ftreams fall, forms the eaftern boundary of the ftate. The original Indian name, which it ftill bears, fignifies the long river*. This river has its fource in a ridge of mountains, which extend northeafterly to the gulph of St. Lawrence. The head of its northweftern branch, is about twenty five miles beyond the latitude of forty five degrees; and fo far it bas been furveyed. When it firft enters the fate, it is about ten rods wide; and in the courle of fixty miles increafes in its width to twenty four rods. Its courfe between Vermont and Newhampthire, a diftance of two hundred miles, is fouthwefterly; from thence to its mouth, the courfe is more foutherly. After running about four hundred miles through the country, and $E$

receiving

* The names which tho original inhabitants affigned to our mountains, plains, and valleys, are moftly loft. Many of our rivers, bays, and falls of water, are yet known by thcir ancient Indian names. On account of their originality, antiquity, fignification, fingularity, and found, thefe names ought to be carefully preferved. In every refpect they are far preferable to the unmeaning application, and conftant sepesition of an improper English name.: 
receiving a great number of other ftreams and rivers, it difcharges itlelf into the ocean at Seabrook. With refpect to its length, utility, and beauty, this is one of the fineft rivers in the eaftern ftates. In the months of April or May, it overflows its banks; and for a length of three hundred miles, forms and fertilizes a vaft tract of rich meadow. Veffels of eighty or one hundred tons, go up this river as far as Hartford in Connecticut, fifty miles from its mouth. It is navigable for boats, three hundred miles further, except the falls which the ftates of Vermont, Maffachufetts, and Connecticut, are now making navigable by locks. While it increafes the richnefs, and ferves to tranfport the produce, by its perpetual majeftic movement through an immenfe tract of country, it is always adding beauty and grandeur to the profpect.

To this account of our rivers, fome obfervations may be added refpecting their operations and effects. - Their firft operation feems to have been, to form for themlelves, a channel. The higheft waters defcend along the mountains, until they meet with fome obftacle to obftruct their motion. Whatever this obftacle may be, it operates as a dam, and ferves to collect the waters into a fmall pond or lake. Two caufes are conftantly' raifing the waters, in fuch collections: The earth is perpetually brought down by the waters, to the bottom of fuch ponds; and the water is conftantly rifing by its own accumulation. When it is raifed above the banks, the waters find their paffage in the loweft part, and begin to form a channel there; and a channel thus formed, will conftantly be made more and more deep, by the perpetual running of the water. A fimilar operation muft take place through the whole courfe of the river, from its firf rife and fource, to its final difcharge into the waters of the ocean. Their channels muft at firft have been formed by their waters; which 
were conftantly accumulating, and ftumgling for a paffage, approach, or difcharge, into the neareft friuation they could take to the center of the earth.

In this defcent and paffage to the ocean, all the large rivers in this part of America, have alfo formed large tracts of intervale lands. By intervales we mean thole low lands, which are adjacent to the rivers, and are frequently overflowed by them in the fpring and fall, or whenever the waters are raifed to their greateft height. Thefe intervales are level, and extenfive plains; of the fame altitude as the banks of the river; in width they often reach from a quarter of a mile, to a mile and an half, fometimes on one, and fometimes on both fides of the river. There are frequently two ftrata of the intervales, the one four or five feet higher than the other; the higheft of which is not overflowed, but when the waters are raifed to an uncommon height; but they are level, and extenfive like the other.-Both of them have many indications, that they were formed by the waters of the rivers. The foil is always of that rich mud and flime, which is brought down by the rivers in the fpring. In digging into thefe lands, various appearances of decaying vegetables are frequently found. The frata formed at particular years, are eafily diftinguifhed; and the original and the new made foil are fo different, as to be readily known. The limbs and trunks of large, and found trees, are often found at various depths; fometimes fo low as forty feet below the furface. The frnall iflands in thefe intervales, are of a different foil, and lefs rich; and are evidently the tops of finall hills, which have not been covered by the inundations of the rivers. Thefe long and level furfaces are peculiar to the banks of rivers, and confift of the fame rich manure which are yet annually brought down, and depofited by the waters. The caufe, by which they are now annually increafed, could not fail to have 
produced fuch effects, in the courfe of a long feries of years.

In thefe intervales there are feveral plaçes, where another curious phenomenon occurs. The rivers have changed their courfes, their ancient channels are left dry, and they have formed new ones. In the uncultivated parts of the country, where the operations of nature have not been altered or changed, the traveller finds many places where the rivers formerly rolled, which are now dry, and at a confiderable diftance, fometimes a mile or more from the prefent beds of thofe rivers. In fome of thefe ancient channels, the waters mut have run for a long number of ages; as they have worn the furface of the ftones as fmooth as thofe, which are to be found on the fea fhores. In fome places the former channels are left dry, abounding with fmooth flones and rocks: In others, the channels are converted into ponds, or overgrown with bufhęs or trees. Appearances of this kind are common in all the mountainous parts of the country ; and fomething of the fame kind, is conftantly taking place in moft of our rivers. In all large ftreams, the channel is more or lefs affected every year: Strips of land, one or two rods in width, and of fome miles in length, are often carried off in the fpring; and additions are made to the banks in other places. The lands thus formed, in fome places, in the courfe of a few years amount to feveral acres, and are of an uncommon richnefs and fertility; but they are always attended with an equal lofs in fome other part of the river.

The depth of the channels which our rivers have formed, depends upon a variety of circumftances: The naiure of the foil, the declivity of the river, the fituaticon of the adjacent banks, the quantity of water, \&c. Their channels have been formed two. ways, by the wearing away of the ground in fome places, and by forming or raifing the intervale lands. 
in others; but molt generally the channels of our rivers have been formed in both there ways. In large ftreams paffing through the intervales which they have formed, and moving with a gentle force, the depth of the channels appear to have a fimilarity, or at leaft a refemblance. The depth of the channels in fuch fituations, in fundry places in Connecticut river, Ottercreek, and Onion river, is forty or fifty feet below that of the adjacent banks. But the alteration in the depth of thefe channels, is fo gradual and flow, that it has. fcarcely been perceptible, fince the firft fettlement of the country by the Englifh.

It is not anly in the channels and intervales, which the rivers have formed, that their effects are to be feen; but their operations are alfo vifible, upon the ftones and rocks. The Aones which have been conftantly wathed by the ftreams are always found to be fmooth and even; and the rocks in many places, are not only become fmooth and llip. pery, but they are much worn away by the conftant running of the water.- There is another phenomenon extremely curious, derived from this caufe ; in feveral rivers, there are holes or cavities, wrought into the folid body of large rocks, by the defcent, or circular motion of the water. At Rockingham, there is a remarkable fall in Connecticut river, where the water paffes over a bar of folid rock; and which it muft have been conftantly paffing over, ever fince the river began to flow. In the rocks at thefe falls, there are feveral cavities, which appear to have been. formed by the circular motion of finall ftones, conftantly kept in action by the force of the defcending ivaters. Some of thefe cavities are two or three feet in diameter, and from two to four feet in depth; and probably they are yet increafing. Such phenomena are not uncommon wherever there are deep falls in our rivers. But the moft fingular appearances of. 
this nature which I have ever feen, are at Cavendifh, upon Black river, near the houfe of Salmon Dutton. Here, the channel of the river has been worn down, one hundred feet : And rocks of very large dimenfions, have been undermined, and thrown down, one upon another. Holes are wrought into the rocks, of various dimenfions, and forms : Some of them are cylindrical, from one to eight feet in diameter, and from one to fifteen feet in depth: Others are of a fpherical form, from fix to twenty' feet diameter, worn almoft perfectly fmooth, into the folid body of a rock.

How long a period nature has been employed in carrying on thefe operations, we can fcarcely hope to determine. All the circumftances relating to the channels of rivers, and the intervales which they have formed, are fuch as denote periods of time very remote, and of the higheft antiquity. It can fcarcely be fuppofed that in the formation of the intervales, the annual incrcafe has amounted to the tenth part of an inch. At prefent, the frefhets in the fpring and fall, and throughout the year, do not annually depofit the one half of this quantity of earth, upon the intervales. At no place in this ftate, is there any appearance that the furface of the intervales has been raifed an inch, in the period of ten years. But admitting fuch an increafe, where the depth of the intervales are fifty feet, the period neceffary to produce fuch an effect, would be fix thoufand years. But in all fuch kinds of computation, the data which we affume, are nor marked with fufficient certainty or precifion, to leave us fatisfied with the conclufion.- The effects of the rivers upon the folid rocks, feem to be more flow, regular, and uniform. There are fituations in this, and in every part of America, where the water has been conftantly flowing over a folid body of rock, ever fince the channels of the rivers were firf formed. If we knew from obfervation, how much fuch 
rocks were worn away in one century, by the waters, we could form a pretty juft conclufion how long the waters have been running in thofe places. If the philofophers of the prefent age will make accurate obfervations of the altitude and Gtuations of fuch rocks, and put their obfervations upon record in the tranfactions of their philofophical focieties, they will enable pofterity to folve a problem, which we can hardly expect to determine in our day.

While the one half of our rivers pafs off into the ocean to the fouth, through Connecticut river, the other half find their way to the ocean, at the northeaft, through Lake Champlain and the river St. Lawrence.-Lake Champlain is the largeft collection of waters in this part of the United States. Reckoning its length from Fairhaven to St. John's, a courfe nearly north, it will amount to about two hundred miles. Its width is from one to eighteen miles, being very different in different places; the mean width may be eflimated at five miles. This will give one thoufand fquare miles, or fix hundred and forty thoufand acres, as the area of its furface. Its depth is fufficient for the navigation of the largeft veffels. It contains feveral iflands; one of them, the Grand Ifle, is twenty four miles long, and from two to four miles wide.

The waters which form this lake, are colleeted from a large tract of country. All the ftreams, which arife in more than one half of Vermont, flow into it. There are feveral, which alfo fall into its ealtern fide, from the province of Canada. It is probable the rivers which flow into the weft fide, are as large, numerous, and extenfive, as thofe on the eaft. The waters therefore, from which Lake Champlain is formed, feem to be collected from a tract of country, of a larger extent, than the whole ftate of Vermont.

There are many marks and indications that the furface of this lake, was formerly thirty or forty feet higher 
higher than it is now. The rocks in feveral places appear to be marked, and ftained, with the former fuiface of the lake, many feet higher, than it has been, from its firft difcovery by Sir Samuel Champlain, in 1608 . Foffil thells, the limbs and bodies of trees, are frequently found at the depth of fifteen or twenty feet'in the earth; this is the cafe not only along the fhores, but in the low lands at the diftance of two or three miles from them. The foil in many places near the fhore, is evidently of the fame fac. titious kind, as the intervales formed by the rivers: Thefe, and other circumftances, have left no doubt in the minds of the inhabitants along the lake fhore, that the waters of it were formerly much higher, and fpread to a much greater extent, than they now are.

The operations of nature with refpect to the lake; mult have been the fame that they were in relation to the rivers. When the waters difcharged by the Itreams, amounted to fuch a collection, as to rife above the thores of the lake, they would overflow at the loweft part. There, the channel would begin; and being formed, it would become more and more deep, in the fame manner as the channel of a river. The channel which this lake found; and formed, was to the northward; into the river St. Lawrence; and through that into the ocean. When this channel, by the conftant running of the water, was worn down thirty or forty feet, the furface of the lake would naturally fubfide the fame fpace.

At prefent there is but little alteration in the height of the waters, through the year. They generally rife from about the twentieth of April until the twentieth of June. Their rife is commonly from four to fix feet, the greateft variation is not more than eight feet. The lake is early frozen round the fhores, but it is not commonly wholly fhut up with the ice, until the 
the middle of January*. Between the 6 th and the $15^{\text {th }}$ of April, the ice generally goes off; and it is not uncommon for many fquare miles of it, to difappear in one day.

The north line of Vermont paffes over the fouth part of the lake Memphremagog. This lake is about forty miles in length, and two or three miles wide. It lies chicfly in the province of Canada, and has northerly direction. The river St. Francis forms a coinmunication between the lake Memphremagog, and the river St. Liawrence. Round this lake, there is a rich foil, and a fine level country.

* When the ice is become of its greateft denfity and firmnefs; large and extenfive crácks or openings will fuddenly take place. Thefe cracks in the ice, generally run in an oblique direction, from one cape to anothen, and often to the diftance of ten or fifteen miles. . Sometimes the ice will feparate on each fide, to the diftance of five or fix feet; at other timess it will lap over, or more commonly be thrown up in ridges four or five feet: high ; and it is often broken into pieces of two or three feet diameter, all round the edges. Thefe openings often prove dangerous to the traveller. They feem to be produced, by the occafional rife and fall of the waters, in the lake; which as they cannot remove, muft operate to elevate and deprefs, and thus to bend and break, the extenfive and folid body of ice; which muft have affumed the fpherical form, which the waters had when they were firft frozen.

$$
\text { E. CHAP. }
$$




\section{H A P. IV.}

Climate - An Account of the Temperalure, Dinds, Rain, Snow, and Weaiber. The Cbange of Climate wbich bas atsended the Sultivation of the Country.

\section{THE temperàture of any particu-} lar place, depends chiefly upon, the latitude, the cultivation of the country, the elevation of the place above the adjacent lands, and its proximity to the ocean. The latitude of Vermont is between 42044 , and $45^{\circ}$ north : Much the largef part of the fate has never been cultivated: A large part of the land, is a range of mountains, much higher than the adjacent parts of the country: And the fate is from eighty to one hundred and fixty miles from the ocean.

The molt common method of determining the mean degree of heat which prevails in any part of the earth, is by thermometrical obfervations. In the years $1789,90,9$, I made a courle of nieteorological obfervations at Rutland, about the latitude of $43^{\circ} 30 \%$ The greateft height of Farenheit's thermometer during that period, was $93^{\circ} \frac{8}{2}$, on July 13 , 1791. The leaft height was 27 below 0 , on December 19, 1790. Thefe may be efteemed as near the extremes of heat and cold, in this climate. The mean beat, deduced from the whole number of obfervations, was $43^{\circ} \frac{\%}{2}$.

The temperatiure of the climate may allo be determined by oblervations of the heat which prevails in deep wells and fprings. The heat of the atmofphere, 
I...... 
The winds in Northamerica receive their general direction from the fituation of the fea coafs, mountains, and rivers. Thefe are very much from the fouthwelt to northeaft. The molt prevalent of our: winds, are either parállel with, or perpendicular to this courfe : Or rather, they are from thie northeaft, eaft, fouthwel, and-northwef. More than ore half of the winds which blow during the year, are from that quarter-which lies between the fouthweft and northweft. - The weft and northwent winds are dry, cooling, and elaftic. Thefe winds always begin at the fea coaft: Thofe from the fouth and fouthweft are more warm, moit, and relaxing. The eafterly winds feldom extend fo far from the fed coaft as Vermont; - They not only lofe their difrelfing chill and damprefs, as they advance into the country, but they feldom reach fo far as Connecticut river; and they are unknown on the "weft fide of the green mountains. - - The winds: feem to obferve fomething like a-regular courfe, during the day. At funrife there-generally feems to be a calm; about feven or eight o'clock, the winds begin to rile, which at inine or ten becomes a freflz breeze; and increafes until one or two o'clock: From about three or four, the wind decreafes until eightor nirie in the evening.; when it again becomes calm, and continues thus through the night. This general routine feems to be oblerved more generally in the latter part of winter, and in the fpring, than at: other times of the year. But there are times in thofe feafons of the year, when the wind rages without much intermifion for two or three days tod gether.

A general table of their directions at differend places upon the continent, will give the beft vitws of their comparative courfes. 


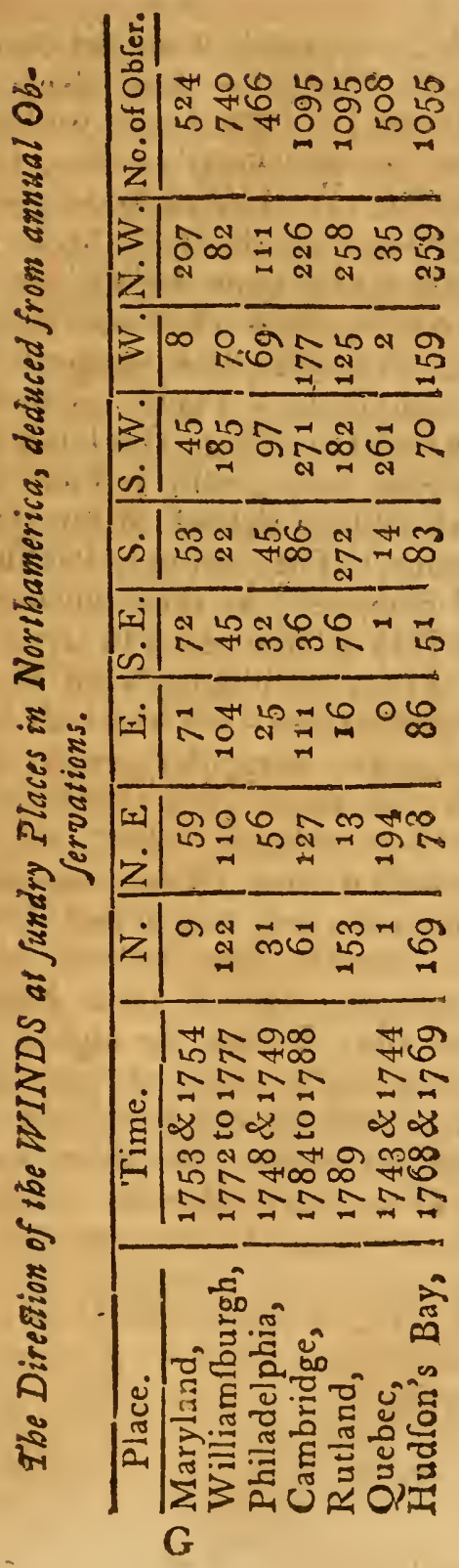


The quantity of rain which falls at thofe places in Northamerica where meteorological obfervations have been made, has been found to be more than double to that which generally falls in the fame latitude in Europe. We cannot well account for this, without fuppofing that the immenfe forefts of America, fupply a larger quantity of water for the formation of clouds, than the more cultivated countries of Europe. Many parts of America do however, fuffer feverely by drought: This is very feldom the cafe in Vermont. The lands are naturally moift, the mountains fupply water for regular rains, and the heat of the fun is not fo intenfe as fuddenly to difperfe the vapours, dry up the waters, or parch the land. Thefe kinds of obfervations will be reduced to the fmalleft compafs, and give the moft complete comparative view, by exhibiting thers in the form of a general Table. 


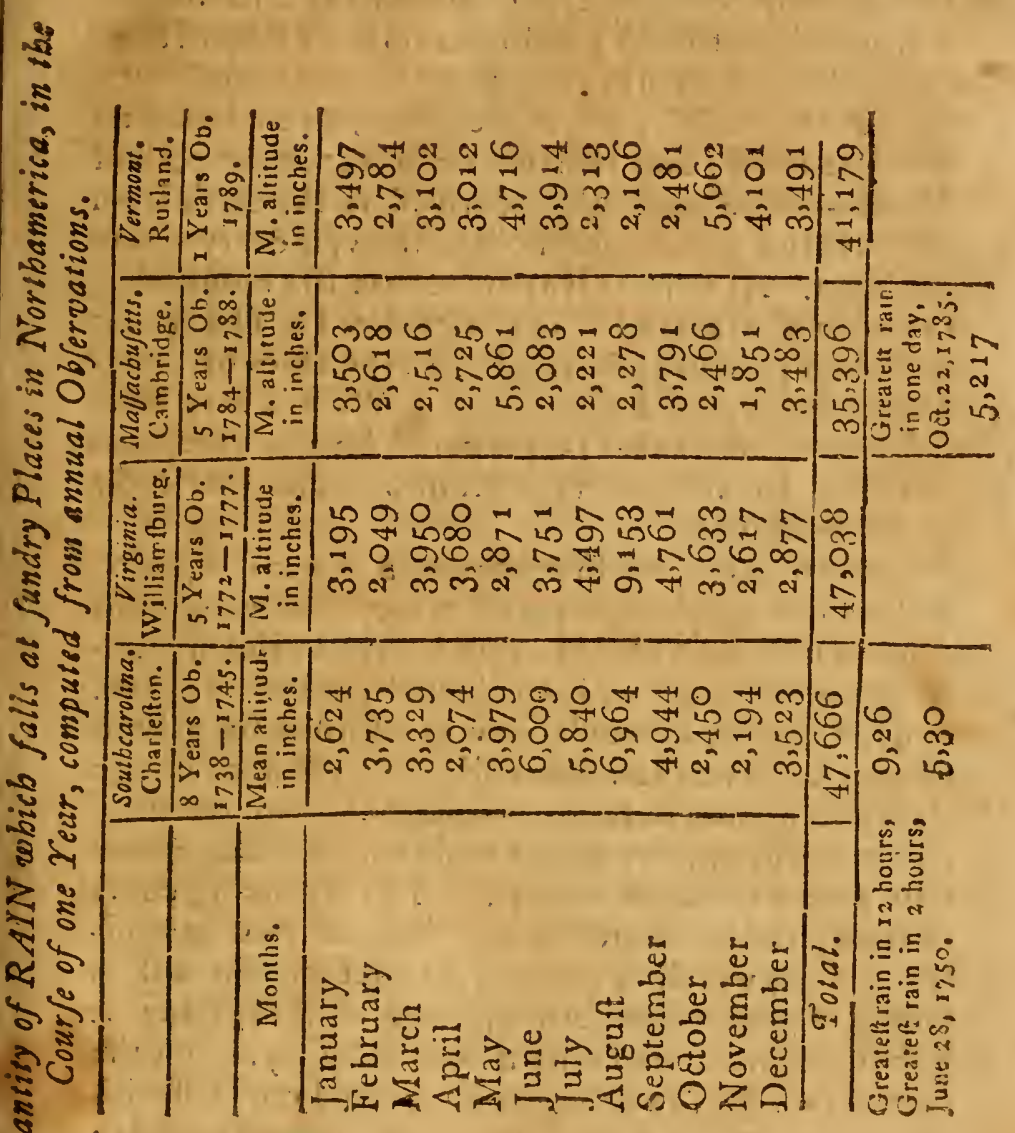

During 
During three months in the year, this part of $\mathrm{A}$. merica is covered with fnow. On the mountains the fnow is generally from two and an half to four and an half feet deep; and does not go off until after the middle of April. In the lower grounds, the fnow for the moft part, is from one, to two and an half feet decp; and remains until about the 2 oth of March.-The advantage derived to the earth from the quantity and duration of the fnow, is every where apparent. As foon as it is melted on the mountains, the earth appears to be greatly fertilized: The fpring comes on immediately; and the vegetables of every kind are green, and flourithing. . With a very little cultivation, the earth is prepared for the reception of the feed; and the vegetation becomes extremely quick and rapid.

The effects being fo apparent, a general opinion feems to have taken place, that the fnow communicates to the earth fome nitrous falts or enriching fubftance which tends to increafe its fertility. In Feb. 1791, I melted as much fnow as afforded fix gallons of water. The fnow was collected as it was falling : Being evaporated there remained eleven grains of calcarious earth, five grains of an oily fubftance, and two grains of faline matter. The fertilizing effect of fnow, cannot therefore be derived from any nitrous falts, which it receives or contains when it is falling through the atmofphere. Sufpecting it might acquire fome faline mixtures by laying on the earth, Jan. 30, 1792, in an open field covered with grafs, I collected as much of the fnow which lays next to the earth, as produced fix gallons of water. This now fpread over an area of fixteen fquare feet, and had lain upon the ground fifty nine days. Upon cvaporating the water there was not more faline matter, or calcarious earth, than in the former experiment; but a much larger quantity of oily fubftance. The oil was of a dark brown colour, not inflamma ble, 
ble, and weighed four pennyweights and nine grains, troy weight. From the former experiment, it appears that the biggeft part of this oily matter accrued to the fnow after it had fallen upon the earth : And to this oily fubftance, is probably to be imputed that dirty or footy appearance, which the fnow is generally obferved to have, after it has begun to thaw. If the fnow which I removed contained the fame quantity of oil as that which I examined, a confiderable nutriment might be preferved to the earth from this caufe. The depth of the fnow was thirty inches: The depth of that quantity which I collected to melt, as nearly as I could determine, was three inches. This will give two ounces, three pennyweights and eighteen grains, as the quantity of mucilaginous matter, which would have defcended upon fixteen fquare feet of the earth, from the quantity of fnow that was then upon the ground.

While the fnow thus prevents all wafte from the furface of the earth, it performs another and more important office, that of preferving its internal heat. The internal parts of the earth through the territory of Vermont, are heated to about the forty fourth degree of Farenheit's thermometer. When the heat of the atmolphere is greater than this, a part of that heat will flow into the earth, and thus the heat of the earth will be increafed. When the heat of the atmofphere is lefs than forty four degree's, the heat will flow out of the earth into the atmorphere, and in this way the internal parts of the earth will be lofing their heat, or becoming colder. This is the cafe during the winter months; or rather, from the middle of October, to the beginning of April. Hence the furface of the earth when expofed to the atmofphere, becomes frozen to a greater or lefs depth, according to the degree and duration of the cold. The fnow tends very much to prevent this. By covering over the furface of the ground a confiderable depth, 
the fnow by its nature and colour, prevents the in ternal heat of the carth from flowing into the colder atmofphere, and the atmolphere from coming into contact with the earth. In this way while the earth is covered with a deep fnow, its heat is preferved, and the furface, in the coldeft weather, is kept warm. To afcertain to what degree the heat of the earth was affected, by the quantity of fnow that lay upon it, on Jan. 14, $179^{1}$ (an extreme cold winter) I dug through the frozen furface in a plain open field, where the fnow had been driven away by the wind, and found the ground was frozen to the depth of three feet and five inches. In the woods, where the fnow was three feet deep, I found on the fame day the heat of the earth, fix inches below the furface, was thirty nine degrees. The furface of the earth liad been frozen to this depth, before it was covered with fnow. The froft was not only extracted, but the furface of the earth was heated feven degrees above the freezing point, in confequence of the fnow with which it was covered.

This will help us to account for the beneficial effects, which are derived from the fnow, in all cold climates. Different degrees of heat are neceffary, for the prefervation and growth of different vegetables. None of them grow, when they are frozen; and moft of them will perifh when the cold at their roots is very fevere. A thick covering of fnow prevents thefe effects. The earth is kept open, and the roots of the vegetables are preferved comparatively warm. The fnow is continually melting at the furface of the earth: It moiltens, and cnriches the foil ; keeps off the froft and wind, and prevents all evaporation from the furface of the earth. The earth thus prepared by heat and moifture, and a collection of all its effluvia, is in a fit tate for that fudden and rapid vegetation, which takes place in ali cold climates, immediately upon the melting of the fnow. 
The weather is generally fair, in the winter; and often, with an hazy atmolphere. The fnows are frequent, but they generally come in fmall quantities, and are over in one or two hours: They are not attended with high winds, or heavy ftorms; but they come from all points of the compafs, except the eaft; very frequently from the weft, and northweft. Hail is not uncommon in the winter, but rain is not frequent. - About the middle of March the fpring commences. The winds and weather are then very unfettled until the beginning of April. In April and May the weather becomes mild and pleafant, attended with frequent Thowers.-In the fummer months the weather is generally fair, clear and fettled. The wirids are moftly from the fouth, and fouthweft; the heat in the middle of the day is often very uncomfortable, but the nights are almoft ever cool and pleafant.-From the beginning of September, until the middle of October, we have commonly the moft agreeable feafon, with moderate weftesly winds, and a clear fky. - The latter part of October and November, are generally cold, wet and uncomfortable; attcnded with frequent rains, fome fnow and high winds.

Thunder and lightning are common in the months of May, June, July and Augun ; but feldom in the other months. The Aurora Borealis is the inoft common in the months of March, September and October; but it is not unufual at other times of the year. Heavy and long ftorms of fnow, or rain, are fcarcely ever known: But fudden and violent whirlo winds or hurricanes fometimes arife, and do much damage in the fall; but we feldom receive any injury from the hail. - Annual courles of meteorolog. ical obfervations properly reduced, will afford the moft complete information of the weather, and me. seors, in the different parts of Northamerica. 


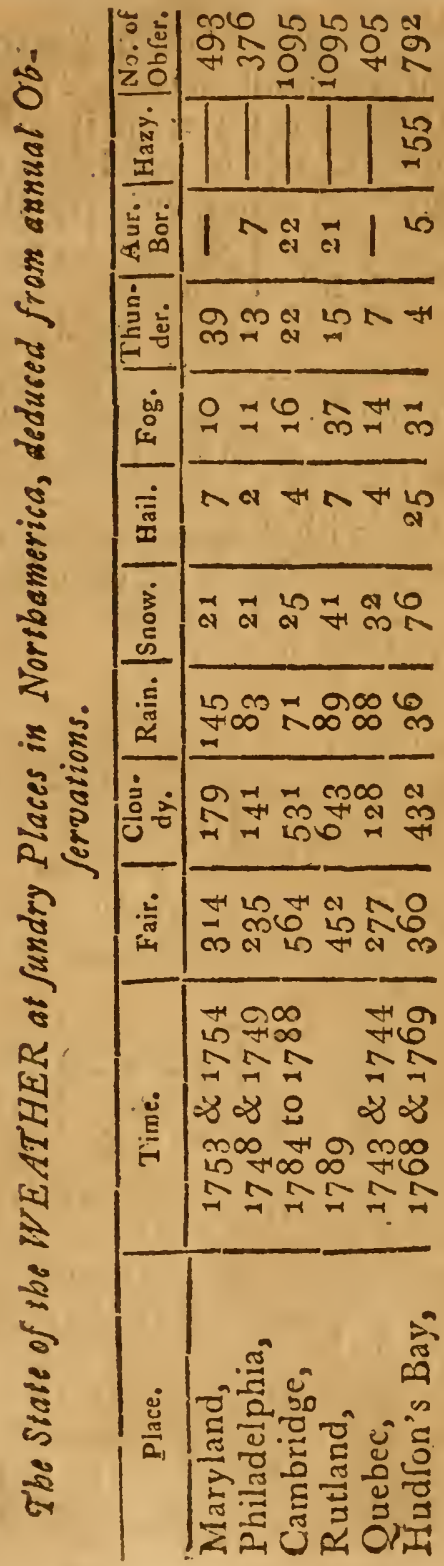


The above accounts are defigned to exhibit a juft view of our climate. But inftead of remaining fixed and fettled, the climate is perpetually changing and altering, in all its circumftances and affections : And this change infead of being fo flow and gradual, as to be a matter of doubt, is fo rapid and conftant, that it is the fubject of common obfervation and experience. It has been obferved in every part of the United States; but is moft of all fenfible and apparent in a new country, which is fuddenly changing from a ftate of vaft uncultivated wildernefs, to that of numerous fettlements, and extenfive improvements. - When the fettlers move into a new townfhip, their firft bufinels is to cut down the trees, clear up the lands, and fow them with grain. The earth is no fooner laid open to the influence of the fun and winds, than the effects of cultivation begin to appear. The furface of the earth becomes more warm and dry. As the fettlements increafe, thefe effects become more general, and extenfive: The cold decreafes, the earth and air become more warm; and the whole temperature of the climate, becomes more equal, uniform and moderate. At the fame time the lands and roads become more dry and hard: The ftagnant waters difappear, fmall ftreams and riv-ulets dry up, and the redundant waters are carried. off. The number and quantity of the frows decreafe; the winds receive new directions, and the weather and feafons become much altered. Thefe changes every where attend the cultivation of the country ; and have formed a remarkable change of climate in thofe ftates, which have been long fettled.

In this change of climate, the firft effect which is generally obferved, is an alteration in the temperature. The cold of the winters decreafe; the rivers are not frozen fo foon, fo thick, or fo long, as they formerly were; and the effects of extreme cold, in cvery refpect, appear to be diminithed. A remark. 
able change of this kind, has been obferved in all the fettled parts of Northamerica. The bays and rivers in Newengland, are not frozen fo hard, or fo long, as they were at the firft fettlement of the country.* At the firft fettlement of Philadelphia, the river Lelaware was commonly covered with ice, about the middle of November, old Atyle.t It is not now commonly covered with ice, until the firft week in January. Similar obfervations have been made with regard to the ice in Hudfon's river. The baron Labontau gave this account of the river St. Lawrence, at Quebec, in $16 \mathrm{go}$ : "I put to fea the 20 th of November, new ftyle, the like of which was never feen in that place before. The ice had covered the river on the $13^{\text {th }}$ and $14^{\text {th }}$ of November, but was carried off by a fudden thaw." $\|$ The river is not frozen over now until the latter end of December, or the beginning of January. The ancient people at Quebec, in 1749, informed $\mathrm{Mr}$. Kalm, that the winters in Canada were formerly much colder, than they were then. $\$$ Similar obfervations have been made in almoft every part of Northameri$c a$, where fettlements and cultivation have taken place.

Although the general effect has been every where apparent, it is not an eafy thing to afcertain the dsgree, to which the temperature has changed, in any particular place. When our anceftors firft came into America, thermometers were not invented : And they have not left us any accurate meteorological remarks or obfervations, from which we can determine the exact degree of cold, which prevailed in their times. Upon looking over the moft ancient. writers of Newengland, the only account I have found,

* Newengland's Profpect, by W. Wood; wrot in $1633, p .4$.

+ Kalm's Travels, Vol. 1. p. 410.

\# Smith's Hiftory of Newyork.

II Voyages to Northamerica, p. 165.

$\$$ Kalm's Travels, Vol. II. P. $3^{82}$. 
found, which will afford any diftinet information upon this fubject, is the following paffage ; referring to years previous to $16_{33}$. "The extremity of. this cold weather lafteth but for two months, or ten weeks, beginning in December, and breaking up the tenth day of February (21ft new ftile) which hath become a paffage very remarkable, that for ten or a dozen years, the weather hath held himfelf to his day, unlocking his icy bays and rivers, which are never frozen again the fame year, except there be fome fmall froft until the middle of March."* The winter is lefs fevere now in feveral refpects : The extremity of the cold weather does not come on fo foon by feveral weeks; the bays at Bofton, inftead of being annually covered with ice, are but feldom frozen to this degree; and they do not continue in this ftate a longer time than eight or ten days. In the year. 1782 , the harbour between Bofton and Charleftown was frozen to fuch a degree, that horfes and fleighs paffed over the ice, for five or fix days. This was the beginning of fuch an effect, as that which is mentioned in the ancient account. The ice became fixed and permanent on February 2 ; and continued in this fate until February 10. During that time I found the loweft degree of Farenheit's thermometer to be $-9^{\circ}$; the greateft degree was $28^{\circ}$; and the mean heat was $13^{\circ}$. It may be prefumed therefore, that the freezing of the bays of which Wood fpeaks, could not have taken place, or continued, in a lefs degree of heat than this. This will give us 13 degrees of Farenheit's thermometer, as the mean heat which took place during eight or ten weeks of the winter, fo far back as the year 1630 . By the meteorological obfervations which I made in the Univerfity at Cambridge for feven years, from 1780 to 1788 , I found the inean heat in the month of December was $29^{\circ} 4^{\prime}$; in January it was $22^{\circ} 5^{\prime}$;

2.Wood's Profpet, p. 4, 


\section{THE NATURAL AND CIVIL}

and in February it was $23^{\circ} 9^{\prime}$. The Te numbers exprefs the prefent temperature of the winter at Bofton. If this computation be admitted, the change of temperature in the winter, at Bofton, from the year 1630 to the year 1788 , mult have been from ten to twelve degrees.

A permanent alteration in the temperature of the ciimate or atmofphere, fuppofes an alteration equally great and permianent, in the heat of the earth. Whether the heat of the earth is thus affected by cultivation, and what will be its effects, I endeavourcd to afcertain in the following manner. On the $23^{d}$ of May, 1789, I funk a thermometer to the depth of ten inches below the furface of the earth, Upon repeated trials the quickGlver flood at fifty degrees: This was in a level apen field, ufed for pafture or grazing, and fully expofed to the fun. The fame experiment was then made in the woods, where the furface of the earth was covered with trees, and never had been cultivated. To afcertain the gradual increafe of heat at each place, the obfervations were often repeated. The refult was as follows.

\begin{tabular}{|c|c|c|c|c|}
\hline Time. & & $\begin{array}{l}\text { Heat in the } \\
\text { Pafure. }\end{array}$ & $\begin{array}{l}\text { Heat in the } \\
\text { Woors. }\end{array}$ & $\begin{array}{l}\text { Differ- } \\
\text { ence. }\end{array}$ \\
\hline$\widehat{\text { Say }}$ & 23 & $50^{\prime \prime}$ & $4^{6^{\circ}}$ & $\overline{60}$ \\
\hline une & 28 & 6 & $\begin{array}{l}4^{8} \\
51\end{array}$ & $\begin{array}{r}9 \\
13\end{array}$ \\
\hline & 27 & 62 & 51 & 11 \\
\hline uly & 16 & 62 & 51 & 11 \\
\hline Lun & 30 & $65^{\frac{1}{2}}$ & $55 \frac{1}{2}$ & 10 \\
\hline & 31 & $59 \frac{1}{2}$ & \begin{tabular}{ll|l}
5 & 55 \\
55 &
\end{tabular} & 10 \\
\hline eptember & & $59 \frac{1}{2}$ & 55 & $\begin{array}{l}4 \sqrt{i} \\
4 \frac{5}{5}\end{array}$ \\
\hline 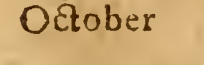 & & $59 \frac{1}{2}$ & 55 & $4 \frac{7}{2}$ \\
\hline November & & 43 & $\begin{array}{l}49 \\
43 \\
43 \frac{1}{3}\end{array}$ & ó \\
\hline & & & & The \\
\hline
\end{tabular}


The effect of cultivation with regaid to the beat of the earth, fo far as it can be collected from thefe experiments, appears to be this : Expofing the land to the full force of the folar rays in this latitude, will produce an heat at the depth of ten inches below the furface, ten or eleven degrees greater than that which prevails in the uncultivated parts of the country; and this effect continues while the folar rays are fufficient to increafe the heat of the earth. This additional heat in the earth, will be fufficient to produce the fame alteration in the temperature of the air; for whatever degree of heat prevails in the earth, nearly the fame will be communicated to the lower parts of the atmofphere. . Thus the earth and the air, in the cultivated parts of the country, are heated in conlequence of their cultivation, ten or eleven degrees more, than they were in their uncultivated ftate: It fhould feem from the fe obfervations that the effect, or the degree of heat produced by cultivation, is the fame with the change of climate, that has taken place in the eaftern part of Mallachufetts.

Another remarkable effect which makes part of the change of climate, and, always attends the cultivation of the country, is an alteration in the moifture or wetnels of the earth. As the furface of the earth becomes more warm, it becomes more dry and hard, and the ftagnant waters difappear. Alterations of this kind, have been common, and great, in all the ancient fettlements in the United States. Many of the fmall ftreams and brooks are dried up: Mills, which at the firft fettlement of the country, were plentifully fupplied with water from fmall riv ers, have ceafed to be ufeful. Miry places, and large fwamps, are become among the richeft of our arable lands. - In the new fettlements, the change is effected in two or three years : Fields of corn and wheat are attended with the molt rapid vegetation, 
and the greateft increafe, in lands, where the waters five or fix years ago, were ftagnant, and in fuch quantities as to be fpread over the largeft part of the ground. One of the firft effects of cultivation is the difperfion of thefe waters, and a change in the foil, from the appearance of a fwamp, to that of a dry and fertile field.

There are two ways in which cultivation opcrates, to produce this effect. By the cutting down of the trees, the difperfion of a vaft quantity of fluid, emitted by their evaporation, is prevented ; and by laying the lands open to the influence of the fun and winds, the evaporation of the ftagnant waters is greatly promoted. - The effect of the firft, from experiments which will be related when the vegetable productions are confidered, may be eftimated at three thoufand and eight hundred gallons of water thrown off from the trees on one acre, in the fpace of twelve hours, in hot weather. To afcertain the effect which might arife from the latter, on June 27 th, 1789 , a fair, calm, and hot day, I placed a china faucer on the ground in the woods, where it was covered from the folar rays by the trees, the leaves of which at the height of ten or twelve feet, were very thick. Another faucer in all refpects fimilar to this, was placed on the ground in an open field adjoining, where it was fully expoled to the wind and fun. I poured into each of them equal quantities of water : at the end of three hours the evaporation from the latter, was to that from the former as Gx, eight to one.-With regard then to the moifture or wetnefs of the country, it appears that fettlement and cultivation will be fufficient to prevent the difcharge of three thoufand and eight hundred gallons of water, over one acre of land, in twelve hours, during the hot u'eather $^{\prime}$ and at the time to effect the difperfion of fix, eight times as much water from the furface of the earth, as would have been difperfed in its unculsivated 
uncultivated ftate. If we may judge upon a mattes which cannot be reduced to exact calculation, it fhould feem that the caufe was here equal to the effect.

A change in the climate hath alfo been manifeft in the apparent decreafe of the fnow; in all the ancient cultivated parts of the United States. Whether there has been any alteration in the annual quantity of rain in any part of America, we cannot de. termine, for want of meteorological obfervations ; but a great decreafe of fnow has been obferved in all the ancient fettlements. At the firft fettlement of Newengland, the earth was generally covered with fnow for more than three months in the year. It began to fall in large quantities by the firft of. December, and feldom went off until fome time in March. This is yet the cafe in the inland and mountainous parts of the country. The fnow cov. ers them for three months, and is foarcely ever carried off by a thaw until the fpring comes on. In thofe parts of the country which have been long fettled and cultivated, the frows have been declining for many years. They are neither fo frequent, deep, or of fo long continuance, as they were formerly: And they are yet declining very faft in their number, quantity, and duration. This event is derived from the change of temperature, which has taken place in the atmolphere; and probably will keep pace exactly with it. There has alfo been an apparent alteration in the direction of the winds. The prevalency and extent of the wefterly winds, feem to be abating: Or rather the eafterly winds are certainly increafing in their frequency and extent. Thefe winds are now very frequent in the fpring, in all that part of the country, which lies within fixty or feventy miles of the fea coaft. Half a century ago, the eafterly winds feldom reached farther than thirty or forty miles from the fea thore. They have 
now advanced as far as the mountains, which are generally eighty or an hundred miles from the ocean. As the country becomies fettled and cleared, they are found to advance more and more, into the internal parts of the countrý. - It can hardly be doubt. ed; but that this event is owing to the increafing cultivation of the country. As the woods are cut down, the earth and atmofphere become more heated than the ocean : The direction of the winds will of courfe be from the fea; towards the land. A the country becomes more fettled and cleared, it is probable thefe winds will continue to advance furtlier towards the weft:

The fame caufes which produce a change in the heat of the earth, in its wetriefs, in the fnow and winds, will produce as great a change in the weather. and feafons. While the ftate of a country remain unaltered, the general courfe and appearance of nature will be the fame, from one age to another. Summer and winter, fpring and fall, the productions of the earth, the ftate of the air and weather, will be fubject to but little annual alteration or change. But when the whole face and ftate of a country are changing, the weather and feafons will alfo change. with them. - This is an event that has already taken place in the molt ancient and cultivated parts of $A$ merica. When our anceftors firft came into New. england, the feafons, and weather were uniform and regular. The winter fet in about the beginning of December, old fyle, and continued until the middle of February. During that time the weather was generally fair, and cold, and without much change. Towards the end of February the winter generally broke up. When the fpring came on, it came on at unce; without repeated and fudden changes from he.' $10 \mathrm{cold}$, and from cold to heat. The.fummer was cremely hot and fultry, for a month or fix week it it was of a fhort duration. The autumn commenced 
commenced about the beginning of September; and the harveft of all kinds was gathered by the end of that month. - A very different fate of things now takes place, in all that part of Newengland, which has been long fettled. The feafons are much chang$e d$, and the wexther is become more variable and uncertain. The winter is intermixed with great and fudden thaws, and is become much fhorter. The changes of weather and temperature, are great and common in the fpring; and at that feafon there is - generally ar unfortunate fluctuation between heat and cold, greatly unfavourable to vegetation, and the fruits of the earth. The fummers are become more moderate in refpect to the extreme heat of a few weeks; but they are of a much longer duration. The autumn commences, and ends, much later than formerly: The harveft is not frniffed until the firf week of November, and the feverity of winter does not commonly take place, until the latter end of Decernber? But the whole courfe of the weather is become more uncertairi variable and fluctuating than it was in the uncultivated ftate of the country. It is in thefe particulars, the change that has taken place in the lieat of the earth, in its wetnefs, in tie frow, winds, weather and eafons, that the change of climate in Northamerica has principally appear. ed. That this change of climate is much connecled with; and greeutly accelcrated by the cultivation of the country, cannot Be, doubted. But whether this caute is fufficient to account for all the phenomena, which have atterded the change of climate in the various parts of the carth, fecms to be uncertan.

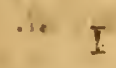

EIA 


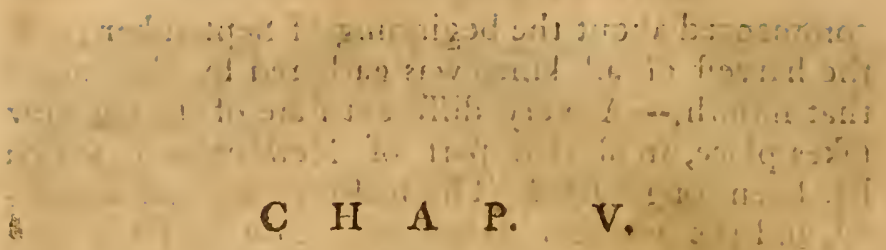

Vegetable PROD Uctions.-Foreft Trees, efculent and medicinal Vegetables: Remarks on the Magnitude, Number, Age, Evaporation, Emifion of Air, Heat, and Effect of the Trees.

W. HEN the Europeans firft took poffeffion of Northamerica, it was one continued foreft, the greateft upon the earth. : The country was every where covered with woods, not planted by the hand of man; but derived from, and ancient as the powers of nature. The great variety of plants and flowers, the immenfe numbers, dimenfions, and kinds of trees, which fpread over the hills, valleys, and mountains, prefented to the eye, a moft magnificent and boundlefs profpect. This is till the cafe with the uncultivated parts of the country.

Much the largeft part of Vermont is yet in the ftate, in which nature placed it. Uncultivated by the hand of man, it prefents to our view a vaft tract of woods, abounding with trees, plants, and flowers, almont infinite in number, and of the moft various fpecies and kinds. It would be the employment of snany years, to form a complete catalogue of them. 1 thall not attempt to enumerate any, but thofe which are the moft common and ufeful. 


\section{FOREST T RE E.}

The $T_{R E E S}$ which are the moft large and common are the

White pine: Pinis frobus.

Yellow pine. Pinus pinea...

Pitch pine. Pinus teda:

Larch. Pinus larix.

Hemlock. Pinus abies.

White fpruce. $\}$ Pinus canadenfis:

Fir. Pinus balfainea.

White maple. Acer negundo.

Red maple. Acer rubrum.

Black maple. Acer Saccbarinum.

White beech.
Red beech, Fagus fylvatica.

White alh. Fraxinus excelfior.

Black afh. Fraxinus americana.

White birch. Betula alba.

Black birch. Betula nigra.

Red or yellow birch. Betula lenta.

Alder. Betula alnus.

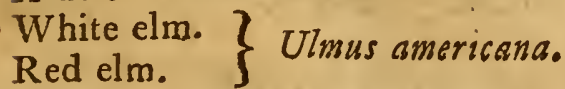

Black oak. Quercus nigra.

White oak. Quercus alba.

Red oak. Quercus rubra.

Che[nut oak. Quercus prinus.

White hiccory, or Walnut. Fuglans alba.

Shagbark. Fuglans alba, cortice fquamoso.

Butternut. Fuglans alba, cortice catbartica.

Chefnut. Fagus caftanea.

Buttonwood. Plantanus occidentaiis.

Baffwood, or lime tree. Tilia americana.

Hornbeam. Carpinus betulus. 
Wild cherry, feveral fpecies.

Saffafras. Laurus fofjafras.

White cedar. Thuja occidentalis.

Red cedar. Funiperus virginiand.

White poplar, or Afpen. Populus trensula. : : 0.8

Black poplar, or Balfam. Populus nigra.

Red willow. Salix.

White willow. Salix alba.

Hackmatack. -

\section{E S C U L E N T.}

The following are fmall trees, fhrubs, or vines; val, uable on account of their falubrious and plealan fruit.

Red plumb.
Yellow plumb. Prunus fylveftris.

Thorn plumb.

Black cherry.

Red cherry.

Choke cherry.

Cerajus jylveftris.

Juniper. Funiperus fabina.

Hazlenut. Corylus avellana.

Black currant. Ribes nigrum.

Wild goofeberry. Ribes glofuicria.

TWhortleberry.

Bilberry.

Blueberry:

Chokeberry.

Partridgeberry. Arbutus viricis.

Pigeonberry'. Ciffus.

Barberry. Berberis vulgaris.

Mulberry. Morus nigra.

Black grape. Vitis labrufca.

Fox grape. Vitis vulpina.

Black ralpberry. Rubus ideus.

Red rafpberry. Rubus canadenfis.

Upright blackberry. Rubus fruticofus.

Running 
Running blackberrỳ. Rubus moluccanus: Brambleberry. Rubus occiatentalis.

Cranberry.

Bufh cranberry.

\} Vaccinium oxycoccos,

Strawberry. Fragaria vefica.

Dewberry. Rubus cafíus.

Cloudberry. Rubus cbamemorus.

Thefe fruits are in great abundance in the uncultivated parts of the country ; but thcy feem to arrive to their highef perfection of numbers, magnitude, and richnefs, in the new fields and plantations. There are other vegetables which are alfo efculens, and valuable, chiefly on account of their roots, or feeds. Among thefe are the

Artichoke. Heliantbus tuberofus.

Ground nut. Glicine apios.

$\left.\begin{array}{l}\text { Long potatoe. } \\ \text { Red potatoe. }\end{array}\right\}$ Conzolvulasbataias.

Wild leek.

Wild onion.

Wild oat. Zizania aquatics.

Wild pea.

Wild hop. Humulus lupulus. Indian cucumber. Medeola.

\section{E D I C.I N A L.}

Many of the vegetables which are indigenous to this part of America, are applied to medicinal purpofes. Of this nature are the

Bitter [weet. Solanum.

Angelica. Angelica fylveftris.

Black elder. Sambucus nigra.

Red elder. Viburnum opulus.

Sarfaparilla. Aralia.

Pettymorrel. Aralia nigra.

Solomon's feal. Convallaria. 
Maiden hair. Adiantbus pedatus. Arfmart. Polygonum fagiltatum. Wild rofe. Rofa fylueftris.

Golden thread. Nigella.

Mallow. Malva rotundifolia.

Marfhmallow. Altbea.

Lobelia, feveral fpecies.

Senna. Cafja liguftrina.

Clivers. Gallium. Jpuriuss.

Blue flag. Iris.

Sweet flàg. Acorus.

Skunk cabbage. Arum americansm.

Garget. Pbjelolecca decandra...

Blood root. Sanguinaria.

Pond lily. Nymphea.

Elecampane. Inula.

Black fnake root. AETea racemsofa.

Seneca fnake root. Polygala fenega.

Pleurify root. Afclepios desumbens.

Liquorifh root.

Dragon root. Amur.

Ginfeng. Panax trifolium.

Ginfeng was formerly efteemed a plant indigenous only to China and Tartary. In 1720, it was difcovered by the Jefuit Lafican, in the forefts of Canada ; and in 1750; it was found in the weftern parts of Newengland. It grows in great plenty and perfection, in Vermont. The root has many virtues; but we do not find them to be fo extraordinary, as the Chinefe have reprefented. It was a valuable article in the commerce of Canada in the year $175^{2}$, and large quantities were purchafed in this ftate but a few years ago; an injudicious method of collecting, curing, and packing it; has greatly injured its reputation; this, with the large quantities in which it was exported, have nearly deftroyed the fale. 
To this account of medicinal plants; it may not be improper to fubjoin thofe, which in their natural ftate, are found to operate as poifons; the moft of which, by proper preparations, become valuable medicines. Of thefe we have the

Thorn apple. Datura Aramonium.

Henbane." Hyofiyamus niger.

Nighthade. Solanum nigrum.

Ivy. Hedera belix.

Creeping ivy. Rhus radicans.

Swànp fumach. "Rbus toxicodendrum.

Baneberry. AEZa Spicata.

White hellebore. Veratrum album.

In addition to thefe, there is a great variety of plants and flowers, the names and virtues of which are unknown. Some of our vegetables deferve a particular defcription, on account of their uncommon properties : Thus, the Bayberry (mirica cerifera) is diftinguifhed by a fine perfume, and a delicate green wax. The Prickly Afh is valuable for its uncormon aromatic properties. The Witch $\mathrm{Ha}$ zel (banlamelis) is endowed with the fingular property of putting forth its bloffoms, after the froft has deftroyed its leaves. The Indian Hemp (afclepias) may be wrought into a fine, and frong thread. The Silk Grafs another fpecies of the afclepios, contains a fine foft down, which may be carded and fpun in to an excellent wickyarn. The berries of the common Sumach (rbus) are ufed to great advantage in medicinal applications, and in feveral kinds of dyes. It would be a very ufeful, but a laborious employment, for the botanifts to give to the world an enumeration, and feientific defcription of our indigenous vegetables. The Flora Americana, would be the moft valuable addition, that could be made to the works of the celebrated Linneus : But it cannos be completed without the united affiftance of wealth $x$ genius, time, and labour.

To 
To this imperfect catalogue of our vegetables, Thall add fome remarks on the magnitude, number; age, evaporation, emiffion of air, heat; and effect of the Trees.

MAGNITUDE. - The magnitude to which a tree will arrive, depends upon the nature of the tree, and of the foil. The following are the dimentions of fuch trees as are efteemed laige ones of their kind, in this part of America. They do not denote the greateft, which nature has produced of their particular fpecies, ${ }^{*}$ but the greateft of thofe which are to be found in molt of ocir towns.

Pine;

Maple;

Buttonwood;

Elm,

Hemlock,

Oak,

Baffwood;

Afth,

Birch,

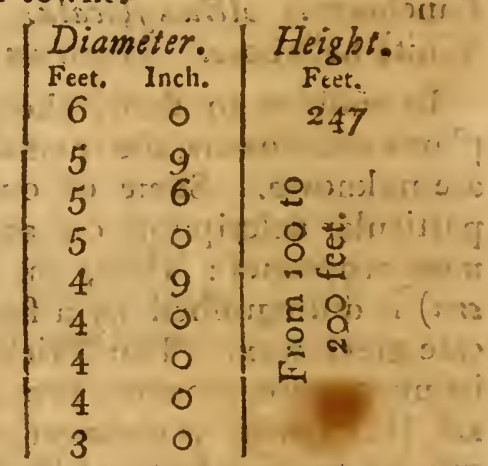

NuMBER. - The number or thicknefs of the trees, feems to depend chiefly on the richnefs of the foil. In fome parts of the country they are fo thick, that it is with difficulty we can ride among them. In other places, they have refolved themfelves into trees of large dimenfions, which are generally at the diftance of eight or ten feet from each other. On one acre, the number of the trees, is commonly from one hundred and fifty to fix hundred and fifty; va. rying in their number, according to the richnefs of the foil, and the dimenfions the trees hare attairied. Entipating a cord to be four feet in height, and width; and

* A white pine was cut at Dunftable in Newhamplaire, in 3735 , the diameter of which was feven feet, eight inches.

$$
\text { Douglafis Suininary, Vol. II. p. } 53 .
$$


and eight feet in length, the quantity of wood which is generally found on one acre, is from fifty to two hundred cords: Where the large pines abound, the quantity of wood is much larger than what is here ftated; but thefe trees are never mealured as cord wood, but always applied to other purpofes.

AGE.- There is a circumftance attending the growth of trees, which ferves to denote their age, with great accuracy. The body of a tree does not increafe by an univerfal expanfion of all its internal parts, but by additional coats of new wood: And thefe are formed every year, by the fap which runs between the bark, and the old wood. When a tree is cut down, this procefs of nature becomes apparent in the number of parallel circles, or concentric rings, which fpread from the centre to the circumference of the tree. In many obfervations made by others, and by myfelf, upon trees whofe ages were known; the number of thefe circles was found to agree exactly with the age of the tree.-By this method of computation, I have always found the pine to be the moft aged tree of our foreft, feveral of which were between three hundred and fifty and four hundred years of age. The largeft trees of other fpecies, are generally between two and three hundred years. In the more adranced periods of vegetable life, this method of computation often fails : The decays of nature generally begin in the central, which are the moft aged parts. From them, the mortification gradually extends to others; and thus, the internal parts of the tree, die in the fame order in which they were produced; the progrefs of death, regularly and fteadily following the fame order and courle, which had been obferved in the progrels of life. In this fate of a tree, no computation can be made of its age: But it feems moft probable; that the time of its natural increafe and decreafe, are $x_{i}$ arly the fame; and that the natural period of vegK etable 
etable life, is double to that, which the tree has ata tained, when it firft begins to decay at the heart.

EvAPORATION.-Befides the growth, there are other proceffes carried on by nature in vegetables, of which we have no fufpicion, until their effects become apparent. This is the cafe with the evaporation which takes place from the woods, during the fummer months. - Every tree, plant, and vegetable, is then pouring into the atmofphere, an amazing quantity of fluid.- On the 12 th of June, 1789 , I put the end of one of the limbs of a Tmall maple tree, into a bottle containing about one pint. That part of the limb which was within the bottle, contained two leaves, and one or two buds. The mouth of the bottle was ftopped up with beefwax, that no vapour might efcape. In five or fix minutes, the infide of the bottle was clouded, with a very fine vapour; and in about half an hour, Imall drops began to collect on the fides, and run down to the bottom. At the end of fix hours, 1 weighed the water which had been collected in the bottle during that time, and found it amounted to fixteen grains, troy weight.- The tree on which this experiment was made, was eight inches and an half in diamter, and thirty feet in height. To make an eftimate of the quantity of water, thrown off from this tree into the atmofphere, in a given portion of time, I endeavoured to afcertain the number of leaves which it contained. With this view (after I had made fome other experiments) I had the tree cut down; and was at the pains to count the leaves, which it contained : The whole number amounted to twenty one thoufand one hundred and ninety two: Admitting the evaporation to be the fame from the other leaves of the tree, as it was from thofe on which the experiment was made, the quantity of water thrown off from this tree in the lpace of twelve hours, would be three hundred and thirty nine thoufand and feventy two grains. 
grains.-Upon examining the number and dimen. fions of the trees, which covered the ground where I made the experiment, I think it would be a moderate computation, to eftimate them as equal both in magnitude and extent, on every fquare rod, to four fuch trees as that which $I$ had examined. This will give fix hundred and forty fuch trees, for the quantity of wood contained on one acre. This eftimation is lefs than the quantity of wood, which is generally found upon one acre of land, in this part of America.-The weight of one pint of water, is one pound avoirdupoife, or feven thoufand grains, troy weight; and eight fuch pints make one gallon. Making the calculation upon thefe principles, it will be found that from one acre of land thus covered with trees, three thoufand eight hundred and feventy five gallons of water are thrown off and difperfed in the atmofphere, in the fpace of twelve hours.

This computation, will not appear extravagant to thofe, who have feen the great quantity of juice, which naturally flows out of fome of our trees, wheis they are tapped in the fpring. A man much employed in making maple fugar, found that for twen ty one days together, one of the maple trees which he tended, difcharged feven gallons and an half eacis day. A large birch which was tapped in the fpring, ran at the rate of five gallons an hour, when firlt tapped; and during the feafon of the running of the fap, it difcharged fixty barrels in one fpring. The confequence of this wafte of the juices, was the death of the tree, the enfuing fummer. 1 have this account from the Hon. Paul Brigham, Efq; Thefe accounts ferve to thow, what a quantity of fluid, is naturally contained in fome of our trees; and from a fource fo plentiful, a copious evaporation might naturally be expected.

Emission or AIr. - Another curious operation, which pature carries on in vegetables, of the higheft ufe, 
but wholly invifible to us, is the emiffion of a large quantity of air. The trees, vegetables, and flowers, while they are difcharging a large quantity of water into the atmofphere, and, at the fame time emitting or throwing off a much larger quantity of air. On. the $15^{\text {th }}$ of June, 1789 , I put the fame part of the maple tree into a bottle, as I had done in the experiment of June 12 th. The bottle, with the limb of the maple thus enclofed, was then filled up with water; and immerfed in a large drinking glafs, which had been filled before: In this fituation the bottle was inverted, and fixed fo as to have its mouth about three inches under the furface of the water, in the drinking glafs. - In fifteen minutes, air bubbles began to appear around the leaves of the maple; and foon after to afcend to the upper part of the bottle, and colleet into larger bubbles; which, as they increafed, refolved themfelves into one. At the end of fix hours, I found the quantity of water which had been forced out of the bottle, by the air which was collected in it, amounted to fixty one grains. The quantity of air therefore, eftimated by its bulk, which was emitted from the limb of the tree, was to the quantity of water thrown off from the fame limb, as fixty one to fixteen. Making the calculation in the fame manner as before, this will give fourteen thoufand feven hundred and feventy four gallons, as the quantity of air, thrown off in twelve hours, from one acre of land, thus covered. with trces. - The purity and falubrity of this air is as remarkable as the quantity of it. It has been found that an animal will live five times as long in this kind of air, as in commun air of the beft quality. The purily of the atmolphere, is conftantly impair$\epsilon d$ by the refpiration of animals, by combuftion, the putrefaction of bodies, and by various other caufes. in fuch ways, the air over large and populous cities, is fo greatly and conflantly corrupted, that it would 
foon become unwholefome and noxious to the inhabitants, if it was not removed, or purified.' Na-' ture has made abundant provifion for this purpofe, in the immenfe quantities of air, which new coun:tries fupply. The trees and vegetables perpetually produce it, in large quantities, and in the pureft. ftate ; and the winds carry it from one country to. another, where it is moft wanted.

HEAT.-The principle by which thefe operations are carried on, and which feems to have the greateft effect in vegetation, is heat. Different vegetables. require different degrees of heat, or different climates, to give them their greateft degree of incre 1 le, and perfection. All of them ceale to grow, when their roots are in a ftate of congelation. As foon as the warmth of the fpring comes on, the fap begins to afcend in their trunks, and branches: A fermentation takes place in all their juices, and the vegetation becomes more or lefs rapid, as the heat of the feafon advances. In Vermont, about the roth of May, the maple, which is one of the moft numerous and forward trees of the foreft, begins to put forth its leaves. In one or two days after, the whole body of the woods, appear of a beautiful light green ; and are conftantly growing of a darker colour, for ten or fifteen days, when the darkeft thades become fixed. During this period, the juices of the trees appear to be in a ftate of high fermentation, their internal heat increafes, and the effects of their vegetation appear in an infinite variety of buds, leaves, and Howers. To afcertain the degrees of heat, in differ ent trees, at different times of the year, and to mark their effects on the leaves, and fruits, the following experiments were made. With an auger, of one inch diameter, I bored an hole twelve inches long, into the body of the tree : In this hole, I encloled a thermometer of Farenheit's fcale, ftopping the orifice with a cork, until the quicksilver had acquired the

$$
\text { degree }
$$


degree of heat, which prevailed in the internal part of the tree. The refult of thefe experiments; is fet. down in the following 'Table.

\begin{tabular}{|c|c|c|c|c|c|}
\hline $\begin{array}{l}\text { Time } \\
2789 .\end{array}$ & \begin{tabular}{|c|} 
Heat \\
in a \\
Maple.
\end{tabular} & $\begin{array}{c}\text { Heat } \\
\text { in a } \\
\text { Birch. }\end{array}$ & $\begin{array}{l}\text { Heat } \\
\text { in a } \\
\text { Pine. }\end{array}$ & $\begin{array}{l}\text { Heat } \\
\text { in } 2 n \\
\text { Afh. }\end{array}$ & $\begin{array}{l}\text { Rcmaiks on the ltate of the } \\
\text { Trees. }\end{array}$ \\
\hline May $\begin{array}{l}26 \\
27 \\
28\end{array}$ & $5^{8}$ & 60 & 60 & 60 & $\begin{array}{l}\text { Leaves of the Maple, } \\
\text { about one fixth of their } \\
\text { natural growth. The } \\
\text { orher trees juft in their } \\
\text { bud, without any leaves. }\end{array}$ \\
\hline $\begin{array}{l}\text { June } 30 \\
\text { July } 30\end{array}$ & $\begin{array}{l}72 \\
70\end{array}$ & $\begin{array}{l}72 \\
67\end{array}$ & $\begin{array}{l}7.3 \frac{1}{2} \\
69\end{array}$ & $\begin{array}{l}76 \\
68 \frac{x}{2}\end{array}$ & $\begin{array}{l}\text { Leaves on each tree, } \\
\text { fully grown. } \\
\text { No appearance of de- } \\
\text { cay in the leaves. }\end{array}$ \\
\hline Sept. 15 & 62 & $5^{6}$ & $61 \frac{3}{2}$ & $59 x$ & $\begin{array}{l}\text { Leaves on the Maple, } \\
\text { Birch, and Afh, begin }\end{array}$ \\
\hline OEtob.16 & 45 & $4^{8 \frac{x}{2}}$ & $4^{6}$ & 47 & $\begin{array}{l}\text { to decay, and turn white. } \\
\text { Leaves of the Maple } \\
\text { turned yellow, and be- } \\
\text { gin to fall. Leaves of } \\
\text { the Birch turned white, } \\
\text { and dead; and about } \\
\text { one half of them fallen. } \\
\text { Leaves of the Alh, all } \\
\text { fallon. Leaves of the } \\
\text { Pine, green through the }\end{array}$ \\
\hline Nov. 16 & $43^{\frac{x}{2}}$ & $43 \frac{x}{2}$ & $43 \frac{1}{2}$ & $43 \frac{r}{2}$ & $\begin{array}{l}\text { Noar, } \\
\text { No leaves on tbo Ma- } \\
\text { ple, Birch, or Afh. The } \\
\text { lexattly the fame with } \\
\text { that of the earth, at the } \\
\text { depth of ten inclies be. } \\
\text { low the furface. }\end{array}$ \\
\hline
\end{tabular}

- From thefe oblervations it fhould feem, that the temperature or heat of trees, is not the fame as that of the earth, or atmofphere ; but is a heat, peculiar to this clafs of bodies. It is probably the fame, in all trees of the fame kind, in fimilar circumftances and fituations. The degree and variations of it, feem to depend on the fermentation of the juices, and the flate of vegetation. It is not improbable 
the heat of the fame kind of trees, may be different, in different latitudes: Whether this is the cafe or not, can be known only by obfervations, made in different countries:-This heat which prevails in trees; feems to be the great principle or agent, by which the two fluids of water and air, are feparated from one another, and emitted from the trees. The quantity, of water evaporated from the trees on one acre, in twelve hours; we have: found to be three thoufand eight bundred and feventy five gallons That of air, fourteen thoufand feven hundred and feventy four gallons. Before the evaporation, both thefe fluids feem to have exifted together in a fixed ftate; raking a common mafs, every where difperfed through the body, limbs, and leaves of the trees. When the heat of the internal parts of the trees, became from fifty eight to fixty degrees of Farenheit's thermometer, the buds iwere formed, the leaves put forth, and the one fluid, feems to have been feparated, or formed into the two fluids, of water and air. It feems probable from this, that both thefe fluids had the lame origin, that heat was the principle, or caufe by which they were feparated and that about fifty eight, is the degree of heat, which is neceffary to begin the separation of the air from the water.

ERFECT.-The effect of this perpetual vegetation, growth, and decay of vegetables, is an extreme richnefs and fertility of foil. Neither deftroyed or removed by the hand of man, the vegetable productions of the uncultivated parts of America, return to the earth by decay and death, and corrupt on the furface from which they grew. It is not only from: the earth, but from the air and water, that trees and plants derive their nourifhment, and increafe : $\mathrm{And}$ where no wafte has been occafioned by man or other animals, it is not impoffible that the vegetablea may return more to the earth, than they have taken 
from it ; and infead of ferving to impoverifh, op: crate to render it more rich and fertile. Thus does the foil, in the uncultivated parts of the country, from age to age derive increafe, richnefs, and fertility, from the life, growth; death, and corruption of her vegetables. - This effect has been fo great in America, that when our lands are firft cleared of the wood, we always find a black, foft, rich foil, of five or.fix inches depth; wholly formed of decayed or rotten leaves, plants, and trees. The extreme richnefs of this factitious foil, produces a luxuriancy, of vegetation, and an abundance of increafe in the firft crops, which excceds any, thing that can afterwards be procured, by all the improvements of agriculture.

Powers of Vegrtable Life. - The power with which nature acts in the productions of vegetable life, in this part of America, may be deduced from fuch circumftances as have been mentioned: From the immenfe extent of our forefts; from the magnitude, number, and variety of our trees, and plants; from their rapid increale, and duration; and from the total want of fandy deferts, and batren places. Thefe and other circumftances, denote an energy, a power in the vegetable life, which nature has never exceeded in the fame climate, in any oth. er part of the globe. 


\section{II A P. V.}

Native Animals. - An Account of the 2uadritpeds; with Obfervations on their Enumeration, Origin, Migration, Species, Magnitude, Difpofition, and multiplying Power. The Birds, Fifses, Reptiles, and Insects.

\section{THE uncultivared ftate of America} was favourable to the productions of animal life. A foil naturally rich and fertile, and powers of vegetation extremely vigorous, produced thofe immenfe forefts, which fpread over the continent. In thefe, a great variety and number of animals had their refidence. Fed by the hand and productions of nature, unmolefied but by a few and unarmed men, the productions of animal life every where appeared, in the various forms of quadrupeds, birds, fithes, and infects; and their increale and multiplication, became quick and rapid.

\section{Q U A D R U P D S.}

OF that fpecies of animal, which are known by the name of quadrupeds, America contains nearly one half: Of thefe about thirty $f(x$, are found in Vermont. Our forefts afford thelter and nourifhment for the moofe, bear, wolf, deer, fox, wild cat, acoon, porcupine, woodchuck, dkunk, martin, hare, I. rabbit, 
rabbit, weafel, ermine, fquirrcl, mole, and moufe. In our rivers, ponds, and lakes, the beaver, inukrat, mink, and otter, are to be found in large numbers.

The largeft animal which is known in Vermont, is the Moose. It feems to be of the fame fpecies a the elk; and in its general form, it refembles the horfe. His head is large, the neck fhort; with a thick, thort, and upright mane. The eyes are fmall ; the ears are a foot long, very broad, and thick ; under the throat, there is a fleflyy protuberance; the noftrils are large; the upper lip fquare, and hangs over the lower. His horns are palmated, and when fully grown are about four or five feet from the head to the extremity : There are feveral fhoots or branches to each horn, which generally extend about fix feet in width from each other. The horns weigh from thirty to fifty pounds, and are fhed every year. The hoofs of the moole are cloven; his gait, is a long fhambling trot; his courfe, very fwift, and ftraight. WWher he runs, the ratling of his hoofs, is heard at a confiderable diftance; in miry places, his hoofs are fpread feveral inches flom one another; and it is with the greateft eale, that he leaps over the higheft of our fences. The moofe is generally of a grey, light brown, or moufe colour. The food of this animal is grals, thrubs, the boughs and bark of trees, efpecially the beech, which they feem to prefer above all others, and a fpecies of maple which is called moofe wood. In fummer, they keep pretty much in families. In the winter, they hesd together to the number of twenty or thirty, in a company: They prefer the coldeft places; and when the fnow is deep, they form a kind of yard, confifting of feveral acres, in which they conftantly trample down the fnow, that they may more eafily range round their yard; and when they cannot come at the grafs, they live on the twigs and bask of the trecs. Their defence is chic fly 
chiefly with their fore feet, with which they nrike with great force. The female is lefs than the male, and generally without horns. The rutting feafon is in autumn : The female generally brings forth two at a birth, in the month of April, which follow the dam a whole year. One of thefe animals in Vermont, was found by meafure, to be feven feet high. The largeft, are eftimated by the hunters, to weigh thirteen or fourteen hundred pounds.

The BEAR is frequently to be met with in this part of America, and is always of a black colour. It is nut an animal of the molt fierce, and carnivorous difpofition. There have been inflances, in which children have been devoured by the bear; but it is only when it is much irritated, or fuffering with hunger, that it makes any attack upon the human race. At other times, it will deftroy fwine and young cattle, but has not been known to make any attack upon men; but always aims to avoid their purfuit. The food of this animal is corn, fweet apples, acorns, and nuts. In the end of autumn, the bear is generally very fat, and chnofes for the place of his retreat the hollow of a rotten tree, or fome natural den, or cavern in the earth. In fuch a fituation he ufes no exercife, appears in be afleep, lofes but little by refpiration, and is always found without any provifion; and it is not until the warmth of the fpring returns, that he leaves his retreat, or goes abroad in queft of food. This animal is valuable for its fleh, greale, and ikin. The female generally bears two cubs a year. The bear arrives to a great magnitude in this part of the continent. The largeft, of which the hunters give us any certain information, weighed four hundred and fifty fix pounds.

One of the molt common and noxious of all our animals, is the WoLr. In the form of his body's the wolf much refembles the dog. Ite has a long head, a pointed nole, fharp and erect ears, a fhort 
and thick neck, with tharp and ftrong teeth. IHis eyes generally appear fparkling; and there is a mild-. nefs, and a fiercenefs, in his looks. The colour of the wolf in Vermont, is a dirty grey; with fome tinges of yellow about his ears, and legs.- This animal is extremely fierce, fanguinary, and carnivorous. When a number of them affociate, it is not for peace, but for war and deftruction. The animal, at which they molt of al! aim, is the theep. When they can find a flock of thefe, they feem to delight in flaughtér; tearing their flefh, and fucking their blood, after they are fully fatisfied with the fat of their tender parts. They attack the deer, foxes, rabbits, and are enemies to all other animals; and their attacks are generaily attended with the molt horrid howlings. - They generally flee before the face of the hunter ; but when they have once tafted of human fleth, they become more fierce, and daring, and feem to be inflamed with greater fury. In fuch a fate, there have been inftances in Vermont, in which the wolves have ventured to make their attacks upon men; but they generally retire upor their approach. They are not often to be feen in the day, but in the night venture into our yards, and barns. - Thefe animals are yet in great numbers, in this ftate; they deftroy many of our theep, in the night; and find a fafe retreat in our woods, and mountains; but are gradually decreafing, as our fettlements increafe, and extend.-The wolf is a very prolitic anirnal. The female is in feafon in the winter, but the male and the female never pair. The time of geftation, is about three months and an half; and the young whelps are found from the beginning of May, until the month of July. The hunters have fometimes found in their dens, a male, a female, and a litter of nine young whelps. One of the largent wolves in Vermont, weighed ninety two pounds. There is nothing valuable in thefe animals 
but their fkins, which afford a warm and a durable fur.

The DEER is one of our moft common and val. uabie animals. In the fpring he theds his hair, and appears of a light red; this colour gradually grows darker until autumn, when it becomes a pale, or cinereous brown; and remains thus through the winter. His horns are flender, round, projecting forwards, and bent into a curve; with branches or fhoots on the interiour fide. Thefe branches do not commence, until the deer is three years old; from which period, a new one riles every year ; and by this circumftance, the hunters compute their age. Thefe horns are caft every fpring; the new ones, in the courfe of a year, will grow two feet in length, and weigh from two to four pounds. - The amorous feafon with thefe animals, is in the month of September. From September to March, the bucks and does herd together; early in the fpring they feparate, and the does fecrete themfelves in order to bring forth their young: which generally happens in the month of April. The female generally bears two, and fometimes three, at a birth. The fawns are red, moft beautifully fpotted with white. They are eafily tamed, and become as gentle and domeftic as a calf. The deer is an animal of great mildnefs, and activity. They are always in motion; and leap over our higheft fences, with the greateft eafe. The largelt of which I have a particular account, weighed three hundred and eight pounds. The deer are numerous in Vermont; and on account of their flefh and fkin, are of much value. The reindeer is not to be found in this part of the continent.-But there feems to be another fpecies of the American deer, diftinguilhed chiefly by its horns, and often by its colour. The horns of this deer are never extenfive, broad, and branched, like thole of the common deer : Bist they are round, thick, but little curved, and not 
more than ten or twelve inches in length. This fpecies is generally larger than the other: Several of them have large white fpots, and fome have been killed which were wholly white.

The Fox abounds much in this part of America. The form, difpofition, and habits of this animal, are every where known. Wc have four kinds of foxes in Vermont.

The Red Fox bears upon a yellowifh, or rather a Atraw colour. 'This is efteemed the common fox, and is the molt frequently to be found. At its full growth in the fall, this animal'weighs twenty pounds.

The Grey Fox refembles the other in form, and snagnitude, and appears to differ from it only in colour, which is of a beautiful filver grey.

The Cross Fox relembles the other in form, and magnitude; but has a black ftreak, paffing tranfverfe. ly from houlder to floulder; with another along the back, to the tail. The other parts of this animal are of a red, or more generally of a grey colour.

The Black Fox is the largeft, and mont valuable of all. The fur of this fox is the molt fine, fofe, and sich, of any. One of the largeft of the black foxes, was found to weigh twenty three pounds.

The fox is a very voracious animal; devouring all kinds of poultry, birds, and animals, which they can overcome. Flefh, fruit, honey, and every part of the farmer's áairy are devoured by him with great avidity.-This animal is very prolific. The female is in feafon every year, in the winter; and generally produces in the month of April; the litter is generally from three to fix.

The Catamount, ferms to be the fame animal, which the ancients called Liznx, and which is known in Siberia, by the name of Ounce. In the form of its body, it much refembles the common cat, but is of a much larger fize. It is generally of a yellow grey 
grey colour, bordering upon a red or fandy; and is larger than our largeft dogs.--This feems to be the moft fierce and ravenous of any animal, which we have in Vermont. Some years ago, one of thefe animals was killed at Bennington... It took a large calf out of a pen, where the fence was four feet high, and carried it off upon its back. With this load, it afcended a ledge of rocks, where one of the leaps, was fifteen feet in height. - Two hunters found the cat upon an high tree. Difcharging his mufket, one of them wounded it in the leg. It defcended with the greateft agility, and fury; did not attack the men, but feized their dog by one of his ribs, broke it off in the middle, and inftantly leaped up the tree again with aftonifhing fwiftnefs, and dexterity. The other hunter fhot him through the head, but his fury did not ceafe, but with the laft remains of life.Thefe animals have been often feen in Vermont; but they never were very numerous, or eafily to be taken. Of their fecundity, I have no particular information. On account of their fiercenefs, activity, and carnivorous difpofition, the hunters efteem them the moft dangerous of any of our animals. The weight of one of them, was eftimated by the hunter, at one hundred pounds. The length of his body was about fix feet, that of the tail, three; the circumference of the body was two feet and an half, and the legs were about thirteen inches long.

What is called the WILD $C_{A T}$, is an animal, in moft refpects fimilar to our common cats ; but different in its difpofition, and dimenfions. It is much larger, ftronger, and fiercer, than any of our domeftic cats; and feems to he of the fame difpofition, and colour, as the wolf. One of the largeft of them was found by the hunter, to weigh ffty feven pounds.

The Brack CAT does not appear to be dininguifhed from the former, in any ustor refpect than 
its colour. It is altogether black, and feldom grows to fo large a fize, as the former. It feems to be of a diftinct fpecies; is as fierce and ravenous as the other kind. - Thefe animals are frequently found in the woods ; very wild, extremely fierce in combat, of great activity and ftrength; but never can be tamed, or made to affociate with our common cats. They are valuable only on account of their furs. The black cat was called by the Indians, the Wool. Janeeg: The largeft of which I have any account, weighed twenty three pounds:

Another animal which does not greatly differ in appearance from a wild cat, has been called the Wolverine. The body of this animal is about two feet and an half in length. It has a fhort tail, and is of the fame colour as the wolf.-This animal is of a very fierce, and carnivorous difpofition. Concealing himfelf among the rocks and buthes, or taking a ftation upon the limb of a tree, he watches for the approach of prey. If the deer, or the moofe comes within his reach, he darts upon their backs, faftens upon their neck, and with great dexterity opens their jugular vein with his tecth.-This animal is fcarce, and not to be found but in the northern, and moft uncultivated parts of the fate. I have no account of its fecundity, magnitude, or other particulars.

The RACOON, in its fhape or general form, refembles the fox, but has a larger hody, with thicker and Thorter legs. The feet have five long and llender toes, armed with fharp claws. The males have generally a large whitifh ftripe, and the females a fmaller one, which runs acrofs the forehead. The tail is long, and round, with annular ftripes in it. This animal dwells in the retired part of the woods, runs up the trees with great agility, and vertures to the extremes of the boughs. Its fur is thick, long, and foft; and of a dark grey colour. The weight af one of the largeft in Vermont, was thirty two pounds. 


\section{HISTORY OF VERMONT.}

pounds. It is often found in hollow trees, and its fleth is excellent food.

The PORCUPINE, or Hedgehog, is not uncommon in Vermont. What is fingular and moft diftinguifhing in this animal, are the quills with which he is armed. Thefe quills are about four inches in length; and of the fize of the quills of a pigeon. When the porcupine is attacked by an enemy, he places his head between his fore feet, and crects thefe quills all around, in the form of an hemifphere. He has no power to eject them from his body, or dart them againft hisenemy, as has been frequently faid. But they are fo loofely inferted in his flefh, and of fuch a particular conftruction, that thev are eafily extracted, and iike a barbed dart fick faft, and work themfelves into the flefh of any antmal that touches their extremities; nor can they be eafily withdrawn, without tearing the fleth, but by incifion. On this account they p:ove extremely dangerous to the dog, or to any other animal that makes an attack upon the porcupine. - The colour of this animal, is grey: His motion is extremely flow. Tle female produces her young e:ery year; the time of geftation is about forty days, and the generally brings forth three or four at a birth. One of the largeft of thefe animals, weighed fixteen pounds: The fleth is faid to be agreeable, and wholefome meat.

Another animal, which we frequently find in the folds, is the WoODCHuck. This animal is about lixteen inches in length; its body is large, and round; its legs are fhort; and its fore feet are broad, and fitted for the purpole of burrowing into the earth.The colour of the woodchuck is brown, his fat is extreme, the flefh is wholefome and palatable food, his fur is not very valuable. This animal refides in a hole which he digs in the ground, and feeds upon grafs, corn, beans, and other vegetables. The fe. male generally produces four or five at a birth. One $\mathrm{M}$ of 
of the fatteft which I have feen, weighed eleven pounds: I believe this was one of the large? fize.

The $S_{K U N K}$ is one of the moft extraordinary animals, of which we have any account. It feems to be of the fame fpecies with the polecat, but is of a lefs fize, and differs from it in feveral refpects. - Its hair is long, and fhining, of a clouded or dirty white, intermixed with lpots of black. Its tail is long, and buthy, like that of the fox. It lives chiefly in the woods, and hedges, hut often burrows under barns and out houfes. When undiflurbed, this animal is without any ill fcent, or difagreeable effluvia. Their natural evacuations are not more naufeous, than thofe of other animals. Whole nefts of them will lie under the floor of a barn, and fo long as they are undifurbed, no difagreeable odour will be perceived during the whole winter. Their flefh, when it is properly dreffed, is fweet and nourifhing.- IWhen purfued or attacked, the kunk difcovers its extraordinary powers, by a fingular and moft effectual method of defence. It emits a fluid of the moft naufeous and intollerable fccnt, that has ever been known. So odious, fubtle, and penetrating, is this ill fcented matter, that there is no animal which can long endure it, or will venture to approach the fkunk, when he is throwing it out. It infects the air to the diftance of half a mile all around : And no method has been found, to extraet the fcent out of any object, on which the odious fluid has been thrown. Time and air, after a long period, affords the only complete remedy. By accurate diffection lately made by Dr. Mitcbell, it has been found that this ill fcented fluid, is entirely diftinet from the urine. It is, contained in two bags, fituated in the pofterior parts of the body; and furrounded by the circular mufcles in fuch a manner, that by their conftriction, the tuid is forced out with great velocity and force. The

uriviary 
urinary organs are totally diftinct from thefe bags.* The female produces a litter every year; and they generally amount to five-or fix in number. One of thefe animals wcighed feven pounds and an half, but whether it was one of the largent fize, I cannot determine.

The MARTIN is an animal, peculiar to cold climates. It is found in large numbers in Vermont, but chiefly in the moft retired, and thickeft parts of the woods. Its colour is a dark brown, with tinges. of yellow; fometimes the colour approaches to a black: The fur is fine, foft, and much efteemed.This animal is from eighteen to twenty inches in length. A large one was found to wergh five pounds and one quarter of a pound. The female produces from three to fix young ones, at a litter. The martin and fable denote the fame animal in Vermont.

The HARE is about eignteen inches in length : It is always of a white colour, and has a fine, and beautiful fur: Its flefh is a very nourifhing, and delicious food. This animal is very prolific. The time of geftation is about thirty days: The female bears three or four at a birth, and has feveral litters in the courfe of a year. A large hare weighs eight pounds. The hunters find large numbers of thefe animals, in this part of the country.

The RABв I in greater numbers. His colour, both in lummer and winter, is a light grey, or a dirty white. The length of the rabbit, is about fixteen or feventeen inches; one of the largeft of them, weighed feven pounds. The rabbit is more prolific than the hare. The female bears fooner, and has from four to eight, at a litter. Thefe animals are readily found, in every part of the fate.

The WEASEL has the form and appearance, of a fquirrel; but is more $\mathrm{flim}$, and active. His eyes have

*. American Mufeum, Vol. V.p. $4^{8} 7$. 
have an uncomınon fprightlinefs; his look is keen, and piercing; and his motions are fo quick, and various, that the eye can fcarcely follow them. This animal is of a red or brown colour, and has a white belly. Its fur is very fine, and foft. His food is corn, nuts, eggs, and all kinds of fmall animals. The weaffl is often found in hollow trees, and he frequently enters into houfes, barns, and oiher buildings, in fearch of grán, chickens, mice, and young animis. In Vermont, the weafel is about twelve inches in length; very narrow and flim, and weighs about twelve ounces. The female bears three, four, or five, at a birth; but they do not appear to be very numerous.

The ERMINE is the moft beautiful quadruped, which is feen in our woods. In its form, dimenfrons, adivity, and fecundity, it refembles the wea$\mathrm{fel}$, but is rather larger; one of them weighed fourteen ounces. Its colour is a beautiful white : The tail is tipped with a beautiful black. Some of thefe animals have a fripe of dark brown, or moufe col: our, extending along the back, froin the head to the tail; the other parts being perfectly white. This little, brifk, light, and beautiful animal, has the moft fine and delicate fur, that can be imagined; and the animal itfelf is one of the greatelt beauties of nature.

Of the SeujrRzi we have four or five fpecies; grey, black, red, niiped, and flying.

The Grey Squirrel is the largeft, and moft common. This fquirrel is about thirteen or fourteen inches in length, with a large buftay tail, as long as the body. It is of a beautiful filver grey colour, and has a fine foft fur. Its nelt is in the crotch, or hollow of a tree; its food, corn, acorns, and nuts.' It lays up a -llore of thefe proviforis again th winier, in the hollow of old trees. The female bears her young in the fpring, and has generally three or four at a birth. The 
The largeft of thefe grey fquirrels, when they are fully fatted in the fall, weigh three pounds and an half.

The Black Squirrel refembles the former in every refpect, but its colour, and fize. It is wholly black, without any change in its colour, at any time of the year. Its fize is fomething lefs than that of the grey fquirrel: The largeft I have known, weighed but two pounds and an half.

The Red Squirrel does not appear to differ from the black, in iny other particular, but the colour.

The Striped squirrel is fmaller than either of the other. Tine largell of thefe does not weigh more than nine or ten ounces. This fquirrel digs a hole in the ground, for the place of his refidence. He provides a ftore of nuts, acorns, and corn, againft. winter. Thele are carefully depofited in his neit; and he refides in the earth, during the feverity of the feafon.

The Flying Squirrel is the moft curious, and beautiful of all; and of the fame fize as the ftriped one: This fquirrel has a kind of wings, by which he will pars from one tree to another, at the diftance of thirty or forty feet. None of our animals have a more tine or delicate fur, than this little fquirrel. He feeds on the buds, and feeds of vegetables; and generally has his neft in decayed, and rotten trees.

The Mole, Shreiv Mouee, Ground Mouse, and FIELD MOUSE, are to be found in this part of America: They are fo finall, and well known, that they do not require a particular defcription. The hunters inform me, that there are feveral kinds of mice to be found in the woods, which have not been defcribed: But neither the grey rat, the black rat, or the water rat, is to be found in any part of the ftate.

The quadrupeds which have been defcribed, are to be found only upon the land. Thers are others of 
of an ampbibious nature, which live upon the land, or in the water; thefe are to be found in the rivers, ponds, and lakes.

One of the moft fagacious and ufeful of thefe, is the Beaver. On account of his natural conftitution and inftincts, his focial nature, the works he performs, and the ules to which he is applied, the beaver is the molt extraordinary of all our animals, and deferves a more particular defcription.

The American beaver is between three and four feet in length, and weighs from forty to fixty pounds. His head is like that of a rat, inclined to the earth ; his back rifes in an arch between his head and tail. His teeth are long, broad, ftrong, and fharp. Four of the $\mathrm{e}$, two in the upper, and two in the under jaw, are called incifors. Thele teeth project one or. two inches beyond the jaw, and are tharp, and curved, like a carpenter's gouge. In his fore teet the. toes are feparate, as if defigned to anfwer the purpofes of fingers and hands: His hind feet are accommodated with webs, fuited to the purpole of fwimming. His tail is a foot long, an inch thick, and five or fix inches broad: It is covered with fcales, and with a fkin fimilar to that of fifh.

In no animal does the focial inflinet and babit ap. pear more ftrong, or univerfal, than in the beaver. Wherefoever a number of thefe animals are found, they immediately affociate, and combine in fociety, to purfue their common bufinels, and welfare. Every thing is done, by the united counfels, and labours, of the whole community. Their focieties are generally collected together, in the months of June and July; and their numbers when thus collected, frequently amount to two or three hundred; all of which, immediately engage in a joint effort, to promote the common bufinefs and fafety of the whole fociety; apparently acting under a common inclination, and diredion. When the beaver is found 
in a folitary ftate, he appears to be a timid, inactive, and ftupid animal. Inftead of attempting any important enterprize, he contents himfelf with digging a hole in the earth for lafety and concealment. His genius leems to be depreffed, his fpirits broken, and every thing enterprizing is loft in an attention to perfonal lafety; but he never loofes his natural inftinct to find or form a pond.* When combined in fociety, his difpofition, and powers affume their natural direction, and are exerted to the tigheft advantage : Every thing is then undertaken, which the beaver is capable of performing.

The fociety of beavers feems to be regulated and governed, altogether by natural difpofitions, and laws. Their fociety, in all its purfuits and operations, appears to be a fociety of peace and mutual affection; guided by one principle, and under the fame direction. No contention, difagreement, contrary interefts, or purfuits, are ever feen among them; but perfeet harmony and agreement, prevails through their whole dominions. The principle of this union and regulation, is not the fuperiour ftrength, art, or activity of any individual : Nothing has the appearance, among them, of the authority, or influence of a chief, or leader. Their allociation, and management, has the afpect of a pure and perfect democracy ; founded on the principle of perfect equality, and the frongef mutual attachment. This principle feems to be fufficient to preferve the moft perfect harmony, and to regulate all the proceedings of their largeft focieties.

When thefe animals are collected together, their firt attention is to the public bufiness and affairs of the fociety, to which they belong. The beavers are amphibions

* A young beaver was tamed in the fouthern part of this ftate. He became quiet, inoffenfive, and without any difpos. fition to depart. But was moft of all pleafed, when he was a: work, forming a dam, in a fmall ftreani near tbe houfe. 
amplabious animals, and muft fpend one part of their time in the water, and another upon the land. In conformity to this law of their natures, their fin $\mathrm{ft}$ cmployment is to find a fituation, cunvenient for both thele purpoles. With this view a lake, a pond, or a running ftream of water, is chofen for the fcene of their habitation, and future operations. If it be a lake, or a pund that is felccted, the water is aiways of luch depth, that the beavers may have lufficient room to fwim under the ice ; and one, of which they can have an entire, and undifurbed poffeffon. If a ftream of water is chofen, it is always fuch a ftream, as will form a pond, that thill be every way convenient for their purpole. And fuch is their forefight and comprebenfion of the fe circumnances, that they never form an erronenus judgment, or fix upon a fituation that will not an/wer their defigns and ronvenience.-Their, next bufinels, is to conftruct. a dam. This is always chofen, in the mott convenient part of the ftream; and the form of it, is either direct, circular, or with angles, as the fituation and circumftances of the water and land, require: And fo wcll cholen is both the place, and the form of thefe dams, that no engineer cculd give them a better fituation and form, either for convenience, ftrength, or duration. - The malerials of which the dams are conflucted, are wood, and eaith. If there be a tree on the fide of the river, which would naturally fall acrofs the ftream, feveral of the heavers fet themfelves with great diligence, $t \theta$ cut it down with their teeth. Trees to the bignefs of twenty inches diameter, are thus thrown acrofs a fream. They next, gnaw off the branches from the trunk, that the tree may allume a level pofition. Others, at the fame time, are cutting down fmaller trees, and faplings, from one to ten inches diameter. Thefe are cut into cqual and convenient lengths. Some of the beavers drag thefe pieces of wood to 
the fide of the river; and others fwim with them to the place, where the dam is to be built. As many as igan find room, are erigaged in:finking one end of thefe ftakes ; and as many inore in raifing, fixing, and fecuring the other end. While many of the beavers are thus labouring upon the wood, others are equally engaged in carrying on the earthen part of the work. The earth is brought in their mouths, formed into a kind of mortar with their feet and tails, and pread over the; Nacancies between the ftakes, Saplings; and the fmall branches of trees, are twifed and worked up with the mud and flime, until all, the vacancies are filled up; and no crevise is left in any part of the work, for the water to find a palfage through - The magnitude and extent of the dams, which the beavers thus conftruet, is much Jarger than we thould imagine was poffible to be effected, by fuch labourers, or inftruments it the bottom, the dam is from fix to twelve feet thick ; at the top, it is generally two or three feet.in width. In that part of the dam, which is oppofed to the current, the fakes are placed obliquely ; but on that fide where the water is to fall, the ftakes are placed in a perpendicular direction; and the dam affumes the fame, form, and polition, ' as the ftakes. The extentof thefe works, is from fifty to an hundred feet in length; and always of : fuch an height, as to effect the purpofes they have in view. : The ponds which are formed by thefe dams, are of all dimernfrons from four or five, to five. or fix hundred acres. They, are generally fpread over lands abounding with trees, and bufhes, of the fofteft wood: Maple, birch, alder, poplar, : willow, \&c. - The better to preferve their dams, the beavers always leave giaices, or palfages near the middle, for the redurdant, waters to pars, off. -Thefe fluices are generally about ejghteen inches in width, and depth; and as

many 
many in number, ads the waters of the Arean generally require.:

When, the ipultic rvosks are completed, their domefic concernsisnd affeirs next engage their alteirtion. The dam is no fooner completed, than the beavers feparate into fmall bodies, to build cabins, or houfes for themfelves. Thefe lioufés are 'built upon piles, along the borders of the pond. They are of an oval form, "refembling the conftrution of an haycock; and they wary in their dimen lions, from four to ten feet in dianteter; according to the number of families they are defigtred to accómodate. They are always of twa ftories; generally of three, and fometimes they contain four. Theif walls are from two to three feet in thicknefs, at the botton' and are formed of the fame materials as their daris. -They rile perpendicularly a few féet, their alfume a curved form, and terminate in a dorre or vautt, which anfwers the purpofe of a roof.' Thefe edifices are built with much folidity, and neatrels. On the inward fide, they are fmooth, but rough on the outfide; always impenetrable to the rain, and of fufficient ftrength to refitt the molt impetuous winds. The lower ftory is about two feet high: The fecond ftory has a floor of fticks, covcred with mud: The third flory is divided from the fecond, in the fame manner, and terminated by the roof raifed in the form of an arch. Through each floor, there is a communication; and the upper floor is always abovie the level of the water, when it is railed to its greateft height. Each of thefe huts have two doors; one, on the land fide, to enable them to go out and procure provifions by land; another under the water, and below where it freezes, to prefervestheir comnunication with the pond. If this, at any time begins' to be covered with ice, the ice is immediately. broken? that the communication may not be cut off with the air. 
In thefe huts, the families of the beavers have their refidence. The rmalleft of their cabins, contain one family, confinting generally of five or fix beav crs; and the largent of the buildings, will contain from twenty to thirty: No fociety of animals, can ever appear better, regulated, or more happy, than the family of beavers. The male and the temale, always pair. Their felection is not a matter of chance, or accident ; but appears to be derived from tafte, and mutual affection. In September, the happy couple lay up their ftore of provifions, for winter. This confints of bark, the tencier twigs of trees, and various kinds of foft wood. When their provifions are prepared, the feafon of love and repore commences: And during the winter they remain in their cabins, enjoying the fruits of their labours, and partaking in the fweets of domeftic happinefs. Towards the end of winter, the females bring forth their young, to the number of three or four. Soon after, the male retires to gather filh, and vegetables, as the fpring opens; but the mother remains at horne, to nurfe, and rear up the offspring, until they are able to follow their dams. The male occafionally returns, but not to tarry, until the fall of the year. But if any injury is done to their public works, the whole fociety are foon collected, and join all their forces to repair the injury, which affects their commonwealth.

Nothing can exceed the peace and regularity, which prevails in the families, and through the whole commonyealth of thele animals. No difcord or contention ever appears in any of their families. Every beaver knows his own apartment, and ftore houle; and there is no pilfering or robbing from one another. "The male and the femalc are mutually attached to, never prove unfriendly, or defert ons apother. Their provifions are collteted, and expended, without any diffention. Fach kuows its onn fami) $y$, 
ily, bufriefs, and property ; and they are never feen to injure, oppofe, or interfere with one another. The fame order and "tranquillity" prevail, through the commonwealth. Different focieties of beavers;" never make war upon "une another, or upón any other animals. When they are attacked by their enemies, they inftantly plunge into the water, to efcape their purfuit : And when they cannot efcape they fall an eafy facrifice.

In the arts neceffary for their fafety, the beavers' rife to great eminence. The fituation, direction, form, folidity, beauty, and durability of their darns, are equal to any thing of the kind, which has ever been performed by man." They always form a right judgment, which way the tree will fall: And when it is nearly cut down, they appoint one of their number, to give notice by a ftroke of his tail; when it begins to fall. With their tails, they meafure the lengths of their dams, of the flakes they are to ufe, of a breach that is made in their works, and of the Iength of the timberr that is neceffary to repair it. When an enemy approaches their dominions, the beaver which makes the difcovery, by friking on the water with his tail, gives notice to the whole village of the approaching danger; and all of them inftantly plunge into the water." And when the hunters are paffing through their country, fome of their number appear to be centinels, to give notice of their approach.

The colour of the beaver is different, according to the different climates, which they inhabit. In the molt northern parts, they are generally black; in Vermont they are brown, and their colour becomes. lighter as we approach towards the fouth.-Their fur is of two forts, all over their bodies. That which is longeft, is generally about an inch long, but on the back, it fometimes extends to two inches, gradually fhortening towards the hend, and tail. . This 
part is coarfe, and of little ufe. The other part of the fur, confifts of a very fine, and thick down; of about three quarters of 'an inch long, fo foft that it feels like filk, and is that, which is ufed in manufactories.-Caftor, of fo much ufe in medicine, is produced from the body of the beaver. It is contained. in four bags, in the lower belly.

The largett of thefe animals, of which I have any certain information, weighed fixty three pounds and an half: But it is only in a fituation remote from; and undifturbed by the frequent appearances of men, that they attain their greateft magnitude, or their higheft perfection of fociety. The beaver has déferted all the fouthern parts of Vermont, and is now to be found only in the molt northern, and uncuiltivated parts of the ftate.

The MUSKRAT feems to be a fmaller kind of beaver, refembling it in every thing but its tail. This is alfo an amphibious animal, and forms a cabin of fticks and mud, in forrie flagnant water; but is lefs fearful of the approaches of men, and affords a very ftrong mitk. Thefe animals are to be found, in very confiderable numbers, in our creeks, and lakes; but are much lefs numerous, than they were formerly. The mufkrat, in this part of America, is about fifteen inches in length; the greateft magnitude I have known is five pounds and three quarters of a pound. A litter of thefe mulkrats, will frequently amount to four, five, and fometimes fix.

Another of our amphibious animals; is the MrNk. It always refides in the neighbourhood of rivers, ponds, or lakes ; and provides a place of refidence, by burrowing into the ear h. - The mink is about twenty inches in length; his legs are thort, his colour brown, and his fur is more valuable than that of the mufkrat. Orie of the largeft which I have known, weighed four pounds and one quarter of a pound. The female produces two or three, at a birth. 
The QTtER is a voracious nnimal, of great, a otivity and fiercenels, When it is fully grown, it is five or fix feet long; with tharp and frong tecth: thort legs, and membranes in all his fect; and fitted cither for running, or fwirnming.-The otter explores the rivers and ponds in fearch of filh, frogs, water rats, and other fmall animals: And when thefe are not to be had, he lives on the boughs and bark of young, or aquative trees. He has generally been. ranked among the amphibious animals, which can live either in the air, or water; but he is not properly an amphibious animal, for he cannotlive without relpiration, any moie than the land animals. "The female is in heat in the winter, and bears her young in the month of March; the litter generally confifts of three or four. "The fiercene?s and ftrength of the old otters, is fuch, that the dog can feldom overcome them: And when they cannot efcape, they will attack the hunter with great rage. - The colour. of this animal is black, and irfur is much efteemed. The otter formerly abounded very much in our creeks, and rivers; and efpecially in thofe, which emptied themfelves into. Lake Champlain: On this account, one of them fill bears the name of Otterereek; but the animal is now become fcarce. The larget otter, of which I have a particular account, weighed twenty nine pouncis and an half.

To this account of the quadrupeds of Vermont, I thall fubjoin fome reflections on the general fate of thefe aninials, in America.

The enumeration very imperfect.-Our accounts of the quadrupeds in this, and in every part of Ameri. ca, muft be viewed as greatly imperfect. The defcendants of Europe have fettlerl along the fea coafts, and they have penetrated to the lakes, ard molt of the navigable rivers. But the internal parts of South, america, are but little known: And all that immenfe traet of country, which lies to the north, and to the welt 
went of the lakes, is wholly urexplored. It is not to bc doubted, but thefe extenfive regions, abound with quadrupeds : Of what fpecies, and how numerous, we cannot fo much as conjecture. When the country flall be fully cxplored, and when all naturalins Thail have vifited and examined the internal parts, the hittory of the animals of America, may be brought to fome peifection; but it is far from it, at prefent. Alt the animals which have been enumerated, are only thofe which are frequeritly found, in a fmall part lof the continent. - That an animai of great and uricomnoir magnitude, has exilled in Northamérica, and in Siberia, is certain from the tones of the animal which yet renain. On the banks of the Ohio, and in inany places furtlier noth, tuiks, grinders, and Tkeletons, of an enormous lize, are to be found in great nunibers. Some of them lie upon the furface of the giound, and others are five or fix fect below it. "Some of the tulks are near feven fect long, one foot and nine inches at the bafe, and one foot riear the point the cavity at the bafe, nineteen inches deep. From the fize and thicknefs of thefe bones, it is certain that they could not belong to the elephant; but deriote an animal five or fix times as large, and of the carnivorous kind.-We have the teftinony of the Indians that fuch an animal niti exifts in the weftern parts of America : And it would be contráry to the whole econotny of nature, to fun pole that any fpecies of her aninals, is become ex-

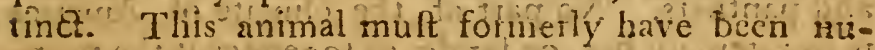
merous, at thole places; where their bones arc found in fuch numbers. The probability is, as the means of fubfiftence were deftroyed; they remored further to the weftward.' But until thole parts of America fhill be explored, little information is to be expec:ed concerning this animal of the moft enormous bulk: And we niay as well call it the Mcmiotb, as by any other ndme ; or the Potdo Elepboit, as if 


\section{THR NATURAL AND CIVIL}

has been named by Dr. Hunter,-From this, and from many other confiderations, it appears that the enumeration of the American quadrupeds, is extremely imperfect.

ORIGIN - The animals which are pread over the face of the earth, are fitted by nature, for the climate and country, where they refide. No animal, ar vegetable, has a conflitution adapted to every country : And there are none, but what are fuited to fome particular part of the earth, where they. will arrive to their greaten perfection. A camel is peculiarly fitted, for the burning Tands of Arabia : And the reindeer will flourifl the beft in Lapland, Hydfon's Bay, and thofe northern countries, where the cold is the moft intenfe. The origin therefore of different quadrupeds, is to be fought in thofe climates, that appear to be the beft adapted to their growth and multiplication. - Theie are animals in the torrid zone in America, which are never tound in any other part of the earth. This is the cafe with the Tapyr of Brafil, the Puma and Jugar, the Lama, and $P$ aco. There animals have never wandered into any other part of the globe: They, are therefore to be efteemed indigenous, or natural to the hot climates of America. The fame is the cafe with the animals of the torrid zone in A fra, and Africa. The elephant, and rhinoceros, are productions of Afra. The deferts of Laaza and Biledulgerid in Africa, may be termed the native country of lions, tygers, and panthers. No part of the climate of America is fo intenfely hot, or fandy, as to render it the proper country for the production or increafe of animals; fo fierce and noxious. Thefe quadrupeds of hot climates, have never wandered from the one country, to the other: Not becaufe they could not find a paffage, but becaufe they munt have paffed through a climate, the cold of which, being fuch as they could not endure, was an effectual bar to their paffage.-

There 
There are other quadrupeds which are common to America, to the north of Afia, and to Europe: "Of this kind are the buffalo, white bear, carabou, black bear,' elk, moole, red deer, fallow deer, wolf, roe, glutton, lynx, wild cat, beaver; badger, red fox, grey fox, black fox; otter, monax, vifon, porcupine, martin, water rat, weafel; ermine; flying fquirrel, mole, and moufe. If we add the unknown animal, which we have called the mammoth, the number of thofe quadrupeds which are common to both hemifpheres, will amount to thirty." All of them; are the quadrupeds of cold countries ; fitted by nature to that clinate, through w aich the 'paffage mult have been, from the one country to the other. "The original fituation therefore of thefe "quadrupeds, muft have been a cold country. But whether they paffed from the northeaftern parts of Afra, into "America; or whether theyiffued from the north'welt parts of A'nerica, into Afia ; we have no way to determine. . The probability is equal, upon either fuppoficion. All that we can determine is, that they were-originally the quadrupeds of a cold climate.

- Míg ATión:-A nimals of every kind when opprefled by hunger, haraffed by their enemies, or when they can find a more comfortable fituation, will migrate from one country to another." Their migration when cholen and voluntary, is always with a view to better accommódations; to a fituation more favourable: for food, growth, and multiplication. Directed by the hand of nature, their natural progrefs is not to a worle, but to a better Gituation." They do not leave their own country, to fettle in one lefs. fuited to their fubfiftence, and increafe ; but to acquire greater advantages; an increafe of food, num. bers, and vigour:- Whether the migration of quad:rupeds then was from Afia, or from America, there can be no doubt, but that they found in the countly. to which they repaired, a climate, foil, and means of

o $\quad 1 . . .$, fubfiltence, 
fubfitence, equally favourable to them, as thofe which they teft. LHad there been any, very great difference in the provifions, and accommodations: $q \mathrm{f}, \mathrm{na}$ ture, in either country, the quadrupeds that, could tafly migrate, would not haye remained for any con-

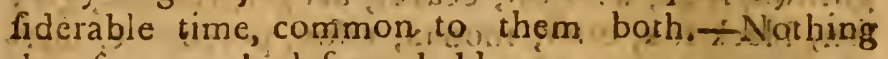
therefore can be lefs probable, or more contrary, to the laws, tendencies, and operations of nature than the European idea firft introduced by $M$. Buffon, that the quadrupeds of Europe migrated into a country in America, where, every thing; was adapted by nature, to their diminution, gegradation, and decreafe. Had not the northern parts of $A$ fia; and America, been well fuited to the fubfiltence, vigeur, and increafe, of thele quadrupeds, there would not have been any voluntary; migration, from the one to: the other; nor would thefe animals have remained; for folong a time, common to them both.

SP'Ec1ES.-How far nature, has proceceded in the? production of quadrupeds, we, have not as yet, fufficient infurmation to determine, There may be many fpecies, yet unknown; in thof parts of the: earth which have not begn explored: Nor is the enumeration complete, in thole countries which are known: The molt that has been done in this branch of natural hiftory $y_{2}$ is to be found in the celebrated work of M. Buffon. As the refult of his inquiries i

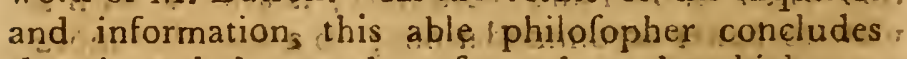
that the whole number of quadrupeds, which are spread over the face of tho earth, will form about two hundred different fpecies or kinds, , Of thefe, t one hundred are found in America, and about fev- : enty five are peculiar to it. If the power, the force, or the vigour of animated nature, is to be eftimated by the fpecies of quadrupeds, which differcent countries contain, the conclufon iy ill be, that nature has acted with the greatef vigoux and energy in Amer-s 1ça. . 51 
ica. In the different obimates in America, nature has produced feventy fifve: fpecies of quadrupeds : The number of thofe which are peculiar to the other parts of the globe are one hundred. ... The dimenfons of America, campared with the dimenfions of Afia, Africa, and Europe; by : the computation of the modern geographers, are as one hundred and farty one to two hundred and forty nine.* The ratio of one hundred andiforty one to two ${ }^{1}$ hundred and forty nine is the fàme as feventy five to one liundred and thirtyitwo. And fo many fpecies fhould be found, in the other parts of the giobe, to preferve an equality $d$ But this is thirty two more, than nature has produced. II refpect then to the different fpecies of quadrupeds, if ve are to judge by any enumeration. Which has yet beén made, ithe greateft force and vigour of nature is found in America.t

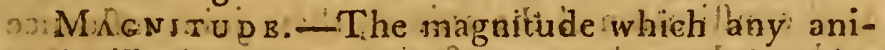
mal will attain, ifeems to depend'nuch upon its original conftitution, the climate, and proper nourifiment.- Im the ioriginal conftitution of each animal, the Creator feems to have eftablifhed certain laws, refpecting its form, 'generation, expanfion, and fupport." The proper'magnitude of the animat, is therefore afligned by nature, to each fpecies, : In this way, the original limits arefixed; above, or below which, no individual of táat foecies fhall rife, or fall. Within thefe limits, thofe vations may take place, which we mean to exprefs, when we call the animal great, or fmall. Bat no circumftance will reverfe the laws of nature, enable the different fpecies of animals to exchange thoir proper form, and magni-

*'Gęthrie's Geogtaphy p..2.5.

1. The enumeration of quadrupeds fems tobo, too inperfect to afford any accurte calculations of this kipd. "Acoording

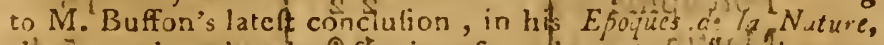
there are three hundred f́pecies of quafrupeds. rit if hiet: coofding to the $\Lambda$ bbe Clavtgero, containg about one hat for thefe.

s.... i 
tude ; to debafe the ox into a mole, or to exalt the mole to the fize of the ox:-Nature has alfo fitted each quadruped for the climate; in which it was oriunally.placed; and in that climate only, will it att in its proper perfection. The lion would lofe its fiercenefs, and perifh, if it was removed to Lapland; and the reindeer would diminith, and die, if it was carried to the fandy: deferts of Africa. In thofe climates only, to which nature has adapted each animal, will it attain its greateft magnitude, and moft perfect form. - The anirnal, to which nature has thus affigned its proper conftitution, and climate, muft be preferved and lupported by proper food, or nourifhment. A deficiency here, will bring on leannefs, impotency, a diminution of fize, and a gradual wafte and confumption of the whole fpecies. But when the climate, and the food, are both fuited to the nat:ural conftitution of the animal, their joint influence will produce the greateft fize or magnitude, that fpecies will admit.

By comparing the magnitudes of fuch quadrupeds in Europe, and in : America, as are common to both, and derive their fupport from the hand of nature, we thall of confequence have another comparative view of the vigour and force, to which animated nature arrives, in each country: Several of thofe quadrupeds, whofe, weight has been afcertained in Vermont, M. Buffon has given us the weight of in Europe : : They are thefe,

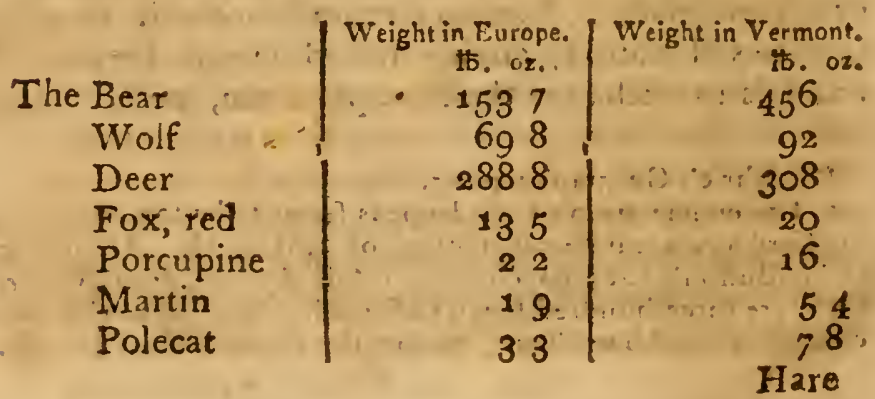




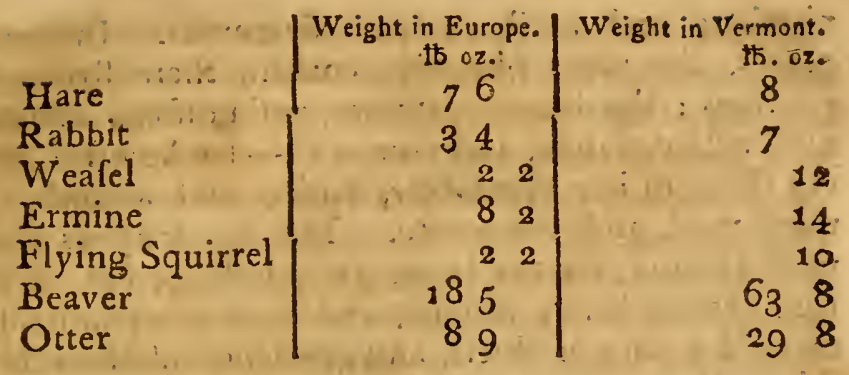

From this comparion it appears, that every one of thefe animals, is larger in America, than it is in Europe. The inference is clear, and decifive : It is in America, and not in Europe, that thefe quadrupeds of a cold climate, attain their greateft magnitude, and higheft perfection.

If the comparilon fhould be made, between the quadrupeds of the torrid zone, the reverfe will be found to be the cale. The elephant, the rhinoceros of Afia, are much larger than the quadrupeds of Peru and Brafil. The truth is, America is the moft favourable to the productions, and growth, of the quadrupeds of cold climates: Afra is the moft $\mathrm{fa}^{-}$ vourable to the productions, and growth of the quadrupeds of a bot climate. But the greateft of all animals; the Mammoth, was not an animal of the torrid, but of the temperate zone ; and was the production of both countries, of Afia, and of America.

TEMPER AN D Disposition:-Molt animals have a particular difpofition and charaçter affigned to them by nature, indelibly fixed, and which difinguithes the whole fpecies. Thus fome are naturally fierce, fanguinary, and carnivorous; while others are mild, temperate," and gentle : And all of them, are not a little influenced, by the climate they inhabit. - In the hotteft climate, and in the burning fands of Africa, the moft ravenous, and the fierceft animals abound : The lion, the tyger, and the panther; are there; in their greateft fize, their largeft numbers, 
numbers, and molt extreme "fiercenels. In fuch places, the vegetables allo contain their ftrongeft qualities; the drugs, perfumes, and poifons, are the molt active, fubtle, and powerful, - In America evéry thing in her vègețables, fruits, and animals, is more mild, and temperate. The quadrupeds that mont abound, are the lama, paco, buffalo, elk, deer, fox, beaver, hares, rabbits, and fquirrels; animals, marked with a mildnefs, and gentlenefs of character. Thole that are the moil fierce, the bear, the wolf, the wildcat, the otter, the congar, or tapyr, are, feldom known to make their attacks upon men, unlefs they are impelled to it by extreme hunger, provoca tion, or felf defence. - It was not therefore with the moft fierce and ravenous animals, that America abounded: Her quadrupeds were of a more mild, and temperate difpofition. To thefe, her clingte gives the greatent Gze, the highent perfection, and the largeft increafe.

INCKEASE AND MULTIPLYING POWER.-The increafe and multiplying power of animals, is derive ed partly from nature, and partly from fituation. and other circumftances. Nature has made thofe animals which are the moft large, fierce, and noxjous, the leaft apt to multiply.. The fmaller and more ufeful any quadruped is, the more rapid is its increafe. All of them bring forth their young, at that feafon of the year, when nature has mader the moft fuitabie and ample provifion, for their food and fupport. And then they do multiply with the greateft rapidity, when they are the leaft molefted by man. - But whatever be their mulciplying power, it would require a lang period of time, before they would arrive at that increafe of numbers, in which their progrefs would be checked, by the want of food. They would naturally fpresd over the whole continent, before they arrived to fuch a ftate. sim This they hạd done in every part $\rho f_{\text {Americh, }}$ wher it 
Was figft difcovered by the Europeans: Every part of the continent, fitted for their nourifhment and growth, abounded with them:- How far nature máy proceed this: way; or what is the greateft number of quadrupeds, that the uncultivated ftate of any country will fupport, we have no obfervations to determine. But it feems probable, that the maximam had already taken place; that America contained her full number of quadrupeds. No obfervations ot phenomena, denote that there has been) any increale of thefe animals, in the ancultivated parts of the continent, fince its firft difcovery, ox that they evét were more thick and numerous, in any ather part of the globe.-How longl a period nature required to advance to this tate in América; we have no data to determine. But if we may judge of the energy with which the acts, from the effects of her multiplyingt power, the conclufion will be, that in no couritry has fhe difplayed greater powers of fecundity than in $A=$ merica. Thefe circumftances denote an high antiguit $y$, in the origin of the American quadrupeds; and a great fertility in that climate and country, in which they have attained their greated numbers, theis: greaten magnitude, and their greatelt fecundity.

$$
B \quad I \quad R \quad D \quad S
$$

.THE birds which abound in every part of A merica, make a cutrous and teautiful pait of her natural hiftory Cabloy has given an elcgant defcriplion of the birds of Carolina. Belkrap has furnithed a good catalogue of thofe of Newhampliire. Moft of the birds which häve been mentioned by thefe authors aucito be found in all the nothern fates As we; approuclifurther towards the norti, a great number and variety of water fowl are to be pound in the lakes, rivers; and harbours, which have inefer besn
defuibed or clatted, w... 
In Vermont we have moft of the birds, which-are known in the inland parts, and lakes of the northern climates. Some of them feem to be fitted by nature, to endure all the feverity of our climate, and are to be feen in the coldeft weather of our winters. Of this kind, are

The Crow. Corvus cornix.

Hawk, forked tail. Falco furcatus.

Owl. Strix afo.

Blue Jay. Corvus crijatus.

Snowbird. Emberiza byemalis.:

Partridge. Perdix folvefris.

Woodpecker, red headed. Picus capite soto nibro.

There are feveral other birds, the robbin; blackbird, lark, fnipe, bluebird, \&c. which are feen as foon as the fnow goes off, in the fpring. They are not feen in the winter, but they are found late in the fall. From their late and early appearance, it is not improbable that fome of them may tarry here through the winter.

Thofe which are efteemed birds of paffage; with the ufual times of their appearance; and departure, are

Time of Ap. Departure.
pearance. The Snowbird. Emberiza byemalis. Nov. 20. April s. Wild Goole. Anas cañadenfis. March 15. Novo.20. Wild Pigeon. Columba migratoria. March 20.1 : oc̣. io. Houfe Swallow. Hirundo cauda acculeata.

Barn Swallow. Hirundo ruftica.

Ground Swallow. Hirundo riparia. Black Martin. Hirundo perpurea.

The SNOWBIRD is a beautiful, active, fprightly, little animal. They are generally of a grey colour, and lefs than a fparrow. Flocks of them appear, as foon as the fnow begins to fall in any confiderable quantity; and generally a day or two before., They perch on the fpires of regetables above the fnow, on 
the bufhes, and trees; and collect on the fpots of bare ground. In the molt fevere ftorms of fnow, thefe birds appear to be the moft active and lively. They feed on the feeds of vegetables, and are extremely fat, and delicious; but they are too fmall to be molefted on this account. They feem to be of different colours, black, white, and grey; but they all difappear as foon as the fnow goes off.

The WILD GoosE, from the beginning of April, to the middle of November, refides chiefly in the more northern, and northeafterly parts of America. In thofe parts they produce their young, and are to be found in the rivers and harbours, in immenfe numbers. In November they come in large flocks from the north, and northeaft, and pals off to the fouthweft. In March and April, they return from the fouthweft in a contrary direction, and go back to their fummer habitation. Thefe flocks frequently confift of fifty or fixty: They fly at a great height, and appear to obferve great regularity in their paffage. They fometimes follow one another in 2 ftraight line, but are more generally drawn up in the form of a wedge; and appear to be led by one of the ftrongeft, and moft active. While they keep together, they feem to underftand their courfe per fectly well; but if by any means their order is broken, and the flock difperfed, feveral of them wander out of their courfe, appear to be perplexed, defcend to the earth, and are often killed or taken. When tamed, they will join with a flock of domentic geefe; but at the ufual times of migration, are very apt to join any flock, which approaches near to them, in their partage.

In the WILD PIGEON, the multiplying power of nature acts with great force and vigour. The male and female always pair: They fit alternately upon the eggs, and generally hatch but two at a time; but this is repeated feveral times in a feafon.-The 
accounts which are given of the number of pigeons in the uncultivated parts of the country, will appear almoft incredible to thofe who have never feen their nelts. The furveyor, Ricbard Hazen, who ran the line which divides Maflachuletts from Vermont, in 1741 , gave this account of the appearances, which he met with to the weltward of Connecticut river. "For three miles together the pigeons' nefts were fo thick, that five hundred might have been told on the beech trees at one time; and could they have been counted on the hemlocks, as well, I doubt not but five thoufand at one turn round.",* The remarks of the firft fettlers of Vermont, fully confirm this account. The following relation was given me, by one of the earlieft lettlers at Clarendon: "The number of pigeons was immenfe. Twenty five nefts were frequently to be found on one beech tree. The earth was covered with thefe trees, and with hemlocks, thus loaded with the nefts of pigeons. For an hundred acres together, the ground was covered with their dung, to the depth of two inches. Their noife in the evening rwas extremely troublefome, and fo great that the traveller could not get any fleep, where their nefls were thick. About an hour after funrife, they rofe in fuch numbers as to darken the air. When the young pigeons were grown to a confiderable bignefs, before they could readily fly, it was common for the fettlers to cut down the trees, and gather a horfe load in a few minutes." The fettlement of the country has fince fet bounds to this luxuriancy of animal life ; diminifhed the number of thefe birds, and drove them further to the northward.

We have four fpecies of Swa l Lows in this part of America. 1. The houfe fwallow. This may be readily diftinguifhed from the reft, by the greater forkednefs

* Belknap's Hiftory of Newhampthire, Vol. III, p. 171. 


\section{HISTORY OF VERMONT.}

forkednefs of its tail. It has alfo a red fpot upon its forehead; and under its chin. This fpecies build their nefts in chimneys. Their nefts are made of fmall fticks, cemented together, with a kind of gum, and mud; they are covered or arched over the tops, and the aperture is on one fide. Thefe fwallows appear the earlieft of any, in the fpring: And a few days before their departure in the fall, they affociate on the tops of buildings, dry trees, and bufhes, as if about to depart in companies. 2. The barn fwallow. The fize of this, is rather lefs than that of the other; and the tail is not forked fo much. This fwallow builds his neft in barns and out houfes; and they are formed of grafs, ftraw, and feathers. Their eggs are fpeckled, of a dark brown and white. It is called the barn fwallow from the place in which it generally builds its neft. 3. The ground fwallow. This is the fmalleft of the whole fpecies. There fwallows form a hole in fandy banks, and on the fides of rivers, of eighteen or twenty four inches in length. Their nefts are made at the extremity of thefe holes, of ftraw and feathers, laid together in a loofe and carelefs manner. Their eggs are perfectly white. The holes in which they are laid, are defigned only for their nefts : None of the fwallows ever remain in them, during the winter. 4. The black martin. This is the largeft of all our fwallows. They build their nefts under the eaves of houles, in the fecret or retired places of out houles, and old buildings. Their nefts are made of ftraw and feathers. They arrive the lateft, and difappear the fooneft of any of the fwallows, which vifit us.

The ufual times of the appearance and difappearance of thefe birds, ferve to mark the temperature of the climate, with as much precifion, as any of the phenomena of nature. But they do not feem to be properly birds of paffage. At Danby in this ftate, the inhabitants report, that fome of them were taken 
out of a pond in that town, fome years ago. A man was employed in the winter, to procure the roots of the pond lily, for medicinal purpoles. Among the mud and roots which he threw out, feveral fwallows were found inclofed in the mud; alive, but in a torpid ftate. The account is not doubted among the inhabitants; but I have not the teftimony of any perfons who faw thefe fwallows. - It has been doubted by fome able naturalifts, whether it is poffible for the fwallow to live in fuch a fituation. I faw an inftance, which puts the poffibility of the fact bey ond all room for doubt. About the year 1760 , two men were digging in the falt marfh at Cambridge, in Maffachufetts: On the bank of Charle's river, about two feet below the furface of the ground, they dug up a fwallow, wholly furrounded and covered with mud. The fwallow was in a torpid ftate, but being held in their hands, it revived in about half an hour. The place where this fwallow was dug up, was every day covered with the falt water; which at every high tide, was four or five feet deep. The time when this frallow was found, was the latter part of the month of February; but the men affured me, they had never found any other fwallows in fuch a fituation. The fpecies called the houfe or chimney fwallow, has been found during the winter, in hollow trees. At Middleb:sy in this ftate, there was a large hollow elm, called by the people in the vicinity the fwallow tree. From a man who, for feveral years, lived within twenty rods of it, I procured this information : Ile always thought the fwallows tarried in the tree through the winter, and avoided cutting it down, on that account. About the firft of May, the fwallows came out of it, in large numbers, about the middle of the day; and foon returned. As the weather grew warmer, they came out in the morning with a loud noife, or roar, and were foon difperfed: About half an hour before fun down, they returned in mill. jons, 
ions, circulating two or three times round the tree, and then defcending like a ftream, into a hole about fixty feet from the ground. It was cuftomary for perfons in the vicinity, to vifit this tree, to obferve the motions of thefe birds: And when any perfons difturbed their operations, by ftriking violently againft the tree, with their axes, the fwallows would rufh out in millions, and with a great noife. In November, 1791, the top of this tree, was blown down, twenty feet below where the fwallows entered. There has been no appearance of the fwallows fince. Upon cutting down the remainder, an immenle quantity of excrements, quills, and feathers were found; but no appearance or relicks of any nefts.

Another of thefe fwallow trees, was at Bridport. The man who lived the neareft to it, gave this account: The fwallows were firt obferved to come out of the tree, in the fpring; about the time, that the leaves firf began to appear on the trees. From that feafon, they came out in the morning, about half an hour after funrife: They rufhed out like a ftream, as big as the hole in the tree would admit, and afcended in a perpendicular line, until they were above the height of the adjacent trees; then affumed a circular motion, performing their revolutions two or three times, but always in a larger circle, and then difperfed in every direction. A little before fundown, they returned in immenle numbers, forming feveral circular motions, and then defcended like a ftream into the hole, from whence they carne out in the morning. About the middle of September, they were feen entering the tree, for the laft time. Thefe birds were all of the fpecies called the houfe or chimney fwallow.--The tree was a large hollow elm, the hole at which they entered was about forty feet above the ground, and about nine inches diameter. The fwallows made their firft appearance in the fpring, and their laft appear- 
ance in the fall, in the vicinity of this tree; and the neighbouring inhabitants had no doubt, but that the Ewallows continued in it during the winter. A few years ago, a hole was cut at the bottom of the tree : From that time, the fwallows have been gradually forfaking the tree, and have now almolt deferted it.Neither of thefe accounts, are attended with the higheft degree of evidence, which the fubject may admit of: But I am led to believe from them, that the houfe fwallow, in this part of America, generally refides during the winter, in the hollow of trees; and that the ground fwallows, find fecurity in the mud, at the bottom of lakes, rivers, and ponds.

Of the Singing Birds, the following are the moft diftinguifhed, either by the variety of their notes, or by the melody of their found :

The Robin. Turdus migratorius.

Skylark. Alauda alpeftris.

Thrufh. Turdus rufrus.

Thrafher, or Mock Bird. Turdus polyglossos.

Boblincoln. Emberiza oryzivora.

Yellowbird. Fringilla aurea.

Bluebird. Motacilla coerulia.

Wren. Motacilla regulus.

Red winged Blackbird. Turdus niger olis juperné rubentibus.

Catbird. Muscicapa vertice nigra.

Golden Robin, or Goldfinch. Oriolus aureus. Springbird. Fringilla.

Hangbird. Oriolus iEterus.

The only natural mufic, is that of birds. In the uncultivated ftate, and parts of the country, this delightful found is not to be heard. Either difgufted with fo gloomy a feene, or difliking the food in the uncultivated lands, the mufical birds do not deign to dwell in fuch places; or to put forth their melody to the rocks, and to the trees. But no fooner has man difcharged his duty, cut down the trees, and opened the 
the fields to the enlivening influence of the air and the fun, than the birds of harmony repair to the fpot, and give it new charms by the animating accents of their mufic. From break of day until about nine o'clock, the lovely harmony is heard from every quarter. About that time of day, the mufic ceafes. The muficians retire to other employments; and there is no further concert, until next morning. This is one of the molt delightful fcenes, which nature affords : But like mott of our delicate pleafures, it is not to be enionor, but in the cultivated ftate.

A great varir; 0 - birds generally refort to the ponds, rivers, and lakes; which, on that account, are commonly diftinguifhed by the name of Water Fowl. Among thefe aquatic birds, the moft common are The Goofe, three fpecies. Anfer canadenfis.

Duck, eight or ten. Anas.

Teal, two. Anas.

Heron, two. Ardea.

Gull, two. Larus.

Shelldrake, three. Mergus.

Crane. Ardea canadenfis.

Stork. Arciea ciconia.

Loon. Colymbus immer.

Waterhen. Alea artica.

There are many other birds, which do not fall under either of the above defcriptions. Of this kind, the following are the moft common and nu. merous.

The Eagle, two fpecies. Falco.

Hawk, four. Falco.

Owl, three. Strix.

Woodpecker, feven or eight. Picus.

Kingbird. Lanius tyrannu's.

Crow Blackbird. Gracula quifcula.

Cuckow. Cuculus americanus.

Kingfiner. Alcedo alcyon.

Woodcock. Scolopax rufitica.

Woodnipe, 
Wood!nipe. Scolopax fedoa.

Qual. Perdix minor.

Curlew, two. Scolopax

Plover, four. Charadrius.

Wild Turkey. Maleagris gallopavo.

Turtle Dove. Columba carolinenfis.

Whip poor Will. Caprimulgus europaus, B.

Nighthawk. Caprimulgus americanus.

Hedgebird. Mufcicapa canadenfis.

Crolsbill. Loxia curviroflra.

Hummingbird. Trocbilus colubris.

In addition to thefe, there is a mamillary biped, the Bat (vefpertilio murinus:) And a great variety and number of fmall birds, which have never been enumerated, defcribed, or claffed. We meet with them every day in the fields, but they are not diftinguilhed by any proper names.

It is worthy of remark that in the birds of America, nature proceeds from her molt minute and curious, to the moft fublime and magnificent productions. The Hummingbird is the leaf of all birds. The Condior, a bird of Southamerica, in bulk, ftrength, and courage, is the greateft. Both of thefe are peculiar to America. The gradation from the leaft to the greateft, through all the intermediate fteps and degrees, is nicely and beautifully filled up, with an infinite variety of others.

\section{F I S $\mathrm{S}$ H $\mathrm{E}$ S.}

OF the great variety of fifh, which nature has produced in the waters of America, but a fmall part are found in the internal parts of the continent. The largeft collection of waters which we have in Vermont, are the lakes Champlain, Memphremagog, Connecticut river, with the ponds and ftreams connected with them. In thefe waters we have The Sturgeon. Acipenser fiurio.

Salmon, 
Salmon. Salmo.

Salmon Trout. Salmo falar.

Bals. - Perca ocelata.

Pıckerel, or Pıke. Efax lucius.

shad. Clupea alofa.

Atewife. Clupea.

E.l. : Murena anguills.

Trout: Tracta:

Red Perch. Perca furviatalis.

White Pesch. Percalluciaperca.

Pout. Silurus felis.

Shiner. Perca nobivis.

Chub. Perca pbiladelpbica.

Bream. Perca cbryjopter.a.

Bret.l Clupea minima.

Menow.

Sucker.

Dace.:

Migration is not peculiar to the birds : Several kinds of fifhes, have as regular periods of approach, and departure, as the birds of paffage, This is the cafe with the falmon. In the fpring, about the $25^{\text {th }}$ of April, thefe filh begin to pars- up Connecticut river, and proceed to the higheft branches. Aboutthe lane time, or a little later, they are found in Lake Champiain, and the large ftreams which fall into it. So ftrong is this inflingt of migration in the the falmon, thit in pafing up the rivers, they force their parrage over cataracts of feveral feet in height, and in oppofition to the moft rapid currents. They are fometimes feen to make fix or feven attemipts, before they can fucceed to afcend the falls. When they are thus going up in the fpring, they are round arid fat, of an excellent tafte, and flavour. From the firft week in May, to the fecond week in June, they are taken in great numbers. When they arrive at the upper parts of the rivers, they depofit their fparn, and remain there during. the fummer 
feafon; but become very lean, and flaccid. Towards the latter end of September, they refurn to the ocean; but fo much emaciated, that they are not taken, or ufed for food. Some of thefe falmon in the fpring, will weigh thirty five or forty pounds. They migrate only to cold waters. None of them are ever found to the fouth, or weft, of Connecticut river. Thofe that go further to the northward, and pafs up the river St. Lawrence, are generally more large and 1 ich, than thofe which come from the fouthward.

The Salmon Trout, in its form, dimenfions, and appearance, very much refembles the falmon; but the meat is of a finer grain, and of a more delicate afte, and flavour. This trout is found in Lake Champlain, and in the rivers and ponds, which are connected with it. Thefe fifh are taken with the hook and line, like the cod and haddock. Trouts from feven to ten pounds, are common. In a pond at Leicefter in this ftate, fome have been taken which: weighed twenty five pounds: Orhers much larger have been feen leaping out of the water, which the fifherman fuppofed would weigh from thirty five to forty pounds.

The Pike or Pickerelabounds much in Lake Champlain. It is there called by the name of Mufchiiongoe, and grows to a great fize. They are eafily taken with a fpear, and fome of them have weighed forty pounds, and were fix feet in length.

Of the fmall fin, which refide in the brooks and fmall ftreams, the molt numerous and ufelul, are the trout, perch, and fucker. 'The trout, in its colour, form, and tafe, refembles the falmon trout, but is of much fmaller dimenfions. The largeft of them; will not weigh more than two pounds and an half, or ihree pounds. This fith is found in all the freams; $w$ bich have their origin in the mountains; and gencally very near their fources, in the high lands. 
The perch and the fucker are alfo very numerous. and ufeful, and of nearly the fame dimenfions. The moft uncommon inftance, which I have ever feen, of the multiplying power of nature, was in the increale of thele fifh. At Tinmouth, is a brook about twenty. or thirty feet wide, and two or three deep; in which the trout and fucker were to be found of the common frze, and number. A dam was built acrols this ftream, for the purpofe of fupplying water for a fawmill. This dam formed a pond, which covered by eftimation, about a thoufand acres, where the trees were thick, and the foil had never been cultivated. In two or three years, the fifh were multi plied to an incredible number. They were become fo numerous, that at the upper end of the pond, where the brook fell into it, in the ipring the finh are feen running one over another; embaraffed with their own numbers; and unable to efcape from any attempt that is made to take them. They are taken by the hands, at pleafure; and the fwine catch them without difficulty. With a net, the fifhermen often take a bufhel at a draught, and repeat their labour with the fame fuccefs. Carts are loaded with, them, in as hort a time, as the people could gather them up, when thrown upon the banks ; and it is cuftomary to fell them in the fifhing feafon, for a thilling by the buthel. While they have thus increaled in numbers, they are become more than double to their former fize.-This extreme increafe does not feem to be derived from any other caule, than that of collecting the waters in fuch a quantity, as to form the pond; and thus increafe the means of fubfiftence, by carrying the water over a large tract of rich, and uncultivated land. Events of a fimilar nature generally take place, when an artificial pond is made in any part of the country, no: 
before cultivated; and probably from the fame caufe.*

In the production of fifh, nature feems to have been extremely prolific, in every part of America: Their lpecies, their multiplying power, and the age at which they become prolific, are beyond our knowledge, and computation. The brooks, rivers; ponds, and lakes, are every where, ftored with them: The fea coufts are one continued range of fifhing barks, covered with cod, haddock, and other animals of the ocean. 'The wbale is generally efteem:ed the greateft animal, which nature has produced in the water: In the feas of America, this is to be found in its greateft perfection of magnitude and numbers.

Fofil fhells are frequently found at fome difance from the banks of our lakes, rivers, brooks, and meadows. Some have been found on the fides, or rather in the gullies of the mountains. Such productions require a collection of water for their formation. Naturalifts have propofed, many theories and fpeculations, to account for the collection of water in fuch places, where there are now no appearances of the kind.

In their defcent from the mountains, the brooks and rivers mult every where have formed themfelves into lakes, ponds, and fmall collections of water: And.

* 'The number of firh in the rivers of Southamerica, is fully. equal to any thing that takes place, in the northern parts of the continent. "In the Maragnon," fays P. Acugna, "fith are fo plentifl, that, without any art, they may cake then with their hande."

"In the Orinoco," fays P. Gumilla, "befides an infinite va. riety of other finh, corcoifes or turtle abound in fuch numbers, that I cannot find words to exprefs it. I doubt not but that fuch as read my accounc will accule me of exaggeration: But I can atfirm, that it is as dificult to count them, as to count the fands on the bank of that river." Hift. del. Orenogue, ii. c. 22. p. 59. M. de la Condamine contirms their accounts. 
And it was not until after long periods of time, that they could form for themfelve's channels of fuch depth, as to difcharge the waters which had been thus collected. Sorne of thefe ponds were formed on the fides of the mountains, and others overflowed what are now called the meadows; and many of their ancient phenornena yet remain. The waters have long fince forined the channels, by which they are now difcharged into the ocean. - In fuch places, forfil thells are yet found: They are the productions of former times, when thole places were covered by the waters defcending from the mountains; then collected intor quantities for want of natural channels, now drawn off by the depth of the channels which the waters have formed, and confantly rendered more and more deep.

\section{REPTILES ANDINSECTS.}

THAT clafs of animals, which are dintinguifhed by the names of reptiles, and inlects, are numerous in every part of America. They abound the moft, and are of the largeft fize, in the hottent parts of the continent.' In a climate fo cold as that of Verinont, they are comparatively of but a few fpecies, and fmall in their fize; but they exift in great numbers. The following are our

\section{A MPHIBIOUS REPTILES.}

The Turtle, two fpecies. Tej $2 u d$.

Toad. Rane.

Frog, five. : Rane.

Lizard. Lacerlspunctata.

Swift. Lacertífusciata.

There are feveral accounts in natural hiftory, of toads being found in the hearts of trees, and in folid rocks; wholly inclofed, and thut up from the air, 
air, and all appearance of food; and being taken alive, out of lucn fituations. In the Memoirs of the Academy of Sciences, there is an account that in the year $173^{1}$, a load was found in the heart of an old oak near Nantz, without any. vifible entrance to its, habitation. From the fize of the tree, it was concluded, that the toad muf have been confined in that fituation, at leaft eighty or anihundred years.* We have feveral inft nces in Vermont, equally extraordinary. At Windfor, a town joining to Connecticut river, in September, 1790, a living frog was dug up at the depth of nine feet; from the furface of the earth. Stepber, Facabs, Elq; from whom I have this account, informs me, that the place where, this frog was found, was about half a mile from, the riv$e r$, on the intervale lands, which are annually overflowed by its waters. At Caftleton, in the year 1779, the inhabitants were engaged in building a fort, near the centre of the town. Digging into the earth five or fix feet below the furface, they found many frogs, apparently inactive, and fuppofed to be dead. Being expofed to the air, animation foon appeared, and they were found to be alive, and healthy. I have this account from General Clarke, and a Mr. Miulton, who were prefent when thefe frogs were dug up. Upon viewing the $\int_{p}$ ot, it did not appear to me, that it had ever been overflowed with water, but it abounded with fprings. A more remarkable inttance was at Burlington, upon Onion river. In the year 1788, Samuel Lane, Elq; was digging a well near his houle. At the depth of twenty five or thirty feet, from the furface of the earth, the labourers threw out. with their fhovels, fomething which they fufpected to be groundnuts, or fones covered with earth. Upon examining thefe appearances, they were found to be frogs ; to which,

* Smellie's Philofophy of Natural Hiftory, p. 122. 
which, the earth every where adhered. The examination was then made of the earth, in the well, where they were digging. A large number of frogs were found covered with the earth, and fo numerous, that feveral of them were cut in pieces by the fpades of the workmen. Being expofed to the air, they foon became active; but unable to endure the direct rays of the fun, the moft of them perifhed. This account is from Mr. Lane, and Mr. Lawrence one of the workmen, who: were both prefent when the frogs were dug up. From the depth of earth; with which thefe frogs were covered, it cannot be doubted but that they mutt have been covered over in the earth, for many ages, or rather centuries. The appearances denote that the place from whence thefe frogs were taken; was once the bottom of a channel or lake, formed by the waters of Onion river. In digging the fame-rvell, at the depth of forty one feet and an half from the furface, the worktien found the body of a tree eighteen or twenty inches in diameter; partly rotten, but the bingeft part found. The probability is, that both the tree, and the frogs were once at the bottom of 'the channel of a river, or lake; that the waters of Onion river, conftantly bringing-down large quaintities of earth, gradually raifed the bottom: That by the conftant increafe of earth and water, the water was forced over its bounds, and formed for itfelf a new channel or parfage, in its defcent into Lake Champlain.- How vigorous and permanent muft the principle of life be, in this animal !'Frogs placed in a fituation, in which they were perpetually fupplied with moinure, and all wafte and perfpiration from the body prevented, preferve the powcrs of life from age to age! Centuries mut have paffed fince they began to live, in fuch a; fituation; and had that fituation contiriued, nothing appears, but that they would have lived for many centuries yet to come !

$$
\text { SERPENTS. }
$$




\section{S. E R, R, E , N,$T$}

The Rattle Snake. Crotalus borridus. Black Snake. Coluber conflrizior.

Green Snake. Colubes Saurita.

Siriped Snake. Anguis cry's.

Water Adder. Coluber fafciabus.

3. Thefe are all the fpccies of this kind of animals. of which I have any account; and thefe are but fel is dom to be met with in Vermont.

There is a curious phenomenon refpecting twa of thefe fpecies, which feems to deferve further inquiries. The farmers, and other perfons who frequently meet with the rattle; fnake, and, with the hlack fnake, feem univerfally to beliẹve that each of thefe animals, have a power, of fafcination; or as it is commonly expreffed, of cbarming birds, and ocher fmall animals. The account which is generaliy. given, is this : The fnake lies ftretched out his full length, in fome open place; his head raifed. eight or ten inches from the ground; his colours glow with their greatent brightnefs; his eyes playt with an uncommon brilliancy, and fire; and are fteadily fixed on the enchanted animal.-During: this feene, the bird appears to be in the greateft dif:trefs; is conftantly putting forth the mott mournful accents; at the faine time, is performing a number of irregular circular motions; and at the end of each, approaches nearer to the fnake: This fcene continues, and is inceffantly repeated, until the bird, without any power to efcape, comes within the reach of the voracious jaws of the ferpent, when it. is infantly feized: But if the fnake is attacked, or fo difurbed during the operation, that his attention is turned anotber way, the charm is broken;: and the bird recovering his liberty, immediately fliks off.I have never myfelf feen any thing like this fafcinating 


\section{HISTORY OF VERMONT.}

ing fcene; but I have had accounts exactly fimilar, from more than a dozen perfons, who?e integrity $I$ cannot in the fmalleft degree, call in queftion. There is room, however, for miltakes in fuch kind of obfervations; and in molt of them, the fnake was difturbed, before the fcene was finithed. That there is fornething curious in thefe appearances, cannot be doubted. But whether thefe fnakes have fuch powers, or by what caufes fuch events are produced, feems to require more accurate obfervations, and a inore philofophical inveftigation.

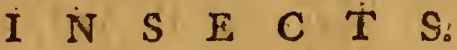

The infects are too minute, and numerois, to be particularly defcribed. The moft common are the beetle, grafshopper, cricket, butterfly, firefly, blackfly, moth, flea, ant, mufqueto, fpider, hoinet, wafp, bumble bee, honey bee, various kinds of bugs, and feveral fpecies of worms. Of thefe the mufqueto is the moft troubleforne. The weavil, the Heffian fly, and the locuft; are not known in this part of the continent.

Of the bee; there is a fpecies which is gerierally called with us, the bumble bee. This is indigenous to the country; and much larger than the common bee: It forms a neft upon the ground; and produces a fpecies of horiey; in tranfparency, bearity, and fweetnefs, fully equal to that of the honey bee; but much lefs in quantity. Whether the honey bee is a native of the country, feemis to be viewed by fome as uncertain. I do not find rnuch reafor to doubt, but that it was in America, before the Eu. ropcans made their firf fettlements in the country. From the piEtures and tribute rolls of the Mexicans, it appears that the honey bee was known, and that honey was one part of the annual tribute which was paid to their emperors before the arrival of the Spar.R. inids. 
iards. Clavigero in his hillory of Mexico, confirms thefo accounts; and mentions fix kinds of bees which make honey; two of which have ftings, and one in all relpeds agrces with the honey bee of Europe. A fpecies of the honey bee, but without flings, was found in Chiapa, and Yucatan. The fame according to Margrave; was found in Brafil. In 1540, among the provifions of the natives of Florida, " a pot full of honie of bees," was found. by Soto.-From thefe accounts, it is not to be doubted, but that the honey bee was indigenous, and had fpread over the empire of Mexico. To the eaft, it had advanced as far as Flosida: And to the fouth, to Yucatan, and the country of Brafil. To an immenfe country then, the honey bee was indigenous, and common.- There was no caufe in the nature of the animal, or of the climate, to prevent their fpreading to the northward. They live in the hollow trees in the woods of Vermont, from year to year; and are always found, of their full dimenfions, vigorous, and plentifully fupplied with hovey; and they bear the cold of our winters, much better in the hollow of a large tree, than in any of our artificial bee hives. They live and abound in Rufra, where the climate is much more fevere, than it is in this part of America: They would therefore naturally extend, and fpread along the country, where they could find the means of fubintence, and a climate not unfuited to their fupport. It has always been found far beyond the Engligh fettlements. From our earlieft acquaintance with Ialse Champlain, it was to be found in the open lands, along thole flores; at the diffance of an hundred miles from the Englifh or French fettlements; and long before thofe fettlements had begun to attend to the cultivation of this animal: And from the firft fettlement of Newengland, hanting for their nefts has been a farourite and profitable amulement.-But as the 
chief food of the bee is from the bloffoms and flowers of plants, it does not multiply fo faft in the uncultivated parts of the country, as where the improvements of agriculture and gardening, are conftantly producing a greater variety, and number of vegetables.

To the tribes of reptiles and infects, we have affixed the idea of lomething, unplealant, diminutive, or odious. The defigns, the wifdom, and the power of the Creator, are not to be eftimated by fuch feelings, fears, and prejudices. The reptile, the infect, the fifh, the bird, and the quadruped, one as much as the other, denote wildom, power, and defign, in the author of nature : And they are alike evidences, and inftances, of the power of animated nature, in the different parts of the earth. We may therefore as jult. ly and clearly deduce the energy and force of animated nature in any country, from the number and magnitude of the infects, as from the fpecies and dimenfions of any other animals. The European philolophers have dwelt with wonder and aftonifhment, on the numbers and fize of thefe animals in America. The facts are juftly ftated, in feveral of their accounts; and they ought to have concluded from them, that the foil was uncommonly rich, fertile, and luxuriant. Anxious to find marks of degradation in America, they have almoft univerfally advanced a contrary conclufion : That this prolific power of nature, denoted an uncommon corruption, and degradation of climate. No conclufion was ever further from the truth, or more remote from probability. It is only a rich foil, and a temperate climate, which can produce what they call a rank vegetation, or numerous reptiles and infects, of the largeft fize.

From this imperfeat view of our quadrupeds, birds, filkes, and infects, inftead of finding nature but weals and feeble in America, as M. de Buffon 
332 THE NATURAL AND CIVIL

has fuppoled; * her animals appear to be marked with an energy, and a magnitude, fuperiour to what is found in Europe ; and equalled only, by the mag nificent and vigorous productions of Afia.

" La nature vivante eft beaucoup moins agiffante beaucoap fgoirs forte.". HiAt. Nat, yviii. 123. edit. Paris, 1964. 


\section{H A P. VII.}

Original InhaBitants. - The Employments, Civil Government, Sysem of War, Education, Monners, and Cuftoms of the Indians; the Advaniages, and Difadvantages of the Savage State.

IN the formation of the mountains, vivers, vegetables, and animals, the powers of nature appear to rife in a ftcady and beautiful progrefs. This progrefs feems to be completed in the produc: tion of a rational, moral, and accountable animal. This animal is Man: And he evidently appears in every part of the globe, to be at the head of all the productions of nature: But the men of different countries and nations, appear to be very different from one another.

The original inhabitants of this country were the Indians: Thefe were the only fpecies or kind of men, that had fpread over America. It will be more difficult to give a juft account of the Man of Ameri$c a$, than to defcribe its vegetables, and animals. The latter are fubject to ftated, and invariable laws; they pafs through but few changes and variations, and are always to be found in that ftate, in which nature placed them. Man is fubject to a great variety of alteration, and improvement. In his rudeft and moft fimple ftate, he appears but little fuperiour to the brute; in his higheft improvement and polifh of thanners, he appears at an infinite remove from the 
bare animal; and in all the ftages of his progrels from the one ftate to the other, he paffes through an endle fs variety of fituations and circumftances, which are conftantly giving a new appearance to his capacity, powers, pallions, manners, and purfuits. The natural hiftory of man is therefore the molt difficult, but it is alfo the moft ufeful and important fubject we can contemplate. In examining the hiftory of the Indian of America, we fhall find man in the molt fimple mode, and unimproved ftate, in which he has ever been placed, or viewed.*

Appearance and Countenance. - The appearance of the Indians was different from any, under which man had ever been viewed before. The colour of their fkin is of a reddifh brown, nearly re. fembling the colour of copper, but rather darker. Their faces are broad, the nole appears flattifh, their eyes black, fmall, and very active. The hair of their keads is always black, coarfe, long, and perfectly flraight; and they generally appear without any beard. The men are taller than the Europeans, but rarely corpulent; and their bodies appear to be firm, frong, and well proportioned. Their featires are regular andwell adjufted, but their countenance difcovers fomething wild, fierce, and fullen. None of them are feen crooked, mutilated, or deformed; defective in any of their lenfes, or deficient in any of their bodily organs; but ftraight, well built, and robuft. In the appearance, afpect, and countenance of the Indians, there is an uncommon uniformity, and refemblance. It is the fame in all climates, and in all the tribes of America. It does not vary with

- The following accovint relates chiefly to the Indians in the northern parts of America. I have received much afiltance from the writing 3 of Dr. Robertfon, and other authors. But the auchorities on which the accounts are founded, are chielly the selations of thofe perfons who have lived among tho Indians, and besn intimately acguainted with them. 
with heat, cold, fituation, employment, or other circumftances; but the Indian countenance has the fame combination of features, and peculiarity of afpect, in every part of America.

EMPLOYMENT, AND METIOD OP PROCURING SUBSISTENCE. - The food proper for man, is to be: found in every part of the earth. But the means. and the method of procuring it, are different among different nations, and in different ftages of fociety.The favages of Northamerica had difcovered the properties and effects of thofe feeds, berries, and: roots, which the earth fpontaneoully produces; and. one part of their food was derived from this fource.. Fifhing was another method which they ufed to procure fubfiftence. The great plenty and variety of filh, with which the rivers of America abounded, rendered this kind of provifion eafy to be procured. and of great ufe. The Indian had acquired much fkill and addrefs, in his method of catching the fifh; and he was accuftomed to dry, and moke them, in order to preferve them. The falls of rivers were the places, to which they moft reforted for this purpofe: And moft of thefe falls were the places, where fome of their tribes or fmall companies refrded: Ard. they were generally diftinguifhed by fome particular Indian name. - A more general and effectual method of fupport, was hunting. "The fruits which the. earth fpontaneouny produced, were but few, and of thort continuance. A few tribes only could be accommodated, by the vicinity and convenience of a river: But game was every where to be found. The bear, the deer, the beaver, the fox, and other animals, were in great numbers, and in every part of the northern continent. From thefe, the Indian derived his molt fure, and plentiful fupport. But this method of procuring,food, required great efforts of invertion, and activity. The ftrength, the fiercenefs, and the fwiftnefs of the wild animals, the fee. blenels 
blenefs of the weapons, the bow, arrow, and clubi, with which the favage attacked them, joined to make the bufinefs of the hunter laborious and diffcult; and called forth all the active powers of the favage. And here, he appeared to the greateft advantage; fertile in invention, fagacious in diftinguifhing and obferving, nice and accurate in tracing the animal ; indefatigable, and perfevering in the purfuit. An employment which thus gave exertion to all the invention, courage, force, and vigor of the man, naturally became, the molt honourable employment: And the moft dexterous hunter became the moft diftinguifhed favage of the tribe.-To thefe methods of procuring food, were added fome feeble attempts in agriculture. Indian corn, beans, pompions, and fqualhes, were the only plants they cultivated. The culture of thefe was wholly in the hands of the women. Without the ufe and knowledge of any of the domeftic animals, altogether deftitute of the proper infrumerit's of hufbandry, their efforts were weak: and languid; and the fupplies they derived this way, were but fmall:

Thefe were all the methods of procuring food, with which the Indians were acquainted. They afforded them but a fcanty and precarious fupport: When the game was plenty, and the hunter fuccelsful, they had an abundance of food. TVhen the feafon of the year was unfavourable, atd their fuc: cefs but frnall, they were reduced to fcarcity and wart. Their fufferings this way, were fometimes extremely fevere. And there was no year, in which they were not fubject to thele extremes; of great plenty, and fevere famine.

The appetite of the Indian conformed to this ftate of things. "In the feafons of plenty, the favage indulged himfelf to great excels: In the time of famine, the Indian bore his hunger with aftonifhing patience, and firmnels. So accultomed was he to this 
irregular method of living, that excefs and famine were equally familiar to him; and his conftitution and health remained firm and vigorous, under the extremes of both.

From this fituation and employment of the Indian, all the regulations, cufoms, advantages, and difadvanroges, of the favage ftate, were derived.

Socretr. - When any confiderable number of the human race fubfint near each other, they will always combine in fome form of fociety: Mutual wants, dangers, dependencies, interefts, and benefits, operating with the appetite man has for fociety, will not fail to produce this effect. The fituation and employment of the Indians, determined what the nature and extent of this fociety muft be, among them. The chief fource of fubfiftence among them, was hunting. On this account, a large territory became neceffary for the fupport of a fmall number of people. Like the game on which they fubfint, they muft be difperfed over a large tract of country', or they cannot procure food. In this ftage of fociety, the extent of it is derived from its fituation. Its territory mut be large, the number of people will be fmall, and all hoftile tribes muft be kept at fuch a diftance, as not to encroach upon the territory or the game. This was the ftate, in which the favages were found. Divided into a number of tribes, fmall in the number of people, large in the extent of territory, and generally unfriendly and hoftile to each other.

Nature of their Civil Government. From this nate of fociety, arofe a fpecies and form of government peculiar to the Indians. - The $\dot{d} \int f g n$ and object of government among the favages, was not the property, fecurity, or conduct of the individual ; but the property, and fafety of the tribe. The ides of property is fuggefted by nature ; and was clear, diftinet, and juft, in the mind of the ruden Indian. The firh in the river, and the game in the foren, 
were not the produet of his care or labour; and he had no idea that they beloriged to him, more than to any other individual. But when they were acquired by his perfonal exertion, no other favage doubted but that they were become his particular and exclufive property. The river, or the foreft, from which they were taken, were not perfonal but public property: They belonged to the tribe. No individual claimed a right to them, in preference to, or exclufive of others. Thefe were the property: of the tribe, be longing cqually to all, and to which all had a right to repair in queft of fubfiftence, the equal and common privilege. When the Indian builded his houfe, or planted his corn, no one had a right to moleft him ;. the houfe and the corn became his. When he relinquifhed his pofferfion, any other of the tribe bad. a right to take poffeftion, and purfue the fame employment that he had cone. The fruits of their own. labour and induftry, was always the property of the individual: The river, the foreft, the hunting ground, the land or the territory, was the property of the tribe. The former was of fo fimple a nature, fo well underflood, and fo unirerfally agreed to, that few controverfies could ever arife about it ; common cuftom and confent was fuficient to adjuft and regulate every thing of this nature. The latter contained all the property, the means of fubfifence, and that on which the whole tribe depended for their exiftence. This was the great object and aim of their government; to protce: and defend that, on which the whole tribe fubfined.- In fuch a $\mathrm{fate}$ of fociety, the injuries that would be done to individuals would not be many in their number, or ofien of fuch a kind, as to eadanger the exiftence or fovereignty of the tribe. The right of redreffing them, was therefore left in private hands. This has always been the cafe, in the infancy of fociety and governesent, L injurics were done, if blood was fhed, 
it belonged to the friends and family of the injured perfon to feek redrefs. If the chiefs interpoled, it was only by way of counfel and advice. The friends of the injured perfon might accept of their advice, or of the reparation offered by the aggreftor, or they might reject it:: If it was accepted, all was fettled in a quiet and friendly manner: If rejected, nothing remained but to purfue the aggreffor with a revenge and rage, that aimed at nothing lefs than de Atruction and death.

The form and manner of the Indian government. was the moft fimple that can be contrived, or imagined. There was no:king, nobility, lords, or houfe of reprefentatives, among them. The whole tribe affembled together in their public councils. Deftitute of writings, records, and hiftory, to preferve the memory of their public tranfactions; their moft aged men became the depofitories, of what may be gath ered from experience, obfervation, and a knowledge of their former tranfactions. It is by them that the debates and confultations are chiefly carried on. Their councils are flow, folemn, and deliberate. Ev ery circumftance that they can forefee, is taken into confideration. The probable advartages and difo advantages of every meafure, are examined and weighed. All the profpects of fuccers and difappointment, are revolved in their debates; and noth. ing is omitted, which occurs to their views or expectations. The whole bufnefs is a fcene of confultation, and advice. And the advice has no other force or authority, than what is derived from its luppofed wifdom, fitnefs, and propriety.

The frength or power of the government, is placed wholly in the public fentiment. The chief has no authority to enforce his counfels, or compel to his meafures. He is fed and clothed like the reft of the tribe. His houfe and furniture are the fame as thofe of others. There is no appearance, or mark 
of diftinction: No ceremony, or form of induction into office: No enfigns or tokens of fuperiority, or power. In every external circumftance, the chiefs are upon a level with the reft of the tribe: And that only which gives weight and authority to their advice, is the public opinion of their fuperiour wifdom and experience. - Their laws ftand on the fame foundation. There was no written law, record, or rule of conduct. No public precedent, eftablifhed courts, forms or modes of proceeding. The caules and occafions of contention were fo few, that they did not much affeet the tribe. And when the chiefs interpoled in the concerns of individuals, it was not to compel, but only to counfel and adrife them. The public opinion pointed out what was right, fit, and proper to be efteemed laws and rulcs of conduct. Thefe rules or laws derived from nature, were feldom wrong, obfcure, or inconfiftent; but generally plain, clear, and ufeful.-Their penalties and punifhments were derived from the fame fource. Lofs of character, and reputation, difgrace, exclufion from the tribe, and death, were the punifhments to which offenders were expofed, according to the nature and aggravation of their crimes. Thefe punifhments were not defcribed, and affigned to a particular crime by a written law ; but they refted upon the public opinion of the tribe, and derived great force and power from it. An offender who had been greatly and deeply guilty, fled from the tribe, as the only way to fafety, peace, and reft.

There was a fitness and propriety in this government, or rather, it was fully adequate to its end and defign, and to the fituation and fate of the favage. A modern ftatefman would fmile at this idea of Indian government : find becaufe he could find no written confitution, or bill of rights, no mutual checks, and ballances, accountability and refponfibility, pronounce it weak, foolifh, and contemptible. 
But it was evidently derived from the dictates of nature, and well adapted to the ftate and fituation of the favage. The idea of property was fo plain and clear, and the objects to which it related were fo few and fimple, that there was no need of a code of laws to defcribe and define it. The rights of the individual, his freedom and liberty, were fo ftrongly felt, and fo univerfally acknowledged, that no perfon dared to invade them. The crimes of the vicious received a juft and a full punifhment, in the difgrace, contempt, and danger, they brought upon the guilty. The individual had all the fecurity, in the public fentiment, cultom, and habit, that government can any where afford him. All that was to be defended was the territory, the interelt, the independence, and fovereignty of the tribe ; and every part of the government was adapted and defigned to form, to animate, and to inflarme, a national firit of vigour and independence.

Agreeably to its nature and defign, the tendency and effect of the favage government, was equality, freedom, and independence, among all the members of the tribe. In refpect to rights and privileges, the favage knew of no fuperiour. Of abafement, humiliation, dependence, or fervitude, he had no idea. Depending on his own exertions for food and raiment, he had never looked to another for affiftance, promotion, or wealth. When the intereft of the tribe was in queftion, or in danger, the wifdom and experience of years was confulted, to ad. vife and determine : And their counfels became matters of great refpect. But conftraint, compulfion, and force, was the object of the higheft deteftation and horror. Every meafure of the government tended to confirm and increafe the fpirit of freedom, equality, and independence, and to render it ftrong, fierce, and permanent, through tho whole tribe. 
SYSTEM OF WAR AMONG THE INDIANS.-The civil regulations of the favages were all defigned to qualify and prepare them for war. Among the caules that lead to this, an oppolition of interefts, was the mof common and powerfal. No people ever had more clear, or more jult ideas of their own rights and property, than the Indians. They not only underftood their own perfonal rights, but they were perfectly well acquainted with the rights and property, that were vefted in the tribe. Each tribe claimed the foil in their own domains. This right was viewed as complete, perfect, and exclufive: Such as entitled them to the full and entire pofferfion ; and to oppofe by force and violence, all encroachments upon the foil, or gáme, in any part of their territories. The bounds of thefe territories were extenfive, and ill defined. Real or fuppofed encroachments and injuries, were conftantly taking place. Hence arofe innumerable fubjects of difpute and controverfy, which eafily inflamed the Fercenefs of the favage temper, and brought on muttal injuries, reproaches, hoftilities, and war. In this ftate, moft of the Indian tribes were found. Intereft had become a fource of difcord, among the neighbouring tribes. From this caufe, arofe molt of their inveterate and perpetual wars.

The manner in which the Indians carry on their wars, is very different from that of civilized nations. To defend themfelves againft an enemy, they have no other fortifcation but an irregular kind of fortrefs, which they call a caftle or fat. It confifted of a fquare without baftions, furrounded with pallafadoes. This was erected where the moft confidera. ble number of the tribe refided, and was defigned as an afylum for their old men, their women, and children, while the reft of the tribe were gone out to war.-The weapons of the Indian were a club made of hard wood, a bow and arrow. Thus armed, the 
Indian takes with him a fmall bag of corn, and is cumpletely equipped for a campaign. When he takes the field, it is with fuch a number of warriors as the tribe can fupply. During their march, they are difperfed in ftraggling companies, that they may better fupply themfelves by hunting.-When they ape proach near to the enemies' frontiers, their troops are more collected: All is then caution, Atratagem, fecrecy, and ambufcade. Their employment as hunters has taught them great addrefs and vigilance, in following and furprifing the game. Their mode of war is the fame, as that of hunting. With greas ingeruity, they will find and follow the track of their enemies: With a furprifing patience and perfeverance, they will wait for the moment, when they find him the leat able to defend himfelf. And when they can find an enemy unprepared, they make their attack with great fury, and with pretty fure fuccels. In their battles they always endeavour to fecure themfelves behind the trees or rocks, and never meet their enemy in the open field, or upon equal te:ms, if they can avoid it. The method of the E.uropearis, of deciding a battle in the open field, they regard as extreme folly and want of prudence. Their eftabliffed maxims are to obtain a fuperiority in fituation, numbers, concealment, or fome other circumftance before the battle: In this way, to preferve the lives of their own party, and deftroy their ene: mies, with as little lors as poffible to themfelves. A victory obtained with the lofs of many of their own party, is a matter of grief and difgrace, rather than: of exultation: And it is no honour to fall in the field of battle, but viewed rather as an evidence of want of wifdom, difcernment, and circumfpection.When the attack is to be made, nothing can exceed. the courage and impetuofity of the favage. The onfet begins with a general outcry, terminating in a univerfal ycll. of all the founds that difcord has produced, 
produced, the Indian warwhoop is the mof awful and horrid. It is defigned and adapted to increafo the ardor of thofe who make the attack, and to carry terror and horror into the feelings of thofe, on whom the attack is made. The Indians immediately comeforward, and begin the fcene of outrage and deatli. All is then a fcene of fury, impetuofity, and ven. geance. So great is the rage of the favage, that he has no regard to difcipline, fubordination, and order. Revenge, takes an entire poffeffion of his foul : Forgetful of all order, regardlefs of difcipline and danger, he aims only to butcher and deftroy. - If the Indians remain mafters of the field, they always itrip and fcalp the dead. Leaving the bodies of their enemies, naked, unburied, and often mangled, they carry off the plunder and fcalps; and make a very fwift and fudden retreat. Upon their approach to their own tribe, a herald is fent forward to announce the event: The tribe is collected, and the conquerors make their entry with their enfigns of triumph : The fcalps ftretched upon a bow, and elevated upon a pole, are carried before them, as the tokens of their yalour and fuccefs, and monuments of the vengeance they have inflicted upon the enemies of their country.

The prifoners which they have taken, make an important part of their triumph. The favages are anxious to take as many of thefe as poffible. During their march, they are generally treated with a degree of humanity and kindnefs; but the greatelt care is taken to prevent their efcape. When they arrive at the place of their deftination, the old men, women, and children of the Indian tribe, form themfelves into two lines, through which the prifoners muft run the gantlet to the village. If the prifoner is young, active, and a good runner, he makes his way through the lines without receiving much injury. If he is weak, old, and infrm, he receires much damage by the blows, fripes, and bruifes, he receives. 


\section{HISTORY OF VERMONT.}

receives. When this fcene is finifhed the prifoners are conducted to the village, treated with apparent good humour, and fed as well as the Indians' fare admits.

To the village thus affembled, the head warrior of the party relates every particular of the expedition. When he mentions their loffes, a bitter grief and forrow appears in the whole affembly. When he pronounces the names of the dead, their wives, relations, and friends, put forth the moft bitter thrieks, and cries. But no one alks any queftion, or interrupts the fyeaker with any inquiry. The laft ceremony is to proclaim the victory. Every individual forgets his own lors and misfortune, and joins in the triumph of his nation: Their tears ceafe, and with one of the moft unaccountable tranfitions in human nature, they pafs at once from the bitternefs of forrow to all the extravagance of joy. The whole concludes with a favage feaft, fongs, and dance:

The fate of the prifoners is next to be decided. The elders and chiefs affemble and deliberate concerning their deftiny: The women and children are difpofed of, according to the plealure of their captors; but they are feldom or never put to torture, or death. Of the men, fome are appointed to fupply the places of fuch Indians as have fallen in battle. Thefe are delivered to their friends and relations, and if they are received by them; they have no fufferings to fear: They are adopted into the family, and fucceed to all the privileges of the deceafed; and are efteemed as friends, brothers, and near relations. But if they are not received and admitted into the family, or if they are deflined to be put to death, a moft dintrefing and horrid fcene enfues.

A ftake is fixed firmly in the ground. At the diftance of eight or ten lect, dry wood, leaves, and faggots, are plared in a circie round the ftake: And

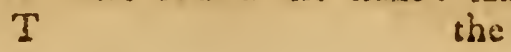


the whole village is collected, to bear their part in the tragedy, which is to enfue. The prifoner is led to the ftake, and tied to it by his hands, in fuch a manner that he may move freely round it. Fire is fet to the wood, that as it runs round the circle, the unháppy victim may be forced to run the fame way. As the fufferings of the prifoner begin to become fevere, the acclamations of the fpectators begin. The men, women, and children, ftrive to essceed each other, in finding out new and keener methods of torment. Some apply red hot irons, others ftab and cut with their knives, others mangle and tear off the flefh, others again bite off the nails. and joints; or twift and tear the finews. Every fpecies and degree of cruelty, that favage rancour and revenge can invent and apply, is tried upon the wretched lufferer. But great care is taken that the vital parts may not be fo injured, as to bring the torments. of the viaim to a fpeedy end. - In this horrid fituation, the fufferer is undaunted and intrepid. He reviles and infults his tormentors. He aceufes them. of cowardice, meannefs, and want of fpirit ; as ignorant, unfkilful, and deftitute of ingenuity and invention in the art of tormenting. Not a groan, a figh, a tear, or a forrowful look, is fuffered to efcape him. To infult his tormentors, to difplay un. daunted and unalterable fortitude in this dreadful fituation is the moft noble of all the triumphs of the warrior. IVith an cinaltered countenance, and with the decifive tone of dignity and fuperiour importance, the hero proceeds with great calmnefs to fing the fong of his death-" Intrepid and brave, I feel no pain, and I fear no torture. I have flain, I have conquered, I have bumt mine enemies; and my countrymen will avenge my blood. Ye are a na. tion of dogs, of cowards, and women. Ye know not how to conguer, to fuffer, or to torture. Prolong and increale my torments, that ye may learn from 
my example how to fuffer and behave like men !" With fuch unconquerable magnanimity and fortitude, the fufferer perfeveres under every method of torment and torture. Wearied with cruelty, and tired with tormenting a man whofe fortitude they cannot move, one of the chiefs in a rage concludes the fcene, by knocking the prifoner on the head, or ftabbing him to the heart.

Thefe fcenes however were not common. They feem to have been kind of honours, referved for the warriors; and were the trials of their courage and fortitude. And nothing was efteemed more bafe and ignominious, than to Thrink from them, or to thew any fenfe of fear or pain under them.

When the prifoners were adopted into the tribe of the conquerors, nothing could exceed the kindnefs and affection, with which they were treated. All diftinction of tribes was forgot; they held the fame rank as the deceafed perfon, whofe place they filled: and were treated with all the tendernefs due to the hufband, the brother, the child, or friend. And it was generally the cafe, that the favages avoided abufe and cruelty to the women and children, that fell into their hands.

The Indian method of carrying on a war, was fo contrary to the maxims and cuftoms of all civilized nations, that fome of the European writers, judging from their own cuftoms, have concluded it was founded on cowardice, and arofe from an ignoble and timid fpirit, afraid to meet its oppofers on equal ground, and depending wholly on craft, and not at all on courage and firmefs of mind. No conclufion was ever further from the truth. When placed in a crit ical and dangerous fituation, no people ever difcovered more valour, firmnels, and intrepidity. When fubdued, an Indian was never known to atk for his life. When compelled to fuffer, the Indian bore it with a feadinefs, a fortitude, and a magnanimity,

unknown 
unknown to all other nations; and of which, thero are no examples in the hiftory of war.-His method of war did not arife from a fenfe and fear of danger; he was well acquainted, and always in the midn of this; but it arofe from his fituation and employment, and was perfectly well adapted to it. From his fituation and employment as an hunter, he acquired the art of ambulcade and furprize; and the method with which he could beft fucceed in taking his game, he found to be the moft luccefsful to enfnare and overcome his enemy. The fituation and ftate of the country, overfpread with thick forefts, lead to the fame method. The fituation of the tribe, fcattered and difperfed in the woods, fuggefted the fame idea. The method of fighting could not be in the open fields, but among the trees. find he wifely placed the point of honour, in the public good; where the profpect and the probability of his fuccefs lay. Had the honour of the Indian warrior been placed, in couring fame and victory in the open field, the whole tribe would have been deftroyen by the effufion of blood that rnuf have fucceeded. His maxims therefore were better chofen, and they were fuch as every circumftance in his fituation and employment, naturally led him to: Not in an ufelefs oftentation of daring courage and boldnets, but in the public utility and advantage. So far as an enterprize depended on fecrecy, fubtlety, furprize, and impetuofity, the Indian method of war feems to have been fully equal to the European. 'The Spaniards, the French, the Englifi, and the States of America, have had many and painful proofs of their addrefs and prowels in this method. But when a fort was erected, or a fmall fortification to be carried, the Indian method of war wholly failed. Neither their arms, their arts, or their cuftoms, were of any avail here: Wholly unacquainted with the art of fortiffcation, they could neither erect, or take 
a fort of any itrength. When the Europeans had once got polfefilion of any part of their country, and erected a friall fortification in their territories, they held it by a fure poffefion. The favages were wholly unable to difpoilefs them by their method of war, and nothing was left for them but to retreat further into the forefts. In this way the Englifh, and French were making conftant advances into their country; and their art of war afforded them no fufficient means, either to prevent or to redrefs it. But when the Europeans followed them into the woods, where their Arength and art might be employed to advantage, the Indians generally furprifed and defeated their armies, with great havoc and flaughter.

Eoucition. - The fubliftence and lafety of the tribe depended fo much upon the hunter, and warrjor, that thefe became of courfe the molt neceffary, ufeful, and honourable profeffions. When in purfuit of food, the young men put themfelves under the direction of the moft noted and fuccersful hunter. Going forth to war, they followed the molt renowned and fuccefsful warrior. Eminence in thele profeffions was the fureft way to fubfiftence, to diftinction, to honour, and renown. This was the balis, and formed the whole bufinefs of education, among the favages. To train up the youth to addrefs and dexterity in hunting; to make him patient, firm, perfevering, in hardhip and fuffering; inveterate, fierce, and intrepid, in deftroying his enemies; was the chief aim and defign of the parent. Every thing that had no connexion with this, was neglected and defpiled. The arts of acquiring knowledge, governing the paffions, refining the manners, and cultivating improvements, were unknown and undefred by the favage." He never corrected or reftrained his child, taught him to moderate his appetites and pa?fions, to fubmit to parental, or any other authority: On the contrary he was trained up to take care of himfelf, 
himfelf, to gratify every inclination and appetite, and to look for food and honour in his own exertions, independence, and fuperiority. The parent wifhed and aimed to form his fon to hardhip and danger, so bear faligue, famine, and torture, to enfnare and take the game, and to carry deftruction and vengeance upon his enemies. To this plan of education, the whole aim and conduct, the inftruction, the manners, and the example of the parent, was directed: The only aim and defign, was to make the youth an able and accomplifhed bunter, and warrjor. Neither the views of the parent, or the wifhes and aims of the child, cver rofe any higher, or excended any further than this.

Next to the civil and military regulations, the eufoms and mowners of the Indians claim our attenion. The cufloms and manners of a nation, always conftitute a diftinguifhing part of the national character; and as they vary with the progrefs of fociety, they ferve to afcertain, and mark the different ftages of it. In feveral refpects, the manners and cuftoms of the Indians were different from thofe of other people, and are marked with a fingularity peculiar to the favage ftate.

GRAVITY OE APREARARCE.-A gravity of appearance and countenance always engages our attention, when we are in the company of the Indians. Placed in a fituation of conftant diffuculty and danFer, depending aitogether upon himfelf, and having ever before him purfuits, which to him are of the highen importance, the lavage becomes extremely grave and ferious. Evcry thing in his appearance and behaviour, is marked with this gravity of afpeet. IIis bebaviour to thofe around him, is decent and moje?t. His words are few and fignificant, and generally upon fome matter of bufinefs; fcarcely ever for merriment or diverfion. So great is their ladit of gravity, ferioulnels, and filence, that it rather 
mether bears the appearance of melancholy and fad. nefs.

TREATMENT OF WOMEN.-A promifcuous in. tercourfe between the fexes, farcely ever took place among the human race. The relation of hulband and wife, has been every where anderftood, adapt ed, and acknowledged; and this was univerfally the cafe among all the tribes of the American Indians. Where the difficulty of procuring fubfiftence was. not eafily to be removed, the man had generally but one wife. Where the means of fubffence, were in great plenty, and cafily to be attained, the favage had' often a plurality of wives. But in general, the Indian family confifted of one man and woman, and their children. This union generally fubfifted during the lives of the parties; but if it became a matter of choice to feparate, the marriage union was difolved, and no caufe or ceremony was neceffary, but choice and confent.-It is not until the refinements of fo. ciety have taken place, that women acquire the rank, confequence, and importance, to which they are fo juflly entitled. To defoife, to degrade, and to abufe them, has been the praetice of every nation while it remained in the favage ftate. Without tendernefs, without delicacy, without refinement, the heart of the favage does not look for pleafure in the beauty, chaftity, and modefty; in the tendernefs, delicacy, and affection; or in the attachment, converfation, and refined manners of the female; but is the labours and menial fervices the is able to perform. In this ftage of fociety, marriage is not a tender attachment, or a union of refined and delicate affections between the fexes; but altogether an animal inclination, the bare inftinet of nature. Plac. ing all excellency in ftrength and courage, the male views the female as cvery way inferiour to himfelf not fitted for honourable employments, but defined: to inferiour purpoles and fervises, of confequence. 
the condition of women in the favage ftate becomes degraded, inortifying, and fubject to fervitude. The favage affigns to his wife the care of the children, the bufinefs of labouring in the field, and all the fervices of domeftic care and difficulty. Among the Indians, this degradation of the female was carried to its greateft extreme. Every thing moft valuable in food, drefs, and ornament, was referved for the man :. The moft laborious, fatiguing, and difagreeable fervices, were affigned to the women. Doomed to inceffant toil and flavery, the women perform their perpetual tafks without pity, without compaffion, without praife, and without the gratitude of their hufbands. To this degraded unhappy ftate, were the women reduced among all the Indian tribes.

DrEss.- The fame purfuit that fupplied the Indian with food, provided alfo his clothing. This was made of the Ikins and furs of the animals they took in hunting: Thefe ferved the purpofes of covering, and modefty, none of the northern Indians ever appearing naked.-In thofe nations where opulence and luxury prevail, drefs becomes a complicated, a profitable, and a curious art : And beauty acquires new force and power, from ornament and fafhion. Hence it becomes a moft lucrative bufinels in polifhed focieties, to irvent and fupply the modes, fafhions, materials, and ornaments for drefs.-The favage was not without his tafte for ornament, and fafhion. His hair was dreffed in many, and in very. fingular forms. His nofe and ears had pieces of gold, thells, or thining ftones, affixed to them. His face and $f$ in were painted, with different colours and figures. And much time was fpent to give his countenance the afpect, he aimed at. The defign of his drefs and ornament was not gallantry, to recommend himfelf to the female, but rather war; to appear the object of dignity, majefty, and fear. And what was extremely fingular, all the finery and decoration 
oration of drefs, was referved for the man. The Thare that fell to the woman, was only that which remained, when her hufband was completely decked. When he was about to join the council of his nation, or was going forth to war, he was moft of all folicitous to appear in his richeft ornaments, and fineft decorations. - A cuftom prevailed among the Indians, of rubbing and anointing their bodies with greafe, oil, and different kinds of gums. Thefe were often mixed with different colours, and formed a very durable paint, or kind of varnifh. This may. properly be eftimated as a part of the Indian drefs. And it was well adapted to defend the body, againit the extreme moifture and cold of the foreft and lake, to protect them againt the numerous tribes of infeets to which they were expofed, and to check the profule perfpiration to which they were fubject, at different times and places.

ID LENESS. - When engaged in hunting and war, the favage appears active, enterprifing, and indefatigable. But when thefe favourite occupations are ended, an univerfal inactivity, and indolence, take place. The time of the Indian is fpent in eating, fleeping, and ftting fill. When he applies to any kind of labour, it is with little activity, and with a great averfion. They will fpend whole years in making a pipe, forming a canoe, or building a hut. The labours of agriculture, are wholly afligned to the women: InaAive and flothful, the man cannot be roufed up to any kind of labour and fatigue. His time is of no value to him : Every thing but hunting and war, is efteemed below his dignity and attention. And of all employments, the loweft and moll bafe, in his view, is digging, toiling, and labouting in the earth. - The moft indolent, flothful, and contemptible, in civilized nations, have the fame idea of honour and indultry ; that labour, efpecial1y agriculture, is beneath their dignity and honour.

$$
\text { U DiRT:NESS. }
$$


DirTiness.-Cleanlinefs feems to be infeparably connected with induftry, and fome degree of refine. ment. Deftitute of both, the favages of Northamerica were funk into the loweft eftate of filth and dirtinels. Nothing can excced the naflinefs that appears in thcir food, in their cabins, and in their garments. The veffels in which they cook and eat their victuals, are never wafhed. The dirt and greale in their buts, are never removed or fwept away. Their garments are never changed or wafhed, until they wear to rags, and wafte away. No idea of cleanlinefs feems to have entcred into their minds. This feems to be one of the cuftoms, common to all favages: Inactive and lazy, they are all extremely filthy and dirty.

GAMING.-Gaming is an amufement, to which indolence and want of employment naturally lead. $\Lambda$ bove the occupations of labour, and without a tafe for ufeful employments, many in civilizcd life feek a relief in gaming, for the pains of indolence; and for a method, to move and agitate a languid band. Moved by the fame caule and motive, the favage alfo falls to gaming, as the molt favourite amufement: Indolent and lifelefs in all the exertions of labour, he becomes deeply engarged, impetuous, and noify in play. Every thing he poffefles, is ftaked at thefe diverfions; and he loofes his peace, his fentes, and all that he is worth: But thefe anufements do not iffue in contention and quarrels: Though carricd on with a frantic cagernets, they are generally managed, and terminate in good humour and peace.

Songs.-Averfe to all abfrufe meditations, the Indians are much delighted with fongs. To an European ear, their fongs do not afford much cntertainment; nor can firch difcern harmony, melody, or any variety in their tunes. Fowever this may be, the ravages are always delighted with mulic. "their fongs are of a grave and lewous turn. They 
never relate to the concerns of gallantry and love, but to their moft ferious employnents. They have fongs for war, fongs for victory, and fongs for death? Each of them is defigned to excite and call forth the fentiments, feelings, and paffions, that fuch occalfions require; and they have a great influence on their feelings, and actions. Amidnt the fevereft fufferings of death, this is the refort of the lavage; and when burning at the ftake, the laft confolation, is to fing. the fong of triumph and death.

DANCING.-Dancing has been one of the favourite amufements of all nations. In civilized focieties this amufement is defigned to promote a refinement of manners; and ferves to excite the fenfibility, and delicacy, which attaches and refines the fexes. Dancing is alfo the favourite employment of the favage, in every part of the globe. It calls forth his active powers, which, when unemployed, languith and decay for want of exercife. And in no em: ployment, does he become more animated, vigorous, and eager.-Inftead of being an amufement, an alfair: of gallantry, love, or refinement, dancing, among the favages, is a ceremony of great importance and ferioufnefs. With this ceremony war is declared, an ambaffador is received, and peace is concluded. It is by a dance, that every important tranfaction in public or private life, is celebrated.-Their dances are generally carried on by the men, and it is but feldom that the women are permitted to join in them. All the fteps, figures, and motions of the dance, are expreffive; and fignificant of the bufinefs or tranfaction, it is defigned to denote. If war is to be proclaimed, the dance is expreffive of the refent. ment and rage they bear to their enemies, and of the holtile manner, in which they mean to treat them. If a party are going forth againt their cnemies, the dance of war is to be performed. In this, the tranfsetions of the whole campaign are to be expreffed. 
The warriors are reprefented as departing from their country, entering that of the cnemy, furprifing and conquering their foes, feizing prifoners, fcalping the dead, and returning in triumph to the applaufe of their country. The performers appear to be ágitat. ed with all the natural paffions and feelings, that take place in any of thefe fcenes. The caution, the fecrecy, the fiercenefs and cruelty of the wamiors, is reprefented in a natural and animated manner. The whole is defigned to excite thofe paffions and feelings in the warrior, which it is defigned to reprefent. And fo quick, exact, and dreadful, is the rep. refentation, that the uninformed fpectator is Aruck with horror, and looks to fee the ground covered with mangled limbs, and laughtered bodies. If peace is made, this is alfo celcbrated by a dance. The ambaffadors and the warriors moke in the fame pipe, and join together in the fame dance. The dance is adapted to fignify that the hatchet is buried, that the blood is all waned aypay, and that the ghofts of the flain are appealed; and at reft; and that both nations are now to live, in all the friend" Ship and familiarity of brotherhood. Thus inftead of being barely an amufement and diverfion, dancing among the Indians, is a very, important and lerious ceremony ; defigned to reprefent fome important tranfaction, and to infpire thofe feelings and patlions, which it fhould naturally produce. - Is it not remarkable, that ainong the favages in the firft ftage of fociety, dancing thould be adapted to pub. lic and national purpoles; that all the fleps, figures, and motions of it, hould be arts of imitation; and that among civilized nations, all the fteps and motions thould be without defign, infignificant, and without any meaning at all?

BEAKD.- The cuntoms and methods of different nations, have been various and different, refpecting their beards. Some have carefully preferved them 
as the tokens of manbood, gravity, and majeny. Others have curled, twifted, and braided them, to give the appearance of elegance and beauty : Others have entirely cut them off, as an ufelefs incumbrance; and to acquire greater foftnels, mildnefs, and amiablenefs of appearance. Thefe different cufloms and fafhions, do not appear to be derived from any permanent caufe, or inftinct founded in nature; but to be matters of fancy, fuperfition, convenience, or vanity.-In this refpect the Indians had a cuftom, different from thole of other nations. It is their univerfal and conftant practice, to pluck them out by the roots; and to deftroy, as far as poffible, the appearance of any beard at all. Every man has an inftrument made for this purpole: It confifts of a wire, twifted round a fick, in fuch a manner as to draw the hair out of the fleth, and extract the root. The Indian carries fuch an inftrument with him : And it makes a regular and conftant part, of what he efteems his drefs, to extract and deftroy his beard. So fond are they of this cuftom, that whenever the Indian can obtain a looking. glafs, his firft bufinels is to examine his face, and with this kind of tweezer, pluck out all the hairs he can difcover. They generally recommend this cuftom to their captives, as what would increafe their beauty, and deftroy their hairy appearance, which the favage greatly dillikes.

Some philofophers have fuppoled, that the beardlefs countenance of the Indian, is derived not from cuftom, but from nature : That the Indian is without any beard, or hair on any part of his body, ex-. cept the eyebrows and head : That this arifes from a defect in the powers and vigour of nature ; and is an evidence of weaknels, impotency, and want of manhood.* The fact, and the conclufion, are both miftakes.

* Buffon, Kaims, Robertion, \&ce 


\section{$15^{8}$ TIS NATURAL AND CIVIL}

miftakes. Nature is the fame in the Indian, as it is in the European: And on whatever part of the body it has affigned hair to the one, it lias given it to the other. I an affured of this from thole who have flain, fripped, and buried their warriors : I have the fame information from thofe, who have been their captives; and who have feen all the nembers of an Indian family, dreffed and undreffed, and in all fituations. The fame is afferted by thofe, who have lived among the civilized tribes, and been called to perform offices of humanity, to the Indians of each fex. The beardlefs countenance of the Indian then, is not to be ranked among the curious and extraordinary phenomena of nature, but is to be placed among the cuftoms peculiar to the Indian tribes.

DRUNKENNESS.-Drunkennels is one of tholé vices, which prevail among a rude and uncultivated people. The favages of Northamerica, are universally addicted to it. Before they were acquainted with the Europeans, they had difcovered a compofifion, or liquor, of an inebriating nature, made out of maize or Indian corn. But the difficulty of procuring a large quantity of this liquor, prevented any general intemperance, or excefs. No fooner had they tafled of the fpirituous liquors brought by the Iuropeans, than they contracted a new appetite, which they were wholly unable to govern. The Europeans found it the molt lucrative branch of the Indian trade, to gratify this inclination. With an avidity of defire altogether uncontroulable, the Indians'fell into the fnare. The firt object of inquiry with them, was; whether the trader had brought any brandy or rum; and no confiderations could refrrain thetn in the ufe of it. The old and the young, the fachem, the warrior, and the women, whenever they can obtain ftrong liquors, indulge chemfelves without mokeration, and without decen. 
cy, until univerfal drunkennels takes place. All the tribes whether placed in a temperate, or in a fevere climate, appear to be under the dominion, and unable to govern this appetite.

An effect fo univerfal and fimilar, muft have as general and univerfal a caufe. The caufe will be found to have a deep and a ftrong foundation, in their manner, cuftom, and habit of living. Their conftant method of living, was on raw or boiled meat, and frefh water. This did not fatisfy the de-. fires of nature; and naturally produced an appetite for every thing, which was aftringent, ftimulating, and inflammatory. When they met with ardene fpirit, they found that, which is the moft highly gratifying to fuch an appetite. The hardfhips and fufferings to which the Indian was expofed, their want of comfortable refrefhments and fupport, and the extremes of heat, cold, and moifture, to which they were fubject, were conftantly adding new force, to an appetite already exceflive. Few of the white people, who have been reduced to fuch a fituation for a few months, hare been able to preferve their temperance. The Indian proved $w$ holly inadequate to the trial. Unaccuftomed to lay any reftraint on his appetites and paffions; and unable to bear but a fmall quantity of the liquor, to which he had been unufed, he is overcome upon the firft trial. His appetite, the more intlamed by irregular enjoyment, becomes more keen and raging, until extreme cxcels puts it out of his power to indulge himfelf any longer. Nothing but a total change of the whole method of his living, will enable him to preferve that temperance and regularity, which to a perfon furrounded with all the comforts of life, is an eafy and a com. mon attainment.

CRUELTX. - There are no paffions in the human mind, which operate with fo much force and fierce. Defs, as thofe of anger and revenge. The cuftoms and 
and maxims of polifhed focieties, with all the aid of their laws and religion, have not as yet been able to give a due regulation or reftraint to thefe paffions. In many cales, an offended individual cannot be made to believe, but what it is right and beft for him, to be the judge and the avenger of his own injuries; and that it is the mark of meannels, to leave it to the laws of fociety, to make a proper retaliation to the wrongs he has received. Higher attainments muft yet be made in the ftate of fociety, before an adequate reftraint and regulation will be found for thefe paffions. - In the brealt of a favage, they rage without any controul : Inftead of being taught any reftraint, the young favage is taught in early life, to gratify and indulge them. The whole force of education, example, cuftom, habit, and manner of living, operate with a decifive influence, to give them new force and vigour. By the government of the tribe, the revenge of injuries is left in the hands of every individual ; and to be patient and moderate, is the higheff'mark of meanners and want of rpirit. To give further force to the fpirit of vengeance, all the maxims and cuftoms of war, have placed the point of honour, in rendering the fpirit of revenge, implaca ble, unabating, and fuch as never can be fatisfied, fubdued, or loft. Aided by all thefe motives and confiderations, anger and revenge, become fierce, brutal, horid, bloody, and implacable paltions, in the breaft of the favage: More like the deftructive rage of a beaft of prey, than like a paftion in the heart of a human being. - The effect, is a barbarous and unrelenting cruelty : Far from pitying, fparing, or forgiving, the favage aims at the ruin, deftruction, and utter extermination of his enemies. Hence the method of carrying on his war, was to defroy men, wornen, and children: To plínder and burn their tuwns, and villages: To torture and torment their prifoners: And to freep off whole tribes, with an 
univerfal and undiftinguifhed carnage. This feems to have been the wifh and aim of every tribe; when: they engaged in war. A barbarous, unrelenting cruelty, diftinguifhed and marked all their fleps.

The cruelty of the Indian feems to have arifent from the paffions of anger and revenge. It is no to be denied but that there are other paffions, which have carried civilized nations, to the fane dreadful extremes in cruelty. - Avarice led the Spaniards to perpetrate more enormous crimes and cruelty upon the Indians, than the Indians were ever capable of returning. The fcene of promifcuous calamity, defruction; murder, and butchery; which the Spaniards carried through all parts of Southamerica, in the number; defign, degree, duration; variety, and enormity of its cruelties, far exceeded any thing that was ever perpetrated by the Indians. If we are to believe the declarations of a celebrated modern ftate[man,* the avarice of a company of merchants, has murdered millions and millions of mankind, by. ftarving them to death in Bengal. - The fpirit of fuperfition and bigotry, is equally cruel and unrelenting. The murders of the inquifition fubfited for centuries: They were fanctioned by law, and are not yet done away: Imprifonment, confilcation, and death in its nolt awful forms, were the punifhments which bigots, whenever they had power, never failed to inflict with great pleafure, upon thofe who were wife and virtuous enough to oppofe them. The maffacre on St. Bartholomew's day, in 1572 , was orie of the molt barbarous and horrid of all human tranfactions. In the midf of the noft polite city in.Europe, the king, princes, nobility, and priells; turned monfters, affaffins, and butchers ; and murdered thirty thoufand of their fellow uren, on ace count of thetrir religion. Their rage was attended W with

- Mro Barkti. 
whth circumftances of inhuman criclty and barbarity, far exceeding the fierce and bloody paffions of the favages of Ainerica.-Oar own'countrymen ought not to forget, that revente has alfo tranlported them into a conduct, equally inhuman' and 'barbaroús as thit of the Indians: At the conclufion of the Indian war, in 1676 , the government tried feveral of their captives, by the Englifh laws : Some were condemned, and exéculed upon tho gallots'; in ath' ers were font to confume their days, in the flavery of the Weltindian iflands : A punifhrient; to then more ferere thandeath.

In the cruelty and barbarity of the Indiars, man appears in a fituation but little removed from the brutal ferocity of the beaft of prey. But when ava. rice, bigotry, and revenge, produce the fame infernal fpirit among civilized nations, cruelty appears"with a more diabolical- afpeet; not like the rage of: witd beafts, but like'the fury and vengeance of a combination of apoftate fpirits. - The progrefs of knowledge, humanity; and refinement, will afford the only effectual remedy for this evil.

Such were the regulations, cuftoms, and manners of the Indians, the original men of America. They have been viewed by philofophers, in the moft oppofite and contrany lights. Some have fuppofed that the Indians were in the infancy of exiftence, that the whole continent of America was but lately raifed out of the fea, and that her inhabitants were in a fate of degradation, unworthy to be compared with the men of the more ancient and improved: hemifphese.* On the contraty, others have contended that in the rudeft and moft fimple flate; man. attains an independence, a dignity, and a nobleners of nind, which is never found, but is always loft; amidf the refinements of polifhed locieties: Thas 
the highelt dignity and noblenefs of man, is derived folely from nature, and is always debafed and corrupted by polio, refinement, and the arts.*-To view this fubjed in its proper light, it will be nec-: cliary to compare the favage with the civilized ftate, and tol wask the various Ldvaniages, and Difadvanhages of it.

The Savage State, favourable to the IEALTI, ACTIYITYA AN VIGOUR OF, THE BODY. - Among the sdoantages that were connected with the favage fate, it may jultiy be efteemed one, and a matter of much importance, that it was favourable to the vigour, activity, and health of the body. It i $\hat{p}_{\mathrm{s}}$ by exertion and exercile, that the body $\}$ acquires its moft improved thate of activity, firmnefs, vigour, and health. Accufomed to range the forefts in queft of game, the Indian acquired an habit and activity. in travelling, that exceeded that of any other people. In the expedition, fwiftnefs, and perféverance of his courfe, he much exceeds the European. - No people bear hardhip, fuffering, and fatigue fo welli: The cxtremities of heat and cold, of hunger and thint, of bad weather, and of bad accommodations, are per: fectly familiar to the Indian: Ind he bears them with a much lefs effect upon his conflitution, than the men wlio have been ufed to better-accommodations. - Unaccuftomed to the fteacy and régular employments of agriculture, lis body does not acquire the nrength that the Luropeans lave: And when the exertion, is an exertion of frength, and fteady labour, the white man is found to be the frongeft. Thofe only of the Indians, who have been educterl and trained up to fteady and hard work, are equal to the white men in bodily ftrength. In running the race, andin bearing hardfhip, the indian expeeds: but in ftrength of body, and bearing hard and fteady labour, he is generatly unequal to the Earopean

$$
\text { Rou Eeau. }
$$


In refpect to health, the favage fite feems fully equal to the civilized: Ufed to all theivariations of the weather and cliniate, he fuffered but little from: fuch changes: The difeafes to which the Indians: were fubject, were chiefly thofe wlich arofe from exercife, hardhips, and fatigues. Fevers, the afthma; and paralytic diforders, made the capital articles in the hiftory of the Indian difeafes?' But that numerous and fearfül train of / maladies, which arife from Juxury, foth; intemperance, and want of exercife, were unnamed, and unknown among the Indian tribes. - In their villages there feemed to be agreater number of decayed and aged perforis, than are generally to be found among an equal number of white people. But as they had not the art of numbers and computation, no exad accounts could be procured of their age. - This article refts therefore rath-: er upon: appearance, and indication derived from decrepit and thrivelled bodies, than from any proper and autheritic accounts of the years and longevity, to which they attain. All appearances however feem to indicate, that activity, vigour, health, and age, were to be found to great advantage in the fav. age ftate.

Favourable to Firmess and Fortitude or MrND.-The fituation and employment that promoted the vigour and health of the body, tended to produce independence, firmners, and fortitude in the mind. Inured to fuffering, hardthip, and danger; the mind of the favage was formed to an habitual firmnefs, and courage. His mind became compofed and collected in cyitical and dangerous fituations: And he fuffered but little from apprehenfrons of fear. - The fpirit of freedom and independence, was cultivated and confirmed by every circumftance attending his education, employment, and reppatation: Neither correctedinor checked in his early yeàrs, retarded or ftopped in any purfuit, he knew 
of no controul, or reftraint. Malter of his own actions, and never wifhing to moderate his paffions, the fpirit of freedom and independence took the entire poifleftion of his foul. Moved by, and perpetually confcious of this independent fpirit, he acted in circumftances of diftrefs, and danger, with amazing force and magnanimity of mind.-But that which the favage efteemed his greateft glory and higheft dignity, was his fortitude and bravery. To bear hardfhip, to endure fuffering, to be unmoved in the midft of torment, and to rife fuperiour to any thing that could be laid upon him; this, was the higheft honour, and the nobleft attainment of the warrior. And in this, it is not - to be denied, that the human mind attained in the favage ftate, a fortitude and a magnanimity that it does not attain, amidft the refinements, cuftoms, and maxims of polifhed nations. Amazed at the firmners and fortitude, which the favage difplays in the molt dreadful of all fituations, feveral philofophers have aimed to difcover fome ap. athy, fome natural defect, or want of fenfibility in his frame, which qualified him to bear pain with lefs feeling, and with more fortitude; than other men. There is no fuch defect in his conftitution. His magnanimity arifes from a fenfe and principle of honour. This is the firft principle he is taught; the fole object of his education, profeffion, and purfuit. Amidnt the rudenefs and hardihood of the favage ftate, this principle acts with more force and vigour upon the human mind, than -it ever acquires amidet the refinements and foftnefs of a more polifhed ftate of fociety. Refinement, and the arts, foften and relax the mind; philofophy dibilitates the body, while it aims to correct all rudenefs and ex. -cefs, in the mind, and to give it a juft habit and tone of thinking and acting: But in the rudenefs of the favage ftate, every thing concurs to give an unaltered firmnefs to the body, and to the mind; the prin. 
ciple of honour has nothing to oppofe or relax it : And it will be in the molt hardy body and mind, that nature and honour will at with the greatent force: and vigour. The principles of religion only, have ever produced a fimilar phenomenon. The heroic, fpirit of the martyr, undaunted and triumphant in, the torture, and in the flame, has alone exceeded or equalied the fortitude and magnanimity of the man of naiture.

Favograber to Potitical Táents, and? YinTUE. - The davage ftate was allo friendly to forme of the political talents and virtues. The love. of bis courdry, derived fiom nature, cherifhed by ieducation, ambition; precept, and example, became a very jowerfial principle in the brealt of a favage. His affections were confined to the limits of his own tribe, and his views never extended any further. His glory terminated in the fervices he could render to it: And the greatel of all attainments was to expand the national fame, reputation, and conquefts. To this he became attuched by birth, education, and intereft; by ambition, honotr, and a thirft for glo2y. Every paffion that glowed in the breaft of the iavage, ferved to incrcale and add frength to the love of his couniry. No motives of ambition, gain, reverige, or policy; ever lead him to betray its intereffs or councils, to defert to the enemy, or to prove a trator to the country and tribe, that gave hirn birtb. This principle conneded together the members of the fame tribe: It feems to have taken the deepeft root, to have acted with the greatef force, and to have been the leaft corrupted, in the lavage Itate.

When the interefts of their cointry were to be confruber, much pradence and wifom were difplayed in theil councils. The chiefs and elders confultfd with grieat deliberation, ferioufnels, and calmnefs ; and rifhout any appearance of provacaton; refent- 
ment, or inpatience at contradiction and oppofition. Every propofal was confidered; the probable effects and confequences, advantages and difadvantages, were examined and weighed. No heat, anger, ill nature; or reflections upon nne another, but perfec calmnefs prevailed: And that conclufion was embraced; wlick appeared to be moft beneficial to the sribe. Thofe of the Europeans who have attended thefe coincils of the faviages, have compared them to the accounts hiftorians have given us, of the proceédings of the fenates in the ancient republics. * They bor'e the appearance of folemnity; gravity, and cieliberation. In thefe councils, integrity and pablis virtue was always preferved. The objects they had to determine, were sot of a trivial or infignificant nature: They were thele, which involve all that is the $m p$ h dear, yaluable, and important to man, in any. Atage of fociety: "The prefdryation and protection of their property the fafety and the lives of their wives; ehildren; and fathers; the exiftence, the independence, and the freedom of their country. The councils of civilized nations may be employed. upon objects of a much greater extent; but they never can contemplate objects : more importance, of greater value, of of a higher nature. In attending. to them the mind of the favage became compofed, fedate, grave, and ferious... He had no, private intereft to corrupt him; no broken fortune to be repaired; nothing to be expected from: the misfortunes of his countly; from lucrative jobs; pofts of , hoinout and profit; from the management of the public wealth; or from the weaknefs, prejudice, and tavourite paffions of a prince. No emoluments or advantages could accrue to him, but thofe of the public gond. In fuch a fituation, corruption would not enter into the councils of the favages. There was nothing to be gained by intrigue, diffimulation, or knavery. * Charlevoix iii, 26, Smith's Hif, Newyork, p. 53. Phil. Edit, 
knavery. All the advantages that could arife to ifto dividuals, muft arife-fron the general good of the tribe. And where there was nothing to be gained by corruption, there was nothing left for their counfellors, but to difplay their greateft wifdom, integrity, and public vircue.

The nature of their government and councils was alfo favourable to eloquence, and the art of public speaking. This feems to have been the only art, in which the Indian rofe, to any eminence. Unable to remember an irregular unconnected difcourfe; the Indian was extremely fond of regularity and method. When he fpoke, his - fpeech wasi thort and laconic and the meaning was conveyed in bold and ftrong metaphors. When they return an anfwer, they repeat the whole that has been faid to them, and reduce it into a ftriet and regular order. . Their words are. but ' few; the language ftrong, and figurative; the figures exprefive, vigorous, and bold; their manner, grave and animating; the torie, determined and decifive; and, the fentinent they mean to convey, fo clearly expreffed, that they are never mifunderftood. An hiftorian who was prefent at feveral of their conferences with the Englinf, gives this account of the appearance and manners of their orators, "Their fpeakers deliver themfelves with furprifing force, and great propriety of gefture. 'The fiercenefs of their countenances, the flowirg blanket, elevated tone, naked arm, and erect ftature, with a half circle of auditors feated on the ground, and in the open air, can: not but imprefs upon the mind, a lively idea of the ancient orators ' of Greece and Kome."*- Sorne of their fpeeches in manlinefs of fentiment, in the force of exprefion, and in the elegance of the arrangement; have been fully equal to the productions of the Grecian, Roman, or Britifti eloquence. And in' no cafe does.

$$
\text { * Smitn's Hiftrof Newyork, p. 53. }
$$


does language acquire fuch force and vigour, as when it is the dictate of the paffions and feelings of nature, in her rude and uncultivated fate.

It was by the combination of thefe virtues and abilities, that the favage role to public isonours, ems ployment, and diftinction. The braveft and the wifelt became the leader, and the fachem. No other arts could fecure the public efteem and favour, but fuperiour abilities and exploits. The ancients generally numbered good fortune, among the moft neceffary qualifications of their heroes. The Indians adapted this idea in its full force, and extent. Without diftinguifhed bravery and fuccefs, the private man was never promoted at all : If he proved an unfortunate and unfuccefsful leader, he foon loft all his influence and reputation.

In thefe maxims and cuftoms of the favage ftate; there were conftant and powerful motives, to the exertion of all their political talents and virtues : And there was much lefs intrigue and corruption in thofe public proceedings, which related to their orvn tribe, than there generally is in the tranfactions of civilized focieties.

Fivourable to the Exercise of some Vira TUES. - Several of the vices that prevail among polilhed nations, were feldom to be found among the Indians; and there were forne virtues, to the exercife of which, the favage ftate was not unfriendly: The horpitality which the ancients celebrated fo much, was of great importance and ufe in the early ftages of fociety. When the ftranger and traveller could find no accominodation or protedion, but in the kinduefs of thofe on whom he called for relief, hofpitulity became a virtue of the higheft ufe and rxcellency: The bufinefs and convenience of life, could not have bein eafly carried on wichous it. As locicty became improved, the ftranger found in the protedion of laws, and in the ufe of morey, that -

$$
\text { xo relief, }
$$


selief, which he before derived frum the hofpitality of the age. In polithed nations the necelfity, and the exiltence of this virtue, have in a great meafure ceafed. Among the favages it prevailed to an high degrce, and arted with its full force. The Euro. peans every where found the moft friendly and cordial reception, when they firft came among the lavages; and from their hofpitality, they derived all the afriflance the lavages could afford them. It was. not until dilputes and differences had taken place, that the Indians became unfriendly. Even now, an unarmed defencelels franger, that repairs to them for relief and protection, is fure to find fafety and affifance in their hofpitality. - The friendfhip of the Indian, is always a very frong and vigorous affecion. His pafions unfubdued, undifciplined, and ungoverned, always at with gireat forec and vigour: Whatever be the object of them, the paffion itfelf is always impetuous and frong. No bounds are fot to his refentment and revenge, when injtured; and no length of time, will obliterate the memory of a favour. The lame impeisolity and perfeverance, with which he purfues his encmy, is employed to affit and preferve his friend. In this relpeet, the Indian attachments have fully equalled any thing that is to be found, in the hiftory of inar. Sevcral of their beft concerted expeditions have failed, through the anxiety of an individual to preferve a friend from the common vengeance and deftruction.

Trained up to the moft refined cunning and diffimulation in war, the Indian carries nothing of this into the affairs of commerce; but is fair, open, and honeft in his trade. He was accuftomed to no falfehood or deception, in the management of his barter. And he was aftonifhed at the deceit, knavery, and fraud of the European traders.-He had no bolts or locks to gutard againft thealing, nor did: 
he ever conceive his property was in any danger of being ftolen, by any of his tribe. All that train of infamous and unmanly vices, which arife from avarice, were almolt unknown to the favage ftate.-Lying and falfehood were viewed with horror, and de. tefation. When they found thefe vices common among fome of the Europeans, the Indians viewed them as a corrupt and odious race; in whofe truth, juftice, and declarations, no faith could be placed. They had no name for adultery, or rape. Quarreling, contention, and difcord, with their numcrous ill effeets, were but little known among the members of the fame tribe.

Their morality, confined to a few objects, admitted of fewer vices than the civilized ftate. Where no wants are known but thofe of nature, and the way to fupply thofe wants is the fame, and open to all ; the individuals of the fame fociety, will live in a friendly and cordial manner together; without many grounds of ftrife, and without much temptation to iujure each other. In the language of the Indians, this is denominated a ftate of brotherhood: In this ftate, the moral fenfe will join its influerce with the focial affections, to prevent injuries, evils, and vices; and to reftrain the members of the tribe, from violating the rules of morality. As fuch a nate does not admit of many of the virtues of civilized nations, it is alfo in a great meafure free, from many of their molt dangerous vices.

In fuch refpects, the favage fate fecms to have had advantages peculiar to itfelf; and to have pro. duced effects, which are not to be expected among civilized nations. But before we decide on its operation and tendency, it will be neceflury to exam. ine the difadvantages, to which it is fubject; with their influence, and effect on fociety.

The Savage State Unfavourable to ali. INTELLECTUAL IMPROVEAENTS. As one difar. 
vantage of the favage fate, it lias confantly proved unfavourable to all intellectual improvements and exertions. Occupied folely with hunting and war, the favage had no idea or wifh for any intellectual attainment, which was not immediately connecled with his favourite profeffions. Neither his reafon, nor his invention, appear to have been much exercifed upon any object, not fuggefted by his necefliries.-Taking the game, and fubduing his enemy, did not depend on the knowledge of letters. The tranlactions of his anceftors, were not of much importance to him: He had no code of laws, no evidences of property, or any public tranfactions to be recorded. With thefe arts, of fo much importance to civilized nations, but of little confequence to the Indians, they were wholly unacquainted ; and had not made any advance towards the difcovery of letters. The only thing which they appeared anxious to record, was the exploits of their warriors. When a party of thefe had met with uncommon fuccels, it was often the cafe that they made fome very rough figures or inferiptions upon the trecs, to reprefent the direction of thei: march, the number of enemies which they had Rain, and taken captive.* Thefe kind of infcriptions were fometimes mide upon the rocks. A number of fuch figures are yet to be feen upon the rocks at the mouth of Weft river in this ftate. They fecm to allude to the affairs of war, but their rudenefs and awkwardinefs denotes that the formers of them were at a great remove from the knowledge of any alphabet. - The art of numbering and computation, is an elementary and efrential art in every nation where bufnels is tranfacted, or any confiderable intercourfe and commerce is carried on. But the favage had nothing to number, that was of inuch importance to him: He had no treafures to count ;

* Sir W. Johnfon's account : Phil, Tranf, Vol, LXI̦I! page 143: 
count; no property, the value of which, was to be computed; nor any variety of objects, the number and value of which, muft be expreffed by figures. Arithmetic would therefore have been an ufelefs art to the Indian ; and he had not made any attempt to attain it. They could count as far as ten or twenty; all beyond this, was compared to the number of the trees, or the hair un their heads. - The on!y objects, on which the Indian had employed his reafon, were thofe of external fenfe; fuch as are material or corperal, the idea of which is received by the fenfes. They had no name for any of the fciences, or for abftract and univerfal ideas. Time, fpace, duration, fubllance, and all thofe terms, which are ufed to reprefent abftract and univerfal ideas, appear to have been unknown; and probably never were the objects of their inquiry, contemplation, or thought.

The ideas of religion, were extremely weak and obfcure in the favage. Our Maker has not left us to a courfe of metaphyfical reafoning upon the connexion between caufe and effect, to come to the knowledge of his exiftence. Long before men become capable of fuch exercifes of the reafoning powers, they believe in the exiftence of a Deity. A fenfe of his being, feems to be infcribed upon the human mind. And probably no tribe has ever been found, that had not the idea of fome fuperiour pow erful being. Whether this was the object of fear, or of love, or however it was reprefented, the idea of a luperiour being feems to have been common and general among all nations. It takes place in the mind, bcfore we are capable of reafoning about caufe and effect: And it feerns to be derived from a revelation, which the Deity hath made of himfelf to man. In the conftitution of the human mind, in its feelings, paffions and motions, a fenfe of the Deity feems to be interwoyen, inftamped, and infcribed. 
And this revelation becomrs more clear, plain, and intelligible, according to the manner and degree in which it is improved. Among the Indians, it appeared in its weakeft and molt obfcure flate. They denominated the Deity, the Great Spirit, the Great Mon above; and feemed to have fome general, but very obfcuic ideas of his government, providence, univerfal power, and dominion.

The immorality of the foul, was every where admitted among the Indian tribes. The fentiment itfelf refults from our fears, hopes, and feelings. Man is fcarcely ever degraded and funk fo low, but that he hopes and believes that death will not prove the extinction of his being. This fentiment prevailed in every part of America. The Indians fo firmily belicved it, that it was their general cuftom to bury with the dead, their bows, their arrows, their fpears, and forne venifon, that they might not be wholly unprepared to begin their courfe with adrantage, in another ftate. There might be a few exceptions, but the general fentiment was nearly the fame in every part of the continent.

But both thefe fentiments, the exiftence of a God, and the immortality of the foul, were nothing more in the favage, than the dictate and voice of nature. They were not the objects of his inquiry,-difcourfe, reafoning, or contemplation. The lndians had made no improvements, no cultivation of the gifts of nature and providence; and they had very little inlluence on any part of his conduct. They had not produced any domeftic, or public devotion; any form, rite, or mode of worfhip; or any fyftem of manners and cuftoms, favourable to national virtue and religion. Without a prief, without a temple, facrifice, or altar, the Indian was funk under the thickeft gloom of ignorance, fuperftition, and ftupidity.

His reafon, never employed on any intellectual attainment or exertion, he remained in a ftate of nature; 
nature; wholly unacquainted with every thing derived from the exercile, improvement, and cultivation of the powers of the mind. Neither his reafon, or his defires, ever moved or tended towards any fuch improvements : And fo long as hunting fhould have continued to be the mode of his fubfiftence, fo long it is probable, he would have remained at a difance from every intellectual attainment.

ADMITS OF BUT FEW VIRTUES.-It was another difadvantage of the favage ftate, that it did not admit of but fer virtues. The moral fenfe, or confience, makes past of our natural confitution ; and is as effential to man, as his appetites and paffions, as his countenance and form. When this is noe corrupted or perverted, its dictates are clear and right, and do not tend to millead us : And its dictates are never more clear and certain, than when they are the genuine and fimple voice of nature. There were fewer temptations and there were fewer vices in the favage ftate, to corrupt and pervert the moral fenfe, than there are in a polifhed ftate of fociety : But there were alfo fewer motives, occafions, and opportunities for virtue. Reverence and re. fpeet to the Deity, had little place or effeet on the uncultivated mind of the favage. There was nothing in his fituation to produce thofe offices of kindnefs, and tendernefs, which foften the heart, and fweeten the intercourfe of life, in the civilized ftate. The fullen pride of independence, was the ftrongeft paffion in the heart of the Indian; and it left but little room, for tender and generous affections to others. Depending folely upon himfelf, the hear: of the favage contracts an infenfibility, an hardnels, a roushnefs, very unfavourable to focial connexions. Expeeting no offices of kindnefs from others, he was. very little employed in relieving the diftreffes, fupplying the wants, or gratifying the defres of others. In a heart thus contracted, but few virtues will re. Ede. 
176 THE NATURAL AND CIVIL

fide. The natural affections will remain, and may become ftrong and vigorous: But the divine, focial, and human virtues, find an unfriendly foil ; become few in their number, and weak in their operation.

No Attainments in the Arts.-Thofe arts, which are the moft neceffary and ufeful to men in the civil ftate, were almoft wholly unknown amorig the favages. - To provide a covering to defend the body againft heat, cold, and moifure, is one of the firf arts that man mult have attended to. The Indian had gone no further in this primary and effential art, than to apply the fkins and furs of animals to this purpole. The art of fpinning, knitting, and weaving, were wholly unknown to the northern Indians. They had no other materials to covet and clothe their bodies, than what were derived from hunting.-Architecture of fome kind and form, mult unavoidably engage the attention of men, in every climate and country. The attainments of the Indians in this art, were the loweft that can be conceived. Their buildings were nothing more than a few temporary and wretched huts, put together without oider, ftrength, or convenience. Some crotched fakes were thruft into the ground: Thefe were connected by poles, laid from the one to the other; and the whole was covered with the bark, limbs, and leaves of the trees. An aperture was left at the top, for the conveyance of fmoke ; and the fire was kindled in the middle. This was called a cabin or wigwam, and was without windows, doors, or any divifion of apartments. This was the higheft elegance and convenience, the houfe of the Indian liad attained.

The progrefs of the arts, depends rery much on the infruments and tools, with which the artificers are furnifhed. Moft of thefe among civilized nations are derived from the application, and ufe of 
the metals; particularly that of iron. From this metal is formed almoft every inftrument, that is employed in peace, or in war. Civilized nations have availed themfelves of the difcovery and ufe of this metal, in every kind of art that they purfue. The Indian was in no capacity to arrive to fuch an improvement. Copper, filver, and gold, have been found in their perfect ftate, in the rocks, mountains, and rivers; and were the metals, which were firft known and ufed. But nature never completes the formation of iron. It mult pafs through two or three tedious operations by fire, before it appears in its perfect and ufeful form. With the former metals, the Indians in fome parts of America, were well acquainted : But of the nature and ufe of iron, all of them were wholly ignorant. - Deftitute of this capital advantage, all their tools and inftruments to an European, would have been wholly ufelefs. Their axe was made of a tharpened ftone. Their knife was formed out of a Thell, or bone. Every other inftrument was equally impotent, and ill contrived. - The arms they had contrived for defence, or attack, were equally feeble and awkward : A club made of hard wood, a ftake hardened in the fire, a lance armed with a flint or a bone, a bow and an arrow, conftituted the whole artillery of an Indian war. Of domeftic utenfils and houfehold furniture, they had nothing that deferved the name. A bed, a chair, a table, a pot, a kettle, or an oven, were wholly unknown. Their bread was baked on the coals. Their meat was broiled in the fame manner. Their greatef art in cookery, was their method of boiling their food. A piece of wood, or a ftone, with extreme labour, was formed into a hollow, and filled witl water; and this water was made to boil, by throwing into it flones heated red hot.

The greateft performance of the Indian genius, was the confriction of hic canoe. With infinite I

labour, 
labour, they fometimes hollowed out a tree, and gave it a form adapted to the purpofe of navigation. In a canoe thus formed, four or five Indians would pafs a river, a large lake, or a dangerous rapid, with. much fafety, and dexterity. Another kind of canoe, was formed out of the bark of the elm, or birch. This was the work of but a few days, and was cxtremely light and convenient. It was of fufficient dimenfons, to carry four or five Indians; and fo fight, that one of them could eafily carry it on his back. The dexterity of his management, the fwiftnefs of his voyage, and the fafety with which the Indians pals the fallis, rapids, and waves in this lkind of boat, has appeared Turprifing to thofe perfons, who. srere beft acquainted with the arts of navigation. Ard it feems to have been the higheft attainment, to. which the genius or invention of the Indian, had ever. arifen.

In the application and uie of particular vegetable, animal, and mineral fubftances, the Indians feem to hate had fome information, which ought to have been more attended to; and better afcertained. They eertainly knew of fome fubftances which gave the moit vivid and permanent colours; and of others which contained the molt fubtle, active, and powerful poifons. In feveral cafes of poifons, wounds, and fume, other diforders, the Indians had the knowledge of very valuable medicines: And they derived fipport, refrefoment, and medicine, from feveral plants and regetables, in which the englifi had not difcovered any fuch virtzes or qualities. The knowledge of firch facts, was the refult of fuch obfervations, as experience natarally produced. But as the Indian never attrmpted to impreve any information which he had, and knew of no method to preferve is but tradition, he made fmall advances in this kind of J howledge; and it was rather a matter of fecrecy, "thata of inve!lifation. Nor was there any thing in:

his. 
this fituation, or employment, adapted to call forth the latent powers of his mind, and to produce the spirit of inquiry and improvement.

VerY UNFAVOURABEe to POPUlation. - A diradvantage ftill more unfavourable attended the favage ftate, it tended much to retard population. From the earlieft hiftories of Virginia, it has been com. puted that the number of Indians in that part of the continent, did not amount to more than one for every fquare mile.* I do not find any account, which will lead us to cttimate the number of Indians in Newengland, at a higher rario than this.- In thofe parts of the United States where the farms are well manag. ed, a farm of one hundred acres will well fupport a family of ten perfons. This amounts to fixty four perfons, on one fquare mile. The Indian population then, compared to what has already taken place in thofe parts of the United States, which are well fet tled and cultivated, was in no higher a proportion than one to fixty four. A difference fo unfavrurable to the production of life, denotes fome effential defeet in the favage fate.

Population depends upon a variety of circumitarces, all of which are never found to concur, in favour of any people. In the ftate and fituation of the Indians, there were fewer circumftances fivourable to population, than in any other ftate of ?ociety. - In the conftitution, form, and vigour of his body, nature was bountiful to the Indian. In the dimenfions and fize of his body, in the proportion and perfection of all his limbs, members, and organs, he rather exceed. ed than fell thort of the European. All that have been acquainted with the favages, have been ftruck with this circumitance. In no race of men, has the human body appeared to be better formed, more nicely adjufted, or to be more perfeetly proportioned in all its members and parts. No deficiency there.

: Jefferfon's Notes on Virginia, p. 200. fore 
fore arofe from any impotency, or want of vigour, in any of the powers of nature.

But whatever may be the original powers of nature, they are weakened and impaired without proper food, and nourihment: And it is only, where fuitable and nutritive food is to be obtained in regular and fufficient quantities; that animals will become the moft prolific. In this refpeet, the fituation and ftate of the favage, was greatly unfavourable to increafe and populacion. Deftitute of any certain or regular food and nourifhment, the Indians fuffered feverely this way. At one period, all was gluttony and excefs; at another famine and hunger became extreme and dift refling. The heavielt part of this diftrefs fell upon the women, who were the leaft able to bear it: And at no time did they enjoy that regular and fteady fupply of food, which nature required. In the male, this tended to impair the animal paftion: In the female, it tended not only to weaken it, but to render it greatly dangeroug to indulge it. Its effects were ftill worfe upon the pregnant; and often deftroyed the increafe and fruit of nature, before the birth.

The manner in which the Indians procured their food, was equally unfavourable to population, as the uncertainty and irregularity of it. Deftituce of a fixed fettlement and abode, the favage fpent the hunting feafon in wandering through the forefts in queft of game, and generally carried his family with him. Their women muft climb the mountains, wade through the rivers, force their way in the thickets of the foreft, fleep upon the wet ground in the open air, and carry their children with them; and amidit all thefe fatigues and diftrefles, were often without food for feveral days, and always without comfortable refrethment. Intead of being in any degree prolific, the whice women would have all perifhed in fuch a Gituation. The wonder is, not why population fhould 
have been fo fmall, but how it hould fublift at all, in fuch a fituation. If the conftitution of the favage had not been uncommonly ftrong and vigorous, not only the animal paffion, but all the powers of nature would have ceafed and become extinet, by fuch continued fcenes of fatigue and diftrefs.

The conftancy and perpetuity of their wars, had alfo a fatal influence on population. The irruption of an enemy defolated their cultivated lands, difturb. ed them in their hunting exertions, and deftroyed all the little ftock of provifions they had faved. The women and children had no place of refuge, but to conceal themfelves in the woods, and mountains; where many of them muft perifh for want of food, and all of them mult be in a fuffering and diftreffed condition. In the whole catalogue of human woes, it is not poffible to conceive of any ftate more diftrefling, than that of a pregnant woman, in a fituation fo horrid and awful. Many of them lived, and brought forth the fruit of nature, amidit this complication of miferies. But the prefervation of the mother and the child, approached nearer to the nature of a miracle, than to what is efteemed the effect of the eftablifhed and regular laws of nature, in the civilized ftate. - While their wars had this fatal tendency to prevent the increale, they operated with a force equally fatal, to deftroy and fweep off thofe that were the molt vigorous and active. Revenge, deftruction, the utter extermination of an enemy, was the object aimed at in an Indian war: And while it was carried on, it operated and raged with a fatal and a certain tendency, to effect its defign, aim, and end.

Other caufes might be found, in the cuftoms, manners, and maxims of the favages, which were alfo unfavourable to increafe and multiplication; but it is not neceffary to enumerate every particular, that would apply to this fubject. The circumitances 
which have been mentioned, are fufficient to account for all that has been uncommon, in the defect of Indian population. That thefe circumftances, do in fact contain the caules, which rendered the population fo fmall among the favages, is confirmed from this additional evidence. Wherever the Indians have been placed in a fituation favourable to increale, they have become equally prolific as the defcendents of Europe. Several of the traders among the Indian tribes, have married with their women: When the Indian women have been thus provided with comfortable food, raiment, and places of abode, and relieved from the fatigues and diftreffes of the favage ftale, they have raifed up as large and numerous families, as are found in the houres of the white people.--And among themfelves, when a tribe was fitwated on the bank of a river abounding with fifh, or in a pot where the game was plenty, and they reznained undifurbed by their encmies; their numbers foon increaled, their women becarne more valued and efteemed, and population affumed a greater force and vigozr.

In lome parts of America, the Indians had advanced beyond the favage ftate, and acquired fome of the arts and conveniencies of the civil ftate. In Euch places, the fame increale of numbers took place anong them, that is feen among other nations. The intercourfe between the fexes approached nearer to e!elicacy and refinement. Greater attention was is aid to the women. The men became fenfible, how much their happinefs might be promoted, by the attachment and tendernefs of the female. In the empires of Peru and Mexico, the Indians had made confiderable advances to fuch a ftate: And their population had become vigorous and rapid. Their numbers refembled the appearance of things in Eurupe; and their cities abounded with inhabitants. Sisty thoufind families, were faid by Cortez, to be contained 
contained in the city of Mexico, when he led his band of ruffians againft it.-From thefe effects we may determine with certainty, that the defe in the Indian population, was not derived from any weaknefs, impotency, degradation, or defect of nature but arofe from a fituation, in which every circumftance was unfriendly to increafe, and multiplica. tion.

From the beardlefs countenance, and inattention of the Indian to the female, fome philofophers af great eminence and abilities, have formed the mof extravagant fyftems and theories. One has afferted that the Indian of America, has an inferiour conftitution to the European; that he is weak, and deficient in the organs of generation; without ardour, and impotent with the female ; and deftitute of natural affections to his wife and children.* Another is pofitive that he is not defcended from the com. mon parents of the whites, but is a diftinet, feparate, and infcriour order of men to them; of a different original, and fpecies.t And it feems to be generally afferted and believed, by the hiftorians who have quoted thefe accounts, that the man of America was of lefs force, energy, and vigour, than the man of Europe; and laboured under fome phyfical defee, or degradation.

The cleareft proof, and the moft unexceptionable evidence, ought to have been produced, before a philofopher admitted as facts, things fo repugnant to the general principles and laws of nature. Had this been attempted, it would have corrected the errour; for the facts are all in oppofition, to what has been fo often afferted, and quoted. No fuch animal was ever feen in America, as the Indian M. de Buffon defcribed in Paris. - If the facts had been

true,
* M. de Buffon, xviii. 146.
+ Kaims' Sketches Hift, of Man, Kol, I. Sketch I. Vol, LbB Sictoh 12 . 
true, the conclufions which have been drawn from them, would have been wholly uncertain. The want of a beard would have been no proof, that the Indians were incapable of population: $\Lambda$ nd the want of that exceffive licentious ardour, with which the negro and the libertine glows, is in no degree unfriendly to population. Every paffion carried to excels, tends to weaken and enervate the whole animal frame. In obedience to that temperance, purity, and regularity, which nature enjoins and requires, are we to look for the effects, which nature defigns. But the ardour produced by luxury, intemperance, and excefs, weakens its own powers, defeats its end, and deftroys its purpofe : Inftead of proving favourable to population, it tends to weaknefs, impotency, and the lofs of manhood. Is it not furprifing, that philofophers who had feen the debilitating and degrading effects, which luxury, intemperance, and excels, are conftantly producing in the populous cities of Europe; thould view the unnatural ardour they create, in any other, than an unfavourable light? Or fufpect the Indian was inferiour by nature to the European, becaule he did not appear to be governed by that unnatural ardour, which never fails to debilitate all the powers of nature : And which often ends, in the moft emaciated and degraded ftate, to which man can be reduced? Happily for himfelf, the Indian was without this unnatural ardour. Had it been added to the other unfortunate circumftances attending his fituation, it would have gone far to have deftroyed the whole race.

AVERgE TO ALL IMPROVEMENTS. -The moft fatal circumftance of all, was, the favage ftate was extremely averfe and oppofed to all improvements. It is with a benerolent defign, that nature reconciles and concilintes the mind of man, to that ftate in which it is placed. At the fame time, it has made us capablc of continual advance and progreffion, to greater 
greater improvements and perfection. So attached ivas the favage to the former, that he had no wilh or defire of the latter. Content and fatisfied with his own fate, he had 110 wifh, hope, or conception, that it could be changed for a better.-Accultomed to the molt perfect freedom and independence, he beheld with deteftation, the inequality of rank, and the fubordination eftablifhed among the Europeans. Free from all care, and without forefight, he was amazed at the anxiety, the care, and perpetual induftry of the white people: And could not conceive why they thould be thus perpetually adding hard larbour, to the other unavoidable calamities of life. The conftant lcencs of hurry, care, and bufinefs, in which they were employed, were objects averfe to all their feelings and wifhes: And what they viewed as the moft degraded condition, to which man could be reduced, was the bufinefs of agriculture, digging and labouring in the earth. The weapons of the Europeans appeared ufeful to them, and thefe they were at much pains to acquire. But moft of their arts, cuftoms, and manners, were greatly difagreeable to men, accuftomed only to the bufinefs of hunting and fighting.-Men thus fatisfied with their own condition, and averfe to that of others, could not be brought, but with great difficulty, to admit the improvements of the civilized life; or to give up that independence, which they efteemed the higheft diftinction, and the greateft glory of man.

The appetite for the hunter's ftate, is one of the mont general and powerful, that prevails in any period of fociety. Men never quit this ftate, until it becomes inadequate to their fubfiftence and fupport. It is in hunting and in filhing, not in agriculture and the arts, that the indolent and wealthy in the mort polifhed nations, find their farourite amulement and excrcife, - The children of the white poople, when Z. carited 
carricd among the favages in early life, have ofter contraeted fuch an attachment to that ftate, thas they could not be perfuaded to return, and refide among their friends. But nothing can reconcile the children of the Indians, to the cuftoms, manners, and methods of living among the Europeans: However careffed and indulged, they droop and languift, until they return to the freedom and wildnefs of the foref.

Nor was there any thing in the favage ftate, that could refine or improve itfelf. While the game continued, the fame method of living would have remained : And this would saturally have continued all the difadvantages, and habits of the favage ftate. The fame method of fupport, would have perpetuated the fame manners, maxims, and cufroins. Nothing would have led a people in fuch a fituation, to any improvements, until neceffity fhould have introduced agriculture; and forced them to become hufbandmen, inflead of remaining hunters.

Such were the difadvantages attending the favage ftate. They appear to have bcen infeparably connected with it: And of fuch a nature, as to prevent the improvement, progrefs, or increale of fociety. We need not hefitate to pronounce, that thefe difadvantages far exceeded any advantages that could attend it ; and operated with a certain and fatal tendency, to continue man in a fate of infancy, weaknefs, and the greatef imperfection. The freedom to which it led, was its greateft bleffing; but the independence of which the favage was fo fond, was never defigned for man : And it is only in the im. provements of civil fociet $\%$, that the human race can find the greaten increafe of their numbers, knowledge, fafety, asd happincls. 


\section{H A P. VIII.}

Obfervasions on the Origin of the Indians, their $B$ s. tiquity, Progress of Society, and Tendency to Diffolution.

\section{THE man of America differed in fo} many refpects from the men of other countries, that it has been made a queftion among fome of the modern philofophers, whether he was originally derived from the fame parents as the white men; or ought to be confidered as a different race, from the men of other countries. No inquiries have the appearance of greater difficulties than thole, which relate to the origin, and antiquity of the American Indians. Without attempting to refolve all the quaftions that have been propofed upon thefe fubjects, it may be of ufe to colled fome of the facts that feem to relate to them, and to note the conclufions to which they lead.

ORIGIN.- In whatever manner this part of the earth was peopled, the Indian or the Red Man, feems to have been the molt ancient, or the original inan of America. This race were by far the moft numerous; and they had fpread over the whole continent, from about the fiftieth degree of north latitude to the fouthern extremity of Cape Horn. This vaft extent of country, including all the variety of climates, was fettled with the red men : And thefe men, every where appeared to be the fame race, or kind of people - In every part of the con. tinent, 
tinent, the Indians were marked with a fimilarity of colour, features, and every circumltance of external appearance. Pedro de Cieca de L€on, who was one of the conquerors of Peru, and had travelled through many provinces of America, gives this account of the inhabitants : "The people, men and women, although there is fuch a multitude of tribes or nations as to be almoft innumerable, and fuch diverfity of climates, appear neverthelefs like the children of one father and mother."* Ulloa, an able philofopher, and an accurate oblerver, vifited and obferved many of the Indian tribes and nations, of Southamerica: He obferved alfo the Indians at Cape Breton, in Northamerica; and faith of the latter, that they were the fame people with the In: dians of Peru, refembling them in complexion, in manners, and in cuftoms; the only vifible difference, being, that the Indians at Cape Breton, were of a larger ftature than thofe at Peru. "If we have feen one American," faith he, "we may be faid to have feen them all, their colour and make are fo nearly the fame." + And it is worthy of remark, that no nation or people upon the earth, evcr have fpread over fo large a tract of country, as thefe red neen of America:

Were thefe men the fame people with the inhab. itants of the other parts of the glube?-Or did they radically differ from the men of all other countries? 1. They were of the fame complexion, with the moft ancient nation in Afia. From authentic documents, we are able to trace the exiftence, and national tranfactions of the Hindoos, to an higher antiquity, than we can find with certainty in any other nation. Thefe were the Indians, or red men of Afia. And the Indians of both continents, are marked with the fame

* Robertfon's Hift. America, Vol. 1I. p. 462. note 45.

+ Ulloa, Notic. Americanus, p. 308. 
fane peculiarity of colour. The difinguifhing colour of the Indian, is red, or rather a reddith brown; refembling, but more dark than a copper colour. From this fimilarity of complexion, it is natural to conjecture, that the Indian of A fia and of America belonged to the fame family. 2. The features and countenance of the American Indians, very much re. fembles thofe of another of the nations of $A$ fia, the Tastars. The Tartars join upon India, are fpread over the northern parts of Afra, and extend to the eaftern coants of the Pacific ocean. Of thcir appearance and countenance, geograplsess gire us this account: "They are in general ftrong made, flout men : Their faces broad, their nofes flatrith, their eyes fmall and black, but very quick."* "The Indians of America are thus defcribed, by thofe who had lived long among them : The limbs are well turned, the body of juft proportion, the countenance broad, their nofe flat, their eyes black, fmall, but capable of difceming objects at a great diftance." $t$ If thefe defcriptions had been taken from the fame individual, there could not have been a greater agree. ment, in every circumftance of afpect and counte. nance.

3. Some information refpecting the defcent of nations, may allo be derived from their cufoms. Thofe cuftoms and manners which arife from the wants, defires, and inclinations, peculiar to fituation and employment, will be the fame in the fame fate of fociety. A hunter in Afra, and a hunter in America, will have nearly the fame character, the fame occupations, purfuits, and manners. But thofe cuftoms which do not arife from fituation, or from any natural want or defire, may be termed arbitrary: And

\footnotetext{
* Guthrie's Geog. p. 66o.

+ Ulloa's and Pinto's account, Robertfon's Hif, Amer, 1. 460
} 
And the probability is, that two nations would not agree in the?e, unlefs they were derived from the one to the other. Several of thefe arbitrary cuftoms, were common to the men of Afia and America.

One of thele cufloms, was that of extracting their beards by the roots. 'The Tartars and the Americans, had both adapted this practice. Both of them appeared cither wholly without a beard, or only with a few fcattered hairs: And both of them made it their practice to extract or pluck them out with the roots. Something of the fame kind is practifed by the Chinefe. - The Tartar and the American had both contracted the fame wandering or roving difpofition, contrary to the cuftoms and difpofitions of mon hations; who feldom have any difpofition to defert their connexions and country, until they are compelled to it by neceffity or force. - They had both adapted the fame inethod of war ; walling, dentroying, and burning a country. The cuftom of fcalping the dead, was one of the barbarous habits the Scythians practifed. They cut a circle round the necks of thole which they had flain, ftripped off the $\mathrm{kin}$, ard carried it with them in triumph. In their marches, the Kamt\{chatkans never went a brean, but followed one another in the form of the Indian file.- The Tongufi, the mof numerous nation refident in Siberia, ufe canoes made of birch bark, diftended over ribs of wood, and nicely fewed together. In thefe cufloms they are exactly imitated by the Indians of America. - In burying the dead, many of the American nations place the corps at full length, others place it in a fitting pofture, and lay by it the moft valuable clathing, provifion, and arms. The Tartars did the fame; and both people agreed in covering the whole with earth, fo as to form a tumulus or barrow. - The method, in which both people treated their neareit friends and relations, "was fill more extraordinary and uncommon, when their ${ }^{*}$ 
their fathers and neareft friends were become extremely old and infirm, or were feized with a diftemper deemed incurable, it was the cuftom of the Tartars to make a fmall hut for the patient, near fome river, and to fupply it with a fmall quantity of provifions: Removing the fufferer to fuch a Gitua. tion, they left him to end his days, without vifiting or affording him any further relief. The rudef tribes of the Americans, in feveral parts of the continent, had the fame cuftom; and fometimes they made ufe of force to extinguifh the remains of life, in their difeafed and aged friends. Both people adapted this cuftom, oppofite to the practice of all other nations : And they both viewed it in the fame light, not as an act of cruelty, or of any difrefpect : but as a deed of duty, and mercy : And they both affigned the fame reafon for it: "They were kindly relieving their friends from the increafing and unavoidable miferies of life; and they were affifting them in their journey to the other country." Nor is it to be doubted but that they affigned the true reafon and motive, upon which they acted; for no people were ever known to pay a greater reverence to the aged, or were more enthufiaftic in the veneration they paid to the tombs and memories of their anceftors.

Such cuftoms are not derived from any natural appetite, or from any thing peculiar to the ftate of the hunter, or the favage; but muft be deemed extraordinary, uncommon, and arbitrary. Being found only among the men of Afia and America, the prefumption is, that they were derived from the one to the other; or that the latter had taken them from the former.

4. In the empire of Peru, there were feveral ap. pearances of Chinefe cuftoms and manners. The appearance, the drefs, and the fuperiour knowledge, of Manco Capac and Mama Ocollo; the knowledge 


\section{THE NATURAL AND CIVIL}

of agriculture and the arts, in which the one inftrueted the men; the knowledge of [pinning, knitting. weaving, and inaking garments of cotton, which the other diffufed among the women; the high eftima-. tion which the children of the fun affigned to agriculture, above all other arts and profeffions; their cuftom of tilling a field with their own hands; the ceremony with which the Inca began the bufinefs in the fpring; the feftivals which attended it: The unlimited authority of the emperor, with the patriarchal afpect of the government; the benevolent tendency. of their laws, and wars ; and their public regulations refpecting roads; bridges, canals, induf try, provifion for the poor and aged, and the refponfibility of parents for the conduct of their children; all, or molt of thefe articles, bore a greater refemblance to Chinefe maxims, manners, and cultoms, than could have been acquired in America, during the life of one man and woman, from their own obfervations and reafonings. They were advances towards a fate of civilization, that nothing in the degraded ftate of the Peruvians, could have fuggefted, or produced, but in a long period of time.

Much pains has been taken by many learned and ingenious men, to compare the languages of the Americans, with thofe of other nations. But while thefe inquiries have been carried on with great affiduity, the moft ancient language which prevailed in the eaft, the Sanfkreet, "the parent of almoft every dialect from the Perfian gulf to the China feas," "was itfelf wholly unknown : And no information has been derived from thefe inquiries.

We mult reafon then froin fuch circumftances as we can find: And if a judgment can be formed from

* Preface to the Grammar of the Eenga! Language, P. 3 . The filt tranflation from the Sanfkreet language was publificd in $1 ; 85$. 
a fimilarity of complexion, features, and cuftoms, we Inall be led to conclude that the then of America were the fame people with the men of Afia; but that their defcent, was not from any particular one, but from feveral nations on the eaftern continent.

No difficulty could ever have attended fuch emigrations. The continents of Afia and America approach fo near to each other, that the inhabitants are frequently paffing from the one to the other. The difcoveries of the Rulfians, and the greater difcoveries of the moft celebrated modern navigator, Capt. Cook, have made it certain that if the two continents are feparated at all, it is only by a ftrait, not more than eighteen miles in width. At no time within the period of hittory, was the navigation of the rudeft tribes unequal to the paffage of fuch a ftrait. And probably there never has been any difficulty, in paffing from the one continent to the other.

It is not improbable that the red men of Afia, might find a paffage into America altogether by navigation. "It has been long known that the Afratic nation called the Malayans, poffeffed in former times, much the largeft part of the trade of the Indies; and that their fhips frequented, not only all the coafts of A fia, but even thofe of Africa, and para ticularly the large illand of Madagafcar. It has been more lately difcovered, that the fame nation had extended their voyages and migrations from Madagafcar, to the Marquefas, and Eafter Ifland; that is, nearly from the eaft fide of Africa, until we approach the weft coaft of America. This fpace includes almoft one half of the circumference of the globe. Through this immenfe fpace the Malayans had fpread, made fettlements, and tounded colonics in the iflands at all the intermediate ftages, at an immenfe diftance from the parent continent. The voyages of Capt. Cook have afforded the proof of thefe hiftoriçal facts : And they have been alcertainA a ed 
ed not only by a fimilarity of manners and cuftoms, but by the affinity of language, and a collection of fimilar words, made from all the widely diffuled iflands and countries vifited by this celebrated navigator."

A people who had thus fpread over one half of the globe, from the coaft of Africa towards America, and who had fettled all the iflands that lay beiween them, could fcarcely have avoided arriving upon the weftern coalt of America, and leaving fom of her people there. Several of the inands thas were fettled, were near the American coaft; and it muft have been much eafier to have difcovered the continent, along the weftern coaft of Ainerica, than to have found lo many fmall and feattered iflands. It is therefore highly probable, that the fame people who fpread over the illands in the Pacific ocean, thould at times arrive alfo on the weftern fhores of the continent. - In both thefe ways, might poople from different nations in Afra, find a paffage into America, and at very differeat periods of time.

The ludians however, were not the only men: which appeared in America. Another race or kind of men were fettled in the northem parts of the continent. Thele have been called Efquimaur. In their colour, dimenfions, features, and cufoms, they differed much from the red men. 'T hey were of a. fallow, or brownifh complexion : Their fizc about four feet in height; their faces long and wrinkled; their nofes thick and compreffed; their eycs fmall. and funk; their cheeks much raifed; their eyebrows and eyelids thick; with finall legs and hands. This ration hat lpread over the moit northern parts. of America. They are found in Greenland, on the coatt of Labradore, in Huchon's hay, and in all the coafts and iflunds on the rieft fide of America, oppofite to Kamlfchatka. Their migrations had extendcd to Norton's foutid, Onolafhka, and Princ. William's 
William's found; one thoufand five hundred leagues from their ftations in Greenland and Labradore. The famenefs of the people in thefe different places, has been afcertained by their manners, cuftoms, features, and complexion; but more decidedly by fuch an affinity and fimilarity of language, as leaves no room for doubt. It will be eafy to determine from whence this nation of the Efquimalix procceded. Every thing in the appearance of this people, denotes them to be the fame with the Laplanders, the Zemblans, the Samojeds, and the Tartars in the eaft. Like them they are a na. tion of dwarfs ; largeft towards the fouth, but decreafing and dwindling towards the north. They have all the fame fallow complexion, deformed features, ugly appearance, and fingular cuftoms.-Whether the inhabitants, could pafs from the northern parts of Europe ints America by land, is as yet unknown. But the paffage by water, was at all times eafy ; and certainly, at a very early period. In the voyage from Norway to Iceland, and from I celand to Greenland, or the coaft of Labiadore, the firft part of the voyage was much the largeft: And this was practifed from the earlieit times, of which we have any. account. For the ninth century, when navigation was extremely imperfect, the paffage from Europe to America was fo well underftood, that the Norwegians planted and fettled their colonies in Greenland. There is but little room then to doubt, but that the nation of the Eqquimaux was derived from the fame people in the northweft parts of Europe. - Their defcent therefore muit have been from the Tartars of Afia, for it was from them, that the Laplanders, who are fpread over the northweftern parts of Eu. rope, were derived. In the year ${ }^{1769}$, Pere Hall, an aftronomer of Hungary, was fent into Lapland to obferve the tranfit of Venus. This able philof. opher had a good opportunity to become acquainted with the manners, cultoms, features, and language 
196 THE NATURAL AND CIVIL

of the inhabitants in that part of the globe: By his account, "it appears that the Laplanders are only de. generate Tartars; and that they, and the Hungarians, originally fprung from the fame breed of men, and from the fame country."*

The two kinds of men then that were in America, were derived from the fame fource. The Indians and the Efquimaux, were both defcended from the man of Afid; and probably the molt of them, from the lame nation, the Tartars.-In America then nature had not made different races of men, fitted for, and originally placed in different climates. The men of America were the fame with the men of $A$ fia: And both of thern migrated from one place to anoth er, and fpread through all the various climates of the eartb. They were diftinguifhed by the differences of complexion, dimenfion, features, arbitrary cuftoms, and peculiarities of manners, as much as the inhabitants are in other parts of the globe. But thefe differences muft have been derived from climate, food, manner of living, or fome other circumtance; for they certainly were not detived from a different origin, or any particular local creation.

The conflitution of man appears to be the fame, in every palt of the globe. Nature has given to him the fame phyfical and moral powers, capable of different degrees of impiovement, according to the fate of fociety in which he fhall be placed. But in no country, or part of the globe, does man appear to be an animal of climate, Among animals nothing is more apparent, than that fome are animals of climate; that is, they are fitted by nature and conflitution to fome particular part of the globe; where alone they can fubfint, multiply, and obtain their proper perfection. Thus the animals peculia: to the torrid and frigid zone, never have their parcicular climates out of choice; and when a change

Ekaims' Sketches of the Hift, of MIan, I. po 11. 
of climate is forced upon them, they degenerate, and walte away. It is evident that man is not fuch an anima!. He can multiply, and attain his proper perfection, in all the various climates of the earth. Nature has not furnifhed hirn with any kind of covcring, fitted to a hot, to a temperate, or to a cold climate : This is left to his own reafon and indultry, according as his fituation may require. Nor has nature affigned to him any particular, invariable colour. Black is the abfence or want, and white is the mixture of all colours: And thefe are the extremes between which, all the various complexions fall. Nature therefore has not affigned to man any covering, or any invariable colour, or any thing in his conftitution, that has fitted him particularly for the torrid, temperate, or frigid zone: But has given him a nature and conftitution, adapted to every climate. And in every climate which produces his proper food, the white, the red, and the black men, will fubfin, multiply, and attain their proper perfection. - If nature has thus made man the animal of all climates, would it not be altogether unphilofophical, to look out for local creations; or to introduce miraculous interpofitions of the Deity, to explain thole differences among men in other places, which in America, we are certain were derived from natural caules?

ANTIQUITY. - In attempting to eftimate the antiquity of the mott polithed nations, we can derive but little information from hiftory. No records, no monuments, no writings can be found, that reach back to fo ancient a period. Leaft of all is this to be expected from a race of favages, which had not the knowledge of letters. All the information we can obtain, muft be derived from fuch circumftances and events, as inply or denote certain periods of $y e a r s$; and of thefe there are but few, in the tranfactions of the favage ftate.

Some 
Some information may be collected from the exesent of the country they had fettied. The continent of America, in its dimenfions, amounts to one third part of the habitable globe. Over the whole of this concinent had the favages extended, when it was firf diícovered by Columbus, in the year 1492 . Their - fopulation had then attained its greateft perfection. No increale of their numbers has any where appeared to take place, fince that time. No circumftance or event has taken place during the three hundred years, that the Europeans have been acquainted with the Indians, which can lead us to fufpect that the favage ftate either has, or can admit of a greater population, than what it had already atrained. Nor is it probable, that any increale of numbers, and population, could have taken place, while hunting continued to be the method of procuring fubfifence.-From the obfervations that were made in Virginia, and Maffachuletts, it has been computed that the population of the Indians espon the fea coafts, could not be eftimated higher than one for every fquare mile. In the inland parts of the country, the indian population certainly did not exceed this. Geographers have computed the number of fquare miles in America, to amount to fourteen millions, onc hundred and ten thoufand, eight hundred and leventy four. We cannot make a nearer computation, than to fuppofe this was about the mumber of Indians it required in the hunter's Itate, to foread over the whole continent. - How long a period would it require, for the favages to increafe to fuch a number? There has been no inftance of a more rapid increale, than that of the Britilh colonies in America. They were aided by new emigrations from Europe: But fo much were they retarded and broke up in their rettlements by war, before the American revolution, that they did not in faet double their sumbers in thirly years. The families of the Ino. dians 
dians did not contain more than half fo many members, as thofe of the white people. The Indian population then will be highly eftimated, if we compute it to one half of that of the white inhabitants : and inftead of thirty, admit fixty years as the period of doubling. Affurning the population to have proa ceeded from one male and female, this would require : thirteen centuries and an half to have fpread over the whole continent, and produced one inhabitans: to every fquare mile. - The period of population: could not have been lefs than this. But probably this period was completed long before Columbus came into America. The Indians in feveral places, had gone out of the hunter's ftate. On the fea coaft: they were advancing into fomething like monarchy: In Mexico and Peru they were become extremely numerous, and had eftablifhed extenfive and powerful empires; the duration of which, could be traced back four or five hundred years. From their extent and population then, we deduce with fome degree of probability, that the Indians muft have been lettled in America eighteen centuries when $\mathrm{Co}-$ lumbus firtt difcovered the continent. This will carry us back three centuries before the chriftian era.

The number and variety of their languages implies and requires a much longer duration, and an higher antiquity. The Indians of America had not only fpread over the continent, but they had every where formed themfelves into a number of fmall tribes. If we may judge of the number of the fe tribes from what took place in Newengland, and Virginia, they muft have amounted to thoufands. Several of thefe tribes had fubfifted fo long in a national form, and as a diftinct people, that they had formed a partic ular language for themfelves. There were three 0 riginal languages fpoken in Canada; the Sioux, the Huron, and the Algonquin.* In Newengland, there

were

* Abbe Raynal, V. 10z. 
were one or iwo others.t In Virginia there were three, different from either of thefe I In Mexico thirty five were difcovered. In Southamerica there were ftill more. In Maraguon, the Portuguefe counted filty. In each of thefe places, the dialects were nearly as many as their tribes. And yet thefe places made but a fmall part of the continent. - What an immenfe period of time does this require? A language may be feparated into different dialects in a few generations: But for thefe dialects to recede fo far from one another, as to lofe all refemblance and affinity; and feveral new languages to be formed, radically differing from une another; could noc take place, or be effected, until the tribes had fubfitted for many centuries, as diftinct and feparate nations. - We cannot eftimate this procels by fixed periods of time, becaufe we have no facts from which a computation can be made. But it may be compared to the ftate and progrefs of things, in the other hemifphere: And we Shall find the number of languages radically differing from one another, more numerous among th.e Americans, than they were in Afia and Europe. Is not this an indication, that the red men of America are as ancient as the other nations of the earth? Learning and fience they had none: Bur nature, fituation, and neceffity, would operate as certainly, and as regularly upon them, as upon any other people. And would it not require as long a period of time to produce, and to form a language among the favages, as among any other people? This circumftarce feems to denote an antiquity, fully equal to that, which is claimed by any of the nations of the other hemifphere. Their antiquity may alfo be traced back to the time, when the mon uleful arts were unknown; and when

+ Hutchinfon, I. 457, 479.

\# Jefferfon's Notes on Virginia, p. 99.

"f Clavigero's Hift. of Mlexico. 
when the red men of Afra had not the ufe of the metals, or of domeftic animals. Some of the arts muft have been nearly coeval with the human race ; for neither food, raiment, or habitations, could be procured without fomething of them. Some of the arts have been gradually advancing, without owing much to any original inventor. And many of them are of fuch antiquity, that their origin and inventor: are beyond the reach of hifory. This is the cale with the molt neceffary and ufeful arts of life. The crigin of fpinning, and knitting, of the plough, the loom, and the forge, were more ancient than any of our hiftorical monuments, records, or traditions. But when thofe arts were invented, they never could be loft. Amidit the wars, changes, and revolutions, to which nations are expofed, what are called the fine arts may perifh and be loft. But no viciffitudes of human affairs tend to deftroy thofe arts, by which all men derive their fubfiftence; and which are equally neceffary to the conqueror and to the captive, to the oppreffor and to the oppreffed. The fame obfervation may be made with refpect to the ufe of domeftic animals. A people that have experienced the advantages derived from the food they afford, and from the labour they perform, would never lofe this kind of knowledge ; but endearour to apply it to fuch kind of animals, as they found irs the country to which they repaired.-O Of all there, the Indians of America were ignorant. They knew nat the ufe of the metals, fpinning, weaving, or the domeftic animals: They had derived no fuch know:edge from their anceftors, nor had they acquited it themfelves. At what period then, muft they have fettled in America? Before thefe arts were know in AGa. Before the Scythians became hubandmer, and before the mult neceffary and ufeful arts were known in the midnt of Afia. - Without attempting therefore to go back to the beginning of the creatinis $\mathrm{B}$ b 
of God, we can find circumfances that will cary $4 \mathrm{~s}$ as far back into antiquity, as any other nation can pretend. The hilfory and pretenfions of the Chirefe, do not imply or fuppofe any circumflances of greater antiquity, than thofe which have been mensioned. And it muft be from circumfances and facts, not from tradition, that we mult trace the antiquity and origin of ancient nations.

$\therefore$ :Progress op Society.-The progrefs of focie. ty among the Indians, would make a curious, and the moft ufeful part of their hiftory. The rudeft and moft fimple ftate that took place among them; was that which I have been defcribing. Wherefo: ever the favages continued to derive "their fupport from hunting, they continued from age to age in the fame condition, and made no improvements. Where the means of fubfifience were plentiful, and eafy to be procured, the Indians had advanced beyond the fate of an hunter, and began to increale their numbers, and their agriculture. In fuch places, fociety began to affume a different form, from what it bore in: their rudeft and moft fimple ftate. And the tendency of it was every where to monarcby.-In the fouthern parts of Newengland, and Virginia, fome of the tribes were advancing fant to the form of bercditary monarchy. In the botter climates it was already eftablifned. This was the cale in Floridi, among the Natchez on the Miffifppi, in Cubd, Hitpanicla, and all the large illands. In Bagota, Mexico, and Peru, monarchy had acquired its perfees form, its full powers, and a complete efablithnent. In each of thele places, the progrels of government had been from perfeet frcedom and independence, to almolt ab!olute and unlimited monarchy.-In the courfe of this progrefs, two remarkible phenomena appeared: In one part of America, an empire and a monarchy was eftablifhed, in moft refpects relem. bling thofe which had arifen in the other hemit. y

pliers. 
phere. In another part of America, an empire and a monarchy was produced, far fuperiour to thefe which were produced in the other parts of the globe.

In the empire of Mexico, almott every thing had taken the Afiatic, and European courfe. The great body of the people were reduced to a degraded and humiliating ftate; and held their lives, and performed their labours, under various names and degrees of degradation and abafement. A body ct nobility were poffeffed of ample territories, of great privileges, powers, and honours, under different: names and degrees. Above, and over all, was the monarch, enjoying fupreme power and dignity. After being elective during the reign of eleven of thei: fovereigns, the monarchy was become almoft abfolute and hereditary, in Montezuma. The fyftem of religion agreed perfectly well to the nature of the government: It was fevere, cruel, and barbarous; and delighted in the fprinkling and fhedding of blood: Human facrifices of all others were efteemed the moft acceptable, and availing; and the priefs had the privilege, the honour, and the profit, of announcing or removing the vengeance of the gods. This fyftem of monarchy had acquired a ftability, a regularity, and a vigour, equal to any monarchy that was then upon the earth. Upon comparing the fpirit of monarchy, untempered by reprefertation, in America, in Afia, and in Europe; the fpirit and the principles of it, will be found every where to have operated alike. It degrades the body of the people below the condition and $n$ ature of man. It exalts the nobles and the fovereign above the condition and ftate, which nature defigns or admits. In one form or another it has always been attended with a perfecuting, cruel, and bloody religion, put into the hands of a wealthy, and powerful priefthood. It has conftantly produced the fpirit of war and deAtruction; and generally derived to itfelf fecurity. wealth, 
wealth, and power, from the mifery, defruction, and Daughter, it has entailed on the human race. By placing the rulers in a fituation altogether unnatura), that is, above all fenfe of accountability to their fellow men, it has produced that conftant, fleady, and univerlal abufe of power, which, in every part of the globe, has been the diftinguifhing and certain effect of this form of government. Its fpirit and principle have every where been the fame; not the bonour which the great Montelquieu withed to afcribe to it, and wanted to find in it, but that total want of regard and accountability to man, which, with great accuracy and propriety, has been lately named a contempt of the people.

The empire of Peru was formed arid governed by a fpecies of monarchy, different from what-has ever taken place among any other people. Twelve fucceffive monarchs, for a period of more than four hundred years, had becn invefted with hereditary and abfolute power. They claimed this authority, not as derived to them in any inanner or degree from the people, but as the abfolute and exclufive donation of heaven. They amounced themfelves to be the children of the fun, and clothed with divine and unlimited power to aired all the civil and religious affairs of the prople. The fovereign was named Ince; and fo facred and pure were the family of the inca's, in the min $i s$ of the people, that they were univerfally eftecmed incapable of committing a crime, or falling into an errour: No other farnily might marry or mingle with it, for fear of polluting the heavenly blood. The people looked up to them, as to beings of a fuperiour and heavenly race: And all difobedience to them, was viewed not barely as a crime committed againft men, but as an act of re. bellion againft God.- The nobility of courle was nothing more than families of office. Though a difference of rank had taken place throughout the em. pire, 
pire, all but the chilizen of the fun, were fuppofed to belong to the common race of men. The people were well ciothed, and fed; cvery where diftinguinhed for their induftry, economy, moderation, contentment, and happinefs. Over this people, the incas; though abfolute in power, eftablifhed a government the rnof mild and gentle, that has ever taken place in any part of the earth. The morals of the people were lo pure, that few crimes were ever committed : The genius of the government was fo mild, that few punifnents were ever executed: And when they were, they were viewed as the neceffary acts of God, and not of men. Their government, the dominion of profperity and virtue, was efteemed by the people the dominion of God and his inca.-Their fyftem of religion, like their government, was mild, gentle, and pacific. The fun, the emblem of light, fereniiy, fertility, beneficence, joy, and life, was the object of their adoration. They offered to him a part of thofe productions, which they derived from cultivating the earth, enriched by his genial warmth. They prefented to him fpecimens of thofe works of ingenuity, which they had performed by his light. And they brought to him fome of thofe animals, which were nourifhed by his influence. But the inca never fained their altars with human blood; or admitted the favage idea, that the fource of beneficence could be plealed with the perfecution, cruel. $t y$, and deftruction of men.-Their fyftem of war partook of the fame fpirit of mildnefs, and wifdom. They fought not to exterminate, but to conquer: They conquered not to cnllave, but to improve, to civilize, and refine. No cruel torture awaited the captive... No barbarous marks of degradation, difgrace, triumph, or flavery, were referved for the prifoners. They were taught the fame fyftem of government and religion, as the reft of the people : They were admitted to the fame privileges; and treated 
treated with the fame lenity a:-d mildnefs. $\mathrm{Of}_{8}$ all the triumphs of the inca, the nobleft and the great? ent, was to diffufe the manifold bleffings of peace and happinefs, to the people whom they had fribdued. Such was the renius, the fpirit, and the effect, of the fy rem of monarchy that was eflablifhed in Peru. iVe need not hefitate to pronounce it fuperiour to any, that was then to be found upon the face of the earth. The genius and the fpirit of it, were above all cthers, mild and gentle: The olject and the aim of it, were in fact, the improvernent and the happine!s of the people. And if any government ever produced this effect, that government was the monarchy of Peru : Not the attainment of the moft polifhed nations of Afia, and Europe, of their, arts, fcience, and improvements; but of the greaver wif? dom and fimplicity of the Indians, and incas of A. merica.

We have bere a phenomenon, new, and almoft incredible in the political world. Ablolute, unlimited, and hereditary monarchy, which has never failed before or fince to prove one of the heavieft curfes, which has fallen upon mankind ; in Peru became imild, gentle, and beneficent : And was con: ftanlly employed during the reign of twelve fuccef. five monarchs, to refine, civilize, and improve the people; and to do the greateft good to mankind. And yet this was a fy fem not founded in truth, or in nature; but in delufion and fuperftition. What could give it a direction fo feady, uniform, and benevolent? Not the form, but the principle of it. It contained the beft and the pureft principle, that can enter into the nature of human government. Its origin, duration, and power, depended wholly upon the public fentiment. The inca claimed immediate defcent, and relation to the fun. The fun was the eriblem of peace; and benevolence. Had the monarcb fained his character by enormity in crimes and

vices, 
vices, or by a conftant abufe of power, nature would have taught the Peruvians that monfters in corrup: tion, vice, and cruelty, could not have been the fa: vourite children of the Deity. If the inca had been viewed in this light, all his divinity, and his power would have ended. His power was founded alto. getther in the opinion the people had formed of his divine defcent, qualifications, character, and virtues. So folicitous had the incas been to preferve this opinion, that through the whole period of their fucceffions, they had taken the moft fcrupulous care not to endanger or oppole it, by any bafe and unworthy conduct. And while they thus proved the conftan: friends and benefators of the people, the public eftem and veneration increafed. In the benevolencs. and urefulnefs of the inca, the people believed they, faw the children of the fun : And in the affections and opinions of the people, the Inca found an abfolute and unlimited power. But if his conduce had plainly difcovered that inftead of being the child of the fun, he was the child of folly, of vices. and abominable iniquity, his divinity, his power, and his empire would have ceafed with the public opinion.

Inftead then of being founded in a contempt of the people like the empire of Mexico, the monarchy of Peru had the fingular good fortune of being founded in the public fentiment. This rendered the inca accountable to the people for every part of his conduct : And this fenfe of accountability would keep a conflant fenfe of duty and character upon his mind. Thas under the form of ablolute hereditary. monarchy, the government of Peru had the uncom: mon advantage of excluding nobility with all its odious diftinetions and claims; and of embracing the beft and pureft principles, upon which civil government can ever be founded. The Indians leem ta have been the only yeople, among whom, 2 regazd 
regard to the public fentiment and benefit, did in fact conftitute the fpirit and principle of hereditary and abfolute monarchy.

TEndency to Dissolution.-However beautiful and promifing the progrefs of fociety once was among the Indians of America, it is now every where tending to decay and diffolution; and this has been its tendency, ever fince the firft arrival of the Europeans. In the deftruction of the empires of Mexico, and Peru, Cortez and Pizarro performed the molt accurfed tranfactions that ever were done by man. And wherever the Europeans have fetted, mifery, calamity, and deftruction, have been entailed on that unhappy race of men. The vices we have taught them, the difeafes we have fpread among them, the intemperance they have learnt of us, and the deftruction of their game, are evils for which the favage is unable to find a remedy. A contempt of our morals, a horrour at the knavery that has attended our commerce with them, and the conftant advances we have made into their country, have filled their minds with prejudices againt our arts and improvements. This, added to the frequency and bitternefs of their wars, to their conftant hardhips and fufferings, and to a defective popula. tion, but too plainly denote the event. The conftant wafte and decay of this people, mufi end in their total deftruction: According to the prefent courfe and tendency of things, in two or three centuries, the whole race inuft become extinct. - Inftead of wilhing for fuch an event, it would add to the glory of the United States to make a ferious attempt to prevent it. It has been the practice of arbitrary governmersts to fport with the liberties, and lives of men. A government of reafon and nature ought to attempt to. concilate the affections of a free, brave, independent, and grnerous pcople. It would be a grcater glo:y that we have ever yet attaincd, 


\section{HISTORY OF VERMONT.}

attained, if we could find out a way to impart the bleffings of the civil ftate, to a people whole greateft miferies and misfortunes have been derived from the luperiour arts, the policy, and the power of civ. ilized nations. 


\section{H A P. IX.}

Firft Setilement of Vermont by tbe Englifh. Grants from Newbamp/hire. Proceedings of Newyork. Tiolent Oppofition of the Settlers. American War. Declaration of the Freedom and Independense of the Staste.

\section{THE large and valuable tract of} country, which is now known by the name of Vermont, - was fituated, between the Newengland provinces, Newyork, and Canada. Its diftance from the Englifh fettlements along the fea coafts, and from the French on the river St. Lawrence, prevented any fettlements being made in it, at an early period, by either nation: But both of them, were making confant advances towards it. So early as the year 1615 , the Dutch had advanced one hundred and fixty iniles up Hudfon's river, and built a fort at Albany. In $16_{10}$, the French had extended far up the river St. Lawrence, and began their fettlements at Montreal. In 1635 , the Englifh began the town of Springfield, upon Connecticut river; and by 1670 , had extended as far up the river, as Deerfield. On September $3 \mathrm{~d}, 1696$, Colonel Fletcher, governor of Newyork, made a grant to Godfrey Dellius, a clergyman at Albany, of a tract of land on the eafe fide of Iudion"s river: This trate extended from the northernmon bounds of Saraloga, to the rock $R o f$ fian, (now called Split Rock, in the townfhip of Willeborough) about leventy miles in length, and in? width, 
width, twelve miles from Hudfon's river. In 1699 , this grant was declared by the government of Newyork to have been extravagant, and vacated on that account.*-In 1716 a tract of land was granted by the general court of Mafrachufetts, in the foutheaft part of the ftate, containing more than one hundred thoufand acres. But it was not until the year 1724 , that any fettlement was made, within the bounds of Vermont: The government of Maffachufetts, then built fort Dummer, upon Connecticut river. This fort, was then admitted to be within Maffachufetts, afterwards it was found to be in Newhamphire, and is now in Vermont. This was the firft fettlement, any civilized nation had ever made, in this ftate. On the oither fide of the ftate, the French made their advances up Lake Champlain, and in 1731, built their fort at Ciown Point, and began a lettlement on the eaft fide of the lake. This part of America became of courfe, the feat of war, and was conftantly expofed to the depredations of both nations, and their Indian allies.

The provinces of Maffachufetts and Newhampthire, had a long and tedious controverfy, refpecting their divifional line. This was not fettled until March 5. 1740; when George the fecond, determined, "that the northern boundary of the province of Maffachufetts be, a fimilar curve line, purfuing the courfe of Merrimask river, at three miles diftance, on the north Gde thereof, beginning at the Atlantic ocean, and ending at a point due north of Patucket falls; and a ftraight line drawn from thence, due welt, until it meets with his Majefty's other governments." This line was run in 1741, and has ever fince been ad. mitted as the boundary line, between Maflachufetts and Newhampihire. By this decifion, and the eftablifhment of this line, the government of Nervhampfhire concluded, that their jurifdiction exten 3 . ed

- Laws of Newyork, Vol, I. p. 32, Edit, 1774 . 
ed as far weft, as Maflachufetts had claimed and exercifed; that is, within twenty miles of Hudfon's river. The king of Greatbritain, had repeatedly recommended to the affembly of Newhamplhire, to make provifion for the lupport of fort Dummer; as a fortrefs, which had now fallen within their jurifdiction, and was known to ftand on the weft fide of Connecticut river. From thele circumfances, it was not doubted either in Britain, or in America, but that the jurildiction of Newhampinire extended to the well of Connecticut river; but how far to the welt, had never been examined, or called into queltion. Benning Weatwortb, was at that time governor of Newhampthire. In 1749, he made a grant of a townhip, fix miles fquare. It was fituated twenty miles eaft of Hudfor's river, and fix iniles north of Maffachufett's line. In allufion to his ow name, he gave to this townfhip, the name of Bennington. For the fpace of four, or five years, he made feveral other grants, on the weft fide of Connedicut river. In 1754, holtilities commenced beEween the Englifh, and the French in Anerica, which put a ttop to the applications and grants, and iflued in a war between the two crowns. In 1760 , the operations of the war, in this part of America, wcre terminated, by the furrencler of Montreal, and the entire conquet of Canada.-During the progrefs of the war, the Newengland rroops cut a road from Charleftown in Newhamplhire to Crown Point, and were frequerstly pafing through thefe lands; and their fertulity and value, became generally known. Upon the ceffation of lioflilities, they were eagerly fought after, by adrenturers and fpeculators. By the advice of his council, the governor of Newhampthire directed a furvey to be made of Connecticut river, for fixty miles; and three lines of townthips, to be laid out, on each fide. The application for lands conftantly increafed, and new furveys were made. 
made. So rapid was the progrefs, that during the year 1761 , not lels than fixty townfhips, of fix niles fquare were granted on the weft of Connecticut river. The whole number of grants, in one or two years more, amounted to une hundred and thirty eight: And their extent, was from Connecticut river, to what was efteemed twenty miles eaft of Hudfon's river, fo far as that extended to the northward; and after that, as far weft as the eaftern fhore of Lake Champlain. The cultivation of the country, and the number of the fettlers, increafed with a furprifing rapidity; and. Wentworth had an opportunity to accumulate a large fortune, by the fees and do. nations which attended the bufinefs, and by a referve of five hundred acres, which he made in every town. Ship for himfelf.

The government of Newyork intending to have the difpolal of the lands, was alarmed at thefe proceed. ings. Charles the fecond, in $166_{4}$, and 1674 , made an extraorcinary grant to his brother, the Duke of York; containing among other parts of America, "all the lands from the weft fide of Connecticut river, to the eaft fide of Delaware bay." T, This grant was inconfiftent with the chaiters, which had before been granted to Maffachufetts, and Connecticut ; and neither of them, admitted it to have any effect, with regard to the lands which they had fettled, or claimed to the weft of Connecticut river: And thero were no principles, which apply to human affairs, by which this grant would bear a ftrict examination. If it be examined geographically, the bounds of it were contradictory, indefinite, and impoffible. If it be fubjected to a legal conftruction, the whole of it, upon James's acceffion to the throne, merged in the crown; and at his abdication, paffed to William his fucceffor. If it be confidered as an inftrument of government, it did not eftablifh any colony or province of Newyork, or any power to govern any

fuch 
fuch province.-Upon this inadequate and blundering tranfaction of Charles the fecond, Newyork founded her claim, and hope, of obtaining the lands, which Newhamplhire was granting. To check the proceedings of Newhamplhire, and to intimidate the fettlers, Mr. Colden, lieutenantgovernor of Newyork, iffued a proclamation,* reciting the grants to the Duke of York, afferting their validity, claiming the jurifdiction as far eaft as Connecticut river, and commanding the theriff of the county of Alba. ny, to make a return of the names of all perfons, swho under the colour of the Newhamphire grants, had taken poffeffion of any lands to the weft of the siver. To prevent the effects that might arife from this proclamation, the governor of Newhampthire put forth another proclamation, $t$ declaring the grant to the Duke of York to be obfolete, that NewhampShire extended as far to the weft, as Maffachufetts and Connecticut, that the grants made by Newhamplhire would be confirmed, if the jurifdiction fhall be alcered; the fettlers were exhorted, not to be intimidated, but to be induftrious and diligent in cultivating their lands; and the civil officers were required, to exercife jurifdiction as far weftward, as grants had beer made, and to punifh all difturbers of the peace. This proclamation ferved to quiet the minds of the fetilers: And after fuch affurances fum a loyal governor, they had no idea that a contelt between two provinces, $r \in$ fpecting the extent of their jurifuiation, would ever affect the property of such udividuals, as had fairly purchafed their lands, under a charter from a royal government.

Newyork lad as yet founded her claim to the lands, upon the grant to the Duke of York; but that fagacious government did not choofe to rely, upon ro precarious a ground. Applications were made 
to the crown reprefenting that it would be greatly: for the convenience and advantage of the people; who wcre fettled weft of Conneeticut river, to be annexed to Newyork ; that the courfe of bufinefs mun always lie that way, and that the people were defirous to be included in that government.* The refult of thefe applications, was a decifion in favour of Newyork: On July $20: h, 1764$, his Majefty ordered and declared, "The weftern banks of the river Connecticut, from where it enters the province of the Maffachufetts bay, as far north as the forty fifth degree of northern latitude, to be the boundary line, between the faid two provinces of Newhampfhire and Newyork." This determination of the king, did not appear to be founded on any former grant to the Duke of York; but was a decifion, de novo; as the occabon, and convenience of the people, were fuppofed to require.

In this decifion of the boundary line, there was nothing alarming to the people, who had fettled on the new lands. They had no idea of difputing the jus sildiction, or oppofing the government of Newyork. They concluded the title to their lands, would not be in any way affected, by the decifion, but rather confirmed: And that the determination was expreffed in language, (to be) defigned to relate to the flssure, and not to any paft tranfactions, or time. Had the government of Newyork affigned the fame confruction to the royal decifion, no controverfy would ever have arifen; the fettlers would have remained quiet and eafy, under their jurifdiction. But a very different conftruction was put upon the royal determination, in Newyork. The government of that province

- The inhabitants complained that a petition was prefented to the king, figned with their names, but unknown to them. In their firft petition to Congrefs, Jan. 7, 1776, they give this account of the petition, "We have often heard, and vesily believo [it was] in your petitioners' names,". 
province conftrued it, as a declaration not only of what was to be, for the time to come, but of what was, and always bad been, the eaftern limit of Newyork: And of confequence, that the grants which had been made by the governor of Newhamphire, were grants of what had always belonged to New: york.

In conformity to this explanation, the grants from Newhamplhire, were confidered by the government of Newyork, as illegal, and of no authority. The new diftrict was divided into four counties: The fouthweftern parts, were annexed to the county of Albany; the northweft, were formed into a county by the name of Charlotte. On the eaft fide of the green mountains, two counties were formed; Cumberland, to the fouth; and Gloucefter, to the north; and in thefe, courts were regularly held. The fettlers were required to furrender the charters, which they had received from Newhampfhire, and to take out new grants from Newyork, which were attended with great fees, and expenfe. Some of the towns complied with this requifition, and bought their lands the fecond time, but the greater part refufed it: And where it was not complied with, on the part of the grantees, new grants werc made of their lands, to fuch petitioners, as would advance the fees which were derrianded. Actions of ejectment were commenced in the courts at Albany, againt feveral of the ancient fettlers; and the decifions of the courts, were always in favour of the Newyorkaproceedings, and againft all titles and grants, derived from the governor of Newhamphire.-The cafe of the fetlers did not admit of any relief, from the cuftomary forms of law; but only from the equity, the wifdom, and the moderation, of a provincial government: But moduation, and tendernels of the rights of individuals, unable to defend their claims, was not to be expered from ariventurers, and fpeculacors, who had 
had an opportunity to acquire what lands they pleafed, under the cuftomary forms of law, and government. The governor, and fome of the leading men in Newyork, availed themfelves of this ftate of things; and derived much more énormous profits, by making a fecond grant of the lands, than the governor of Newhamplhire had acquired, by making the firft.*

Although it proved an eafy thing for the claimants under Newyork, to recover judgment againft the fettlers, it was not found fo eafy a matter, to carry thofe judgments into execution. When the executive of ficers came to eject the inhabitants, from their houfes and lands, they generally met with an avowed oppofition, from the poffeffors; and were not fuffered, to proceed to the execution of their offices. The minds of the fettlers, inftead of being depreffed into fubmiffion, feemed to derive new powers, from oppreffion: And the people foon began to affociate, to defend one another, in their oppofition to the courts, and officers of Newyork.

When it was found, that there was an avowed oppofition and combination, againft the proceedings of the courts at Albany, an aitempt was made by the government of Newyork, to engage the militia to affift and fupport the fheriff. The people who were thus forced to march, in fupport of the fheriff, had no affection for the bufinefs: They, were rather in fentiment, with the fettlers; and had no dirpofition to hazard their lives, in fupport of a quarrel, which they plainly faw, was defigned only for the emolument of a few fpeculators; whofe claims and conduct, did not appear to them, to be fo jufti. fiable as thofe of the people, againft whom they were $\mathrm{D} d$ compelled

* The fees to the governor of Neswhampinire, for grantiog a townifhid, were about one hundred dollars; under the govern. ment of Newyork, they generally amcunted to two thoulasd or two thouland fix hundred dollars, 
compelled to take up arms. The theriff foon found that very little dependence could be placed on the poffe, which attended him: Upon the appearance of an armed oppofition from the fettlers, the Newyork militia could not be kept together, and the Theriff found his power, was no more availing, when he was attended with the poffe comitatus, than when he was without them.

This circumftance afforded much encouragement to the inhabitants, and they began to believe, they should find that fupport from the general fentiments of the people, in the adjacent ftates, which they could noc find from law. Their oppolition became more general, and daring; and fome of the officers of Newyork became fufferers, for attempting to carry into execution the judgments of their courts. In -this courfe, the difficulties and dangers were conftantly increafing, until feyesal on both fides were much abufed, and wounded; and no officer from Newyork, dared to attempt to difpoffefs any of the fettlers, of their farms. The actions of ejectment however, Atill went on, in the courts at Albany; but no atten. tion was paid to them, nor was any defeñce made by the fettlers; but they were never fuffered to be carried into execution: And when all ocher methods had failed, the mott active of the leaders, were indicted as rioters.

The main bodv of the fetclers at that time, confifted of a brave, hardy, intrepid, but uncultivated fet of men. Without many of the advantages of education, withove any ocher property than what hard tabour and hard living had procured, deftitue of the conveniences and elegancies of iife, and having nothing to foften or refine theis manners; roughnefs, excefs, and violence, would naturally mark their pro. ceedings, To deny fuch people juftice, was to prejudice and arm them againt it, to confirm all their fufpicions 
fufpicions and prejudices againft their rulers, and to give them an excufe and plea to proceed to outrage and violence. When the government of Newyork, gave to their proceedings, the names of mobs and riots, abufe and outrage to their officers, it is probable the expreffions conveyed pretty juft ideas, of the ap. pearance of their conduet, and oppofition to the laws. But when they called their oppofition, felony, rreafon, and rebellion againft lawful authority, the people of the adjacent provinces; feem to have believed, that the government of Newyork was much more blamable, in making and executing fuch laws, as called their titles to their lands in queftion, than the fettlers were, in acting in open and avowed oppofition to them.

In this fcene of violence, and oppofition to the pro. ceedings of Newyork, Etban Allen placed himfelf at the head of the oppofition. Bold, enterprifing, ambitious, with great confidence in his own abilities, he undertook to direte the proceedings of the inhabitants. He wrote and difperfed feveral pamphlets to difplay che injuftice, and defigns, of the Newyork proceedings: And fo oppreffive were thofe meafures, that although Allen was a very indifferent writer, his pamphlets were much read, and regarded; and had a great inluence upon the minds, and conduct of the people. The uncultivated roughnefs of his own temper and manners, feems to have affifted him, in giving a jutt defcription of the views and proceedings of fpeculating land jobbers: And where all was a fcence of violence and abufe, fuch a method of writing, did not greatly differ from the feelings of the fettlers, or from the tyle of the pamphlets that came from Newyork. But though he wrote with afperity, a degree of generofity attended his conduct; and he carefully avoided bloodhed, and protefted againft every thing that had the appearance of meannels, injuftice, cruelty, 
elty, or abufe, to thofe who fell into his power.Next to him, Setb Warner feems to have been the mont diftinguifhed, in thofe times. Warner was cool, firm, fteady, refolute, and fully determined that the laws of Newyork refpecting the fettlers, never thould be carried into execution. When an officer came to take him as a rioter, he confidered it as an affair of open hoftility; defended himfelf, at tacked, wounded, and difarmed the officer; but with the fpirit of a foldier, fpared his life.

So notorious and alarming had this controverly become, that the fettlers fent three of their moft active members, as agents to Greatbritain, to reprefent their fituation, and implore the protestion of the crown.* An inquiry was made into the nature and ground of their complaint; and the event proved favourable to their wifhes. In 1767 , the king in terpofed to ftop the proceedings of the governor of Newyork. Having recited a report from the lords of the trade and plantation affairs, he gave this royal order to the governor :t "His Majefty doth hereby Atriely charge, require; and command, that the governor or commander in chief of his Majefty's province of Newyork, for the time being, do not upon pain of his Majefty's highelt difpleafure, prefume 10 make any grant whatfuever, of any part of the lands defcribed in the faid report, until his Majefty's further plearure fhall be known concerning the fame." The fettlers were much encouraged by this royal mandate, and concluded it was defigned, and would be effectual, to prevent any further proccedings in regranting the lands. But they were foon full of complaints, that no regard was paid to it, that the bufinefs was purfued with the fame avidity as before,

* Merr. Samuel Robinfon, James Brakenridge, ard Mr. Hawley. + July 2 a. 
fore, and that the governors of Nervjork; while they srere calling upon them to obey the royal orders and decifions, paid no regard to thofe orders themfelves., It feems in fact to have been the cafe, that the bufinefs of making new grants of the lands, was too lucrative $a j$ jo, to be eafily or foon given up ; efpecially, when the crown could neither fully com. prehend, regulate, or controul it.

In $177^{2}, \mathrm{Mr}$. Tryon, governor of Newyork, made an attempt to conciliate the minds of the inhabitants, to that government. With this view * he wrote to the Rev. Mr. Dewey, and the inhabitants of Bennington, and the adjacent country, inviting them to lay before him the caufes of their illegal proceed. ings; affuring them, that both he and the council were difpofed to afford them fuch relief, as the fituation and circumftances of the people would juftify; and engaging full fecurity and protection, to any perfons they might choofe to fend to Newyork on the bufinefs, except Allen, Warner, and three others. Letters were written on this occafion to governor Tryon by the inhabitants, and by the except. ed perfons, in explanation of their conduct and principles; and Capt. Siepben Fay, and Mr. Fonas Fay, were chofen to wait upon the governor at Newyork, to negotiate the bufinefs. Upon their return, they reported that the governor received them with expreffions of kindnefs, and laid the flate of their grievances before the council; who made report, that they were defirous that his excellency fhould afford the inhabitants of thole townlbips, all the relief in his power, by fufpending until his Majefty's pleafure fhould be known, all profecutions in behalf of the crown, on account of crimes with which they flood charged; and fhould recommend it to the owners of the contelted lands, under grants from

- Newyork 
Newyork to put a ftop, during the fame period, to all civil fuits concerning thore lands.* - But no meafures or attempts of this kind, could avail, or be attended with any permanentiy good effects, while the original caufe of contention remained. The whole property of the fettlers, was the matter in contef. Their attempts to preferve this, appeared to them, not only juftifiable, but neceffary, and highly meritorious; as being defigned to preferve all, that man in any cafe, ever could have to defend. To the government of Newyork, their conduct appeared in a very different light, as acts of treafon, and rebellion, perpetrated by lawlefs and violent men, in open and avowed oppolition to the laws of their king and country.

While thefe different views of the controverfy remained, the meafures of both fides, inftead of operating to remove the caufes of contelt, tended to in creale the animofity, and to bring on a fate of more open holtility. So high had the fpirit of oppofition and refentment arifen, in the courfe of thefe proceedings, that in 1774 , the government of Newyork paffed an act, the moft minatory and defpotic, of my thing which had ever appeared, in the Britifh colonies. Among other extraordinary exertions of vinaictive power, it contained this fingular claule: "And in cale the faid offenders, thall not refpec. tively furrender themfelves purfuant to fuch orders of his excellency the governor, or of the governor and commander in chief for the time being, to be made in council as aforefaid; he or they fo neglecting or refufing to furrender himfelf, or themfelves as aforefaid, [i. e. within the fpace of feventy day's next after the fir $\mathrm{ft}$ publication of the order] frall, from the day to be appointed for his or their furrendery

- Allen's Narrative, po 49-6S.

+ Zuarclo o. Allen's Narrativc, p. $23-86$. 
furrendery as aforefaid, be adjudged, deemed, and (if indicted for a capital offence hereafter to be perpetrated) to be convicted and attainted of felony, and thall fuffer death, as in cafes of perfons convicted and attainted of felony by verdict and judgment, without benefit of clergy ; and that it thall and may be lawful to, and for the fupreme court of judicature of this colony, or the courts of oyer and terminer, or general gaol delivery, for the refpective counties aforefaid, to award execution againft fuch offender or offenders, fo indicted for a capital offence, perpetrated after the paffing of this act, in fuch inanner as if he or they had been convicted or attainted in the fupreme courts of judicature, or before fuch courts of oyer and terminer, or general gaol delivery refpectively." All crimes committed on the grants, were by this act fubject to be tried in the county, and by the courts at Albany. At the fame time, a proclamation was iffued by the governor of Newyork, offering a reward of fifty pounds a head, for apprehending and fecuring Ethan Allen, Seth Warner, and fix others, of the moft obnoxious of the fettlers.

With this act all profpect of peace, or fubmiffion to the government of Newyork, ended. At a general meeting of the committees for the townlhips, on the weft fide of the green mountains, it was refolved :* "That for the future, every neceffary preparation be made, and that our inhabitants hold themfelves in readinefs, at a minute's warning, to aid and defend fuch friends of ours, who, for their merit to the great and general caufe, are falfely denominated rioters ; but that we will not aft any thing, more or lefs, but on the defenfive, and always encourage due execution of law, in civil cafes, and alfo in criminal profecutions, that are fo indeed; and that we will affift,

- April 14, 1774. Page 22. 
affift, to the utmolt of our power, the officers ap. pointed for that purpole." The profcribed perfons carried the matter ftill further, and in an ad. drels to the people of the county of Albany, and athers who were fituated contiguous to the New. harnpthire grants, made this public declaration:* "We will kill and defroy any perfon or perfons whomfoever, that thall prefume to be accelTary, aid. ing or affifting in taking any of us."

To avoid the government of Newyork, a plan was contrived about this time; by fome of the inbabitants, and Pbillip Skeen, to have the Newhamp. Thire grants formed into a royal government, as a new pravince. Skeen, was a colonel in one of the king's regiments, and had large poffeffions on Lake Champlain. To effect his defigns, he went to the court of Greatbritain, and feems to have met with fome fuccels. On March $16 \mathrm{th}, 1775$, he wrote to one of the agents, that he was appointed to the gorernment of Crown Point, and Tyconderoga ; and thould foon call upon all the Hamplhire inhabitants, for an addrefs, to thew their loyalty to the king; and he had no doubt, but they would fhew themfelves to be as loyal fubjects, as he had reprefented them.t

An event took place in the fpring of the year 17.75, which ferved fill further to exafperate all parties. In corfequence of the proceedings of the Britiflecourt, the American colonies had met in Congrefs; Sept. 5, 1774 ; and the Congrefs had ad. viled the people to maintain their liberties, in fuch. ways as fhould be found necefrary. The courts of juftice; which'were held under the royal authority; in all the adjacent provinces, were either flut up,

* April 16. Page 45.

+ Skeen's letter to Capt. Inaryley, dxed bondon, March 16,1775 . 


\section{IIISTORY: OF VERMONT.LAV 225 :}

or adjourned without doing any bufinefs. The court in Cumberland county, was to have beeri holden at Weftminfter, on March i $3^{\text {th; } 1775 . ~ S o m e ~}$ of the inhabitants of that, and the adjacent towns, sook polreffion of the court houfe at an early hour; to prevent the officets of the court from entering. Being refufed admittance at the cuftomary time of opening the court, the judges returned to their quarters : About eleven o'clock at night, the fheriff with the other officers of the court, attended by an armed force, repaired to the court houfe. Being refuifed admittance, fome of the party fired in to the houfe, killed one man, and wounded feveral. The people were inflamed to the higheft degree, by this rafh proceeding: The next day they affembled in large numbers, from all quarters: A coroner attended, and a jury of inqueft brought in a verdict, that the man was murdered by the court party. Some of the officers were made prifoners, and carried to the gaol at Northampton; in Maffachufetts : But upon their application to the chief juftice of Newyork, they were releafed from their confiriernent, and returned home.*-Highly irritated by this event, the committees of a large body of the people met at Weftminfter, April $11 \mathrm{th}$, 1775: Among other meafures, they came to the following refolve: "That it is the duty of the inhabitants, wholly to renounce and refift the admin-iftration of the government of Newyork, until fuch time as the lives and property of the inhabitarits majp be fecured by it : Or until fuch time, as they canhave opportunity to lay their grievances before his moft gracious Majefty in council, together with a proper remonftrance again lt the unjuftifiable condu\&t of that government, with an humble petition to be taken out of fo oppreffive a jurifdiction, and E. e

either

* Narrative of the Maffacre at: Weftminfter court houfe, by Reuben Jones. 
cither annexed to fome other government, or ereet. ed and incorporated into a new one, as may appear beft for the inbabitants."*

Both parties were in this tate of relentment, and exalperation, when the American war broke out at Lexington, April 19th, 1775. By prefenting new fcenes, and greater objects, this event feems to bayo prevented either party from proceeding to boltilities; and turned their attention from their particulat conteft, to the general caufe of America. The aftention of all orders of men was immediately engaged; local and provincial contents were at once fwallowed up, by the novelty, the grandeur, and the importance of the contef, that then opened between Britain and America.

The enterprifing fpirit of Allen, foon found a nesi object for its employment. At the commencement of holtilities with Britain, fome of the principallead. ers of the American meafures, concluded it would. be a matter of much importance, to lecure the Britilh forts on Lake Champlain, before they thould get any intelligence of the American war. Arnold was fent from Connecticut, to engage the people on the Newhampthire grants, upon this expedition: Allen immediately undertook the bufinels, and in a few days raifed a body of troops, which were éfteemed fufficient for the purpofe : and marched with Arnold, or rather put himfelf at the head of the troops. He managed with bravery and fuccels, and took Tyconderoga and Crown Point, on May 10th. In the fall, he attended Montgomery at the - fiege of St. John's, but venturing to land on the illand of Montreal with a few men, he was taken prifoner by the Britifh, and fuffered many hardthips and abufes, during a long and levere imprifonment. Warrerilo

* Proceedings of the committees met at WeRminfter, April 11,1775 . 
Warner, who had allo been profcribed by the govornor of Newyork, entered with much fpirit into the American caufe. His attention, courage, and firmnefs; recommended him much to the officers, under which he ferved. Congreís withed to have a regiment compofed of the fettlers upon the grants: The command of it was given to Warner; and on every occafion he proved a brave, judicious, and excellent officer.

Amidft all the difficulties the people had paffed through, they had been without any form of civil government. The conteft with Newyork had now ceafed, and their attention was chiefly taken up, with the affairs of the war. The method in which they had managed their general concerns, was by meetings of towns and plantations, by committees, officers, and leaders, nominally appointed, and fubmitted to, by general confent and approbation. The people had been unable to raife any confiderable fums of money, on any occation; but the affairs of the war had fo multiplied emiffions of paper currency, that this difficulty was in fome meafure removed. But "the conftant difficulty and embarraffment, of conducting their public affairs without the advantages of government, had given rile to combinations of a general nature, among feveral of the towns ; and partial conventions had been holden at feveral times, and places, on each fide of the mountains. But no general plan of combination and union, had taken place; nor does it feem, that the people at this period of their affairs, had entertained the idea of furm ing themfelves into an independent ftate. But it had become a matter of general inquiry and converfation, What fhould be done? And what meafures ought to be adopted for the public fafety? - The fituation of the inhabitants at this time, feems to have approached nearly to what has been called by fome, - Itate of nature. A large number of people were 
fcattered over a large tract of country, in funall fettlements, at a great diftance from each other, without any form of government, any eftablifhed laws, or civil officers. Nature and neceffity had forced them to affociate, and to combine together, to promote their common fafety and intereft: But they had not entertaned the idea, of fetring up an independent government, or formed any plan for their future proceedings, or regulation. They feem to have been waitng, for the courfe of events to point out to them, what was practicable and prudent.

To obtain information, in the fall of the year 1775 , fome of the leading nembers went to Philadelphia, to procure the advice of Congrefs. They did no: obiain any formal act or advice from that body, but upon their return difperfed a number of letters, rep. refenting it as the opinion of feveral members of Congrefs, that the people fhould form a temporary affociation, and governinent by committees and conventions, as the circumftances of the people might require.-Accordingly, on January 16,1776 , a con. yention met at Dorfet, and drew up a petition to Congrefs. Their application they ftiled, "The humble petition, addrefs, and remonftrance of that part of America, being fituate fouth of Canada line, weft of Connecticut iver, commonly called and known by the name of the Newhampflaire grants." They avow their readinefs to bear a full proportion of the American war, their ability and zeal in the common caufe, and a willingnefs to be called upon for this purpole, whenever Congrels thould judge it neceffary: But declare they are not willing to put then felves under the provincial government of Newyork, left it hould be afterwards comftrued to imply an acknowledgment of that authority. They conclude with requelting, that whenever the Congrefs thould find it neceffary, to call for their fervices, they pay not be called upon as inhabitants of Newyork. 
or as perfons fubject to the limitations, reftictions, or regulations, of the militia of that province; but as inhabitants of the Ncwhamplhire grants; and that whatever commifions, might be granted to ary af the inhabitants, might confider them in that view.*

This was the fir?t application, the people had ever made to Gongrels. The committee to whom it was referred, Ireported as their opinion, that it be recom. mended to the petitioners for the prefent, to fubmit to the government of Newyork, and to affint their countrymen in the conteft with Greatbritain; but that luch fubmiffion, ought not to prejudice their right to any lands in controverfy, or be conftrued to affirm or admit the jurifdiction of Newyork, over the country, when the prefent troubles thould be ended. - This advice was fuch, as might have been expected: At a period when the fate of all the American colonies was at ftake, the committee could not but wifh, that all local or provincial controverfies might fubfide: To avoid any decifion upon the matter at that time, the petition was withdrawn.

On July the $4^{\text {th }}, 177^{6}$, the Congrefs made a dec. laration of Independence; declaring in the name, and by the authority of the people of the United Colo. nies, that they were, and of right ought to be, free and independent ftates; that they were abfolved from all allegiance to the Britifh crown, and that all political connexion between them, and the kingdom of Greatbritain, was totally diffolved. By this found and decifive policy, the United Colonies were delivered from the embarraffments, with which they had before been perplexed. It was no longer of any importance to them, what were the powers and prerogatives of the crown; or what was the origin, or extent of liberty, under the Britifh conftitution. One queftion only, remained to be decided; and that was,

* Firft petition to Congrefs, dated Dorfet, Jan, 17,1776 . 
was, Whether for the future, they were to be conquered provinces, or free and independent ftates?

But while the declaration of Independence, clearly ftated to the United Colonies, the ground on which they were to ftand; it left the people, on the Newhamphire grants, in a fituation more uncertain and critical, than that, in which they had been before. Co!. Skeen had obtained a commiffion from the crown, to be governor of Tyconderoga, Crown Point, and. the adjacent country; but to what extent, was unknown. Newhamplhire had rerrounced all political connexion with them. The controverfy with Newyork was reviving. The convention of that fate had unanimoully voted on Auguft 2d, 1776, "That all quitrents formerly due to the king of Greatbritain, are now due, and owing to this convention, or fuch future government as fhall hereafter be eftablifhed in this thate."* To fubmit to the claims of Newyork, was to give up the whole of their property, and to reduce themfelves to a ftate of dependence, and beggary. To oppofe her claims and power, would probably bring on, not only a conteft with Newyork, but with the Congrefs alfo: And to con-? tinue without fome form of government, was impoffible.

A fitration attended with fo many difficulties, gave zife to a variety of opinions. Some were for attempting to return to Newhamplhire: Others faw no other method of proceeding, but fubmiffion to Newyork. The more relolute, were for affuming the powers of government, and hazarding all the confequences of , fuch a meafure. To afcertain what the prevailing opinion

* In the grants made by the governors of Newhamplhire, the annual quitrents referved to the crown on every hundred acres, were one thilling proclamation money, equal in value to nine fence fterling; in the grants made by the governors of Newyork, thefe quitrents were railed to two thillings and fix pence !terling. 
opinion was, it was judged neceffary to call a general covention. This convention was called by circulardetters, from fome of the moft influential perfans; it confifted of fifty one members, reprefenting thirty five towns, and met at Dorfet, July $24 \mathrm{th}, 1776$. At this feffion, the convention agreed to enter into an affociation among them?elves, for the defence of the liberties of their country : But that they would not affociate with either of the counties, or with the provincial Congrefs of Newyork; and that any of the inhabitants of the Newhamplhire grants, who Thould enter into fuch an affociation, thould be deemed enemies to the common caufe.

The fentiments of the people, were now very generully tending, towards a total feparation from Newyork. On September the $25^{\text {th }}$, the convention met again, and refolved without any diffentient vote, "to take fuitable meafures as foon as may be, to declare the Newhampthire grants, a free and feparate diftrict." - And that "no law or laws, direction or directions from the ftate of Newyork, fhould be accepted."

In January 1777 , a general convention of reprefentatives from the towns on both fides of the mountains met at Weftminlter. The fentiments of their confituents, were now, well known : And after a very ferious debate and confultation, the convention concluded that there was no other way of fafety left, but to form themfelves into a new ftate, and affume all the powers of government. Accordingly, on January 16 th, having refolved upon this meafure, they made and publifhed the following declaration :

"This convention, whofe members are duly chofen by the free voice of their conftituents, in the fevcral towns on the Newhampfhire grants, in public meeting affembled, in our own names, and in behaif of our canflituents, Do hereby proclaim, and publicly declare, that the diftriet of territory compre. hending 
hending, and ufually known, by the name and defcription of the Newhampfhire grants, of ripht ought to be, and is hereby declared forever hereafter to be confidered as a free and independent jurifdiction, or flate ; to be forever hereafter called, known, and diftinguifhed, by the name of Newconnecticut, alias Ver. nont: And that the inhabitants that at prefent, or that may hereafter become refident within faid territory, fhall be entitled to the fame privileges, immunities, and enfranchifements which are, or that may at any time hereafter be allowed, to the inhabitants of any of the free and independent fates of Ameri$\mathrm{ca}$ : And that fuch privileges, and immunities, fhall be regulated in a bill of rights, and by al form of government, to be eftablifhed at the next feffion of this convention." **

Having taken this decifive flep, they.drew up a declaration and petition to Congrefs, in which they announce to that body, as the grand reprefentative of the United States, that they had made and publifhed a declaration, "that they would at all times thereafter, confider themfelves as a free and independent ftate, capable of regulating their own inter. nal police, in all, and every refpect whatfoever; and that the people in the faid defcribed diftrict, had the fole exclufive right of governing themfelves, in fuch manner and form, as they, in their wifdom, fhould choofe; not repugnant to any refolves of the honourable, the continental Congrefs:-And that they were at all times ready, in conjunction with their brethren in the United States, to contribute their full proportion towards the maintaining the prefent juft war, againft the fleets and armies of Greatbiitain." + They petition Congrefs that their declaration might be received, that the diftrict therein delcribed, might be ranked among the free and independent

- Records of the Convention.

+ Copy, attelted by J. Fay, cletk. 
pendent American States; and delegates therefrom; be admitted to a feat in Congrels. This declaration and petition was figned, and prefented to Congrels in behalf of the inhabitants, by four of the moft refpectable members' of the convention; Fonas Fav, Tbomas Cbittenden, Heman Allen, and Reuben Fones.

No meafure was ever more neceffary, or more hap. pily chofen, than this. "Newhamplhire had wholly rejected them. They never had fubmitted to the government of Newyork, but fteadfaftly oppofed her authority. By the diffolution of all connexion with the crown of Greatbritain, they concluded they were no longer fubject to the claims of Newyork, founded on the arbitrary decifions of that crown. The period was now come, when as they expreffed it, they were reduced to a ftate of nature. Some form of government, mult be adopted. They had the fame right to affume the powers of government, that the Congrefs had. The ftep feemed to be abfolutely neceffary, for the immediate fafety and protection of the people: And now was the time, when the powers of government could be affumed, with the greateft fafety and advantage. To be irrefolute or timid, was to lofe an opportunity, which mighe never return: And whatever oppofition might be made to their meafures, they could meet it with greater force, when they had declared themfelves a free and independent ftate, and knew by what authority they acted. Every part of the United States, was at tha: period, contending againft oppreffion; and every confideration that could juftify the proceedings of Congrefs, was a reafon, why the people of Vermont, thould take that opportunity, effectually to guard againtt their former fufferings. Happily for them-. felves, and for the fate, they adapted that firm and temperate policy, which alone was adequate to the objeet. 


\section{$C H A P . X$.}

Proceedings of Newyork. Refolvesiof Congrefs. Cusstroverfy witb Newbamp/ire. Claims of NewbampBire, Newyork, and MaJjacbufetts. Appoiniment of Commifloners, to confer with the Inbabitants. Interpofition of Congrefs. Conduct of Vermont. Meafures purfued by Congrefs. Furtber Clainss of Vermont. Proceedings and Views of the Britifs Generals, and Minifters. Refolutions of Congrefs. Proseedings of Vermont, Nereyork, and Newbampßire. Advice of General Wapington. Proceedings of Vermont. Votes of Congress. Remarks on the Defign, and Effect of those Votes.

\section{THE conduct of Vermont in declar.} ing their independence, was viewed by the adjacent ftates, in very different lights. Newhampthire appeared willing to admit, and acknowledge it. In Maffachufetts and Connecticut, the meafure was rather applauded, than condemned. But to Newyork, the conduct of the people in attempting to form a new ftate, appeared as a dangerous revival of their former oppofition and rebellion to lawful au. thority.

The committee of fafety for that ftate, were then fitting. Apprehenfive of the confequences, they immediately took up the matter ; and by their direction, the prefident of the Newyork convention, on January 2oth, 1777, gave this information to. Congrefs, "I am directed by the committee of fafery of

Newyork, 
Newyork, to inform Congrefs, "that by the arts and influence of certain defigning men, a part of this Rlate hath been prevailed on to revolt, and difavow the authority of its legillature.-The various evidences and informations we have received would lead us to believe that perfons of great influence in fome of our fifter ftates, have foftered and fo. mented thefe divifions. - But as thefe informations tend to accule fome nembers of your honourable body, of being concerned in this fcheme, decency obliges us to fufpend our belief - The convention are forry to obferve, that by conferring a commiffion upon Col. Warner, with authority to name the officers of a regiment, to be raifed independently of the legiflature of this ftate, and within that part of it, which hath lately declared an independence upon it, Congrefs hath given but too much weight to the infinuations of thofe, who pretend that your honourable body are determined to fupport thefe infurgents; efpecially, as this Col. Warner, hath been conftantly and invariably oppoled to the legiflature of this Itate, and hath been, on that very account, proclaimed an outlaw by the late government thereof.-It is abfolutely neceffary to recall the commiffions given to Col. Warner, and the officers under him, as nothing elfe will do juftice to us, and convince thofe deluded people, that Congrefs have not been prevailed on to affift in difmembering a ftate, which of all others, has fuffered the molt in the common caufe."* To perfuade Congrefs to engage in this caufe, another application was made to that body, on March the $1 \mathrm{ft}$ : In this the convention of Newyork reprefent, that they depend upon the juftice of that honourable houfe, to adapt every wife and

- Atteftod copy of a letter from the Honourable A. Tern Broek, prefident of the convention of Newyork, dated Jar, 20,3777 . 
and falutary expedient, to fupprefs the mifchiefs which muft enfue to that ftate and to the general confederacy, from the unjuft and pernicious projects of fuch of the inhabitants of Newyork, as mercly from felfifh and interefted motives, have fomented the dangerous infurrection: That Congrefs inight be affured that the ipirit of defection, notwithftand. ing all the arts and violence of the feducers, was by no means general: That the county of Gloucefter, and a very great part of Cumberland, and Charlotte counties, continued fteadfalt in their allegiance to the government of Newyork; and that there was not the leaft probability, that Col. Warner could raife fuch a number of men, as would be an object of public concern.*

The proceediugs of Vermont had now alfumed a regular form, and become an object of general attention. In April, a paper was printed at Philadelphia, fubfribed Thomas Young, and addreffed to the inhabitants of Vermont: To this, addrefs was prefixed a refolution, which Congrefs had paffed May ${ }_{15}, 1776$, recommending to the refpective af. femblies and conventions of the United Colonies, where no government futficient to the exigencies of their affairs had been already eftablifhed, to adopt fuch government, as in the opinion of the reprefentatives of the people, fhould beft conduce to the bappinels and lafety of their conftituents. In the addrefs to the inhabitants of Vermont, were thefe paragraphs: "I have taken the minds of feveral leading members, in the honourable the continental Congrefs, and can affure you, that you have, nothing to do, but to fend attefted copies of the recommendation to take up government to every townfhip in your diftrict, and invite all your freeholders and inhabitants to meet in their refpective townhips, and chooie

Q Tetter from A, Ten Broek of March 1, 1777 , 
choofe members for a general convention, to meet at an early day, to choole delegates for the general Congrels, a committee of lafety, and to form a confitution for your itate. Your friends here tell me, that fome are in doubt, whether delegates from your diftrict, would be admitted into Congrefs. 1 tell you to organize fairly, and make the experiment, and I will enlute your fuccels, at the rifk of my reputation as a man of honour or common fenfe. Indeed they can by no rneans refule you! You have as good a right to choofe how you will be governed, and by whom, as they had."**

Publications and meafures thus avowing the caufe, and defigned to eftablifh the independence of Vermont, were beheld by Newyork, with great indignation and concern. On May the 28th, the coupcil of fafety for that ftate, made a third attempt to engage the attention of Congrels : By their direclion, their prefident wrote to that body, that a report prevailed and daily gained credit, that the revolters were privately countenanced in their defigns, by certain members of Congrefs ; that they efteemed it their duty to give them fuch information, that by proper refolutions on the fubject, Congrefs might ceale to be injured, by imputations fo difgraceful and difhonourable. "However unwilling we may be to entertain fufpicions fo difrefpectful to any member of Congrefs, yet the truth is, that no inconfiderable numbers of the people of this ftate, do believe the report to be well founded." $t$

To bring Congrefs to fome decifion upon the matter, on June $23 \mathrm{~d}$, one of the delegates of Newyouk laid before that body, the printed letter and publication of Thomas Young. Congrefs took up

the

* Printed letter to the inhabitants of Vermont, April $1 \mathrm{r}$, 1777, by T. Young.

t Pierre Van Cortlandt's letter to Congrors, May 28, 1777. 
the matter, and ordered the printed paper, the letters which had been received from the convention of Newyork, and from the inhabitants of the Newhamplhire grants, to be referred to a committee of the whole; and after feveral adjournments, on June 30 th, paffed the following refolves :

"Refolved, That Congrefs is compofed of delegates chofen by, and reprefenting the communities refpectively inhabiting the territories of Newhampfhire, Maffachufetts Bay, Rhodeifland and Providence Plantations, Connecticut, Newyork, Newjerfey, Pennfylvania, Delaware, Maryland, Virginia, Northcarolina, Southcarolina, and Georgia, as they refpectively flood at the time of its firft infitution; that it was inflituted for the purpofe of fecuring and defending the coinmunities aforefaid, againft the ufurpations, oppreffions, and hoftile invafions of Greatbritain ; and therefore it cannot be intended that Congrefs by any of its proceedings would do, or recommend, or countenance, any thing injurious so the rights and jurifdiction of the feveral communities, which it reprefents.

"Refolved, That the independent government attempied to be eftablifhed by the people, ftyling themfelves inhabitants of the Newhampihire grants, can derive no countenance, or juatification, from the act of Congrefs declaring the United Colonies to be independent of the crown of Greatbritain ; nor from any other act, or refolution of Congrefs.

"Refolved, That the petition of Jonas Fay, Thomas Chittenden, Heman Allen, and Reuben Jones, in the name and behalf of the people, ftyling themfelves as aforelaid, praying that 'their declaration that they would confider themfeives as a free and independent flate, may be received; that the diftrict in the faid petition defcribed, may be ranked among the free and independent ftates; and that delegates therefrom 
therefrom may be admitted to feats in Congrefs, be difmiffed.

"Refolved, That Congrefs by raifing and officering the regiment, commanded by Col. Warner, never meant to give any encouragement to the claim of the people aforefaid, to be confidered as an independent ftate; but that the reafon which induced Congrefs to form that corps, was, that many officers of different ftates, who had ferved in Canada, and alledged that they could foon raife a regiment, but were then unprovided for, might be reinftated in the fervice of the United States."

Having recited the paragraphs in the letter from Thomas Young, which have been quoted, they next. refolve, "That the contents of the faid paragraplis, are derogatory to the honour of Congrefs, are a grofs mifreprefentation of the refolution of Congrefs therein referred to, and tend to deceive and miflead the people to whom they are addreffed."*

Thefe refolves were favourable to the government of Newyork : From their fpirit and ftyle, and the manner in which the bufinefs was introduced, the people of Vermont concluded, they were drawn up under the influence of that ftate; and that their independence muft be fupported, with the fame firmnefs and fpirit, with which it had been declared: And they ferved only to confirm the refolution of a people, who with all the hardihood of antiquity, were well acquainted with the nature and origin of their own rights.

During this period, no controverfy had arifen with Newhamphire. That ftate had gone farther than any other, to admit and acknowledge the inde. pendence of Vermont. - On the 6th of July, 1777. the American army ftationed at Tyconderoga, was forced to abandon that important poft to the formidable

* Journal of Congrets, June, 2777, P. $258,259,268$. 
dable army commanded by General Burgoyne. The people in mott of the towns on the weft fide of the mountains, were obligged to abandon their habitations, with circumftances of great diftrels and confufion.

The convention of Vermont was then fitting, at Windfor. Their committee wrote in the moft preff. ing terms, * to the committee of fafety at Exeter in Newhampthire, for affiftance; informing them at the fame time, if none thould be afforded, they mutt immediately retire into the Newengland ftates, for fupport and fafety. The affembly of Newhampthire was immediately called together : They put a large body of their militia under the command of General Stark, and gave him orders to "repair to Charleftown on Connecticut river; there to confult with a committee of the Newhamplhire grants, refpecting his future operations, and the fupply of his men with provifions; to take the command of the militia, and march into the grants; to act in conjundion with the troops of that new ftate, or any other of the ftates, or of the United Statcs." + About the fame time, 4 r. Weare prefident of NewhampThire, in behalf of the council and affemb!y, wrote io Ira Allen, fecretary of the ftate of Vermont, announcing the affiftance they were fending; the ftyle and expreflions of his letter were addreffed to Vermont, as a free and fovereign, but a new ftate. From thefe events it was not doubted in Vermont, but that Newhamphire had already acknowledged her independence; and would ufe her influence, to have it acknowledged by Congrefs.

But the conduct of fome of the inhabitants of Newhampline, foon occafioned a controverfy of a very

* July $\delta$.

t Belknap's HiRcry of Newhampfhire, Vol, II. 119.

\pm July ig." 
very ferious nature, with that fate. Newhamphire was originally granted as a province, to John $\mathrm{Ma}$ fon; and was circumfcribed by a line, drawn at the diftance of fixty miles from the fea. All the lands to the weflward of that line, were properly royal granes, and had been annexed to Newhamprhire, by force of royal commiftions. The intiabitants on the eaftern fide of Connecticut river, well knew what the original bounds of Newhamphire were; and they were defirous to join the inhabitants on the weft fide of the river, in fetting up a new ftate.-With thefe views, it was not a difficult thing, to find reafons to juftify their proceedings. They urged, that the province of Newhamphire could not originally extend further, than fixty miles from the fea coaft: That the additional towns were annexed to that ftate, folely by virtue of the royal commiffions : That thefe commiffions could be of force, or operate no longer, than while the power of the crown fubfifted : That as all royal authority was done away, the obligations whick had annexed them to the province of Newhamphire, was done away with it: And that it now belonged to the people to determine, what ftate they would join, and what government they would be under.* Thefe ideas.were propagated with much fuccers, in the towns adjoining Connedticut river; conventions were holden, and in the courfe of a few months, t a petition was prefented in the name of fixteen towns in Newhamp?hire, announcing "that they were not connected with any ftate, with refpect to their internal police," and requefting the ftate of Vermont, to receive them into an union and confederation with shem.

$$
\text { Gg The }
$$

* Oblervations on the right of jurifdiction of Newhamp. Mire grants: Prinled 1773 . Public defence of the right of Newhampthire grants, \&c. Prinied 1779.

+ March 12,1778. 
The affembly of Vermont was perplexed with this application. Mont of the members from the weft fide of the mountains, viewed it as a dangerous meafure; and the majority of the affembly, appeared to be againft receiving any of the lowns from Newhampthire. The towns in Vermont which adjoined to Connecticut river, were generally in favour of receiving the towns from Newhampfhire; and went fo far as to propofe withdrawing from theis connexion with Vermont, and fetting up another ftate. There was no method to prefervẹ their own union, but to refer the queftion to the decifion of the people : And the party in favour of the New hamplhire propofals, were extremely diligent and active, in fecuring a majority of the members, againt the next meeting of the affembly. When the affembly met, it was reprefented to them, that the in habitants of the towns which had applied for a union with Vermont, were almof unanimous in their votes, and that Newhampthire, as a fate, would not object againft faid towns joining with Vermont.* $A$ vote was carried in favour of their union and confederation :t And the affembly of Vermont refolved further, That any other towns on the eaft fide of Connecticut river, might alfo be admitted into the union, on producing a vote of the majority of the inhabitants, or on their fending a reprefentative to the affembly of Vermont.-lifaving thus effecled their purpores, the fixteen towns announced to the government of Newhampthire, that they had withdrawn from their jurifdiction, and wilhed to have a divifional line eftablifhed, and a friendly correfpondence kept up. +

\section{Thefe}

* Allen's vindication of the conduct of the general alfembly, \&c. page 13 .

+ June 11,1778 .

$\ddagger$ June 25 . 
Thefe proceedings were founded upon principles, which might introduce endlefs contentions and divifions, among the United States; and they juftly proved greatly alarming to Newhampfhire.

Mefpeck Weare, Efq; was at that time prefident of that ftate, a gentleman of great wifdom and virtue. In the name of the affembly he wrote to Mr. Cbittenden governor of Vermont, * claiming the fixteen towns as part of the ftate of Newhampthire. His claim was founded on the known boundaries of that ftate, before the revolution; on their fending delegates to the convention, in 1775 ; on their applying to the affembly of Newhamphire, for arms and ammunition; on their receiving commiffions from the government, and lyaving always acted as a part of it. He gave information at the fame time, that the minority in thofe towns, had claimed protection from that ftate; which the affembly of Newhamplhire, viewed themfelves as bound on every confideration, to afford. And he urged the governor of Vermont, to exert his influence with their affembly, to diffolve fo irregular and dangerous a connexion. - That he might avail himfelf of the higheft authority in A merica, Mr. Weare wrote alfo to the delegates of that ftate in Congre $\int s,+$ urging them to take advice, and procure the interpofition of Congrefs ; intimating his apprehenfions, that this would be the only method, in which the controverly could be fettled, without the effufion of blood, as all attempts for reconciliation had been in vain.

Nor were the governor and council of Vermont without their difficulties, in the management of thefe affairs. To guide the movements of a people, irritated by a long feries of injuries, and now too much elated by fuccefs, was a critical and difficult bufinels. Aware of the applications that would be made to Congre $\varsigma_{2}$ 


\section{THE NATURAL AND CIVIL}

Congrefs, in September they fent Col. Ethan Allen, as their adrocate to that body ; and to procure in: formation, in what light their proceedings were view ed at Philadelphia. Upon his return he made report, ${ }^{*}$ that Congrefs was unanimoufly oppoled, to their forming any connexions with the people of Newhampthire: And that if thole proceedings were difannulled, none of the members of Congrefs, ex cept the delegates from Newyorl;, would oppofe their independence.

The next affembly of Vermont met in Odtover, at Windfor. Reprefentatives from ten of the $f_{1 x}$ teen towns, took their feats in the affembly. A queftion was moved, "Whether the towns on the eaft fide of Connecticut river, which had been admitted into an union with Vermont, fhould be ereeted into a county by themfelves? The vote paffed in the negative. Finding by this, and fome other votes, that the affembly declined to do any thing more, to extend their jurifaiction to the eaft of Connecticut river, the members from thofe towns withdrew from the affembly, and were followed by fif teen of the reprefentatives from fome of the towns in Vermont, adjoining to the river, with the depuiy governor, and two affittants. The affembly of Vermont confifted of but fixty members, two thirds of which were neceffary to make a houfe, to do bufinefs: And this, was juft the number that was left, when the feceding members had withdrawn. The remaining members went on with the public bufr. nef, and continued their feffion, until the bufinefs of it was finifhed: But he referred the matter to their conftituents, to inftrut them how to proceed with regard to the union with Newhampfhire, at thei: next feffion. + - The members who had withdrawn themfelves

* October 10.

+ Allen's Vindication, p. 14. 16:22, 44. 
themfelves from the affembly, formed into a convention, and gave an invitation to the towns on both fides of Connecticut river, to unite, and to meet with them, in a convention at Cornifh, in Newhampfhire, Dec. 9, 1778. - The interefts and views which produced thefe proceedings, were pretty well underftood, and proved greatly injurious to Vermont. The peo. ple on both fides of Connecticut river, withed to form a government, the center and feat of which, fhould be upon the river. The people on the weft fide of the mountains, were aver?e to this plan, and to any connexion with Newhampfhire.

On December the gth, the convention which had been called, met at Cornifh, one of the fixteen towns. They agreed to unite, without any regard to the limits which had been affigued to Newhampthire, in ${ }_{17} 6_{4}$; and to make the following propofals to that government. Either to agree with them on a di. vifional line, or to fubmit the difpute to Congrefs, or to arbitrators mutually chofen. If neither of thefe propolals flould be accepted, arid they could agree with Newhampthire upon a plan of government, they refolved further, "We will confent that the whole of the grants connect with Newhamplhire, and become with them one entire ftate, as it was limited and bounded, before the fettling of the faid line in 1764 ." Until one of thefe propofals fhould be complied with, they refolved to truft in providence, and defend themfelves. *-There were but eight towns from Vermont, which were reprefented in this convention; and fome of them declined to act in making any overtures to Newhampthire, to extend their jurifdiction over the ftate of Vermont. But the proceedings of the convention, ferved to difcover to the whole body of the people, what had been the views of the leading men, in propofing the union of

* Allen's Vindication, P. 32,33 . 
of the Gxteen towns from Newhamplhire: It was now manifent, that their whole aim, had been to form a government, the center and feat of which, thould be upon Connecticut river. This would be affected, either by connecting a confiderable part of Newhamplhire, with Vermont ; or by breaking up the government of Vermont, and connecting the whole of it, with Newhamplhire: The one or the other of thele meafures, they were earneft to effeet; and either of them would probably have formed a ftate, the metropolis of which, mult have been upon the river which divides the two ftates. - To get rid of a connexion, which had occafroned fo much trouble and danger, the affembly of Vermont, on Feb. 12, 1779, voted to diffolve the union, which had fubfilted between them, and the towns in Newhamplhire; and iminediately communicated their refolves to that government.* Encouraged by thefe divifions, the affembly of Newhamplhire was perfuaded by fome of her leading members, to claim the whole tract of country, which belonged to her before the royal determination in $176_{4}$ : Accordingly that ftate put into Congrefs, a claim to the whole territory of Vermont. Newyork took the fame ftep, and put in her claim to the whole of the lands. As Newhampthire had not the leaft pretence, upon any principle whatever, to make fuch a claim it was not doubted in Vermont, but that intrigues had been formed by the leading men in thofe two ftates, to divide Vermont between them. The range of mountains, which runs through the ftate, would afford a natura! line, for fuch a divifion: And this meafure would unite the two ftates of Newhampthire and Newyork; and put an end to all future controverfy, with the people of Vermont; either refpecting their limits, the validity of their grants, or the powers of government which

* 1779, June 24. 
which they had affumed. And if thefe two flates could be united, there was a fair profpect that the reft would leave them to fettle the affairs of Vermont, which began to bear a very ferious afpect, and might prove troublefome to Congrels. - The other ftateshad not as yet concerned themfelves, about thefe controverfies; but Maffachufetts now interpofed. Whether aiming to difappoint the views of Newhampthire and Newyork, or in earneft to fecure a part of the controverted lands, that fate alfo put in a claim to a large part of Vermont : And her claim had a much better appearance, than that of Newhamplhire: For although the line between Maffa. chufetts and Newhamphire might be efteemed to be fettled, yet the line between Maffachufetts and NNew york had never been determined.

While thefe controverfies had been carried on with Newhampthire, the debate with Newyork had not at all fubfided. In a letter of July 7 th, 1778 , Mr. Clinton, governor of Newyork, wrote to one of his friends in Vermont, that he "would ftill as on a former occafion, earneftly recommend a firm and prudent refiftance to the draughting of men, raifing taxes, and the exercile of every act of government, under the ideal Vermont ftate; and in fuch towns, where our friends are fufficiently powerful for the purpofe, 1 would advife the entering into affociation, for the mutual defence of their perfons and eftates again? this ufurpation." "In a letter of July 8th, he warmly urged Congrefs to come to fome decifion on their controverfy with Vermont; blamed the inhabitants for the violence of their proceedings, affirmed that it would foon bring on a civil war, and that all the grievances of the people of Vermont had fuffered, arofe from the former government of Newyork, and not from the prefert.

In

* Copy of a letter from governor Clinton, to Pelatiah Fitct, Eig:

+ Aitelted copy. 


\section{THE NATURALAND CIVIL}

In 1779 , the controverfy with Newyork bore a more hoftile appearance. There were feveral perfons in the fouthealt part of the ftatc, then called the county of Cumberland by Newyork, who were attached to the authority of that fate, and oppcled the government of Vermont. To fome of them, gov ernor Clinton had given cominifions. They afferted that they had a regiment, of about five hundred men; and that a committee of the county, was alfo oppofed to the authority of Vermont. The government of Vermont found it neceffary, to put an end to thefe hoftile affociations; and Col. Etban Allen was directed to raife a part of the militia, for that purpofe. Upon this intelligence, a Colonel bearing 2. commiffion under the government of Newyork, wrote to governor Clinton for his advice and direction, fuggefting the neceffity of having the militia of Albany held in readinefs to attack any armed force, that fhould gather with that defign; and that it would be an ealy thing to get intelligence, by employing the enemies of Vermont, in their own towns, to give information.* In anfwer to this application, the governor of Newyork recommended in general, firmnefs, and prudence, and in no inftance to acknowledge the authority of Vermont, unlefs where there was no alternative left between fubmiffion and inevitable ruin: He alfured them, at the fane time, that if any attempt was made by Vermont to reduce the:n by force of arms, he would inftantly iffue his orders to the militia, who were properly equipped, and who would be led againft the enemies of the ftate, whereever they might bappen to be.t

Alanned with thefe profpeds, Mr. Clinton wrote to the prefident of Congrefs, May the $18 \mathrm{th}$, that matters

*.Patterfon's letter to Covernor Clinton, of May 5, 1779; and Mit ot's retition of Mav $4,1779$.

t.Clintou's letter to.S. Mino:, of May, 11, $17 / 9$. 
thatters were faft approaching to a very ferious crifis, which nothing but the inmediate interpofition: of Congrefs, could poffibly prevent; that he daily expected he fhould be obliged to order out a force, for the defence of thofe who adhered to Newyork; that the wifdom of Congrefs would fuggen to them, what would be the conlequence of fubmitting the controverfy, efpecially at that juncture, to the decifion of the fword; but that juftice, the faith of government, the peace and fafety of fociety, would not permit them, to continue any longer paffive fpectators of the violence committed on their fellow citizens.* Thefe letters, and fundry other papers relating to the difputes with Newhamplaire, were iaid before Congre $\int_{s}$, May 29th, 1779, and were referred to a committee of the whole. On June 1 ft, Cons grefs refolved, "that a committee be appointed to repair to the inhabitants of a certain diftrict, known by the name of the Newhamplaire grants, and inquire into the reafons why they refufe to continue citizens of the refpective fates, which heretofore exercifed jurifdiction over the faid difrict. And that they take every prudent meafure to promote an anicable fettlement of all differences, and prevent divifions and animofities, fo prejudicial to the United States." +

While the governor of Newyork was taking the fe meafures with the party that adhered to him in Vertnont, and with Congrefs, Allen marched with an armet force, and made prifoners of the Colonel, and militia officers, who were acting under the authority of Newyork. Complaint was inmeriately made to governor Clinton, with an earneft requen, that he would take the moft fpeedy and effectual meafures for their relief. $\mathrm{On} J$ une the $q \mathrm{~h}, \mathrm{Mr}$. $\mathrm{H} \mathrm{h}$

* Clinton's letter to Congrefs, of May 18, 1779 .

Clinkn

1. Journal of Congrefs, June 1, $177.9, p^{2} 237$.

+ S. Minot's letter to governor Cinion, of Miay $25,17,9$. 
Clintor wrote again to Congrefs, informing ther what had happened, difapproving of their meafures, and particularly of the appointment of a committee to confer with the inhabitants; and wifhing their journey might be poftponed, until the legiflatuse of Newyork hould be convened, and take the refolu? tions of Congrefs under confideration. On the $16 \mathrm{th}$, Congrefis refolved that the officers who had been thus reftrained of their liberty, ought to be imme. diately liberated; and that their committee who were appointed to confer with the inhabitants fhould be directed to make inquiry into the matters and things contained in governor Clinton's letters ; and that all further proceedings be poftponed, until they fhould report.*

Five commiflioners were appointed to repair to Vermont : Of thefe but two, Dr. Witherfpoon, and Mr. Atle, attended. Thefe gentlemen repaired to Bennirgton, in June; made many inquiries, and had feveral conferences with the friends of Vermont, and with others who were in the intereft of Newyork. They propofed feveral queftions to the governor of Vermont, to which he returned written anfwers. Their aim feems to have been, to bring about a reconciliation between the parties. Upon their return they made a report to Congrefs, july $13^{\text {th }}$; but which evidently denoted, that no part of the bufinefs on which they were fent, had been effected.t

Four different claims were now before Congrels, to the fame tract of country ; and the controverfy had become fo intricate, and warm, that very ferious confequences were juftly to be feared. It became neceffary for Congrefs to interpole; and as all parties

* Journal of Congrefs, June 16, 1779, p. $259,260$.

+ Account of the proceedings of Mr. Witherfpoon, and Mr. Atle. 
res had appealed to that body, they could no longer. avoid coming to fome refolutions upon a matter, which feemed effentially to concern the union of the Itates. Accordingly on September 24, 1779, Congrefs, among other refolves, paffed the following : "Refolved unanimoufly, That it be, and hereby is moft earneftly recommended, to the ftates of Newhamphire, Maffachufetts Bay, and Newyork, forthwith to pafs laws, exprefsly authorifing Congrefs, to hear and determine all differences between them, relative to their refpective boundaries.-Refolved unanimoufly, That.Congrefs will on the firt day of February next, proceed without delay, to hear and examine into the difputes and differences relative to jurifdiction aforefaid, between the faid three Itates refpectively, or fuch of them as fhall pals the laws beforementioned on the one part, and the people of the diftrict aforefaid, who claim to be a feparate juvifdiction on the other, and after a full and fair hearing, will decide and determine the fame according to equity.-Refolved unanimoufly, That it is the duty of the people of the diftrict aforefaid, who deny the jurifdiction of all the aforenamed ftates, to abfain in the mean time, from exercifing any power over any of the inhabitants of the faid diftrict, who profefs themfelves to be citizens of, or to owe allegiance to any or either of the faid ftates, but that none of the towns, either on the eaft or weft fide of Connecticut river, be confidered as included within the faid. diftrikt, but fuch as have hitherto actually joined in denying the jurifdiction of either of faid ftates, and have affumed a feparate jurifdiction, which they call the ftate of Vermont. - And further, That in the opinion of Congrefs, the faid three ftates aforenamed, ought in the mean time to fufpend executing their laws over any of the inhabitants of faid diftrict, except fuch of them, as thall profers allegiance to, and confefs the jurifdiction of the fame refpectively.-

Refolved 
Refolved unanimouny, That in the opinion of Cans. grefs, no unappropriated lands or eftates, which are or may be adjudged forfeited or confifcated, lying in faid diftrict, ought until the final decifion of Congrefs in the premifes, to be granted or fold."**

From thefe refolutions it was apparent, that the views of Congrefs were to evade any determination, and to pacify and quiet all parties for the preferst and that it was of much more importance, in their view, to preferve the union and affection of the free ftates, than that of Vermont. At a time when the fate of America depended upon preferving the union of the ftates, and all might have been loft by the difaffection of any one, perhaps this evafive policy was the beit. It fecmis to have quieted all parties but Vermont. The ftates of Newhamplbire, and Newyork, paffed the acts which Congrefs had called for. Maffachufetts did not, and probably with a view to prevent the diftrict of Vermont from being facrificed by either, or both of the other ftates.

It was impoffible that Vermont fhould comply with the refolves of Congrels. To have four feparate jurifdictions exilling at the fame time, in the fame territory, as the refolutions recommended, would at any time have been ablurd and impoffible : leaft of all was it to be admitted or attempted, after the people had declared themfelves to be a free and jindependent ftate, affumed the powers of government, and excrcifed them in all cales, and in every part of the ftate. They had already formed their conftitution, enacted a code of laws, erected courts of jultice, and fully exercifed all the powers of government. The plan of four feparate jurifdictions, which Congrefs propofed, was incompatible with any fate of fociety; and the more dangerous, as Newyork was conftantly aiming to break up the government

* Journal of Congrefs, September 24, 1779 . 
government of Vermont, by granting commiffions to her adherents, cncouraging informers, and promoting difaffected perforis, in every part of the territo: ry; and at the fame time, denied their titles to their lands, and all the public acts of the ftate.

Nothing remained for Vermont in this fituation, but to take a decifive part ; and fupport with firmnefs and refolution, the independence which her reprefentatives had declared, by the defire of the people. Her rulers did not prove deficient in refolution: Well acquainted with their own rights and interefts, they determined not to facrifice them, either to the intrigues of the adjacent ftates, or to the policy of Congrels. The governor and council publifhed an appeal to the candid and impartial world,* in whicli they declare that " they could not view themfelves as holden either in the fight of God or man, to fubmit to the execution of a plan, which they had reafon to believe was commenced by neighbouring itates: That the liberties and privileges of the fate of Vermont, by laid refolutions, are to be fufpended upon the arbitrament and final determination of Congrefs, when in their opinion they were things too facred ever to be arbitrated upon at all ; and what they were bound to defend, at every rifk: That the Congrefs of the United States had no right to intermeddle in the internal police, and government of Vermont: That the fate exifted independent of any of the thirteen United States, and was not accountable to them, or to their reprefentatives, for liberty, the gift of the beneficent Creator: That the ftate of Vermont was not reprefented in Congrefs, and could not fubmit to refolutions paffed without their confent, or even knowledge, and which put every thing that was valuable to

* Drawn up by Stephen R, Bradley, Efq; publimed Dee. 19, 1779 
to them, at ftake: That there appeared a manifent inequality, not to fay predetermination, that Congrels thould requent of their conftituents power to judgre and determine in the caufe, and never afk the confent of thoufands, whofe all was at fake : They. alfo declared that they were, and ever had been ready to bear their proportion of the burden and expenfe of the war with Greatbritain, from its firft commencement, whenever they were admitted into the union with the other Aates: But they were not fo lont to all Senfe, and honour, that after four years war with Britain, in which they had expended fo much blood and treafure, that they thould now give up, every thing worth fighting for, the right of making their own laws, and choofing their own form of government, to the arbitrament and determination of any man, or body of men, under heaven."

- It feems to have been the defire and expectation of all parties, that Congrefs fhould take up the matter, as they had propofed, on February 1, 1780. Vermont had now acquired fuch numbers, popularity, and power, that much was to be expected from having her claims thoroughly underfood, and confidered by the United States. But inftead of being decided, the matter was not taken up at all, on the ift of Fcbruary : and on March $21 \mathrm{lt}$, it was order. ed by Congrefs that the matter be poftponed, nine fater, exclufire of thofe who were parties in the queftion, not being reprefented.* On June $2 d$, Congrefs refolved that the proceedings of the people of the Newhampthite grants were highly unwarrantablc, and Subverfive of the peace and welfare of the United States; and that they be Arictly required to foblear from any acts of authority civil or military, over thofe of the people, who profeffed allegiance to other 
other ftates: And on June the 9 th, they refolved to defer the matter to the fecond Tuefday in Sep: tember. *-Upon the receipt of thefe refolves, the governor of Vermont, by the advice of his council, replied, that "however Congreis might view thofe refolutions, they were confidered by the people of Vermont, as being in their nature fubverfive of the natural right which they had to liberty and independence, as well as incompatible with the principles on which Congrefs grounded their own right to independence, and had a natural and direct tendency to endanger the liberties of America; that Vermont being a free and independent ftate, had denied the authority of Congrefs to judge of their jurifdiction; that as they were not included in the thirteen United States, if neceffitated to it, they were at lib-: erty to offer or accept terms of ceffation of holtilities with Greatbritain, without the approbation of any othe: man, or body of men; for, on provifo that neither Congrefs, nor the legiflatures of thofe ftates which they reprefent, will fupport Vermont in her independence, but devote her to the ufurped government of any other power, the had not the moft diftant motive to continue hoftilities with Greatbritain, and maintain an important frontier, for the benefit of the United States, and for no other reward than the ungrateful one, of being enflaved by them; but notwithftanding the ufurpations and injuftice of neighbouring governments towards Vermont, and the late refolutions of Congrefs, from a principle of virtue, and clofe attachment to the cxufe of liberty, as well as from a thorough examination of their own policy, they were induced once more to offer union with the United States of America, of which Congrefs were the legal reprefentative body." $\dagger$

In

* Journal of Congrefs, March 21, 1780, p. 81, 82.84.

+ Gov, Chittenden's letter to Congrefs, of July $25^{\text {th, }} 1780$. 
In September, thcre feerns to have been a more ferious attempt, to bring the conteft to forne decifron. The claims of Newhampinite, and Newyork, were put in; and both thefe ftates pleaded that Vermont had no right to independence, but belong. ed to them. The agents of Vermont were alfo prefent, ${ }^{*}$ but were not confidered or treated by Congrefs, as the agents or reprefentatives of any ftate, or of a people invefted with legiflative authority. They announced their bufinefs to Congrefs, and requefted that when any debates came before Congrels, which might affect the rights, the fovereignty, or independence of the fate of Vermont, they might be admitted to be prefent. On September 19 th, they received a notification to attend Congrefs that day, on the hearing of the queftion refpecting the jurifs. diction of the Newhamplhire grants. On that day, and the next, the agents from Newyork exhibited their evidence to fhow that the people on the Newhampthire grants, belonged to them, and had no right to a feparate and independent jurifdiction. The queftion refpecting the right to jurifdiction, Vermont had always refufed to fubmit to the determination of Congrefs : And the agents were alarmed, to find by the.mode of proceeding, that Congrefs was admitting evidence to deride this queftion, without admitting Vermont as one of the parties; or confidering her agents in any other characler, than that of private perfons. They effeemed it their duty, to proteft againft the whole prosecding; and on September 22d, they put in a remonfrance to Congrefs : They declare they can no longer fit as idle fpectuters, without betraying the truft repofed in them, and doing violence to their own feelings; that by the mode of trial which was aropted, the fite of Vermont could have no hearing, without

$$
\text { denying }
$$

* The Ioncutable Ira Allen and Stephen R. Eradisy. 
denying their own exiftence, and that they would not take on themfelves that humility and felfabafement, as to lofe their political life in order to find it ; they declared their readinefs to bear a full proportion in all the expenfes of the American war, until it hould be ended, and their willingnefs that one or more of the leginatures of the independent ftates, fhould interpofe as mediators, and fettle the difpute; but reprobate every idea of Congrels fitting, as a court of judicature, to determine the difpute by virtue of authority given them, by the act or acts of the ftate or ftates, which made but one party ; they conclude with obferving, that if the matter is thus purfued, they ftand ready to appeal to God and the world, who muft be accountable for the awful confequences that may enfue.*-Having heard the evidence on the part of Newhamplhire, on September 27 th, Congrefs refolved that the further confideration of the fubject fhould be portponed. $t$

At no time had the fpirit of parties run higher, than at this period. During the whole of this trial, it does not appear that either of the contending parties, had any ideas of conciliatory meafures; all feem to have been determined to effect their purpofes: And although Vermont was not admitted to appear as one of the parties before Congrefs, her expectations and profpeets, had at no time been fo high. She well underftood the ground, on which the ftocd; and it was generally believed in the other ftates, tha: fome of her leading men would incline to join with Canada, and make the beft terms they could with the Britin government, if no alternative was held out to them, but fubmifison to the government of NewI i york.

* Remonftrance of Ira Allen and Stephen R. Bradley to Congrefs, September 22, 1780.

+ Journal of Congress, September 12. 19, 20. 27, 1780, p. $18 \%-: 97$. 
york. In this flate of the parties it was as dangerous to the American caufe, to decide againf Vermont, as againft Newhampfhire, or Newyork. Congrefs felt, and wifely endeavoured to avoid the difficulty: A queftion was made, whcther Congrefs had any power to form a new ftate, within the lim. its of the union.- Thofe who remember the viru. lence of thefe parties, and the precarious, fituation of the American contefl at that time, will not wonder that Congrefs found reafons, to avoid coming to any decifion at that period ; for no decifion could have been made, that would not have proved highly irritating to fome of thofe ftates, already too much in hamed, by the violence, and duration of the controverfy.

Difappointed in her expectations of admifron into the federal union, and alarmed by the meafures that were purfued by Newhampinire and Newyork, Vermont now endeavoured to increale her own internal ftrength, by purfuing the fame meafures, that had been adopted by thofe ftates, of claiming jurifdiction.-Moft of the inhabitants of the towns in the weftern parts of Newhamplhire, were defirous of being êfnexed to the government of Vermont : There were others, who wifhed to fupport the Newrhampinire claim, and aimed to extend her jurifdic. tion over the whole of Vermont. A convention was propofed, and letters were fent by feveral influential men in the intereft of Newhampfinire, inviting the weflern towns to fend reprefentatives, to attend a convention at Charleftown. Théc onvention washeld January $16 \mathrm{th}, 1781$; and confifted of reprefentatives trom forty three towns. To the dilappointment of thofe- who had propofed the meafure, a large majority of the convention, appeared to be in favour of joining with the government of Vermont. A committee was appointed to confer with her affembly, on that fubject: And on February 1oth, the commatstee 
mittee informed the affembly, then fitting at Windfor, that "the convention of the Newhamplhire towns, was defirous of being united with Vermont, in one feparate independent government, upon fuch principles as thould be mutually thought the moft equitable and beneficial to the whole." In confequence of this application, the legiflature refolved, on February 14th, that " in order to quiet the prefent difturbances on the two fides of the river (Connecticut) and the better to enable the inhabitants on the two fades of faid river to defend their frontier, the legiflature of this ftate, do lay a jurifdicional claim to all the lands whatever, eaft of Connecticut river, north of the Maflachufetts, weft of the Mafon line, and fouth of latitude $45^{\circ}$; and that they do not exercile jurifdiction for the time being." The convention of the Newhamplaire towns, was then. fitting at Cornith, on the oppofite fide of the river ; and on February $22 \mathrm{~d}$, the articles of union were agreed upon, and confirmed; and the affermbly of Vermont refolved, that they fhould be held facred.*

A petition had allo been received from a number of the inhabitants in the adjacent parts of Newyork, praying that Vermont would afford them protection againft the enemy in Canada, and receive them into union with her, that their forces might be mutually joined for the defence of the frontiers; informing at the fame time, that if their petition was rejected, they muft remove with their families and effects, into the interiour parts of the country for fafety. This petition of the inhabitants, the neceffity of defending the frontiers, and the meafures Newyork were purfuing to fubdue Vermont, were affigned as reafons by the legiflature, why Vermont ought to receive thofe inhabitants, into her union : Accordingly on Feb. $14^{\text {th }}$, it was refolved, "that the legiflature

- Journal of the aIfembly of Vermont, Vol, I. p. $356_{0}$ 
ture of this ftate, do lay a jurifdictional claim, to all the land fituate north of the north line of the ftate of Maffachuletts, and extending the fame to Hudfon's river ; the eant of the center of the decpent channel of faid river, to the head thereof; fiom thence eaft of a north line, being extended to latitude $45^{\circ}$; and fouth of the fame line, including all the lands and waters to the place where this ftate now exercile jurifdiction.-And not to exercife jurildic. tion for the time being."

Thus, while Newhampfhire and Newyork were extending their claims over the whole territory of Vermont, Vermont adopted the fame policy ; and in conformity to the petition of the inhabitants, extended her claim over a large part of the territory of both thefe ftates.

Great fuccefs attended this policy: Not only the fixtcen towns in Newhamplhire which had formerIy joined, but thofe in Vermont which had been difaffected upon the diffolution of the former union, and thole that had been attached to Newyork, im. mediately joined in the meafure. Moft of the towns in the adjacent counties of Cherhire, and Grafton, in Newharnpinire, declared for the union: And at a feffion of the affembly of Vermont in April, thirty five towns in the weftern parts of Newhamplhire, were reprefented. - The adjacent fettlements in Newyork generally cmbraced the fame meafures, and feveral petitions were received from their inhabitants at this feffion of the affembly, requefting the legillature of Vermont, to exercife jurifdiction over them without any further delay. A committee was appointed by the affembly, to confer with a convention of thofe diftricts; and on May ${ }^{1} 5^{\text {th }}$, articles of union were agreed to, by the reprefentatives of twelve difricts in Newyork, and the committee from Vermont. * Journal of the affembly of Vermont, Vol. I, Feb, 14, 178 s! 
Vermont. On the 16 th of June, thefe articles were confirmed by the legillature, and reprefentatives from ten of the difricts took their feats in the affembly of Vermont.*

Many circumftances had combined, to produce this union of the people, in favour of Vermont; and one of a fingular nature, had ferved to reconcile thofe, who had been unfriendly to the caufe of America; it was generally believed that negociations, were at this period, carried on between fome of the leading men in Vermont, and the Britifh generals in Cana$\mathrm{da}$, and Newyork. This report ferved to engage the adherents to Britifh government, to efpoufe the meafures of the new ftate: And fuch was the increafe of numbers, popularity, and power, which Vermont had now acquired, that the had in fact nothing to fear from the power, or from the policy of her oppofers: And notwithnanding the refolves of Congrefs, the affembly proceeded to make grants of their lands, without paying any regard to the grants which had been made by Newyork; thofe only excepted, which had been made in confirmation of the former grants from Newhampthire.

From thefe contefts refpecting Vermont, the Britin generals and minifters conceived high expectations, that they fhould be able to derive great ad. vantages. Unacquainted with the feelings, the views, or the fpirit of a people, contending for freedom, they calculated upon the fyftem of corruption; and had no doubt but they thould find a people in Vermont, that they could feduce from their attachment to the American caufe, and unite to the Britifh government. With this view they entered upon mealures, to perfuade Vermont to become a Britifh province.

\section{The}

- Journal of the affembly of Vermont, Vol, I. June $16,17810^{\circ}$ 
The wifh and aim of the Britifh general in Newyork, was firft announced in a letter from Col. Bev. Robinfon, to Ethan Allen, at that time a Colonel in the $\Lambda$ merican fervice. The letter was dated Newyork, Narch, 30 th, 1780 ; and delivered to Allen in the ftreet at Arlington, in July, by a Brition foldier in the habit of an American farmer. In this letter Robinfon began the bufinefs, thus, "I am now undertaking a talk, which I hope you will receive with the fame good intention, that inclines me to make it. $\$$ have often been informed that you, and molt onf the inhabitants of Vermont, are oppofed to the wild and chimerical fcheme of the Americans, in attempt. ing to feparate this continent from Greatbritain, and to cftablifh an independent tate of their own; and that you would willingly affit in uniting America again to Greatbritain, and reftoring that happy confitution we have fo wantonly and unadvifedly de. ftroyed. If I have been rightly informed, and thefe frould be your fentiments and inclination, $I$ beg you will communicate to me, without referve, whatever propofals you would wifh to make to the commander in chief; and I hereby promife that I will faith. fully lay them before him, according to your direccions, and flatter myfelf, I can do it to as good effect as any perfon whatever. I can make no propofals ro you, until I know your fentiments, but think upon your taking an active part, and embodying the inhabitants of Vermont in favour of the crown of England, to at as the commander in chief fhall direct, that you may. obtain a feparate government, under the king and contitution of England, and the snen, formed into regiments under fuch officers as you thall recommend, be on the fame footing as all the provincial corps are. - If you thould think proper to fend a friend of your own, here, with propofals to the general, he finall be protected, and well treated here, and allowed to return whenever he pleal. es.:- 
es." *-On the receipt of this letter, Allen immediately communicated it to the governor, and a number of the principal gentlemen in Vermont; who agreed in opinion, that it was moft prudent not to return any anlwer, but to let the matter pals into. oblivion.

On Feb. 2d, 1781, Robinfon wrote another letter to Allen, including a copy of the former, which he fuppoled had been mifcarried, as he had not received any anfwer. In this he writes, "The frequent accounts we have had for three months paft, from your part of the country, confirms me in the opinion I had of your inclination to join the king's caufe, and to affift in reftoring America, to her former peaceable and happy conftitution. This induces me to make another trial, in fending this to you; efpecially as I can now write with more authority, and affure you, that you may obtain the terms mentioned in the' above letter, provided you, and the people of Vermont take a decifive and active pars with us." $+-\mathrm{He}$ requefts an anfwer, and that forne method might be pointed out, for carrying on a correfpondence for the future; and information, in what manner the people of Vermont could be the mof ferviceable to the Britifh government, " either by a $\varepsilon$ ing with the northern army, or to meet and join an army from Newyork."

Allen returned no anfwer to either of thefe letters, but on March 9 th, 1781 , inclofed them in a letter to Congrefs, informing them of all the circumftances which had attended the bufinefs. In his letter to that body, he made feveral obfervations, juftifying the conduct of Vermont, afferiing her right to independence, and expreffing his determinate refolution, to do every thing in his power to eftablifh it. Confcious

* Copy of Robinfon's letter, by E. Allen.

+ Copy of Robinfon's letter of Feb, 2, 1781, by E. Allen. 
fcious of his own integrity, and fenfible that his ac. tivity and fufferings in the caufe of his country, were known to a!l America, he wrote in this Ityle; "I am confident that Congrefs will not dilpute my fin. cere attachment to the caufe of my country, though I do not hefitate to fay, I am fully grounded in opinion, that Vermont has an indubitable right to agree on terms of a ceffation of hoftilities with Greatbritain, provided the United States perfit in rejecting her application for a union with them: For Vermont, of all people would be the moft miferable, were the obliged to defend the independence of the United claiming States, and they, at the fame time, at full liberty to overturn, and ruin the independence of Vermont. I am perfuaded, when Congrefs confider the circumftances of this ftate, they will be more furprized that I have tranfinitted them the inclofed letters, than that I have kept them in cuftody fo Iong; for I am as refolutely determined to defend the independence of Vermont, as Congrefs are, that of the United States; and rather than fail, will retire with hardy Green Mountain Boys, into the defolate caverns of the mountains, and wage war with human nature at large."*

An event took place in the fpring of the year 1780 , which furnithed the Britifh with an opportunity, to make a fimilar attempt from Canadd. A number of men had been made prifoners in a defcent, which the Britifit made upon Rnyalton, in the month of May. Their friends applied to governor Cbittenden to fencl a fl $+\mathrm{g}$ into Canadd, to negociate thcir releafe, or exchange. The governor complied with their requett, and in the month of Ju!y, a flag was lent with a lctter to the commandine officer in Canada: In the fall, the Britifn came up Lake Champlain, in great furce: The commanding officer brought a very favourable

"E. Allen's letter to the piefiuent of Congrefs, March gth, 178 t. 
fuvourable anfwer from general Haldimand, to Gov ernor Chittenden's letter; and fent a flag to Ethan Allen, then a brigadiergeneral, and commanding officer in Vermont, propofing a ceffation of hotilities with Vermont, during a negociation for the ex. change of prifoners. Ailen agreed to the propofal, upon condition that it fhould extend to the adjacent frontiers of Newyork. The Britifh officer appeared to be unwilling to treat with any part of $A$ merica, but Vermont ; but finally agreed to every thing, which Allen propofed.

Before the enemy retired into their winter quar. ters, Colonel Ira Allen, and Major Joleph Fay, were appointed by the governor of Vermont, commifficners to negociate the propofed exchange of prifoners. They proceeded to treat with the Britifh agents, Captain J. Sherwood and George Smyth, on this fubject. The Britilh agents availed themfelves of this opportunity, to explain their views, to make their propofals, and to offer as complete an eftablifhment for Vermont, from the royal authority, as fhould be defired. The commiffioners from Vermont treated the propofals with affability, and good humour; and though they avoided bringing any thing to a decifion, the Britifh concluded, they were in a fair away to effect their purpofes; and the campaign ended, without any further holilitiss to Vermont.

The next year, the Britih entered upon the bufinefs, with high expectations of fuccefs; and it was the intereft of Vermont, not to undeceive thers. Newyork had withdrawn their troops, from the poft at Skeenfborough; all the continental tronps, bat been ordered out of the territory ; and the adjacen: ftates, did not afford them any affiftance. The people of Vermont were expoled to the whole force of the enemy in Canada, and had neither magazines, money, or an army, to oppole to the cnemy at the $\mathrm{K} k$ nothruid, 
northward, who were feven thoufand ftrong. No way of fafety remained for Vermont, but to endeavour to effect that by policy, which could not be done by power. The cabinet council concluded, that they were defignedly forfaken by the continent, to force them into a fubmiffon to Newyork ; and that it was clearly their duty, to provide for the fafety of the people, in the only way that remained, by managing the Britifh attenpts to corrupt them, to their own advantage.\%

On May 1ft, Colonel Ira Allen was fent to Canada, with a commifion to negociate the exchange of prifoners. The Britifh agents concluded, that the day of their complete fuccels, was at hand: They complied with every thing which Allen required; and urged inceffantly to have Vermont declare itfelf a Britifh province; with affurances, that every thing the could afk for fhould be granted by the Britilh generals, and confirmed by the king, in the moft ample manner. Colonel Allen was fully equal to the bufinefs, which had been entrufted to him; and both he, and his employers, were among the firmeft friends to the independence of Vermont, and of America. With a fingular talent at negociation, he fuffered the Britifh agents to deceive themfelves with an idea of their own luccels, and completely effected his own views, in leading the enemy into an agreement, that no hoftilities fitould be commenced againtt the ftate of Vermont.-In July, Major Jofeph Fay was fent to the cnemy on Lake Champlain, and completed an exchange of prifoners : And in September, Allen and way, had another conference with the Britifh agents; which like the former, left the Britifh in high expectations of making Vermont a Britifh province; and piocured to Vermont

* Governor Chittenden's letter to Ceneral Wa hington, of November 34 lb, $17^{3} l$. 
Vermont the folid advantages, that the enemy avoided all hoftilities againt her, and returned all her inhabitants, which had been taken prifoners.

On October $19 t h, 1781$, Lord Cornwallis furrendered with his army to General Wafhington. When the news of this important event arrived, the general affembly of Vermont were fitting at Charleftown. The enemy had come up the lake with a large force, and were then at Tyconderoga. They had concluded, that their bufinels was fo far effected with Vermont, that they might make an open proclamation of their defigns and offers. Their agents had accordingly brought with them, a number of printed proclamations, announcing the royal offers to the people of Vermont, and inviting them to unite, and become very happy, as a royal province, under the king's government. The Britifh agents fent on their letters to Charleftown, announcing the meafures they were purfuing, and propofing to publifh and difperfe their proclamations, immediately among the people. They were told in anfwer, that the news of Cornwallis's furrender, would render fuch a tep extremely dangerous, and was the fure way to prevent all profpect of fuccels; and that they mult wait, until time thould determine, what was practicable and prudent.-Mortified by the difafter of Cornwallis, but comforted with groundlefs expectations and hopes, they returned in a peaceable manner down the lake, and went into winter quarters, without having done any injury to Vermont, through the whole campaign.

In the winter of 1782 , the enemy in Canada, were extremely impatient to know, what effect the furrender of Cornwallis had produced on the minds of the people of Vermont. In February and in April, the Britifh agents wrote in the molt preffing terms, for information. Their anxiety and views will beft appear, from the ftyle of their letters : The following 
following extract, is from a letter from one of the Britilh agents, dated $281 \mathrm{~h}$ February 1782 , "My anxiety to hear from you, induced me to apply to his exrellency [Gencral Haldımand] for leave to fend the bearer, with this; which having obtained, 1 earneftly requeft you to fend me in the moft candid, unreferved manner, the prefent withes and intentions, of the peopie, and leading men of your ftate, refpecting our former negociations; and what effect the late cataftrophe of Lord Cornwallis, has on them.-Will it not be well to confider, the many chances and viciffitudes of war? However brilliant the laft campaign may appear, the next may wear a very different afpect: Add to this, the great probability of your being ruined, by your haughty neighbours, elated by (what they call) a fignal vic. tory ; and I hope you will fee as I do, that it is more than ever your intereft, to unite yourfelves with thole, who wifh to make you a happy and frce government. Will there be a proper time to fend the proclamations? I repeat my requeft, that you will tell me, without referve, what may be expected in future"

On the $22 \mathrm{~d}$ of $A$ pril, the Britih agents write in this ftyle, "In confidence, we take this opportunity to acquaint you, by the authority of his Excellency General Haldimand, that he is nill inclined to treat amicably with the people of Vermont; and thefe his generous and humane inclinations, are now feconded by much fronger powers from his Majefty, than he has hitherto enjoyed for that purpole. - We do in confidence; officially affure you, that every article propofed to y'ou in his excellency's former offer, as well as the confirmation of the eaft and weft unions, in their utmoft limits, will be amply and punctually complied with.- We hope, your anfwer may be fuch, as to unburden our anxious minds." Extremely fearful about the event, and impatient at 
not receiving an anfwer, on April 30 th, they wrote again, and carried their offers and promifes to aftill greater extent : "His excellency has never loft fight of his firt object; and I am happy to be able in this, to inform you, that the general has lately received by way of Halifax, full powers from the king to eflablifh $\mathrm{V} \longrightarrow \mathrm{t}$ government, including the full extent of the eaft and weft unions, with every privilege and immunity, formerly proffered to you ; and he is likewife fully authorized, as well as fincerely inclined, to provide amply for $* * * * *$, and to make $* * * * *$ brigadiergeneral in the line, $4_{*} * * * * * * * *$ field officers, with fuch other rewards, as your fincerity, and good fervices in bringing about the revolution, may in future merit. In hort, the general is vefted with full powers, to make fuch rcwards, as he fhall judge proper, to all thofe, who diftinguifh themfelves, in promoting the happy union: And as his excellency has the greateft confidence in you, and $* * * * *$, much will depend on your recommendations."

In July, Colonel Ira Allen was fent again into Canada, with a letter from the goyernor of Vermont, to General Haldimand, requenting the releafe of two officers, belonging to Vermont, who were then prifoners in Canada. The Britifh agents were uncommonly defirous, of bringing their negociations with Vermont, to an immediate decifion. All the arts of negociation were employed, on the one hand, to perfuade Vermont, to declare herfelf a Britifh province; and, on the other, to avoid this flep, without bringing on a renewal of honilities. A fecret treaty was offered, and much urged: And in the event, Haldimand agreed to continue the fufpenfion of hoftilities ; and wrote a very friendly letter to Governor Chittenden, fully complying with his requeft of liberating the prifoners, and announcing his pacific difpofition towards Vermont, in this unequivo. 
cal manner: "You may reft affured that I fhall give fuch orders, as will effectually prevent hoftili. ties of any kind, being exercifed in the diftrict of Vermont, until fuch time as a breach on your part, cr fome general event, may make the contrary my duty. And you have my authority, to promulgate, in luch rranner, as you thall think fit, this my intention to the pcople of the faid diffict, that they may, without any apprehenfion, continue to encourage and promote the lettlement and cultivation of that new country, to the intereft and happinels of them. felves, and their pofterity."*

Writh this year, the rvar, and the negociations, came to an end; leaving favourable impreflions on the government of Canada, towards Vermont. The Iaft letter the Britifh agents wrote upon the bufinefs, was on March $25^{\text {th }}, 1783$; before the news of the peace, was officially known, or fully believed in Canada. Their views and fentiments, at that period, were thus expreffed, "I am commanded to ac. quaint you, that actuated from the beginning, by a incere defire of lerving you, and your people, as well as of promoting the royal caule, by reuniting you with the mother country, his excellency never Jof an opportunity of reprefenting every circumftance that could be advanced in your favour, to the lring's minifters, in the hope of accomplifhing a reconciliation. - Ilis excellency will continue by fuch ieprefentations, to do all in his power, to ferve you, but what efrect it may have, at this late period, is very uncertain. Whilc his excellency fincerely regrets the happy moment, which it is much to be feared, cannot be recalled, of reftoring to you the bleffings of the Britifl government, and views with concern tiue fatal conlequences approaching, which he

* Haldimand's letter to Goveraor Chittenden, dated Que. bec, 8:h Augut, 1782 . 
he has fo long, and fo frequently predicted, from your procraftination, he derives fome fatisfaction from a confcioufnels of not having omitted a circumftance, which could tend to your perfuafion, and adoption of his defired purpofe. In the prefent uncertain ftate of affairs, uninformed as his excellency is, of what is doing, or perhaps done, in a general accommodation, he does not think fit, until the refult thall be known, to give any opinion, which may influence you, perhaps to the prejudice of your interefts, or that might interfere with the views of government. If the report now prevailing, has any foundation, a very fhort time will determine the fate of Vermont.-Should any thing favourable prefent, you may ftill depend on his excellency's utmoft endeavours, for your falvation."

Thus terminated a controverfy, which occafioned many and valious conjectures, at the time when it was carried on. On the part of the Britifh, it confifted of conftant attempts and endeavours to perfuade the leading men of Vermont, to renounce their allegiance to the ftates of America, and become a Britifh province. On the part of the gentlemen of Vermont, the correfpondence confifted of evafive, ambiguous, general anfwers and propofals ; calculated, not to deftroy the Britifh hopes of feduction, but carefully avoiding any cngagements or meafures, that could be conftrued to be an act of the government: And it had for its object, a ceffation of hoftilities, at a time when the ftate of Vermont, deferted by the continent, and unable to defend herfelf, lay at the mercy of the enemy in Canada.

Eight perfons only in Vermont, were in the fecret of this correfpondence. Each of them, were known to be among the moft confirmed friends, to the $A$. merican caufe. They had avowed their fentiments, and embraced the caufe of their country, from the beginning of the American war: They had fuffered feverely, 
feverely, often borne arms, and lone every thing its their power, to defend the independence of the ftates: And through the whole of this correfpondence, they gave the molt decifire proofs, that they could not be bought, or brided, by any offers of wealth or honour. - But fo odious were the Britifi proceedings and government, at that time, to the people of America, that it was with difficulty, the people of Vermont could be kept quiet, under the idea of a correfpondence carried on with the Britifh, though known to be defigned for their protection. Once or twice, there were fmall infurrections, to de. mand explanations : And nothing but the well known, and ftrong attachment of the gentlemen concerned, to the independence of Vermont and of $A$ merica, could have preferved them from open violence, and deffruction.

It may be doubted, how far fuch a meafure was juftifiable, in that, or in any other ftate of things. On the one hand, it may be faid, when the fafety of all America was in queftion, and in much danger, nothing ought to have been done to encourage the enemy, that they thould be able to divide, and thus fubdue the continent. On the other hand, it inay be urged, that when thirty thoufand people were deferted by the Congrefs, and become the objects of the intrigues and policy of the adjacent ftates, it was as juftifiable and neceffary for them, to provide for their lafety, as it was for the relt of the continent.If there was no other altermative for the people of $V$ Vermont, than to be divided, fubdued, and delivered over to the power of their ancient enemies; their leaders will not be blumed, for taking neceffary and adequate meafures, to prevent fuch an evil. In fuch a fruation, it was farcely poffible for the people of Vermont to belicve, that they could be under any moral obligation, to facrifice themfelves, to procure independence for thole, who by the aft of their reprefentatives, 
teprefentatives, had rejected them from theit confederation.

But whatever may be thought refpecting the propriety of fuch policy, the event hewed, that the gentlemen of Vermont had formed a found judgment, with regard to the effect. Flattered with the profpect, that they thould draw off a confiderable part of the continerit, to their government and meafures, the Bricifh carefully avoiced all hottilities againt Vermone, reftored her prifoners, forbade their troops to enter or attack her territory, and confidered the peo. ple rather in the light of friends, than enemies. Thus while the Britifh generals were fondly ${ }^{\circ}$ imagining that they were deceiving, corrupting, and feducing the people of Vermont, by their fuperiour arts, addrefs, and intrigues; the wifer policy of eight honeft farmers, in the moft uncultivated part of America, difarmed their rorthern troops, kept them quiet and inoffenfive during three campaigns, afinted in fubduing Cornwallis; protected the northern frontiers, and finally faved a ftate.

Not only the Britih generals, but fo much was the Britifh government deceived by thefe appeatances, that the minifters flatered themfelves, that they had riearly effected the defection of Vermont from she American caufe, and drawn them over to the Britioh intereft. Lord George Germain was at that time minifter of ftate, for the American department. A letter which he wrote to Sir Henry Clinton, commander of the Brituh troops in Newgork, was intercepted and carried into Philadelphia. The letter was dated Whitehall, February $7,178 \mathrm{I}$, in which he wrote thus, "The return of the people of Vermont to their allegiance, is an event of the urmoft importance to the king's affairs; and at this time if the French and Warhington really meditate an irruption into $C_{a n a d a}$ may be confidered as oppofing an unfurmountable bar to the attemot. General Hial. L. 1 dimand, 
dimand, who has the fame infructions with you to draw over thofe people, and give them fupport, will, I doubt not, pufh up a body of troops, to aet, in conjunction with them, to fecure all the avenues, through their country into Canada; and when the feafon admirs, take poffeflion of the upper parts of the Hudfon's and Connecticut rivers, and cut off the communication between Albany and the Mohawks country. How far they may be able to cxtend themfelves fouthward, or eaftward, muft depend on their numbers, and the difpofition of the inhabitants."

This letter was publifhed in the Pennfylvania Packet, of Aug. 4th, 1781. Nothing could have been better fuited to promote the interefts of Vermont, than the foyle, and publication of this letter. The people of the United States, had now complete evidence that the Britifh generals in Newyork and Canada, had orders to receive and fupport the people of Vermont, and that the Britih minifry were perfuaded of their difpofition to join the Britih gov. ernment. They faw at once, the effect this nuft have upon the American war; and they knew at the fame time, that nothing was wanting to prevent it, but to admit Vermorit into the union of the Rates. The public opinion was now decidedly in favour of this meafure: And it was found that the leaders of Vermont, were fully equal to the bufinels they had undertaken; and while they had acled with great fpirit and firmncls, in every part of the American war, they had dilcovered the fame activity and intrepidity, in every part of the conteft refpecting the independence of their own ftate. No policy, it was every where urged, could be more dangerous, than to hazard the fuccels of the American caufe, upon a difpute with a people, whofe exertions had fully Shown that they deferved all the bleffings of freedom, to as great an extent as any of their neighbours; and 
whofe ability and enterprife would not fail to fecure it, in one form or another. What gave weight to the public opinion, was the general belief that the commander of the American forces, was fully of the fame opinion.

The Congrefs of the Uniled States immediateiy took up the matter, and formed their refolves in a fyle very different from what they had done, the year before. Their refolves were officially tran[mitted to the legiflature of Vermont, and were in the following words: "By the United States in Congrels affembled, Auguft 7,1781 . Whereas the ftates of Newhamplhire and Newyork have fubmitted to Congrels, the decifion of the difputes between them, and the people inhabiting the Newhampthire grants, on the weft fide of Connecticut river, called the ftate of Vermont, concerning their refpective claims of juriddiction over the faid territory, and have been heard thereon; and whereas the peopls aforefaid claim and exercife the powers of a fovereign independent ftate, and have requefted to be admitted into the federal union of the United States in Ame. rica; in order thereto, and that they may have an opportunity to be heard in vindication of their faid claim; Refolved, That a committee of five be appointed to confer with fuch perfon or perfons, as may be appointed by the people refiding on the Newhampfire grants, on the weft fide of Connecticut river, or by their reprefentative body, relpecting their claim to be an independent ftate; and on what terms it may be proper to admit them into the federal union of thefe ftates, in cafe the United States in Congrefs affernbled thall determine to recognize their independence, and thereon to make report.-And it is hereby further recommended to the people of the territory aforefaid, or their reprefentative body, to appoint an agent, or agents to repair immediately to Philadelphia with full powers and inftructions to 
confer with the faid committee, on the matters aforefaid, and on behalf of the faid people to agree upon, and ratify terms and articles of union and confederation with the United States of America, in cale they thall be admitted into the union. And the faid committee are hereby inftructed to give notice to the agents of the flates of Newhampthire and Newyork, to be prefent at the conference aforefaid.

"Augutt 20, 1781.-Refolved, That it be an indifpenlable preliminary, to the recognition of the independence of the people, inhabiting the territory called Vermont, and their admiffion into the federal union, that they explicitly relinquifh all demands of lands, or jurifdiction, on the eaft fide of the weft bank of Connecticut river, and on the weft fide of a line beginning at the northweft comer of the ftate of Maffachufetts, thence running twenty miles eaft of Hudfon's river, fo far as faid river runs northeafterly in its general courfe, then by the weft bounds of the townthips granted by the late government of Newbampthire, to the river running from South bay to Lake Champlain, thence along the faid river ta Lake Champlain, thence along the waters of Lake Champlain to the latitude forty five degrees north, excepting a neck of land, between Miffilkoy bay, and the waters of Lake Champlain."**

With thefe refolves of Congrefs, a verbal meffage was fent by General Wahington to Governor Chit. tenden, defiring to know what were the real defigns, views, and intentions of the people of Vermont : Whether they would be fatisfied with the independence, propofed by Congrefs; or had it ferioufly in contemplation, to join with the enemy, and become a Britifh province. The governor returned an unequivocal, and decifive anfwer. That there were no people on the continent, more attached to the caufe of * Journal of Congrefs, Aug. 7 th, and 20th, 1781, p. 166. 170 . 
of America, than the people of Vermont; but that they were fully determined, not to be put under the government of Newyork, that they would oppole this by force of arms, and would join with the Britith in Canada, rather than to fubnit to that governinent.*

In October, the general affembly of Vermont, met at Charleftown in Newhamplhire. The refolutions of Congrefs were laid before them ; but although the refolves held out all that Vermont had at firft claimed, or had ever expected to obtain, they did not produce a full confidence in Congrefs; nor did they fall in with the views of thole towns, which had joined Vermont, from Newhamplhire, and Newyork. When they had been debated, the afrembly voted, October the $19^{t h}$, that they could not comply with the refolutions of Congrels, of Augult the 20th, without deftroging the foundation of the univerfal harmony and agreement, that fubfifted in the ftate, and a violation of folemn compact entered into by articles of union and confederation; that they would remain firm in the principles, on which the ftate had firft affumed government, and hold the articles of union, which connected each part of the ftate with the other, inviolate; that they would not fubmit the queftion of their independence, to the arbitrament of any power; but that they were willing and ready to refer the queftion of their jurifdictional boundary with Newhamplhire, and Newyork, to commiffioners mutually chofen; and when they fhould be admitted into the American union, they would fubmit any fuch difputes to Congrefs. $t$

The refolves of Congrefs, though they had not been accepted by Vermont, were confidered by Newyork,

* Governor Chittenden's letter to General Wafhington, of Nov. 14,1781 .

t Journal of Congrefs, April $4,1782, p \cdot 326-329$. 
york, as a virtual determination of her claims. The legillature of that ftate, on the $15^{\text {th }}$ and $19^{\text {th }}$, of November, paffed a number of refolutions, and a folemn proteft, againt the proceedings of Congrels. Having flated their claims, and related forne of the former proceedings of Congrefs relative to the controverfy, they refolved, that the legiflature of that State, was greatly alarmed at the evident intention of Congrefs, from political expedience, to eftablifh an erbitrary boundary, which excluded from that fate, a great part of its territory; that it was the fenfe of the legiflature, that Congrefs had not any authority, by the articles of confederation, to intermeddle with the former territorial extent of jurildiction or property, of either of the United States, except in cales of difpute between two or more of the flates in the union, nor to admit into the union, even any Britifh colony except Canada, without the cenfent of nine Rates, nor any other ftate whatfoever, nor above all to create a new ftate by difmembering one of the thirteen United Sates, without their univerfal confent ; that in cale of any attempt of Congrefs to carry into execution their acts of the $7^{\text {th }}$ and 20 th of Augun, the leginature were bound in duty to their conflituents, to declare the fame an affumption of power, and a manifert infraction of the articles of confederation, and do therefore folemnly proteft againf the fame; that a copy of their refolutions be tranfmitted to Congrefs, and their delegates expreffly direcled and required to enter their diffent on $\mathrm{cv}$ ery ftep, which may be taken in and towards carrying the faid acts of Congrefs into execution.*

Anxious for the fafety of Vermont, and wifhing to avail himfelf of every meafure to promote it, on Nov. 14th, Governor Chittenden wrote to General Wafhington, on the fubject, explaining to him their fituation,

* Journal of Congreís, April 4,1782, p. 329-334. 
fatuation, difficulties, and views. In this letter, the governor placed great confidence in the general, and gave him an sccount of the tranfactions with the enemy; and arigned the reafon, "Vermont drove to defperation, by the injuftice of thole who fhould have been her friends, was obliged to adopt policy in the room of power ;" and with regard to the laft. relolution of Congrefs, he afcribed them to their true caufe, not the influence of their friends, but the power of their enemies; "Lord George Germain's letter wrought on Congrefs, and procured that from them, which the public virtue of this people could not obtain."

While thefe tranfactioris were taking place, new fcenes of difficulty, and of danger, were opening in the eaftern and weftern unions. The fheriff of one of the counties of Newhamphire, which had joined with Vermont, wrote to Governor Chittenden, that there was a high probability, that the government of Newhamplhire were about taking coercive meafures, to compel the citizens who had joined with Vermont, to fubmit to the laws and authority of Newhamplnire. The governor, on December $14^{\text {th }}$, wrote to General Paine, at that time lieutenantgovernor of the ftate, to call on the militia eaft of the green mountains, and affift the theriff in the execution of the laws, and to defend the citizens againt any infult; and if Newhamphire fhould make an attack with an ármed force, to repel force by force. Mr. Paine fent a copy of the orders which he had received, to the prefident of Newhamplhire, and wrote that if Newhampfhire began hoftilities, he fhould execute the orders he had received, and did not doubt but that the people would fupport him, with their molt fpirited exertions, and that Newhamplhire muft be accountable for the confequences. Vith

* Mr. Pain's lester to Pieficent Weare, Dec, 23,2, 7 \&. 
With this letter, commifioners were fent to the general affembly of Newhamphire, to endeav. our to accomodate matters, and prevent the effufion of blood*.

At the fame time the troops of Newyork were in motion to fupprefs the proceedings of their citzens, who had formed an union with Vermont. On December $18 \mathrm{th}$, their commander, Brigadiergeneral Ganfevoort, wrote to the commanding officer of the troops from Vermont, that in purfuance of a law of Newyork, he had been detached with a part of his brigade to fupprefs an infurrection of fome of the inhabitants of Schaticook, and Hootac; that he was arrived to aid the Theriff of the county, to apprehend the infurgents; and was informed that a large body of troops from the grants, were marching in force, with artullery; but before he proceeded any further, he wifhed to be informed what was the object of their movement into the interiour parts of that ftate, and by what authority. + -Colonel Walbridge conmandant of the tronps from Vermont, wrote in anfwer, that the object of their movement, was to protect thofe of the inhabitanis, who in confequence of the union, profeffed allegiance to the ftate of Ver. mont ; that he wished conciliatory methods might be adopted, but if thore perfons who profeffed to be citizens of Vermont, fhould be imprifoned, and their property deftroyed, he was not to be anfwerable for the confequences. +

All parties feem to have been feriouny alarmed, at thefe srofpects of a civil war : And happily fo: chemielvcs, they had all of them, more inoderation and wiftom, than to proceed to hontilities. Reflect. ing on the war with Greatbritain, in which their country

* General Roger Enos, Ira Allen, and Wrilliam Page.

+1 . Cianferonrt's lettcr, of December 18,1731 .

* E. Walbidige 's icitcr, of December $13,178 \mathrm{I}$ 
country was fo deeply engaged, they feem to have been fully convinced that no differences among the ftates, ought to be fuffered to produce a war among themfelves.

A controverfy fo fuli of mifchief and danger to the United States, gave much concern to the commander in chief of the American army. Aware of the ex. tremes to which all parties were tending, on January 1 it, 1782 , he returned an anfwer to Governor Chittenden's letter, in which were thefe expreffions; "It is not my bufinels, neither do I think it neceffary now, to difculs the origin of the right of a number of inhabitants to that tract of country; formerly diftinguifhed by the name of the NewhampThire grants, and now known by that of Vermont. I will take it for granted that their right was good, becaufe Congrefs, by their refolve of the $7^{\text {th }}$ of Augutt, imply it; and by that of the $21 \mathrm{ft}$, are willing fully to confirm it, provided the new ftate is confined to certain defcribed bounds. It appears therefore, to me, that the difpute of boundary is the only one that exifts, and that being removed all other difficulties would be removed allo, and the matter terminated to the fatisfaction of all parties. - You have nothing to do but withdraw your jurifdiction to the confines of your old limits, and obtain an arknowledgement of irdependence and fovereignty, under the refolve of the $21 \mathrm{ft}$ of Auguft, for fo much territory as does not interfere with the ancient eftablifhed bounds of Newyork, Newhampfhire, and Maffachuletts.-In my private opinion, while it be hoves the delegates to do ample juftice to a body of people fufficiently refpectable by their numbess, and entitled by other claims to be admitted into that confederation, it becomes them alfo to attend to the interefts of their conftituents, and fee, that urider the appearance of juftice to one, they do not mate$\mathrm{M} \mathrm{m}$ rially 
rially injure the rights of others. I am apt to thin this is the prevailing opinion of Congrefs."

It is only among a free people, that wifdom and virtue can have their full effects. The fortitude, the wifdom, the difintereftednefs, with which $W$ ajhingion had conducted the affairs of the war, through one continued fcene of hardhip and danger, had given him an influence over the minds of the people, which no man in Ámerica, ever had before. It was not merely becaufe he had proved the fuccefsful defender of his country, and the greateft general that had ever appeared in America, but it was the fteadinefs of his integrity and virtue, which gave him fuch an influence over the minds of men: And while the politicians were every where friving for popularity and power, the moft honourable and inportant of a!l diftinctions, was referved for him; a preeminence in the dominion of reafun, wifam, and virtue.

The aflembly of Vermont met in February, at Benningron. The letter from the general was laid before them, and it produced thofe effects which the general feems to have intended: It corretzed the errors of the government of Vermont, and produced: a confidence in the refolves of Congrefs, thus recommended by the opinion and advice of Wafhington. After a full debatc upon the matter, the afinbly refolved to comply with the preliminary; 1u ited of them. Their proceedings were in this requ.

form :

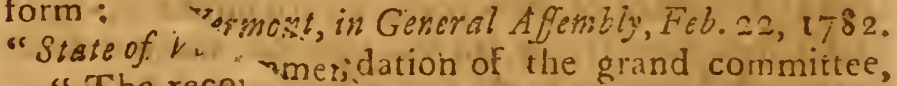
"The recon "mer, dation of the grand committee,

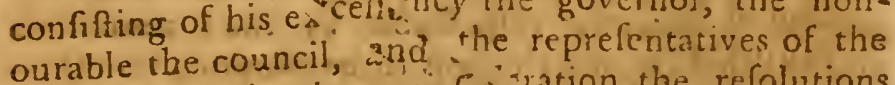
people, on taking into confic ration the refolutions of Congrefs refpecting this faic: in the month of Auguft laft, being read, is as follon's: That in the fenfe of this commitiee, Congrefs by their refolutions of Augult laft, in guaranteeing to the ftaies of Neryyorls 
york and Newhampfhire refpectively, all the territory without certain limits therein expreffed, has eventually determincd the boundaries of this ftate. And whereas it appears to this committee, confiftent with the fpirit, true intent, and meaning of the articles of union entered into by this ftate, with the inhabitants of a certain diftrict of country, on the eaft fide of the weft banks of Connecticut river, and on the weft fide of a line twenty miles eaft of Hudlon's river, which articles of union were executed on the 25 th day of February, and the $15^{\text {th }}$ day of June laft, that Congrefs thould confider and determine the boundary lines of the ftate: It is recommended to the legillature of this ftate, to pals refolutions, declaring their acquiefcence in, and acceffron to the determination made by Congrefs of the boundary lines - between the ftates of Newhamplire and Newyork refpectively, and this ftate, as they are in faid refolutions defined and defcribed. And alfo, exprefsly relinquinhing all claims to, and jurifdiction over, the faid diftricts of territory without faid boundary lines, and the inhabitants thereon refiding.

Confiding in the faith and wildom of Congrefs, that they will immediately enter on meafures, to carry into cffect the other matters in the faid refolution contained, and fettle the fame on equitable terms, whereby this fate may be received into and have and enjoy all the protection, rights, and advantages, of a federal union with the United States of America, as a free, independent, and fovereign ftate, as is held. forth to us, in and by the faid refolutions :

"And that the leginlature canfe official information of their refolutions, to be immediately tranlmitted to the Congrefs of the United States, and to the ftates of Newhamplhire and Newyork refpectively.

"Whereupon refolved,

"That the foregoing recommendation be complied with, and that the went banks of Connecticut riv - 
er, and a line beginning at the northweft corner of the ftate of Maffachufetts, from thence northiward twenty miles eaft of Hudfon's river, as fpecified in the refolutions of Congrefs in Auguft laft, be confidered as the eaft and weft boundaries of this nate. That this affembly do hereby relinquilh all claims and demands to, and right of jurildiction in and over any and every diftrict of territory, without faid boundary lines. That authentic copies of this ref. olution be forchwith officially tranfmitted to Congrefs, and to the ftates of Newhampfhire, and New. york refpectively."

Thus was diffolved an union which had been conftantly acquiring numbers, extent, popularity, and power, from its firlt formation: Which, it was generally believed had prevented the divifion of Vermont, by Newhamphire and Newyork; and which if it had been continued, would probably have extended much further into thofe ftates. It was not without a ftruggle, that the meafure could be effect. ed; and it was not without refentment, that the members from the towns in Newhamplhire and Nowyork, found themfelves excluded from a feat or a vote in the affembly, with which they had been connected by articles of union and confederation, which they fuppofed would have been perpetual.

Having thus fully complied with the refolves of Congrefs, the affembly concluded that all difficulties relating to their admiffion into the confederation of the ftates, were removed. They proceeded* to choofe four agents and delegates, to reprefent the ftate of Vermont in Congrefs; and requefted the governor to commiffion them with plenary powers, to negociate the admiffion of Vermont, into the confederation of the United States; and when the ftate was admitted, two of the agents were empowered to

\section{* February 28.}


take their feats, and reprefent Vermont in Congrefs. The agents were accordingly commiftioned, " to negociate and complete on the part of Vermont, the admiffion thereof into the federal union with the United States of Northamerica. And in bchalf of the frate, to fubfcribe articles of perpetual union and confereration therewith."

While the affembly of Vermont was thus employed in effecting a compliance with the relolves of Conurefs, warm debates had taken place in that affembly, relpecting the meafures that ought to be purfued with Verment. The refufal of the legiflature in October, to comply with the refolve Congrefś had paffed on Auguft 20:h, was viewed in a very unfavourable light. On March $1 \mathrm{ft}$, it was propofed in Congrefs to pafs a refolve, that if within one month from the time in which the refolve fhould be communicated to Thomas Chittenden, the inhabitants of Vermont hould comply with the refolves of Auguit 7 th and 20 th, 1781 , they fhould be immediately admitted into the union, but if they thould refufe this, and did not defint from attempting to exercife jurifdiction over the lands guarantced to Newhamplhire, and Newyork, Congrefs would confider fuch neglect or refufal, as a manifelt indication of defigns hoflile to the United States, and that all the pretenfions and applications of the faid inhabitants, heretofore made for admiffion into the federal union, were fallacious and delufive; and that thereupon the forces of the United States, fhould be employed againft the inhabitants, and Congrefs would confider all the lands within the territory to the eaftward of the ridge of mountains, as guaranteed to Newhamphire; and all the lands to the weftward of faid line, as guaranteed to Newyork; and that the commander in chief of the armies of the United States, do without delay or further order carry thefe refolutions into full execution.-But af. 
ter warm debates, and repeated trials, a vote could not be obtained to adopt thefe refolutions, and the matter fubfided.*

The refentment Congrefs difcovered, at Vermont's sefufing to a rree with her refolves, was but of a thort duration. In a few day's the agents arrived at PhiJacelphia, and on March 31 f, officially laid before that body, the compliance of the leginlature of $\mathrm{Ver}$ mont, with their relolutions of the 7 th and 20 th of Auginft.

The matter was referred by Congrefs, to a committee of five of their members. On the 17 th of April, the committee made the following report, "In the fenfe of your committee, the people of the faid difirict by the latt recited act, have fully complied with the Ripulation made and required of them, in the refolutions of the 2oth and $21 \mathrm{ft}$ of $\mathrm{Au}$ gunt, as preliminary to a recognition of their fovereignty, and independence, and admiflion into the federal union of the ftates. And that the conditional promile, and engagenent of Congrefs of fuch recognition, and admifion, is thereby become abfolute and neceffary to be performed. Your committee therefore fubmit the following refolution :

"That the diftrict or territory called Vermont, as defined and limited in the refolutions of Congrefs of the soin and $21 \mathrm{ft}$ of Auguft, 1781, be, and it is hereby recognized, and acknowledged by the name of the flate of Vermont, as free, fovereign, and independent; and that a committee be appointed to treat and confer with the agents and delegates from faid fate, upon the terms and mode of the admiffion of the faid ftate into the federal union." - When this report was read in Congrefs, a motion was made and feconded, that the firt Tuefday in Oetober next - be afigned for the confideration of the report : The vote

* Journal of Congre? $3_{8}$ Marsh 1, 1782, p, 298-305. 
vole palled in the negative. A motion was then made and feconded, that the third Tuelday in June next, be affigned for the confideration of the report: The vote was again in the negative. A motion was then made and feconded, that Monday next be affigned for the confideration of the report; and the vote was alfo found in the negative, for the third time.*

From thefe votes it was apparent, that Congrefs had again adopted their former policy of evafion, and did not mean to come to any decifion upon the affairs of Vermont. Having no profpect of fuccefs in their agency, the agents concluded their bufinefs, $t$ with a letter to the prefident of Congrefs, reprefenting that Vermont, in confequence of the faith which Congrefs had pledged to them, had been prevailed upon to comply with their refolutions, in the moft ample manner ; that they were difappointed by the unexpected delay of Congrefs, in not executing on their part, the intent and fpirit of the refolve; that Vermont was now reduced to a critical fituation, by calting off a confiderable part of her ftrength, in being expofed as a forlorn hope, to the main force of the enemy in Canada, and deftitute of the aid of the United States; which made them urgent that unneceffary delay might not deprive them, of the benefit of the confederation; and that they fhould expec to be officially acquainted, when their attendance would be neceffary. $t$

The proceedings of Congrefs, ought to be treated with all the refpect, which is due to government, and with all the candour that is due to the imperfection of man. But when every reafonable allowance

* Extract from the minutes of Congrefs, of April 17, 178z,

+ April 19.

¥ Copy of the letter from the Hon. Jonas Fay, Mofes Robinfon, and Iraac Tishanor. 
ance is made, their conduct in this aftair, cannot be confidered in any other, than an unfavour. W light. There could be no neceffity of evafive notici; al a period, when the public fentiment cilled fo, the decifion of a queftion, which had already orcafroced fo much trouble and danger. The refolves Congrefs had paffed on Auguft $7 \mathrm{th}$, and 20 th, 1781 , could not be underftood in any other fenfe, than as a conditional engagement or promife on the part of Congrefs. The conditinn had been fully complied with. In that fage of the bufinefs, to refolve their own engagements into nothing, had not the appearance of wifdom and found policy, but of art, cunning, and littlenefs. Their own faith and honour, and what ought to have bcen infinitely dear to them, the honour of their general, required the moft unequivocal and punctual performance of what they had virtually engaged, and led the people of Vermont to confide in.- Nor would the agents of Vermont have been wrong, if they had expreffed in terms more ftrong and decifive, their inclignation at the public trifling of a bodv, whole public meafures ought to have been marked, in every inftance, with the $\mathrm{fricteft}$ faith, the greateft integrity, and the molt delicate fenfe of honour.

When the laft refolutions of Congrefs became known in Vermont, the general opinion was, that the affernbly liad been duped by the finefle of Congrels, to bring themfelve's into a fate more weak, and dangerous than they had been before: And that there would be no fafety, in being guided by refolutions, which might be formed, and changed, amidn the intrigues and cabals of parties. Both the people and the affembly of Vermont, feem to have been determined by the meafures of Congrefs, to maintain their own independence, to adhere to the boundaries to which they had agreed, and to defend themfelves by force againn any body of men who fhould en. deavour 
deavour to diffolve, or to difturb their government ; and not to make any further folicitations to Congrefs, to receive them into the confederation. But that no blame might be laid upon them, or any deficiency be found in their proceedings, the general affembly at their annual feffion in October, again appointed agents with full powers and inftructions, to negociate and complete the admiflion of Vermont into the union of the flates. 


\section{H A F. XI.}

Difturbances in Vermont. Refolution's of Congrefs. Remonfsrances againft the Proceedings of Congress. Peace with Greatbritain. Difinclination of Ver. mont to an Union with the Confederaled States. New Federal Conftitution. Propofals of Neweryork. Settlement of the Controveryy with that State. Ad. miffion of Vermont into the Federal Union. P'olit. ical Effects of the fe Controverjies.

IN the internal government of the flate, Vermont had met with good fuccels. The people were not fully united in the meafure, when the powers of government were fir $\Omega$ affumed. Some were upon principle, attacbed to the governnent of Newyork. Thofe who were of a timid conftitution, were fearful of the confequences. Thole who wilhed to be free from the reftraints of law and government, were clamorous about ty ranny and oppreflion. Several of thefe fought protection from Newyork, avowed their allegiance to that flate, and received commiffions for civil and military offices, under that government; and were extremely active to cppofe, and diflurb the government of Vermont. Notwithftanding thefe attempts, the government of Vermont had been conftantly gaining frength, not only among the people who were already fettled in the territory, but by the acceflion of large numbers of people 


\section{IIISTORY OP VERMONT.}

people from other ftates, but chiefly from Connecticut. The new fettlers were almoft univerfally, in favour of the proceedings of the government,; and were adding much every year, to its ftrength, num. bers, and unanimity. IVith thefe profpects the legiflature judged that a general act of amnefty, in favour of thole who had been in oppofition to government, might be of ufe to reconcile and quiet thofe, who were now fully convinced, that nothing could be carried againft the government, by force and oppofition. According!y in February, 1781, the legillature paffed a general act of amnefty, in favour of fuch perfons within the ftate, as had previoufly made oppofition to its authority. Upon this judicious extenfion of lenity, all oppofition to the internal government of Vermont, had ceafed for more than a year; and all parties within the ftate, feemed to acquiefce in the fupport of government.

Congrefs had withdrawn all the continental troops, and left the inhabitants to take care of themfelves. In their expofed fituation, it became necelfary to raife a body of troops, for the defence of the frontiers. The legillature ordered them to be railed from the feveral towns, in the ftate, in proportion to the number of their inhabitants. There were fome perfons in the foutheafterly parts of the ftate, who oppoled the raifing and payment of thefe men. The governor of Newyork by letters to them, and otherwife, interfered in the bufinels. To fome of thefe difaffected perfons he gave civil and military commiffions, and encouraged them with the profpect, or promile of fupport and protection.* Made infolent by this profpect of fupport and diftinction from the government of Newyork, fome of thefe difaffected perfons, had the effrontery to attempt to exercile the laws of Newyork, over the citizens of Vermont,

in

* Remonarance of the Council of Vermont, p. $: 8$. 
in avowed contempt and defiance of her autharity. Infolence fo audacious, adinitted of no other treatment, than the punifhment, which civil laws affign to fuch crimes. Lenient meafures proved in vain, and the government of Vermont ordered a military force to be fent to affift the theriff of the county of Windham, and to protect the courts of juftice again $t$ an armed violence and oppofition. Five of the mott obnoxious of the criminals were banifhed, and fundry others were annerced in pecuniary fines, according to the cuftomary and due forms of law. The offenders had been guilty of that avowed and armed oppofition to law and government, which in every country is denominated treafon and rebellion. But great care was taken to avoid the effufion of blood, and to have the punifhment of the offenders extended no further than was neceffary, to preferve the in. dependence and fafety of the ftate.

Difappointed in their views and expectations of producing an infurrection in Vermont, checked and reftrained by the proceedings of her courts, nothing remained for them but to leek fupport and reward from the government, under whofe authority they pretended to have acted. But it was not in the power of Newyork, to afford them fuch relief as they xwifhed: Neither her power, or policy, her promifes. or her threatenings, would have had the leaft effect upon the people, or the government of Vermont. Nothing remained but an appeal to Congrefs. Complaint was made to that body, that their relolutions of Sept. 24, 1779, and of June 2, 1780, were pubIicly violated; and that Vermont had proceeded to exercife jurifdiction over the perfons and properties of fundry perfons, who profeffed themfelves to be fubject to the ftate of Newyork. Congrefs took up the complaint, and referred it to a committee. On No.vember the $14^{\text {th }}$, the committee reported, "that the meafures complained of, were probably occafioned by 
By the fate of Newyork having lately iffued com. miffions, both civil and military, to perfons refident in the diftrict called Vermont:" And that it be recommended to Newyork, to revoke all the commiffions which they had iffued fince the month of May; that it be recommended to the inhabitants to make full fatisfaction to the perfons, who had fuffercd damages; and that it be recommended to Newyork, and to the people exercifing government in Vermont, to adhere to the refolutions of Congrefs, of Sept. $24^{\text {th }}$, until a decifion thould be had upon their affairs. But after feveral attempts, a vote could not be obtained in favour of thefe refolves, and the matter was adjourned.*

On December the $5^{t h}$, the bufinefs was taken up again; and Congrefs, inftead of proceeding to fulfil her own engagements to Vermont, was led by an ill judged policy, to embrace the caufe of the criminals, and to pals refolutions full of cenfure and threatening, againt the proceedings of the ftate. Their refolves were in this tyle :

"By the Unitea Siates in Congrefs afrembled, Dec. 5, 1782. Uhereas it appears to Congrels by authentic documents, that the people inhabiting the diftrift of country, on the weft fide of Conneclicut river, commonly called the Newhamphire grants, and claiming to be an independent ftate, in contempt of the authority of Congrefs, and in direct violation of their refolutions of the $24^{\text {th }}$ of September, 1779 , and of the $2 \mathrm{~d}$ of June, 1780 , did, in the month of September laft, proceed to exercife jurifdiction over the perlons and properties of fundry inhabitants of the faid diftrict, profefling themfelves to be the fub. jects of, and to owe allegiance to the ftate of Newyork; by means whereof divers of them have been condemned to banifhment, not to return on pain of death

Journal of Congrels, Nov, 14, 178 , 
death and confifcation of eftate, and others have been fined in large fums, and otherwife deprived of property. Therefore, Refolved, That the faid acts and proceedings of the faid pcople, being highly derngatory to the authority of the United States, and dangerous to the confederacy, require the immediate and decided interpofition of Congrefs, for the protection and relief of fuch as have fuffered by them, and for preferving peace in the faid difrict. until a decifion thall be had of the controverfy rel. ative to the jurifdiction of the fame.

"That the people inhabiting the raid diftrict claiming to be independent, be, and they are hereby required without delay to make full and ample reftitution to Timothy Church, Timothy Phelps, Hen. ry Evans, William Shattuck, and fuch others, as have been condemned to banifhment and confilcation of eftates, or have otherwife been deprived of property, fince the firft day of September laft, for the damages they have fuftained by the acts and proceedings aforefaid, and that they be not molefted in their perforis or properties, on their return to their habitations in the faid diftrict.

"That the United States will take effecisal meaf.. ures to enforce a compliance with the aforefaid refolutions, in cale the la me fhall be difobey'ed by the peo. ple of the laid diftrict."

The people of Vermontwere already prejudiced againt the proceedings of Congrefs; thefe refolutions could not fail to impair, all that remained, of reverence and refpeet. The governor and council fent a fpirited remontrance to Congrefs againt thefe refolutions.* In this remontrance Congrefs was reminded of their folemn engagements to the ftate of Vermont, in their public acts of Auguft 7 th, and $21 \mathrm{ft}, 1781$, which had been fully complied with on the pait of the ftate,

- Jan. 9,1783 . 
lut which Congrefs had refufed or negleced to ful w fil : They were told that by their own articles of confederation, they had no right to interfere, or meddle with the internal police of any of the United States; and lealt of all with that of Vermont, from which they had not received any delegated authority whatever: That Vermont had as good a right to independence, as Congrefs; and as much authority to pafs refolutions prefcribing meafures to Congrefs, as Congrefs had to prefcribe meafures, directing them to receive the banifhed, and make reftitution to criminals of the property which had been taken from them by due courfe of law, for their crimes againft the laws and authority of the ftate: 'They were reminded that they were purfuing the fame meafures againft Vermont, which Britain had ufed againft the American Colonies, and which it had been judged. neceffary to oppofe at erery rifk and hazard: That their proceedings tended to make the liberty and natural rights of mankind a mere bubble, and the fport of ftate politicians: That it was of ro importance to America to pull down arbitrary power in one form, that they might eftablifh it in another: That the inlabitants of Vermont had lived in a Rate of independence from the firlt fettlement of the country, and could not now fubmit to be refolved out of it by the influerice which Newyork, their old adverfary, had in Congrefs: That they were in full poffeffion of freedom, and would remain independent, notwithftanding all the power and artifice of Newyork: That they had no controverfy with the United States, complexly confidered; but were at all times ready and able to vindicate their rights and liberties, againtt the ufurpations of the ftate of Newyork.

With regard to that part of the refolves, which declared "the proceedings of Vermont to be derog. atory to the authority of the United States, and dangerous 
dangerous to the confederacy, and fuch as required the immediate interpofition of Congrefs to relieve the fufferers, and preferve peace," they anfwer, That it appears like a paradox to affert that the exercife of civil law in Vernont thould be derogalory to the authority, or dangerous to the confederacy of the United States; or that the interpofition of Congrefs. would be the means of eftablifhing peace in the ftate. Law, juftice, and order, they affert were eftablifhed in Vermont, before Congrefs paffed their late refolutions; what difcord they would occafion, time would determine : But that it was the general opinion that a ratification of their fipulated agreement. would have had a more falutary tendency to promote peace, than their late refolutions.

As to the requifition that "the ftate without delay make full and ample, reftitution to thofe who had been condemned to banifhment and confifcation of eftate," they obferve, That Congrefs has been fo mutable in their refolutions refpecting Vermont, that it is impoffible to know on what ground to find them, or what they defign next. At one time they guarantee to the ftates of Newhampthire and Newyork, their lands to certain defcribed limits, leaving a place for the exiftence of the ftate of Vermont; the next thing Vermont hears from them, is, they are within thefe limits controlling the internal government of the ftate. Again, they prefcribe preliminaries of confederation, and when complied with on the part of the ftate, they unreafonably procraftinate tho ratification.

To that part of the refolves in which the fate was threatened, "that the United States would take effeclual meafures to enforce a compliance with their refolutions, in cafe they fhould be difobeyed by the people of faid diftrict," they return for anfwer, "That the fate would appeal to the junice of his excellency Geueral Wafhington; and as the general and moft 
molt of the inhabitants of the contiguous fates, were in favour of the independence of Vermont, it would be more prudent for Congrefs to refer the fertlement of this difpute to the ftates of Newyork and Vermont than to embroil the confederacy with it.-But fuppofing Congrefs had a judicial authority to controul the internal police of the ttate, the ftate had a right to be heard in its defence: That the proceedings of Congrefs were wholly unjuftifiable, upon their own principles; and that coming to a decifion of fo important a matter, exparte, and without any notice to the ftate, was illegal, and contrary to the law of nat ture and nations. - The remonftrance was concluded with folicicing a federal union with the United States, agreeable to their preliminary agreement, which their committee had reported, was "become abfolute and neceffary on their part to be performed:" and from which, they were affured, Vermont would not recede.

The affembly met in the month of February, and fent their remonftrance to C.ongreis. Like that of the governor and council, this was alfo plain, fpirited, and decifive; announcing to Congrefs in the plaineft terms, that they fhould not intermeddle in the internal affairs of government; and that rhey were fully refolved, to maintain their indegiendence.

The effect produced by thefe aets of Congrefs; was in every refpect different, from what that body feem to have expected. Inftead of being awed into fubmiftion, the people and government of Vermont concluded they were produced by the influence of Newyork; and determined that they never flould be executed. The evafive, irrefolute, contradictory acts of Congrefs, had nearly deftioyed all the faith and confidence, which the people of Vermone had repofed in that body: And it was generally thougiti it would not be beft, to have any connexion with them; but only to keep up the cuitom and form of 
298、THE NATURAL AND CTVIL

choofing delegates every year, to reprefent the flate of Vermont.

The war with Greatbritain, had proved greatly diftreffing to every part of the United States; bus it had ferved to eftablifh an union among the people of America, which could not have been fo firmly cemented, but by the profpect of common danger. This appearance was now come to an end. On fanuary the 20 h, 1783 , the preliminary articles of peace were figned by the miniflers of the king of Greatbritain, and the United States of America: In this treaty the former colonies were acknowledged to be free, forereign, and independent flates. By putting an end to the war, this treaty put an end to the embarraflments of Congrefs, and to all the fears of the people of Vermont. An union with the confederation, was no longer a matter of immediate and urgent neceffity. The flate had now no exter. nal enemies to oppofe, or any body of troops to be raifed, or kept in pay. Weary of fo long and difo trefting a war, all parties wifhed for the repofe and tranquillity of peace; and were heartily defirous of dropping ali occalions of controverfy and debate. The bufinefs of Congrefs however, becarne more and more embarralfing. Their currency had failed, their revenues vere exhaulted, their armies were diffatisfied and unpaid, the debts they had contracted were unfunded, the pubtic creditors weie every where full of complaints againft their proceedings, and they had no refources to anfwer the demands that were perpetually made upon them. Few of the ftates paid much regard to their refolutions, and it was now fully evident that their powers were inadequate to the public bufinels of the United States, and that the articles of union and confederation were effentially defective. Without power to relieve themfelves under thefe embarraffments, the Congrefs was daily finkirg into a fate of infignifi. cance 
cance and contempt; and the public affairs of the union were conftantly becoming more and more em. barraffed with weaknefs, diforder, the want of wifdom, credit, and power.

In fuch a fate of things, an admiffion into the confederacy of the ftates, ceafed to be an object of any importance, or even defire. Vermont was happy in being free from the load of debt, which lay upon the United States; and was not perplexed by the conftant calls of Congrefs, to raife the neceliary fums of money. The legifluture had acquired witdom and experience in governing the people, from the difficulties in which they had been engaged. It had not been in their power to contract very large debts, nor was it neceffary or practicable to impufe heavy taxes upon the people. The ftate had a large quantity of valuable lands to difpofe of ; and purchafers and fettlers were conftantly coming in from all the Newengland ftates. - Thus, by one of thole fudden tranfitions which are common to hizman atfairs, from the mont diftreffed and ierplexed ftate, the condition and profpect of the people of Vermont, became at once more ealy and flattering than thole of their neighbours. Encouraged by the mildnefs of the government, the fmallnefs of the taxes; the fertility and cheapnefs of the lands, large additions were annually made to their numbers and property, by the acceffion of inhabitants from other ftates. There was nothing therefore in the public affairs of the United States, or in thofe of Vermont, that could lead the inhabitants any longer to wifh for an admiffion into the confederation. The body of the people felt that they were in a better fituation, than the people in the neighbouring fates: And it was the general inclination and defire not to be connected with the union, if it could be decently avoided.

In this fituation things remained, until feveral of the leading men in the United States, became alarm: 
ed with the operation and tendency of public affairs. Statefmen of ability and information faw that the powers invefted in Congrefs, were in effeet, only the powers of a diplomatic body; and wholly inadequate to the purpoles of federal government : And that the liberties, the fafety, and the union of America, could not be preferved, unlef's an adequate and efficient government could be eftablifhed in the United States. Virginia had the honour to lead, in the firlt avowed oppofition to the Britih king and parliament: And the was the firft that attempted to call a convention of the flates, to form a new federal conftitution. The meafure was crowned with that fuccefs, which might be expected from the deliberate confultations of a free and uncorrupted people, aiming to fecure the public fafety. A new fed. eral conftitution was adopted by the people of America : And a new Congrefs, furnithed with competent porvers, met in the city of Newyork, March 3d, 1789 .

Like the other eitizens of America, the people of Vermont were anxious to know, what would be the policy and proceedings of the federal government. Their intereft had not been much promoted by the meafures of the Congrefs, with whom they had formerly tranfacted bufinefs. But there was now a general expectation among the pecple, that fomething wifer and better, was to take place : But they had learned from experience, that there was no oth. er way to judge with certainty, of the excellency of any conftitution, or government, but by the good which it did to the people. In the courfe of one or two feffions, they found the federal government had been labouring to reftore the public credit, to do juftice to the public creditors, to provide for the payment of the public debt, and to eftablifh a fycrem of equal law and juftice, in every part of the federal government. Meafures thus marked with wildom 
wifdom and juftice, ferved to abate the fears that many had entertained, and to conciliate the minds of the people to federal fentiments : And the profpect leemed favourable, that every part of the American ftates might be brought to a\& with union and vigour, in fupport of the federal fyftem.

But the ancient difficulty with Newyork, was not yet removed. That ftate had indeed given up all profpeet, and probably all defire, of fubduing Vermont by force, or by policy; and well knew that Vermont was, and would remain, a free and inde. pendent. ftate. But large tracts of land had been granted by the governors to individuals: Thefe tracts of lands, by means of the increafing fettlements and profperity of Vermont, were become great!y valuable. The government of Vermont hid uniformly refuled to acknowledge the validity of thefe grants, or fubmit to any of the legiflative aets of Newyork, and had made new grants of all thofe tracts of land: And was unalterably fixed in refufing to admit the legality of any legiflative aet of Newyork, which related to the territory of Vermont, The grantees under Newyork, were conftantly complaining of the injuries that were done to them, in not being permitted to take poffeffion of their property ; and of the injuftice that would be eftablifred, if the government of Newyork fhould fuffer their lands to be thus taken from them without an equivalent. Much pains had been taken to compromire the difficulty, but without coming to any general agreement : And the government of Newyork did not conceive any very ftrong obligation lay upon them, to refund that to individuals, which the ftate had no hand in granting; but which was fimply an act of the crown of Greatbritain, executed by the will of the royal governor ; generally for his perfonal profit, always for the benefit of his particular fricnds, 
but never for any emolument to the government or people.

A courfe of events at length occurred, which rendered the riews of Newyork, nore favourable towards I'ermont. Difputes relative to the permanent feat of the federal government, ran high in Congrels. After repeated trials, the decifion fometimes fell in favour of remaining at Newyork, and fomelimes in favour of removing to Philadelphia; and it was finally carried in favour of Philadelphia, by a very fmall majority. Kentucky, it was forefeen, would foon be admitted into the federal union: And Virginia, to whofe territory it belonged, with great dignity and honour, inftead of oppofing, was aining to promote that event. The reprelentation from the eaftern ftates, was diminithed of its juft proportion, by the exclufion of Vermont ; and this had already proved to the difadvantage of Newyork. If their old controverfy could be fettled, it was ap. parent that the interefts and influence of thefe ftates, would in almoft every inftance coincide. - The pub. lic. fentiment called loudly, for the fame meafure. To what purpole, it was faid, is Vermont kcpt out of the union?-Is it not in the full and complete proffeffion of independence; and as well regulated and governed as the other ftates?-And fhall the federal union throughout the whole teritory, be obfluced, and rendered incomplete, by the ancient and endlefs controverfy, between Newyork and Ver. inont?

Newyork withed with the ref of America, to have the federal union completed : And without calling to view the former occafions of contention, paffed an act, July 15,1789, appointing commiffioners with full powers to acknowledge the independence of Vermont, and to fettle all matters of controverfy with the fate. On Odtober the $23 \mathrm{~d}, 1789$, the legiffature of Vermont appointed commiffoners on their 
their part, to treat with thofe of Newyork, with powers to adjuft, and finally determine, every thing which obftructed the union of Vermont with the United States. - The commiffioners from both ftates, were themfelves very defirous to have Vermone brought into the federal union. The only point of difficulty and debate, related to a compenfation for the lands claimed by the citizens of Newyork, which had been regranted by the government of Vermont. After two or three meetings of the commiffioners, the matter was brought to an equitable and amicable agreement.

October the 7 th, 1790, "the commiffioners for Newyork by virtue of the powers to them granted for that purpofe, declared the confent of the legiflature of Newyork, that the ftate of Vermont be admitted into the union of the United States of America; and that immediately upon fuch admiffion, all claims 'of jurifdiction of the ftate of Newyork, within the ftate of Vermont, thall ceafe ; and thenceforth the perpetual boundary line between the ftate of Newyork, and the ftate of Vermont thall be" as was then holden and poffeffed by Verrnont, that is, the weft lines of the moft weftern towns which had been granted by Newhampfhire, and the middle channel of Lake Champlain.-With regard to the lands which had been granted by Newyork, "the faid commiffioners by virtue of the powers to them granted, declare the will of the legiflature of Newyork, that if the legiflature of the fate of Vermont fhould, on or before the firft day of January, 1792, declare that on or before the firft day of June, 1794 . the faid ftate of Vermont would pay the ftate of Newyork, the fum of thirty thoufand dollars, that immediately from fuch declaration by the legiflature of the ftate of Vermont, all rights and titles to lands within the ftate of Vermont, under grants from the government of the colony of Newyork, or from the 
frate of Newyork, fhould ccafe," thofe excepted, which had been made in confirmation of the grants of Newhan pthire.

This propofal and declaration beirg laid before the legiflature of Vermont, they very readily agreed to the plan, which had been concerted by the commillioners from both ftates; and on October 28 , 1790, paffed an act directing the treafurer of the Iate, to pay the fun of thirty thoufand dollars to the ftate of Newyork, at the time propofed ; adopting the weflern line, as the perpetual boundary between the two ftates; and declaring all the grants, charters, and patents of land, lying within the ftate of Vermont, made by or under the late colony of Newyork, to be null and void, thofe only excepted which had been made in confirmation of the grants from Newhampfinirc.

In this amicable manner, was terminated a controverly, which had been carried on with great animofity for twenty fix years. Both fides were weary of the conten, and happily for them, the general ftate of America led to moderation, equity, and wifdom: And this feems to have been the only period, in which the matter could have been adjufted to the fatisfaction of all parties.

The difficulties with Newyork being thus removed, the affembly of Vermont proceeded to call a convention of the people, to take into confideration the expediency of joining the federal union. The convention inet at Bentrington, January 6, 1791. The members were not all agreed in the expediency of being conneeted with the thirteen fates: And it ras doubted whether a majority of the people, were for the meafure. Several members of the conver. tion wifhed to defer the confuderation of the queftion, to a more diftant pesind. It was urged on the other baud, that the fately, the intereft, and the honour of Vermont, would be effentially promoted 
by joining the union of the other ftates ; and that this was the precife time, when it might be done without difficulty, or oppofition. A large majority of the members were convinced that the matter could not be put off any longer; and after a debate of three days, the queftion was carried in the affirmative, by a majority of one hundred and five to two. This being the only bufnefs for which the convention had been called, it was diffolved January 11 th. The general affembly of Vermont met at Bennington, January the $10 \mathrm{th}$. On the $18 \mathrm{th}$, they made choice of the Honourable Natbaniel Cbipman, and Lewis $R$. Morris, ESq; their commiffioners to attend Congrefs, and negociate the admiffion of the ftate into the union of the confederated ftates of America. The commifioners repaired to Philadel. phia, and laid before the prefident of the United States, the acts of the convention and legiflature of Vermont ; and on February $18 \mathrm{th}, 1791$, the admiffien of Vermont was completed, by an act of Congrefs, without any debite, or one diffentient vote. By this event all the con troverfies refpecting Vermont, were brought to a conclufion: She was to take her feat in Congrefs, March 4, 1791 ; and the federa! union was completed, in every part of the Unitcd States of America.

The violence and duration of the controverfies, in which Vermont was to long engaged, proved unfavourable to the ftate of fociety in that, and in the ac's jacent ftates. During the firft part of their conteft with Newyork, there was not any fettled form of government in Vermont. The peop?e tranfaled their bufinefs, by the meetings of towns and planta. tions; by committees, leaders, and officers, appointed and fubmitted to, by gencral confent. The oppofi tion to Newyork was one continued feene of violence, and the minds of the fettlers svere conftantl. agitated by the mont uncomfortable paffions : But a 
general fear of the final iffue, prevented both parties from proceeding to bloodfhed. But in one inftance, was there any perfon flain, in this quarrel. In Marcls 1775, during the feffion of a court holden under the authority of Newyork at Weftminfter, one man was fhot through the body in the court houfe. But it gave fuch a general alarm, that both parties were more cautious to avoid the extremes of irregularity. In this ftage of the controverfy, the fettlement of the country was much prevented by the contrary claims which fubfifted, and the violences they produced.-In the latter part of the year, 1781, the controverfy with Newhampthire bore a very ferious afpect. Chefterfield in that ftate, was one of the towns which had joined with Vermont; but fome of the inhabit ants fill adhered to the jurildiction of Newhampfhire. A conflable under the authority of Vermont, went to ferve a wit upon one of the inhabitants of that town. His authority was denied, and an offcer, under the authority of Newhamplhire, interpofcd. In the courfe of the conteft, the Nerisamplite officer with one or two of his adberents, were imprifoned by the officer from Vermont. Orders were given by the government of Niewhampfhire, to raife the poffe comitalus, and liberate the imprifoned fheriff by force. The governor and council of Vermont fent three agents to Exeter, to endeavour to compromile the matter with the government of $\mathrm{New}$ hamplhire. One of thefe was a fheriff of Vermont : By way of retaliation, he was inmediately imprifoned at Exeter. Alarmed with this approach to hoftilities, both governments were obliged to interpole to provent more violent meafurcs, which threatened to break out into a civil war.-In 1784 , the fecretary of Vermont was arrefted in the city of. Newyork, on account of his political conduet in Vernont: The matter beis; laid before the general atrembly of the flate, they unanimouny refolved that fuch lands 
in the territory of Vermont, as belonged to the citizens of Newyork, fhould be fold, until money enough was raifed from their fales, to make full reftitution to their fecretary for all the charges and damages which might accrue, from his arreft in Newyork.

Thele violences were unfavourable to the fettlement of the country; they tended to kecp the minds of the people, in a fate of irritation; and had an ill effect on the fate of fociety. But it is worthy of remark, how extremely unwilling the people of America were, to proceed to war with one another. In their higheft ftate of provocation and refentment, they abhorred the idea of killing and flaughtering each other. Unufed to the practices of rebellion, murder, and affafination, when they were exafperated with the higheft fenfe of injuries, they had no intention or idea of kindling a civil war in their country, of defroying thole who oppofed them, or of Ataining the American fyltem of freedom, with blood and naughter. So far from this, that anidft a violent oppofition to one another, they were all agreed, that the war fhould be carried on with unceafing vigour againft Greatbritain; but that no other war fhould be permitted to exift in the country.

But although all parties had cautiounly avoided enkindling a civil war in their country, they had been hurried into great millakes and errors. The people of Vermont had no idea of oppofing the government of Newyork, until the governor and council of that province had proceeded to nake nerv grants of their lands, which they had bought under the royal grants, and fubdued by extreme labour and hardfhip. To relinquilh all their property, to reduce themfelves and families to a fate of beggary, and fubmit to have all the profit of the labour and fufferings of their whole lives wanton!y taken from: them, and given to others; there was an infolence and cruelty in this kind of oppreffion, to which they 
ought not to have fubmitted, fo long as it was in their power to prevent it. Inftead of being foftened, the iniquity of this oppreflion was increaled, by its being committed under the oftentatious authority of the king, the law, and the government of New. york. The lettlers certainly did right in oppoling fuch pretentions, and proceedings. They felt with an irrefifible evidence, that the natural rights of men, were of an higher original, and of a more fa. cred authority, than the variable decifions of a Britith king, or the rapacious views of a provincial governor, and council: Such oppofition to thefe pro. cecdings, as was neceffary in order to be cffectual, was undoubtedly juftifiable by the law of nature and nations, - But Vermont was not without error, in fuffering the fixteen towns from Newhamplhire, to join with her. This was opening the door to irregularity, and confufion; and in the event, was of more difadvantage, than benefit; and ought, in the firft inftance, to have been prevented. But when Newhamplhire and Newyork were aiming to divide the whole territory of Vermont between them, Vermont was not blameable for defending herfelf by the fame policy, and receiving their towns and fettle. ments into her confederation.

Newyork had a proper right to claim the jurildiction of the whole territory, which the royal decifion had affigned to her, in 1764: And had the been content with this, there never would have been any controverfy about the matter. Her great error was in regranting the lands, and ejecting the fettlers from the eftates, which they had honeftly bought before of the highelt Britioh authority; and made valuable by their labour, fufferings, and hardfhips. It is true, the proceedings of Newyork were all agreeable to the forms of their laws : Inftead of being a juftification of thofe proceedings, the abufe and cruelty pecame greater from this circumftance; for injultice, 
is moft of all odious, when it is calmly and deliber. ately done, under the colours of law and govern. ment.-Under the roya! governments fuch proceedings had not been altogether uncommon, nor was it in the power of the people to prevent them : But when the people had taken the powers of government into their own hands, thele errors certainly ought to have been corretted. A perfeverance in the fame error, feems to have rendered the clains of Newyork, difagreeable to Congrefs; and in the event, united the public opinion, in oppofition to her claims, and in favour of thofe of Vermont.

Newhampthire had juft occafion for offence, at the proceedings of her citizens, in the feceding towns; and with the government of Vermont, for receiving them into her confederation. But there was not, either found policy, or any advantage, in extending her claim over the whole territory: No colour of title, or any pretence of right, could be found for fuch a claim; and the defign of it was perfectly well underftood.

How far Congrels was forced to adopt an evafive policy, by the circumftances of the war, it may be difficult for thofe who were not in the cabinet, to determine. Her great bufinefs, undoubtedly was to preferve peace and union among the ftates; and to prevent their contentions, from injuring the common caufe. This end was effected: But it does not feem to have been produced by the policy of Congrefs, but by the virtue of the people. The meafures of Congrefs refpecting the controverfies of Vermont with Newhampthire and Newyork, ferved rather to difpleafe all parties, than to fatisfy any. Such was their uncertainty, their contradictory, and evafive nature, that when the dangers occafioned by the war were removed, the people of Vermont had very little defire or inclination to be much connected with Congrefs. It was not until more fteadinefs, vigour, and 
and ability, appeared in the federal government, that the people were willing to be brought into the American union.

Amidt the errors and evils which attended there controverfies, they were found to produce fome good effects. They' ferved to exercife and draw forth abil. ities and powers, which proved of great fervice to their country, when they came to be employed in the grand conteft with Britain. They led the pcople to acquire juf fentiments of the rights of men, and of the nature, importance, and extent of government. At that period, every thing in Ametica reemed to operate, to promote political knowledge. 'The principles of civil liberty, which were but imperfealy confidered in the writings of zocke, Syd. ney, and Montelquieu, occurred every moment to the vicws and feelings of the whole body of the peo. ple: Inftead of being any longer barely the dificoveries of a ferv enlightened philolophers, they becane the prevailing fentiments of the whole body of the American citizens: And from that period until now, they have been conftantly operating to produce a more naturąl form of government, a more perfect sy nem of freedom, and a more flourifhing flate of fociety in America, than ever had been kuown before, among all the affaciations of men. 


\section{H A P. XII.}

StATE OF SOCIETY.-Tbe Employmenss of the Peo. ple: Agriculiure, Manufaetures, Hunting, Commerce, the Profits of Labour.

\section{IN the natural conftitution of man;}

the author of nature feems to have eftablithed the Iimits, below, and above which, the huınan race canrot be found. Somewhere within thefe limits, every nation will take its place : But where, depends chiefly upon the ftate of fociety. It fhould feem that feveral of the nations of the earth, are yet near the ultimate point of depreffion; and have been fo, from time immemorial. But what is the ultimate point of perfection to which men may rife, we cannot determine. The many and great imperfections, which attend the ftate of fociety in every nation, feem to denote that none of them have as yet, made very near approaches to it.

The caufes which produce the degradation, or the fuperiority of one nation to another, will always be found in thofe things, which have the greateft effect, in conftituting their ftate of fociety. Among thefe, the employments of the people, their manners and cuftoms, their religion, their government, their population, and the degree of freedom which they enjoy, will always be among the capital articles. A juft defcription of thefe, would afford a proper account of the tate of fociety, in this part of America. 
$312 \because$ THE NATURAL AND CIVIL

EMPLOYMENTS OP THE PEOPLE.

AGRICULTURE.-The body of the people in Vermont are engaged in agriculture. In a new country where the fettlements are yet to be made, agriculture puts on a very different appearance from that, which it bears in the ancient and well cultivated fettlements. There, the bufinefs is to cultivate and improve the farms, which have been already greatly improved: To increafe the produce, by the application of more labour and cultivation, and thus to derive a greater profit from the land. In a new fettlement, the firft bufinefs of the hulbaridman is to cut down the woods, to clear up the lands, to fow them with grain, to erect the neceffary buildings, and open the roads; and thus to connect and form a conmmunication between the fcattered fettlements, and make the moft of his labour.-Amidn the hard living and hard labour, that attends the forming a now fettlement, the fettler has the moft flattering profpects and encouragements. One hundred acres of land in a new town, does not generally coft him more than he can fpare from the wages of one or two years. Befides maintaining himfelf, the profits of his labour will generally enable a young man, in that period of time, to procure himfelf fuch a tract of land. - When he comes to apply his labour to his own land, the produce of it becomes extremely profitablc. The finft crop of wheat witl fully pay him for all the expenfe he has been at, in clearing ups forving, and fencing his land; and at the fame time, increales the value of the land, eight or ten times the original coft. In this way, erery day's labour fpent in clcaring up his land, rcceives ligh wages in the grain which it procures, and adds at the fame time a quantity of improved land to the farm. An acre. of laud which in its natural flate, colt him perhaps 
the half of one day's labour, is thus in one year made of that value, that it will afterwards annually produce him from fifteen to twenty five bufhels of wheat; 0 : other binds of produce, of equal value. In this way, the profits attending labour on a new fettlement; are the greatef that ever can take place in agriculcure: the labourer conftancly receiving double wages. Hé receives high wages in the produce of his corn of wheat ; and he receives much higher wages of another kind; in the annual addition of a new triet of cult tivated land to his farm. This double kind of wages; nature with great benevolence and defign; has affigned to the man of induftry, when he is firtt making a fettlement in the uncultivated parts of America: And in two or three years, he acquires a very comfortable and independent fubfiftence for a family, derived from no other fource but the earth, and his own induftry.

In every country, agriculture ought tó be efteems ed, as the moft neceffary and ufeful profeffion. The food and the raiment by which all orders of men are fupported, mult be derived from the earth. Agriculture is the art, by which this is effected; and of confequence the art which fupports, fupplies, and maintains all the reft. It ought therefore to be efreemed the primary; the fundamental, and the mort efrential art of all; that which deferves the firft and the greaceft confideration, and encouragement.The wealch drawn from agriculture, is permanent and durable; not fubject to the uncertainties attend: ing that, which is derived from commerce; and nos dependent upon the inclinations, the difpofitions; or the regulations of other kingdoms and countries. The people that thus live by their own agriculture, are independent of other nations, and need not be affected by their wars, revolutions, or convulifions; but may always have the means of fupport and inde.

$$
\text { Q q pendence, }
$$


pendence, among themfelves. While they have tha: which is drawn from the cultivation of the land, they will have every thing that nature and fociety can need, or have made valuable.

The other profeftions, thofe efpecially of the lib. eral arts, are of great utility, and of high importance, and they are what fociety could not flourifh without. But they derive their importance and utility from the imperfections of man, and of fociety ; and do not of themfelves, add any thing to the wealth of nations. The phyfician, the lawyer, the divine, the fatefman, and the philofopher, are engaged in einploymenis of great utility to mankmo. But there is not one of them, that adds any thing to the wealth and property of the community: They mun all derive :heir fupport, from the cultivation of the land. Of all arts and profeffions then, agriculture ought to be eftcemea the moft ufeful, and the molt important. It is the art which produceth, and nourithes all the sett. 'The other arts teach how to preferve the health, the property, and the morals of men; to enlarge their underftandings, and to give a right direction to their minds: But this provides food, rament, and lupport for them all,

In no way, has the glory of nations been more ex. panrled, than by their attainments and difcoveries in icience. The matnematicians have meafured, and fettled the dimentions of the folar fypens: But the new fetrles, has in fact, enlarged the bounds of the babicaule creation. The philofophers have expandecl our minds, with the ideas, and evidence, that the other planets are inhabited; but the fimple and honeft farmer, has macle the earth the place. for more in. habitants than it ever had before. And while the altronomers are fo juflly celebrating the difoveries, a.rd the new planet of Herfohel, all mankind thould rejoice, that the fimple peafant in the wildernefs, 
kas found out a vay, to make our planet bear more. men.

Thofe employments which are the mon neceffary, and the moft ufeful to men, feem to be the molt nearly connected with morality and virtue. Agriculture appears to be more nearly allied to this, than any of the arts. The man that is conftantly pirfuing the bufnefs, which nature has affigned io him, feems to have but little to corrupt him. In the many hifuries of corruption, there is not any account, that the body of the hufbandmen ever became a corrupt, venal, and debauched generation. They muft firn be led to defert their employments, or they mun be blinded and deceived, before they can be made fit tools for politicians to corrupt, and manage. Their profeffion tends to render thein an induftrious, hardy, incorrupted, and honeft fet of men. It is never in the body of the hufbandmen, but among the fpeculators, politicians, and leaders of mobs, that we look for a fettled trade, and high attainments, in venality and corruption.

MANUFACTURES. - Next to agriculture, the chief fource of employment is manufactures. Thefe are chiefly of the domeftic kind, defigned to procuse clothing for families. In no part of the United States, does the farmer meet with more luccels in raifing theep. The climate agrees well with the breed of theep, that is fpread over the territory: And the richnefs of the paftures, in new fettlements, gives an extraordinary fweetnefs to the meat, and richnefs to the fleece. It is not uncommon for a fheep of two or three years old to weigh one hundred and twenty pounds, and to afford three or fuur pounds of wool. And from the wool of their own raifing, the bigger part of the farmers manufacture the woolens, which are ufed in their families. In no places does flax fucceed better, than on the new lands. The commion produce from one acre, is

from 
from four to five bundred pounds. Every family raifes a quantity of flax, and carries on a fmall manufdcture of linen. Thefe domeftic manufactures, are of the higheft importance to the people. 'When the country fhall be well fettled, wool and flax will become two of its moft capital productions. At prefent, there is not enough of either annually pro. duced, to fupply the inhabitants.

Great advantages may be derived to the ftate, from the mamufactures of iros. Large quantities of iron ore are found in feveral of the cowns, on the weft fide of the green mountains. Tinmouth, Rit land, Pittsford, and Shoreham, contain great quantities. The ore in thefe towns is of a reddifh kind, mixed with eacth tinctured with yellow ore. It melts eafily, and produces from one feventh to one fourth of iron. The iron is moltly of the coldfhire kind, works eafily, and makes excellent nails. 'The principal part of the ore that has hitherto been ufed in this flate, has been brought from a mountain on the weft fide of Lake Champlain, about four miles north of Crown Point. This ore is of a black, heavy kind; moftly iron, mixed with a grey flintftone. The iron in this ore, appears in large grains, fome of them nearly as large as a pea: Ttsefe grains appear to be of pure iron. Some of this ore is fo peculiarly rich, that when it is well managed, it will yield four fevenths of pure iran; but is exceeding hard to melt. When the ore is well worked, it produces the beft iron for chains, horfe fhoes, nails, \&:c. and fuch matters as are drawn lengthways. When applied to ules which require plaiting widthways, it does not anfwer fo good a purpofe; though it is neither coldfhire, nor redhire. The fame kind of ore is found in many of the mountains, on the weft fide of the Lake, as far fouth as its waters extend.A country thus abounding with the richeft kirid of iron ore naturally invites the fettlers to the iron manufactures. 
manufactures. And they have already (1792) erected leveral forges, and furnaces. In Bennington county they have one forge; in Rutland county fourteen; in Addifon county four; and in Chittenden county two. In addition to which three furraces are allo erected, in the county of Rutland. From thefe works, large quantities of bar iron are annually produced. The manufacture of nails is already become common, and profitable; and every other branch of the iron manufacture, muft foon be fo.-Thefe manufactures, like every thing elfe in the new fettlements, are as yet in their infancy. But if we may judge from the plenty, or the eafe and cheapnefs, with which an immenfe quantity of the beft kind of iron ore may be procured, we fhall be apt to conclude that nature has defigned this part of the United States, to be the feat of very fluurifhing manufactures of every thing that can be made of iron, or fteel.

The manufacture of pot and pearl afoes, is Atill more extenfive, and ufeful. The immenle quantity of wood, with which the country is every where covered, may fupply any quantity of afhes for this purpole : And the greateft economy takes place in collecting the afhes, made either by culinary fires, o: thofe which are defigned to burn up the wood, where the inhabitants are clearing the lands. In al. moft every new fettlement, one of the firft attempts, is to erect works for the pot and pearl afh manufacture: And there are probably as many works of this kind, as there are fettled towns in the ftate. The bufinefs is every where well underftood; and there is no better pot or pearl afhes made in any part of America, than that which is produced in Vermont. It has hitherto taken fiom four hundred and fifty to four hundred ard eighty buthels of afhes, to make one ton of pot an. Conftant attempis are now made, to find out a way of extracling more of 
the falts from the afhes, than has been heretofore done by the common method of bleaching; and al. fo to extract more falts from the afhes, which have been thrown afide as ufelefs. Flattering profpects feem to have attended lome chymical experiments of this kind; and improvements have been made in the method of confructing the works for the pot afh. But much further improvements are neceffary, before thele imperfect attempts, can be of any very valuable ufe to the manufacturer. - The quantity of pot and pearl afhes, which is annually made in Ver. mont, cannot be exactly ftated. From the beft ac. counts I could procure, in the year 1.791 , the quantity might be eftimated at about one shouland tons: Probably this may be near the truth. But whatev. er may be the quantity produced at prefent, it is rapidly increafing; and probably will for feveral years, bear fome proportion to the increafe of the irihabitants. As the mountains will not fail to fup. ply wood for this manufacture, for centuries yet to come, it feems that Vermont will be one of the ftates, in which this manufacture will be attended with its greateft perfection and profit.

The manufacture of maple fugar is allo an article of great importance to the ftate. Perhaps two rhirds of the families are engaged in this bufinefs in the fpring, and they make more fugar than is ufed among the people. Confiderable quantities arecurried to the fhopkeepers; which always find a ready file, and good pay. - The bufinefs is now carried on, under the greateft difadvantages: Without proper conveniences, infiumerts, or works ; folely by the exertions of private families, in the woods, and without any orher conveniences than one or two iron kettles, the largeft of which will not hold more than four or five pailfulls. Underall the?e difadvantages, it is consmon for a family to make two or three hun-dred pounds of maple fugar, in three or four weeks. 
This manufacture is capable of great improvements. The country abounds with an immenfe number of the fugar maple trees. The largeft of thefe trees are five and an half or fix feet in diameter; and will yield five gallons of lap in one day; and from twelve to fiftecr pounds of fugar, during the feafon. The younger and fmaller trees afford fap or juice, in a fill greater proportion. Were the workmen furnithed with proper apparatus and works, to collect and boil the juice, the quantity of fugar might be increafed, during the time of making of it, in almol any proportion : And it might become an articlc of much importance, in the commerce of the countiy. - I have never tafted any better fugar, than what has been made from the maple, when it has been properiy refined; it has a peculiarly rich, falubious, and pleafant tafte. But it is generally made under fo many unfavourable circumftances, that it appears for the moft part, rough, coarfe, and dirty; and frequently burnt, fmoaky, or greafy, when it is firft made.- In one circumftance only, does nature feem to have fet bounds to this manufacture, and that is with refpect to time. It is only during four or five weeks in the fpring, that the juice can be collected. While the trees are frozen at night, and thawed in the day, the fap runs plentifully: But as foon as the buds come on, the fap ceafes to flow in fuch a manner, as that it can any longer be collected.-We cannot determine with much accuracy what quantity of this fugar is annually made in the ftate. In the town of Cavendifh, in the fpring of the year 1794, the quantity made by eighty three families, was fourteen thoufand and eighty pounds. If the families in the other towns manufacture in rhe fame proportion, there muft be above one thoufand tons annually made in Vermont.

Several diffilleries have of late been erected in this fate. The object of them is to make fuch fpirituous liquors. 
liquors, as can be extracted from grain. Confidering the large quantities of wheat, rye, and barlcy, that are raifed in the country, it feems probable that thefe diftillerics will foon be in a flournfhing ftate. Alt kinds of grain are raifed fo eafily upon our lands, and in fuch quantities, that the farmer can find no. fale, and has no ufe for them. They might immediately be raifed to double their prefent quantity, if there was any demand for them. The diftilleries have met with good fuccefs in their attempts to make gin. And nothing feems wanting, but time, and experience, to produce large quantities of all thofe fpirits, that can be produced from grain. As yet thefe wolks are in their infancy; probably they willbecome a lucrative branch of bufinefs to their own. ers, and of very confiderable advantage to the ftate.

HUNTING.- Hunting was formerly a bufmefs, which was much purfued, and attended with confiderable profit in this fate. The country, in its early. ftate, abounded with moofe, decr,' beats, foxes, wolves, rabbits, martins, \&c. In the lakes and creeks, there were large numbers of beaver, otter, mufkrats, and minks. The flefn of fome of thefe animals, and the furs of all of them, proved a lucrative branch of bufinefs to fome of the firft fettlers. But as the fettlements increafe, the wild animals difappear, and in a few years they will be fcarcely to be. found at all. At prefent the peltry may amount to one or two thoufand pounds per annum; but it has almolt ceafed to be attended with a profit, adequate to the expenfe.

Comarer.-Commercial concerns afford employment for a confiderable number of people. This branch of bufinefs is wholly confined to the adjacent parts of the country : Pait of it is carried on with Connecticat, part with Maffachufetts, a confiderable part with the province of Canada, but much the largen part with Newyork. The articles that. 
are brought into the ftate are chiefly rum, wines, brandy, and gin: Coarfe linens and woolens, and the various articles of cheap clothing: Tea, coffee, chocolate, and all the articles neceffary for building, which are not yet produced in the country. The exports are grain of all kinds, bar iron, and nails : Pot and pearl alhes; beef, pork, live cattle, horles ; lumber, peltry, fome flax, and maple fugar.-The amount of the commerce of an inland country, cannot be very accurately afcertained; nor have we any way to de. termine, what quantity of goods are annually brought into the ftate; or to what value, the remittances an nually amount. - The trade itfelf has been of great advantage, in promoting the fettlement of the country; but the carriage of the articles, being chiefly by land, and through long and bad roads, has been attended with great expenfe; and has much prevented the raifing of wheat, and other kinds of grain. The natural channels into which the trade of Vet. mont will refolve itfelf, will be a water carriage upon Conneeticut river; and through Lake Champlain, down the rivers of Hudfon, and St. Lawrence. As vigorous attempts are now making, to render all thefe waters better fuited to the purpofes of navigation, the time cannot be far diftant, when commerce thall be more eafily carried on, become much ir. creafed, and be attended with much greater advan. tages to the ftate.

In any of thefe employments, the labourer has the profpect of acquiring not only a very comfortable living, but fufficient property to maintain a family. The price of labour will always bear a proportion to the profits it will produce, and to the demand which there is for it. In a new country every on: that can perform a day's work, will find employment in any part of the country. In agriculture, the labourer can procure feventy dollars a year for his work; equal in value to one hundred and twen- 
ty bufhels of wheat. In the bufy feafons of the year, the common price of a day's labour is half a dollar; in winter not more than half this fum. All kinds of labour are in the ufual proportion to that of agriculture.-Of thefe wages it will take twenty dollars, to procure comfortable clothing; the remainder the Jabourer is able to referve for other purpoles. Thus by labouring for another for two or three years, the labourer becomes independent, and works afterwards upon his own land or flock.

The writers upon political economy in Europe, are confantly mentioning the great advantages which accrue to trade and cummerec, from an extreme cheapnefs of labour. The beneficial effects that would arife frorn it in America, would be no compenfation for the diladvantages that would attend it. It would not be any advantage to the country, to carry on any branch of bufinefs, which would not fupport itfelf, and pay well for the labour. Leaft of all would it be of any public benefit, to have the profits of the labour of many, centre in the hands of a few wealthy' men. This would reduce the body of the people to poverty, dependence, and venality; and introduce all that endlefs confufion of laws for the fuppert of the poor, which has perplexed all the wealthy parts of Europe, for more than a century. Thofe laws, with their perpetual alterations, plainly denote that the difficulty does not admit any remedy from the ordinary courfe of law. - In every country, in which the fate of fociety is fuch, that the labourers have the profpect and the hope of acquiring property, that body of men are as active, enterrrifing, and economical, as any other order in-the fate. Take from them, ander any pretence, the proper profits of labour, and all profpect and hope of acquiring eafe and property by it, and the European confequences will follow : The poor will every where abound, the weallhy muft maintain them, and both 
both will be diffatisfied: Speculators will be per. petually propofing new laws, and the more the laws are multiplied, the worfe will be the condition of the poor, and the greater will be the expenfe of the rich. This will be the unavoidable confequence, when the wealth of a nation has prifed into the hands of a few men: Or when the body of the workmen, infread of labouring upon their own property, continue to ferve under a mafter. 


\section{H A P. XIII.}

State of Societr.-Cufroms and Manters: Education, early Marriages, AEtivity, Equality, Eccisomy, ana' Hofpitality of tbe People.

THE cuftoms and manners of nations are derived from defcent, fituation, employment, and all thofe regulations which have an influence upon the fate of the people; and they ferve better than other circumftances to afcertain the character of nations, and to denote the ftate of fociety at any given period in their hiftory.- The cuftoms and manners of the people of Vermont, are principally derived from the people of Newengland, from whom they are defcended: But in a few particulars they have received a direction, from the fate of fociety which takes place among the fettlers in a new country.

EDUCATION-Among the cuftoms which are univerfal among the people, in all parts of the nate, one that feems worthy of remark, is, the attention that is paid to the education of children. The aim of the parent, is not fo much to have his children acquainted with the liberal arts and fciences; but to have them all taught to read with eafe and proprie. ty; to write a plain and legible hand; and to have them acquaintes with the rules of arithmetic, fo far as flatl be necelfary to carry on any of the molt common and neceffary occupations of life. All the chil. dren are trained up to this kind of knowledge : They 
are accuftomed from their earlieft years to read the Holy Scriptures, the periodical publications, newfpapers, and political pamphlets; to form fome general acquaintance with the laws of their country, the pro. ceedings of the courts of juftice, of the general affernbly of the ftate, and of the Congrefs, \&rc. Such a kind of edúcation is common and univerfal in every part of the ftate: And nothing would be more difhonourable to the parents, or to the children, than to be without it. One of the firft things the new fetticrs attend to, is to procure a fchoolmafter to inAtruct their children in the arts of reading, writing, and arithmetic: And where they are not able to procure or to hire an inftructor, the parents attend to it themfelves. No greater misfortune could attend a child, than to arrive at manhood unable to read, write, and keep [mall accounts: He is viewed as un. fit for the common bufinefs of the towns and plantations, and in a fate greatly inferiour to his neighbours. Every confideration joins to prevent fo degraded and mortifying a ftate, by giving to every one the cuftomary education, and advantages. - This cuftom was derived from the people of Newengland: and has acquired greater force in the new fettlements, where the people are apprehenfive their children will have lefs advantages, and of confequence, not appear equal to the children in the older towns. No culom was ever better adapted to private, or public good. Such kind of education and knowledge, is of more advantage to mankind, than all the fpeculations, dilputes, and diftinctions, that metaphy ics, logic, and fcholaflic theology, have ever produced. In the plain common good fenfe, promoted by the one, virtue, utility, freedom, and public hap. pine s, lave their foundations. In the ufelefs fpeculations produced by the other, common fenfe is loft, folly becomes refined, and the ufeful branches of knowledge are darkened, and forgot.

EARLY 
EARLY MARRIAGES.-Another cuftom, which every thing tends to introduce in a new country, is early marriage. Trained up to a regular induftry and economy the young people grow up to maturt. $t y$, in all the vigour of health, and bloom of natural beauty. Not enervated by idlenels, weakened by Inxury, or corrupted by debauchery, the inclinations of nature are directed towards their proper objects, at an early period; and affume the direction, which nature and lociety defigned they thould have. The eafe with which a family may be maintained, and the withes of parerits to fee their children fettled in the way of virtue, reputation, and felicity, are circumftances, which allo frongly invite to an early fertlement in life. The virtuous affections are not corrupted nor retarded by the pride of families, the ambition of oftentation, or the idle notions of ufelefs and dangerous diftinctions, under the name of honour and titles. Neither parents nor children have any other prolpects, than what are founded upon induftry, economy, and virtue. - Where every circumflance thus concurs to promote early marriages, the praftice becomes univerfal, and it generally takes place, as foon as the laws of fociety fuppofe the young people of fufficient age and difcretion to tranfact the bufinels of life.-It is not necelfary to enumerate the many advantages, that arife from this cuftom of early marriages. They comprehend all that focicty can receive from this fource; from the prefervation, and increafe of the human race. ' $\mathrm{Ev}$. erv 1 hing ufeful and beneficial to man, feems to be connected with obedience to the laws of his nature: And where the ftate of fociety coincides with the Juws of nature, the inclinations, the duties, and the bappinefs of individuals, refolve themfelver into curtoms and habits, favourable, in the higheft degree, so lociecy. In no cafe is this more apparent, thatr? in the culoms of nations refpecting marriage. When wealth, 
wealth, or the imaginary honour of families, is the great object, marriage becomes a matter of trade, pride, and form; in which affection, virtue, and happinefs, are not confulted; from which the parties derive no felicity, and lociety receives no advantage. But where nature leads the way, all the lovely train of virtues, domeflic happinefs, and the greateft of all public benefits, a rapid population, are found to be the fruit.

Activity and ENTERPRize.-A fpirit of activity and enterprize is every where found in a new ftate. Depending upon their own induftry, and having nothing to expect from fpeculation and gaming in public funds, or from the errors or vices of government, the views of the people are directed to their own employments and bufinefs, as the only probable method of acquiring fubfiftence, and eftate. Hence arifes a fpirit of univerfal activity, and enterprize in bufinefs. No other purfuits or profpects are fuffered to divert their attention; for there is nothing to be acquired in any other way. Neither begging, or gaming, or trading upon public funds, meafures, and management, can be profitable emiployments to the people who live at a diftance from wealthy cities, and the feat of government. The only profitable bufinefs, is to purfue their own pro. feffion and calling. - To this purfuit their views become directed; and here, their activity and enterprize become remarlsable. No difficulty or hard. thip feem to difcourage them: And the perfeverance of a few years generally ferves to overcome the ob. ftacles, that lay in their way at firft. It is only thofe who are of this enterprifing fpirit, who venture to try their fortunes in the woods; and in a few years, it generally raifes them into eafy and comfortable circumftances. - To the moft effential and neceffary ulutics of man, heaven has annexed immediate and important bieffings, The people thus active, labo- 
rious, and perpetually in hard exertions, are deffitute of many of the conveniences of life; and of what, in every populous city, would be efteemed its neceffaries. Can their health and fpirits remain unimpaired, arnidnt this fcene of hard living, and. hard labour? Will they not wafte away thus labour. ing in the woods, without good living, able phyf. cians, and the advantages of medicine? So far fiom it, that no people have fo few difeafes, multiply fo faft, or fuffer fo little from ficknels. Temperance and labour do more for them, than art and medicine can do for others. The diforders which wear away the inhabitants of wealthy cities, are almolt unknown in the woods. Very few die, but under the una. voidable decays of nature; and the deaths are to the births, in no higher a proportion than 1 to 4,8. Unacquainted with the improvements which are made in the medical art in Europe, the people of the new fettlements neither know the nanes of the difeafes, or their remedies; nor ftand in any need of their difcoveries, or prefcriptions. The benevolent Author of Nature has annexed that health to their temperance, induftry, and activity, which is never found in drugs, medicincs, or any attainments of art. And while the people are thus aclive and induntrous in performing their duty, the property and health of individuals, and the profperity of the ftate, are all found to flourifh togsther.

EQUALITY. - The neareft equality that ever can take place among-rnen, will alfo be found among the inbabitants of a new country. When a number of snen are engaged in the fame err.ployments and purfuits, and have all of them to depend upon tincir own labour and induftry for their fupport, their fituation, vicws; and inanners, will be nearly the fame; the way to fubfiftence, to eale, and independence, being the fame to all. In this flage of fociety the neareft equality with take place, that ever can futfift among crear. 
then. But this equality will be nothing more that an equality of rights; and a fimilarity of employment, fituation, purfuit, and intereft. In a new country this fimilarity will be fo great, as to form a near refemblance of manners and character; and to prevent any very great inequalities of privilege from taking place in fociety; either from rank; offices of government, or any other caufe.-But nothing ever did, or ever can produce an equality of power, capacity, and advantages, in the focial, or in any other tate of man. By making men very unequal in their powers and capacities, nature has effectually prevented this. The whole race refemble one another in the make and form of their bodies ; in their original appetites, paffions; and inclinations ; in reafon; underftanding, and the moral fenfe, \&zc. But in thefe refpects it is fimilitude, not equality, which nature has produced. To fome, the Author of Nature has affigned fuperiour powers of the mind, a ftrength of reafon and difcernment; a capacity of judging, and a genius for invention, which are not given to others. To others; the Deity has affigned a ftrength; vigour, and firmnels of conftitution, by which the bodily powers are more favoured in one, than in ar. cther. Caules thus natural and original, will be followed with their natural and proper effeets. Superiour wifdom and abilities, will have fuperiour influence and effect in fociety. Superiour ftrength and activity of body, will alfo have advantages peculiar to themfelves. In making thefe naturai diftinctions, nature evidently defigned to qualify men for different attainments, and employments. And while the gave to all the nature and the rights of man, fhe affigned to fome a capacity and a power, to make a much more uieful improvement and exrcile of that nature, and of thole rights, than he hiss given tn others. - Thus a fate of noture is itfelf a Rate of Cociety, or at lea? naturally tcrads to produce

$$
s i
$$


it. And in the earlieft ftages of fociety, all thas equality will take place among mankind, which is confiftent with it. Placed in a fituation nearly fimilar, the employments, views, and purfuits of the people, become nearly the fame. The difinctions derived from birth, blood, hereditary titles and honours, and a difference of rights and privileges, are either unknown or refolve themfelves into nothing, among a people in fuch a fituation ; in every vicw, they ceafe to be of any ufe or importance to them. Their ficuasion naturally leads them to difcern the teridencies, and defigns of nature. They all fest that nature has made them equal in refpect to their rights; or rather that nature has given to them a common and an equal right to liberty, to property, and to fafety; to juftice, government, laws, religion, and freedom. They all fee that nature has made them very uneçual in refpect to their original pow. ers; capacities, and talents. They become united in claiming and in preferving the equality, which nature has affigned to them; and in availing themfelves of the benefits, which are defigned, and may be de. ived from the inequality, which nature has alfo efmblifhed. Wherever a number of people are engaged in a common, economical, laborious purfuit of fubfiftence, property, and fecurity; fuch views of their cquality, and rights, inmediately occur to their minds; they are eafly difcerned, and they are perfectly well underftood.

ECONOMY.-Every thing in the fituation and employments of the people, in a new country, will saturally tend to produce economy. There are no Jargc eftates, or cultivated farms, prepared beforehand for the heir. Every thing for food, raiment, and convenience, mult be procured by the labour and induftry of the planter; and it is not without much diffrcul'ty, and hardnip, that the people can procure the neceffaries of life at firn, or the conve- 
riences of it afterwards. What is thus procured with labour and difficulty, will be ufed with prudence and ecosiomy. The cuftom will not be to fall into fcenes of expenfive entertainments, amufement, and diffipation : But to provide for the calls and demands of nature, to preferve the health and vigour of the body, and to be able to raife up and fupport a family. And this will of courfe, introduce a fteady regard to economy, in all their expenfes, habits, and cultoms. - The influence that this has on the affairs of individuals, and on the ftate of focicty, is every where apparent. No fuch degrees of wealth can ever exift in any place, as thall be equal to the demands of luxury. And where cultom has introduced a habit of living asd expenfe, above the annual income, dependence, venality, and corruption, with conftant want and diftrefs, is the never failing confequence. But the moft pernicious of all the effects of luxury, is the degradation it brings on the nature of man. It deftroys the vigour and powers of men, and by conftantly enfeeb: ling the body and mind, feems to reduce them to a lower order of beings. The body, weakened by exceffive indolence and indulgence, lofes health, vigour, and beauty, and becomes fubject to a thoufand emaciating pains and maladies. The mind, fubdued by indolence and inactivity, fcarcely retains its rational powers; and becomes weak, larguid, and incapable of manly exertions, or attainments. Toa ftate thus degraded, effeminate, and unmanly, lux. ury frequently reduces thofe, who bear the remains of the human form. Political writers have frequently argued that luxury was of real fervice to the nations of Europe ; that it tended to find employments for the poor, and was neceffary to keep the money in circulation. This reafoning cannot be contradicted : But it fuppofes the ftate of fociety to be effentially bad; and that it cannot be fupported but 
by the inanagement, operations, and balance of xices. In fuch a ftate of fociety, luxury is certainly a benefit: And the higheft degree of it, would be the greateft benefit of all. It would be the bef thing that could happen in fuch a fociety, for the corrupted venal part to fpend their eftates, by luxury and diffipation, and to have them pafs into oth. er hands. This would be far better for mankind than to have them live ufelefs, be confantly corrupting others, or train up an emaciated feeble race, degraded by effeminacy and weaknels, below the reft of the human race. Whatever might be done to load fuch with honours, titles, and diftincsions, it swill be impoffible ever to make them men; or at leaft fuch kind of men, as thall be upon terms of equality with the reft of the human race. - A Etivity, induftry, and economy, will prevent fuch a race from appearing, or fuch effects from taling place, in any of the new ftatcs of America.

Hospitality. - That benevolent friendly difpofition, which man fhould bear to man, will ap. pear under different forms, in diffcrent ftages of fo. ciety. In the firft combinations of mankind, when all are expofed to danger, fufferings, and want, it appears in one of its molt amiable forms, and has been called hofpitality. In this form it exilts among the people who are fubjected to the common danger, fatigue, and fufferings, which attend the forming of new fettlements. Feeling every moment their own wants and dangers, they are led by their fituation, to affit each other in their difficulties and danger. The traveller finds among them, all the relief their circumftances will enable them to afford him: And before they are able to ereet houfes for public entertainment, the ftrarger is fure to find the beft accommodations, the fituation of private families will admit. - This hofpitable difpofition feems to be univerfal, in all the new fettlements : And the unfortunate 
unfortunate and poor man finds a relief from it, which he never cxpeds to find among a more wealthy poople. No custom was ever better adapted to afford relief to an individual, or to promore the advantage of the ftate. A beggar or robber is fearcely ever to be feen in a country, where thure is nothing to be obtained by the bufinels. The poor find their retief in labour, and not from a multiplicity of laws, which extract large furns from others, but afford litile relief $t o$ them: And from the profits of their labour, they will foon ceafe to be in diftrefs. Thofe that appear to be objects of dittrefs, are generally fuch in reality: And where the public has not been abufed by fuch pretences, fers will be expoled to luffer on fuch accounts. In fuch a ftate of fociety, hofpitality naturally performs what it ought to perform : It encourages none in idlenels and difipation, but relieves thofe whofe circuirftances require relief. It provides only for thofe, who cannot find other refources; and aims only to put fuch into a fituation, in which they may fupport themielves, and be of ule to the public. 


\section{H A P. XIV.}

STAтE or Socrety.-Religion: Imporlance of this Principle, Danger of any Controul in it, Equality of all Denominations, Effect of this Equality, Grants and Laws for the Support of Religion, Extent of Religious Liberty, Connexion of Religion with Science and Education.

ReLigion is one of thole con. cerns, which will always have great influence upon the ftate of fociety. In our original frame and conftitution, the Benevolent Author of our Natures, has made us rational and accountable creatures: Accountable to ourfelves, to our fellow men, and to our God. Thefe foundations of religion, are fo Atrong, and univerfal, that they will not fail to have an effect upon the conduct of every one : And while they thus enter into the feelings and conduct of all the members, they will unavoidably have a great influence upon the ftate and conduct of focicty. Nor can fociety either fet them afide, or carry on the public bufnefs without them. Inftead of this, in one form or another, fociety will be perpetually calling in the aids of religion. When human declarations and evidence are to receive their higheft force, and moft folemn form, or when the mon important tranfactions are to be performed, and offiees of the higheft truft and confequence are committed 
mitted to men, the laft appeal will be to religion, in the form of folemn affirmation or oath.

The molt pure and benevolent fyftem of religion, which has ever prevailed among men, is that of Chriftianity. This religion founded in truth, and adapted to the nature and ftate of man, has propored for its end and aim, that which is of the higheft importance to men and to fociety, univerfal benevolence, the love of God and man, or univerfal virtue. But neither this, nor any other fyftem of moral truth, can impart infallibility to men. Whatever infallibility there may be in moral, in mathematical, or in revealed traths, men may greatly miftake when they come to explain, and apply them : And inftead of being above all poffibility of error, they will find that infallibility belongs only to the government of God; and that it certainly is not ensailed upon any parties, or denominations of men.Fothing therefore could be more dangerous, than to allow to any of thefe denominations the power to make laws to bind the reft, in matters of religion. The ruling party would vote themfelves to be the only pure denomination, they would make the reft contribute to their fupport, and eftablifh their own fentiments and practice, as the perfection of knowledge, wifdom, and religion; and in this way adope meafures, which tend to entail all their imperfections and errors, upon future ages. The dominion of one party over another in matters of religion, has always had this effect: It has operated to confirm error, opprefs the minority, prevent the fpirit of free inquiry and inveftigation; and fubjected men to the moft unrelenting of all perfecutions, the perfecution of priefts and zealots, pleading principle to juftify their vileft actions. - At the fame time, every good man feels himfelf bound not to renew or ad. nit any fuch authority in matters of religion. The obligations of religion are antecedent to, and more frong. 
frong than any obligations derived from the laws of fociety. The firft and the inoft important obligation any man can feel, is to obey his Maker, and the ditates of his own heart. The peace of our minds depends more effentially upon this, than any other circumftance in the courfe of human life. - What then luas fociety to do in matters of religion, bus fimply to follow the laws of nature: To adopt thefe, and no other; and to leave to every man a full and perfect liberty, to follow the dictates of his own confcience, in all his tranfactions with his Maker?

The pcople of Vermont have adopted this principle, in its fullelt extent. Some of them are epifcopalians, others are congregationalifts, others are of the prefbyterian, and others are of the baptift per. fuafion; and fome are quakers. All of them find their need of the affitance of each other, in the common concerns and bufinefs of life; and all of them are perfuaded, that the government has nothing to do with their particular and diftinguifhing tenets.-It is not barely toleration, but equality, which the people aim at. Toleration implies either a power or a right in one party, to bear with the other; and feems to fuppofe, that the governing party are in poffeftion of the truth, and that all the others are full of crrors. Such a toleraticn is the moft that can be obtained by the minority, in any nation, where the majority affume the right and the powcr, to bind fociety, by eftablifhed laws and forms in religion. The body of the people in this commonwealth, carry their ideas of religious liberty much further than this: That no party fhall have any power to make laws or forms to oblige another that each denomination may lay themfelves under what civil contracts and obligations they pleafe; but shat government fhall not make any dittinctions be sween them; that all denominations fhall enjoy eqqual 
equal liberty, without any legal diftinction or preeminence whatever.

The effect of this religious freedom, is peace, quiernefs, and profperity to the ftate. No man is chofen to, or excluded from civil offices, on account of his particular religious rentiments. The clergy of the feveral denominations, have no chance to affume any powers, but among their own party. The people are under no obligation to fupport any teach ers, but what they choofe to lay themfelves under. And no civil advantages are to be gained, or lont, by belonging to one denomination, rather than to another. The caufes and the motives to contention, being thus talsen away, there is fcarcely any thing left to infuence men to join one denomination rather than another, but belief, fentiment, and confcience. In this equality of all parties, religious profelfiors become what they always ought to be; no: matters of gain, profit, or civil diftinctions; but matters of opinion, perfuafion, and confcience : Ser ziments and faith refpecting the Deity, in which none expect to find the power of oppreffing or ruling over ochers; but the fame protection and benefit from the government, which they are at equal expenfe in fupporting.

The fettlement and fupport of the minifters of religion, has been encouraged and affifted by the government. The earlieft granis of land in this ftate, were made by Benning Wentworth, governor of Newhampthire. This gentleman vas of the communion of the church of England. In the grants of land that ricie made by him, there were inree rights in each townhip referved for religious purpoles: One to the fociety for propagating the gofpel in foreign parts; one for a glebe, defigned for the vie of an epifcopal clergy ; a third for the firte feteled winifter, incended for tis private propersy, to en-

$$
\text { I't courage }
$$


courage the fettlement of a minifter in the new pian tations. In the grants of townfhips, which have beenmade by the government of Vermont, two rights have been referved for the fupport of a clergy : One for a parlonage, defigned for the fupport of a minifter, and unalienable from that purpofe; anoth. er to become the property, and defigned to encourage the fettlement of the firft minitter. This right accrues to the firt clergyman who is fettled in the town, of whacever denomination he may be. - The falary of the minifter arifeth wholly from the contract which the people may make with him. There contracts are altogether voluntary : But when made, by a law paffed Oetober 18, 1787, are confidered âs being of equal force and obligation as any other contraets; büt no perfons of a different denomination are obliged by them. The law has no reference io any particular denomination, but confiders them all as having a right to make what contracts they pleafe, with the minifter they choofe; and being of courfe bound by their own act, to fulfil their contiact. A law defigned to confirm the equal rights of all, is not fubject to the exceptions or complaints of any party.

No embarraffments have attended any of the grants of land, which have been made for religious purpofes, but thofe defigned for a glebe, and thofe made to the fociety for propagating the gofpel in foreign parts. In moft of the towns there are not any perfons of the epifcopal perfuafion, nor any incumbent to have the care of the glebe lots. The fociety for propagating the gofpel in foreign parts, have not concerned themfelves about the lands, which were granted to them. Both thefe rights have 5.mained unimproved and unculcivated, except where individuals have gained poffefion of them; and is has been a difadvantage to the Rate, to have fuch tracts of iand lying warte. It has been repeatedly a 
matter of confideration in the general affembly, what ought to be done with thefe lands. - Inftead of coming to any decifion upon the matter, in OEtober, 1787 , the general affembly paffed an act, authorifing the felectmen of the feveral towns, to take case of and improve the glebe and fociery lands, for the fpace of feven years; and to apply the incones to the in. provements of the lands, thofe excepted, which were in the poffeffion of an epifcopal minifter. This law has been but little attended to, and is not at all com. petent to the improvement of the lands, or to render them beneficial to the ftace, or to any valusble purpole. - In any view of the marter, thele lands ought not to be fuffered to remain ufelers, and derrimental. to the ftate. If the fociety for propagating the grofpel in foreign parts, had made fuch an afignation of them, as would have ferved to promote religious inftruction and knowledge, the people would have had the benefit that was intended by the grantor. If this be neglected an unreafonable time, it becomes the duty of the legillature, to prevent their remaining a public difadvantage to the ftate, by continuing uncultivated and ufelefs.

The principles of religious liberty, are afferted in their fulleft extent, in the conftitution of Vermont. In the declaration of rights, there is a claufe which reems to be adequate to the fubject, and clearly expreffes the religious rights of the people. - "Nor can any man be juftly deprived or abridged of any civil right as a citizen, on account of his religious fentiments, or peculiar mode of religious worhip ; and no authority can, or oughe to be vefted in, or affumed by any power whatever, that fhall in any cafe interfere with, or in any manner controul the rights of confcience, in the free exercife of religious worthip." In the plan of gorern'nent formed in

* Declaration of rights, Article III,

1778 , 
$177^{8}$, and revifed in 1786 , a religious teft was im. poled upon the members of the aflembly, inconfiftent with the above declaration: In the late revifal of the conftitution (1792) this imperfection has been done away; and religious liberty has acquired a complete eltablifhment, by a declaration that " no religious tent thall be reguiled of any member of the legiflature."*

A greater attention to the liberal arts and [ciences, would be of great advantage to the religious and civil interefts of the thate. The people of $V \mathrm{er}$. mont have not the advantages for the education of their youth, or the improvement of knowled ", which the people in the other ttates have. The difadvantages and dangers, which arife for want of literary inftitutions, are greater than they are arvare of. The religion of ignorance, will either be, infị. delity, or fuperftition; and it often produces an unnatural mixture of both, greatly unfavourable to the inoral, and civil interefts of men. TVhen folly, in its own view, is become infallible and facred, it oppofes with obftinacy, all improvements in fociety; and requires, with a peculiar infolence, the fubmiffion of all other men, to its own weaknefs and big. otry. The only remedy for the difficulties which arife in fociety, from this caufe, is the increale of knowledge and education. And where fociety is deftitute of the means and inftitutions, which are requifite to promote knowledge, it is without one of its moft effential advantages; the nears of her own cultivation, and improvement.

The education of children for the common buf. nefs of life, is well attended to. But the cuftomary methods of education for the profeffions of divinity, law, or phyfic, are extremely deficient; and do not promife either eminence, or improvement. The

* Plan ar frame of government, Section $V$. 


\section{HISTORY OF VERMONT.}

body of the people appear to be more fenfible of this defect, than profeffional men themfelves. From the firft alfumntion of the powers of government, the alfembly had in contemplation, the eftablifhment of an univerfity in the fate; and with this view, referved one right of land in all the townfhips which they granted, lor the ule of fuch a feminary. In Novernber, 1791, the legiflature pafled an act eftab. lifhing the univerfity at Burlington, upon a liberal, catholic, and judicious foundation. It has not as yer, entered upon the bufinels of inftruction. If it thould be furnithed with able and judicious inftructors, by extending the benefits of education, and promoting an attention to the arts and fciences, it would greatly affit the intellectual and moral improvement of the people : Thefe improvements are of effential importance to men, in every ftage of fociety; but moft of all neceffary, when they are forming a new hate. 


\section{C $\mathrm{H}$ A P. XV.}

State of Society.-Nature of the American Gov. ernment. Conftitution of Vermont, Laws, Counties and Courts, Annual Expense of Government, Public Revenue, Militic, Popularity of the Government.

Nature of thr Amer.
ican Government. The object and the principle of government is the fame, in cvery part of the United States of America. The end or the defign of it, is the public bufinefs; not the power, the emolument, or the dignity, of the perfons employed, but only that public bufnefs which concerns either the whole federal territory, or fome particular thate.-The principle on which all the American governments are founded, is reprefentation. They do not admit of fovereignty, nobility, or any kind of hereditary powers; but only of powers granted by the pecple, afcertained by written conftitutions, and exerciled by reprefentation for a given time.

Governments founded on this principle, do not necefrarily imply the fame form. They do not ad. mit of monarchy, or ariftocracy; nor do they admit of what was called democracy by the ancients. In the ancient democracies the public bufinefs was tranfacted in the affemblies of the people: The whole body affembled to judge and decide, upon public affairs. Upon this account, the ancient democracies were found to be unfit, and inadequate to the government of a large nation. In America this difficulty 
difficulty never occurs: All is tranfacted by reprefentation. Whatever may be the number of the people, or the extent of the territory, reprefentation is proportioned to it; and thus becomes expreffive of the public fentiment, in every part of the union. Hence the government in different fates, though chiefly republican, varies in its form; committing more or lefs power to a governor, fenate, or houfe of reprefentatives, as the circumftances of any particular ftate may require. As each of thefe branches derivc their whole power from the people, are accountable to them for the ufe and excrcife they make of it, and may be difplaced by the election of others; the fecurity of the people is derived not from the nice ideal application of checks, ballances, and mechanical powers, among the different parts of the government; but from the refponfibility, and dependence of each part of the government, upon the - people.

This kind of government feems to have had its form and origin, from nature. It is not derived: from any of the hiftories of the ancient republics. It is not borrowed from Greece, Rome, or Carthage. Nor does it appear that a government founded in reprefentation ever was adopted among the ancients, under any form whatever.-Reprefentation thus unknown to the ancients, was gradually introduced into Europe by her monarchs; not with any defign to favour the rights of the people, but as the beft means that they could devife to raife money. The monarchs who thus introduced it, with a view to collect money from the people, always took care to check it when it ventured to examine the origin and extent of the privileges of the fovereign, or of the rights of the people. - In America every thing tended to introduce, and to complete the fy ftem of reprefentation. Made equal in their rights by nature, the body of the people were in a fituation nearly 
fimilar with regard to their employments, purfuits, and views. Without the diflinctions of titles, fain. ilies, or nobility, they acknowledged and reverenced only thofe cliftinctions which nature had made, in a diverfity of talents, abilities, and virtues. There were no family interefts, connexions, or eftates, large enough to opprefs them. There was no exceffive wealth in the hands of a few, fufficient to cor rupt them. Britain tried in vain to force upon them a government, at firft, derived from the decrees of her parliament ; afterwards, from conqueft. Nothing remained for fuch a people, but to follow what nature taught; and as they were too numerous to attempt to carry on their governments in the form of the ancient democracies, they naturally adnpted the fyftem of reprefentation: Every where choofing reprefentatives, and affigning to them fuch powers as their circumftances required. This was evidently the fyltem of government, that nature pointed out : And it is a fy ftem that has no where been fuffered to prevail but in America, and what the people were naturally lead to by the fituation, in which Providence had placed them. The fyftem of government then in America, is not derived from fuperNition, conqueft, military power, or a pretended compact between the rulers and the people; but it was derived from nature, and reafon; and is founded in the nature, capacities, and powers, which God hath alligned to the race of men.

All the power that fuch governments can have, is derived from the public opinion. 'The body of the people while they remain indufrious and economical, will be fteadily attached to the public intereft, which will entirely coincide with their own. They will more readily difcern what their intereft is, and? be more fleadily attacher $10 \mathrm{i}$, than is to fe cxpeet. ed from men who are placed in offices of hozour and profit. The public opinion will be much near. 
6: the truth, than the reafonings and refinements of fpeculative or interefted men: The former will be tounded wholly in a defire, and aim, to promote the public fafety; the latter will be unavoidably more or lefs governed, by private views, interefts $s_{i}$ and aims: And when the government has the general opinion of the people to fupport it, it can act with the greateft force and power; that is, with the collected force and power of the whole nation: And this is the greateft. force that ever can be exerted by any government, in any fituation whatever.-Defpotifm never acquires a force equal to this. When a whole nation unite, and the public fpirit moves and operates in the fame direction, nothing can with tand its force, and the powers of defpotifm, with all their ftanding troops and regular armies, fall before it. It is only when the public fentiment and fpirit is thus uniced, and brought into action, that government has acquircd, or is able to exert the whole force of the national power.-With this ftrength, the governments of America amidnt every kind of difficulty; role fuperiour to all oppofition; firmly eftablifhed themfelves, in fifteen different ftates; and gave uncomznon vigour and efficacy to a federal eftablifhmens, which was defigned and adapted to manage the pub. lic bufinefs of the whole fyfern.

But whatever be the form or the power of gov. ernment, it cannot attain its greateft perfeEtion, un. lefs it contains within itfelf, the means of its own improvement. The men of civilized countries, are making gradual and conftant improvements in knowl. edge, in the fciences, and in all the arts by which lifes is made more fecure and happy. Hence, that form of government which was beft fuited to their thate in one Rage of fociety, ceales to be fo, in another: And unlefis the governirent itfelf in proves, with the gradual-improvement of fociety, it will lore much of its refpectability, and power; become unfuited to

$$
\text { L? a }
$$


the ftate, and injurious to the people. Defpetifm has always contemplated the body of the people, as mere mob; and has aimed and operated to keep them in that fituation. To governments founded in this principle, the improvement of mankind proves fatal and deflructive: And there is nothing, fuch governments are more anxious to prevent, than knowledge, property, and improvement, in the body of the people.-Built upon the rational and focial nature of man, the American government expects to find its fureft fupport, and greatef duration, in the gradual improvement, in the encreafing knowl. edge, virtue, and freedom, of the human race. The prefent government of America, is therefore propoled to her citizers, not as the moft perfect ftandard: of what man can ever attain to, but only as the beft form, which we have as yet been able to difcover: Not as a form, which is to bind our heirs and pofterity forever, but as a form which is referred to them, to alter and improve, as they Thall find bett. Up. on this idea, it is one of the conftituent and effential parts of American government, that conventions fhall be called at certain periods of time, to alter, amend, and improve the prefent form and conftitution of governinent; as the ftate, circumftances, and improvements of fociety, fhall then require. Thus provifion is made, that the improvement of government, fhall keep pace with the improvement of foeiety in America. And no policy would appear more puerile or contemptible to the people of America, than an attempt to bind polterity to ous forms, or to confine them to our degrees of knorvledge, and improvement: The aim is altogether the severfe, to make provifion for the perpetual improvement and progreffion of the government itfelf.

As this kind of government is not the fame as that, which has been called momarchy, arinocracy; or democracy; as it had a confpicuous origin in America. 
snd has not been fuffered to prevail in any other part .of the globe, it would be no more than juft and prop. er, to diftinguifh it by its proper name, and call it, Tbe American Syfers of Government.

Constitution OF VRRMONT. - The government of Vermont is of the fame nature, and found:ed upon the fame principles, as the other govern. ments in the United States. By their conftitution; formed in 1778 , and revifed in 1786 , and 1792 , the fupreme legiflative power is vefted in a houle of reprefentatives of the freemen. Every town has a right to choofe a reprefentative, on the firft Tuefday of September annually. The reprefentatives to chofen, are to meet on the fecond Thurlday of the fucceding October, and are fnyled Tbe General Afjersbly of the ßlate of Vermom. They have power to choole their own officers; to fit on their own adjouruments ; prepare bills, and enact them into laws; they may expel members, but not for caules known to their confituents antecedent to their election; irpeach ftate criminals; grant charters of incorporation, con. Atitute towns, boroughs, cities, and counties; in conjunction with the council they are annually to elekt judges of the fupreme, county, and probate conrts, fheriffs and juftices of the peace; and alfo with the council, may elect majorgenerals, and brigadiergenerals, as often as there thall be occafion: They have all other powers neceffary for the legiflature of a free and fovereign fate: But have no power to add to, alter, abolifh, or infringe any part of the conflitution.

The fupreme executive power is vefted in a governor, or lieutenantgovernor, and a council of twelve perfons, cholen by the freemen, at the fanie time they choole their reprefentative. The governor, $\alpha$ t the lieutenantgovernor and council, are to commif. flon all officers; prepare fuch bufinefs as may ap. pear to them neceffary to lay before the general af fembly: 
fembly: They are to fit as judges to hear and de. ter:nine on impeachments, taking to their alfillance, for advice only, the judges of the fupreme court. They have power to grant pardons, and remit fines, in all cales whatloever, except in treafon and murder, in which they have power to grant reprieves, but not to Dardon until after the end of the next feffion of afembly, and in cales of impeachment; in which there is no remiffion or mitigation of punifhment, but by act of legiflation. They may alfo lay embargoes, or prolibit the exportation of any commocity, for any time not exceeding thirty days, in the recefs of the houle only. - The governor is captaingeneral and commander in chief of the forces of the ftate, but thall not command in perfon, except advifed thereto by the council, and then only fo long as they thall approve: And the lieutenantgovemor by virtue of his office, is lieutenantgeneral of all the forces of the flate.

That the laws before they are enacted may ba more maturely confidered, and the inconvenience of hafty determinations as much as poffible prevented, all bills which originate in the affembly are laid before the governor and council for their revifion and concurrence, or propofals of amendment; who return the fame to the allembly with their propolals of amendment (if any) in writing; and if the fame are not agreed to by the affembly, it is in the power of the governor and council, to fufpend the paffing of fuch bills, until the next feflion of the legillature. But no negative is allowed to the governor and council.

The formers of the conflitution were aware that the plan of government, which they had drawn up, would not be adequate to the affairs of government, when the ftate of the people fhould become different, but muft neceffarily vary with it : $\Lambda$ nd they wifely made provifion to have the whole examined 
end revifed, at the end of every feven years. The provifion they made for this purpole was a council of cenfors, to confint of thirteen perfons, to be elected by the people every feventh year, on the laft Wednefday in March; and to aflembie on the firft Wednelday in June. The duty afingned to them, is to inquire whether the conflitution has been preferved inviolate in every part; whether the leginlative and executive branches of government have performed their duty, as guardians of the people; or affumed to themfelves, o: exercifed other or greater, powers, than they are entitled to by the confitution; whether the public taxcs have been jufly laid, and collected; in what manner the public monies have been difpofed of ; and whether the laws have been duly executed. Powers fully competent to thefe purpoles, are committed to them. They may fend for perfons, papers, and records: They have alz thority to pals public cenfures, to order impeachments, and to recommend to the legiflature the repealing fuch laws, as thall appear to them to have been enacted contrary to the principles of the confitution. Thefe powers they may exercife during the fpace of one year, from the time of their election; and they may call a convention to meet within two years after their fitting, if they judge it neceffary. In examining a conflitution of government, the mont capital circumftance to be taken into confideration, is, the condition and circumftances of the people, or the ftate of lociety among them. At the firft aflumption of government in Vermont, the form of it differed but little from tha democracy of the ancients. From that period, it has been conftantly tending to give more power to the houfe of reprefentatives. - But it is found by experience, that in fo popular a government, nothing is more neceffary than fome provifion, like that of the council of cenSors, to have all the public proceedings revifed at 
certain periods of time; and fuch alterations made in the conftitution, as time, events, or the circumftances of the people, may rcquire. As the fate of fociety is progreffive, there is no way to have the government adapted to the fate of fociety, but to have the government alfo progreffive; that both snay admit of the improvements, that are gradually made in human affairs. With-this provifion, a conftitution of government which contains many faults, will gradually mend and improve itfelf, without being forced to the dangers and convulfions of a revolution: And it feems to be the only provifion which human wifdom has yet found, to prevent the interpofition of fuch calamities.

2. IA ws. - So much of the common law of England as is not repugnant to the conftitution, or to any aहt of the legiflature, is adopted as law within this fite: And fuch ftatute laws, and parts of laws of the kingdom of England and Greatbritain, as were palfed before the firft day of October, 1760 , for the explanation of the common law, and are not repugnant to the conflitution, or forne act of the legiflature, and are applicable to the circumftances of the ftate, are alfo adopted and made law in Vermont. - The criminal law of Greatbritain feems to be adapted only to a very degraded, vicious, and barbarous ftate of fociety. No lefs than one hundred and fixty crimes are punifhable by death. Sanguinary laws and executions have there made death fo common and familiar, that it feems to have become one of thofe common nccurrences, which is conftantly to be expected, and is very little regarded. Several of the purifhments, in the contrivances of their cruelsy, are fully equal to any thing that has ever been perpetrated by the Indians of America : In brutal xage and inhuman torture, the punifhment affigned to high treafon, fairly exceeds any thing the Indian genius could ever conceive. - Such a code of crimie 
nal law is wholly unfitted to the uncorrupted ftate of the people in America; nor would they in any part of the continent, be perfuaded to admit it. Inftead of one hundred and fixty there are only nine crimes, to which the laws of Vermont have affigned the punifhment of death : And fince the firft affumption of government in 1777, there has not been any perfon convicted of any of thefe crimes.WW hat relates to the internal affairs of government, the regulations neceffary for a new country, or fuck as are fuited to our particular ftate of fociety, are provided for by ftatutes made for fuch particular cafes and purpofes. - To form a code of laws fuited to the ftate of a large nation, has been juftly efteemed the moft difficult part of government. It does sot appear that human wifdom has ever been able to effeet this without great errors, in any part of the earth. If it is to be obtained, the particular ftates of America have now a fair opportunity to make the experiment, how far human wifdom can proceed at prefent, in effecting this arduous but molt important attainment.

Counties ANd Courts.-For the more convenient adminiftration of juftice, the ftate is divided into eleven counties; viz.

Counties.

Bennington,

Windbam,

Windfor,

Rutland,

Drange,

Addifor,

Chitiendies,

Caledonia.

EJjex.

Franklin.

Orjeans.
County Torens.

$\{$ Bennington.

$\{$ Manchefter.

Newfane.

Windfor.

$\{$ Woodftock,

Rutland.

Newbury

Middlebury.

Burlington。 
In the four lat countics, courts are not to be holden until the firt day of October, 1796 . In the other counties there are probate courts, juntices" courts, county courts, a fupreme court, and a court of chancery.

The juftices of peace in each county are annually nominated, and appointed by the general affembly : They are of courfe the fame perfons, as the mem. bers of the affembly from each county, with the addition of a few others. They have power to try and determine all pleas and actions of a criminal nature, where the fines and forfeitures are within the fum of forty fhillings, and the corporal punifhsnent fhall not exceed ten ftripes. They may alfo try and determine all pleas and actions of a civil nature (other than actions of defamation, repicin, trefpars upon the freehold, and where the title of land is concerned) where the debt, and other matter in demand, does not exceed the fum of four pounds; and alfo determine on all fpecialties, notes of hand, and fettled accounts, not exceeding the fum of eighe pounds. They may allo bind over to be tried by the county or fupreme court, all criminal offenders, the enormity of whofe mildemeanor furpafs therr power to try: No judgment rendered by a jufice. of peace, can be reverfed by writ of error : But appeals are allowed to the ncxt county court, in all cafes where the judgment for debt or damages, fhall cxcced the fum of forty fhillings.

In each county there is alfo a county court; con. finting of three judges, who are alfo annually ap. pointed by the affenbly. The county courts, within their refpective comnties, are to take cognizance of all criminal matters of every name and nature (except fuch cales as are cogrizable on!y in the fujreme court, or before a jullice of the peace) and award fentence. But any perfón profecuted for a rriminal offence, may appeal from the judgenent of 
t county court, to the next fupreme court: All actions and caufes of actions of a civil nature (except fuch actions as are made cognizable folely before the fupreme court, or juftices of the peace) muft $b$ : originally commenced, and profecuted to effect in z county court:

The fupreme court of judicature confifts of three judges; to be annually chofen by ballot, by the governor, council, and general affembly, at their October feffion. This court has cognizance of all pleas of the ftate, criminal actions and caufes, and what loever relates to the confervation of the peace, and punithment of offenders; and alfo of civil caufes or actions between party and party, and between the ftate and any of its fubjects, whether the fame be brought into faid court by appeal, writ of error, or in any other legal way whatfoever. The fupreme court has original exclufive jurifdiction of the crimes of adultery, polygamy, and all capital felonies, of treafon, mifprifon of treafon, counterfeiting the currencies of the Itate; and every fpecies of forgery, perjury, fubordination of perjury, incelt, rapes, de faming the civil authority of the ftate, and all other crimes and mildemeanors, where a fine or penalty is going to the ftate treafury, or where the punifhment extends, either by common or ftatute law; to the lofs of life, limb, or banifhment. - The fupreme court begins their circuit in Bennington county, on the firft Tuefday in Augult: From thence is proceeds to Rutland, the next adjacent county; beginning the feffion there on the fecond Tuefday in fuguft; and in this order proceeds through all the counties in the ftate, beginning the feffion in the rext county, on the fucceeding Tuefdays, until they have finifhed the circuit in feven weeks at Windhain county : And it is left to the chief juftice, to call a fpecial court, where the exigencies of government thall require it. 
A court of chancery is alfo conftituted in the fat of Vermont; to be holden in the feveral counties within the ftate, at the feveral times and places appointed by law for holding the fupreme court of judicature. The judges of the fupreme court, are conflituted judges or chancellors of the court of chancery. They hare all the powers, ufually exercifed by that court in the kingdom of Greatbritain, and in the neighbouring ftates, and not repugnant to the conttitution. The manner of procefs in this court, is to be governed and regulated by the judges; conforming, as near as may be, to the rules and precedents eftablifhed in the courts of chancery, in the kingdom of $G$ reatbritain.

Annual Expense of Government. - The annual expenfe of the government is generally about thirty two or thirty three hundred pounds. In the year $179^{2}$, the feveral articles of it were thefe,

The governor's falary.

Lieuteran:governor's fees for at-7 tending council, fifteen fhillings per day.

Counfellors' fees for attending council, feven thillings per day.

Reprefentatives' fees for attending the general affembly, fix fhillings per day.

Secretary of Atate's fees for attend. ing the general affembly, twelve fhillings per day.

Secretary of council's fees for attending the council, nine Thilings per day.

Officers attending the general affernbly, theriff, anditor of accounts, chaplain, \&c. fix thillings per day. $f_{0} \cdot 15000$ $119^{6} 90$ 
Chief juftice of the fupreme court, while on the circuit, one pound feven thillings per day.

Two affiftant judges, one pound 130560 two fhillings per day; orders drawn on the treafury by the fupreme court.

Treafurer's falary.

Occafional expenfes. Orders drawn 11800 on the treafury, by the auditor of accounts.

Total expenfe from Otober 1, 791 , to October 1,1792 .

$449 \quad 149$ $6.3,219 \quad 99$

Thefe are the conftant and annual experfes atteriding the government, and do not greatly differ in different years: But as the number of reprefentatives is annually increafing, the public expenfe is annually increafing on that account. There are other expenfes which arife almoft every year, which are of an occafional, and contingent nature. Of this kind are commifioners for public purpofes, the council of cenfors, conventions \&c. As thefe are only for fome particular or occafional purpofe, the expenfe varies with the occafion; and they cannot be eftimated among the annual charges of government.The whole expenfe then of government, from October, 1791, to October, 1792, amounted to three thoufand two hundred and nineteen pounds, nine Rillings, and nine pence. If this fum be divided among the inhabitants of the ftate, as determined by the cenfus taken in 1791, it will amount to but nine pence, or the eighth part of a dollar, for each perfon. This is the fum that each perfon in Vermont pays for the protection of his perfon, property, and the advantages of a free government. I believe there is not any part of the civilized world, in which the inhabitants enjoy the bleffings of government, at fo fmall an expenfe. 
PUBLIC REVENUE. - The revenue of the fate arifeth wholly from the public taxes. For fome time after Vermont had affumed the powers of government, very confiderable revenues arofe from the unappropriated lands: But as thefe lands are almoft all appropriated, no further incomes can be derived from this fource. Commerce, in an inland country, can never be attended with any confidera. ble revenue. "The only fource that can be found, is taxation.- In the year 1791, the whole lift of the taxable property of the ftate, amounted to $f \cdot 3^{2} 4,7961810$. The prices at which the lifters were directed to eftimate the improved lands, and cattle, were fcarcely one half of the current prices of thofe articles: The eftimate therefore in the lift, could not amount to one half of the real value of. the rateable property of the fate. After making an abatement upon this lift of $f, 1,1168$ o for the twofolds, a tax was voted of two pence half penny, upon the pound; amounting to $f_{0} \cdot 3,37 \times 140$. The expenfe of collecting this rate, allowed by law as fees to the collector, is a fiftieth part: And a further abatement is made for the benefit of the poor, of a twentieth pa!t. Thefe abatements being deducted, the fum the government receives is $6 \cdot 3,135140$. With the addition of $f_{0} .83$ to this fmall fum, was the whole expenfe of government, among eighty fix thoufand perfons, defrayed in the year 179?. If this be compared with the expenfe of government in Europe, the difference will be found to be infinite: The babe of a monarch, will colt a nation there, thirty or forty times this fum.

It ought alfo to be recorded, for the benefit and remembrance of the people of America. For this is the place, where a corruption in government, always makes its firlt appearance. Reafons and caufes are eafily found, to increafe the number of public places and offices: And thole who are in power, and 
and derive their living from the public, will compute the honour and dignity of the government, by the fums of public money which are allowed to them. The progrefs has ever been certain, gradual, and regular; from fmall beginnings, to the utmoft extreme of luxury and diffipation, that the national wealth could fupply. It would be almoft a miracle, if public affairs thould not atrume the fame afpect and couife, in America. If it is prevented, it will not be by government: It can alone be done by the virtue, the knowledge, the economy, and the public fentiment of the people.

MILITIA. - The military force of the ftate conGifts of all the able bodicd males, from fixteen to forty five years of age; with fuch exceptions as are cuftomary in the other ftates. The men are required by law to provide themfelves with fuch arms as are ufed in times of war, when in actual fervice. They are divided into companies, regiments, brigades, and divifions. The companies elect their captains, and fubalterns. The captains and fubalterns appoint the field officers of their refpective regiments. The brigadiergenerals, and the majorgenerals, are appointed by the governor, council, and houfe of reprefentatives. The governor is captaingeneral and commander in chief, and with the advice of council, is to arrange the whole militia into divifions, and brigades; and may from time to time, make luch alterations as he thall think fit. The whole militia of the ftate, is to be reviewed at leaft once in two years.

In $179^{2}$, the flate of the militia was as follows : Twenty regiments of infantry, divided into eight brigades, and four divifions: Fifteen companies of cavalry, and fix companies of artillery; the whole computed at eighteen thoufand, five hundred.

The ftaff confilts of one captaingeneral, one lieutenantgeneral, four majorgenerals, eight brigadier.

generals $s_{8}$ 
generals, one adjutantgeneral, and one commiffarygeneral.

The militia of Vermont are a body of brave, hardy, robutt, and intrepid men. Trained up to hardihip, labour, economy, and hunting, they have all the qualifications that tend to fit men for the military character: Difcipline and actual fervice, tranfforms them at once, into a body of excellent troops. In the American war, there were no better troops collected from any part of Europe, or America, than the regiments raifed in Vermont. The moft brave, hardy, and robult militia, will always be found among the inhabizants of new countries.

Popularity of the Government.-From the experience the people have had, of the influence and operation of the government, they are not only fatiffied with it, but they are very ftrongly attached to it. This is the fureft way to judge of all theories, forms, and conftitutions of government. What is written upon paper refpecting government, is no otherwife good or bad, than as it is applicable to mankind, and may be beneficial, or difadvantageous to them. While government feryes to promote the benefit and profperity of the people, the people will be attached so it. But when the body of the people become difcontented and uneafy, it may be prefumed, there is fome capital error, or vice in the government. - During a century and an half, every part of America, was under the controul of the kings of Europe. The minifters of the European courts were perpetually interfering in the affairs of the colonies, and were perfuaded that the colonifts had not wifdom enough to govern themfelves. Through the whole of this period, all thofe parts of America flourifhed the moft, in which the European monarchs intermeddled the leaft : And there was not one fpot on the contirient, athere the inhabitants were not better qualified to 
gorern themfelves, than the wifeft minifter of ftate in Europe. The one, perfectly well underftood their own fituation, circumftances, dangers, and interefts ; and were attached to the welfare of the country: The ocher, were almoft wholly ignorant of the ftate of things in America; and not at all difpofed to pro. mote her intereft, any further, than as it ferved to advance the intereft of the crown, under which they ferved. This muft always be the cafe, where one people are in fo unhappy and unnatural a fituation, as to be under the government of another. - The people of America have now no reftraint, no oppofite incereft of a foreign king, and parliament, to perplex. their government, influence their meafures, and oppofe their intereft. They have every where fet up governments for themfelves; and they are every where flourifhing, and rapidly increafing in their wealth, and numbers: And are not only fatisfied, but they are ftrongly attached to their governments. If there be any certain marks of a good government, thofe marks are the peace, happinefs, and profperity, the increale, and the affections of the people. 
$3^{60}$ TH. NATURAL AND CIVIL

\section{H A P. XVd.}

State of Society.-Population: Caufes on wbicto this depends, the mean Period of Human Life in the American States, Period of doubling in Vermokt. comparative View of Population in new and old Countries.

Population depends upon two general caufes, the original laws of nature, and the ftate of fociety. - In the original confitution of animals, the Author of Nature has eftablifhed certain laws refpecting their increafe, and multiplication, which cannot be exceeded. Thefe laws relate chiefIy to the age at which the female becomes capable of bearing fruit, the numbers that may be produced at one birth, the time that muft intervene between one birth and another, and the age at which the female will ceafe to be prolific. The laws of nature refpe日ing each of thefe particulars, confidered with refpect to the human race, are much affected by climate; and are every where fubject to univer fal and conftant obfervation. But they are fo far from being accurately known, or afcertained, that whoever fhall attempt to make a computation upon either, or all of them, will find that not one of thefe periods has been maiked by oblcrvation; and that the mean period required by nature for thefe purpofes, is $y$ t: mnknown in cvery country and climate. 
The increafe of mankind, thus confined within certain limits by nature, is alfo very much affected by the ftate of fociety. The condition of the body of the people, the eafe or the difficulty with which they can procure property to maintain a family, the genius of the civil government, the fpirit and regulations of religion, the numbers employed and the deftruction occafioned by war, the inflitutions of celibacy, with the manners and cuftoms of the people, may retard or favour population, to a great de. gree; and caufe it to be very different in the fane climate, and at the fame place, at different times. Both the fe caufes generally combine, and operate together; and in fuch a manner, that we cannot leparate their effects; or determine how much is to be afcribed to the law of nature and climate, and what is derived from the ftate of fociety. This difficulty attends all the tables which have been made of births, deaths, and marriages. Tables of this kind have been made for almoft every nation in Europe, and for feveral places in America. They appear to have been the refult of accurate obfervations and calculation. But the refults at different places in the fame latitude and climate, have been fo different, that no general conclufions can be drawn from them, refpecting the natural increafe of the human race: They mark what has taken place at a given time, and place; but they afford little information of what is to be expected, from the general courfe of nature, in any particular country, or climate.

By the late enumeration of the inhabitants of the United States of America, a period has been found in the courfe of human life, above, and below which the number of the males are nearly equal. This period is nearly at the age of fixteen years. Can we not derive come information, from fo remarkable a fact, refpecting the increafe and population of the people of the United States? And may it not be deternined what

$$
\mathrm{X} \times \text { muft }
$$


mult be the operation of nature, to produce and preferve this equality of numbers, below, and above that age?

Let us atternpt to compute it upon a given cafe. Suppofe the whole number of people in one of the fiates of America, amounted to thirty two thoufand; one half of which had not attained the age of $/ \mathrm{f} x$ tecn, and the other half had paffed this period. At the end of fixteen years, the whole number will have pafled the mean period, and be found in that number whote age is above fixteen, making togethEr thisty two thoufand. - To ballance this number, muture muft have produced in the fame time, an equal number whole age will be below fixteen : That is, cluring this period of fratecn years, thirty two thrutand inut have been born. For everyone then that has paffed the period of fixteen years, mature mutt have produced two; otherwite the ballatece, oran equality in the numbers below and aborts that nre, coulu not be preferved. And this would allo be the exact period of doubling the number of the inhabitants.

This mirt be the operation of nature, if the fubject on whom the calculation was made, had been invariable, or lubject to no diminution. But this is unt the cale. Death is conthantly diminifhing the number of thofe whofe age is above fixteen, of thofe whole ang is below fixteen; and it diminilhes them bo:h, in the lame proportion. This curious fact is afcertained by a courfe of obfervations, made in fevcral towns in the eaftern parts of Newhamplhire. At Hampion an accurate table of deaths, with the arye of cach perfon, was lept by the mininers of the purifh, from the year, 1735 to 1791 . Similar bills were kept at Eoftkingfton, from 1740 to 1771 : At Newriarket, from 1731 to 1770 : At Dover, from 1767 to $1786 \%$ The refult of thefe obfervations is, * Belknap's HiR, of Newhamphire, III. P. $238-248$, 
is, that the whole number which died in thole towns, during thofe years, was two thoufand and nimety cight: Of thefe, one thoufand and fifty were under fixteen years of age, and one thouland and forty eight above that age. In the refult of to long a courfe of obfervations, made in four different towns, we may expect to find the regular courfe of nature, or the natural operation of death, well afrertained. And they feem fully to have eftablifhed this curious fact, That death has an equal effeck, or is connantly deftroying equal numbers of thofe whole age is above, and of thofe whofe age is below fixtcen years.

Such is the operation and effect of death: And by conftantly diminifhing the numbers of mankind, it will every where prolong the period of deubling. beyond the mean period of human life. But to what degree will it retard this event; or to what length of time will it prolong the period of doub. ling? It will prolong the period of doubling, exately in that ratio, which the deaths fhall bear to the births, in the fame period of time.-The bills which were kept in Newhamphire, do not contain an accurate account of the births, but only of the baptilms; and therefore will not ferve to difcorer what proportion the deaths bear to the birtbs, in thole towns. But from the bills of mortality, which have been kept in Maffachufetts, it has been found that the number of deaths, are anrually in a confant. and fettled ratio to the number of births. At Hingbam, the aged and venerable Dr. Gay, kept a very exact lift of all the deaths and births in his parifi, for the fpace of fifty four years; from 1726 to 1779 . inclufive. The deaths amounted to one thouland one hundred and thirteen, the births to lwo thoufand two hundred and forty feven. At Ip fwich, the Rev. Dr. Culler, made fimilar obfervations for a courfe of ten years, from Sept. 11, 177 1 , to Sept. 11, 1781 , The number of deaths were one hundred 
and fixty four, the number of births three hundred and thirty one.* At Salem, an accurate and able phylician and philofopher, C. A. Holyoke, M. D. has given an exact bill for the years 1782 , and 1783 : The deaths were three hundred and fixty four, and the births feven hundred and two.t In thefe num. bers we have the refult of a courle of abfervations carried on in three different places, during a period of fixty fix years. The refult of the whole, is, that the deaths were one thoufand fix hundred and forty one, and the births amounted to three thoufand two hundred and eighty; that is, the deaths were to the births in the ratio of one to two. This is the annu. al and conftant proportion of death to birth, in the ancient towns, along the fea coft, in Maffachufetts. The increafe of the people therefore derived from the births, is annually diminithed one half by the natural operation of death: And infead of doubling in fixteen years as muft have been the cafe had no one died, the effect occafioned by death, will be, to prolong this period one half; inftead of fixteen years the period of doubling will become twenty four. This will be the period of doubling in all thofe places, wisere the mean age of human life is fixteen years, and the ratio of death to birth as one to two.

From this method of reafoning, I much lufpect that the age at which the numbers of people are $e$. qually divided, will in every country prove to be the time, which nature requires in that climate, to produce double the number of people that are then iiving: That the actual period of doubling, will in fact be retarded in exact proportion to that, which the deaths bear to the births: And that this ratio will very nearly determine what influence the ftate of fociety has, on the increafe of mankind in any country or town.

* Memoirs of American Academy, Vol. I. p. 566.

+1 kid. 543 . 
I am not in polfeffion of the data that would be neceffary to examine this theory, by the nate of things in the ancient and populous countries, of the orher hemilphere. But from the enumeration that was made of the inhabitants of the United States of America in 1790 , we may venture to compute the thate of things among ourfelves. - The number of males, their relative proportions, and the age at which the numbers below and above fixteen become equal, are as.follows:

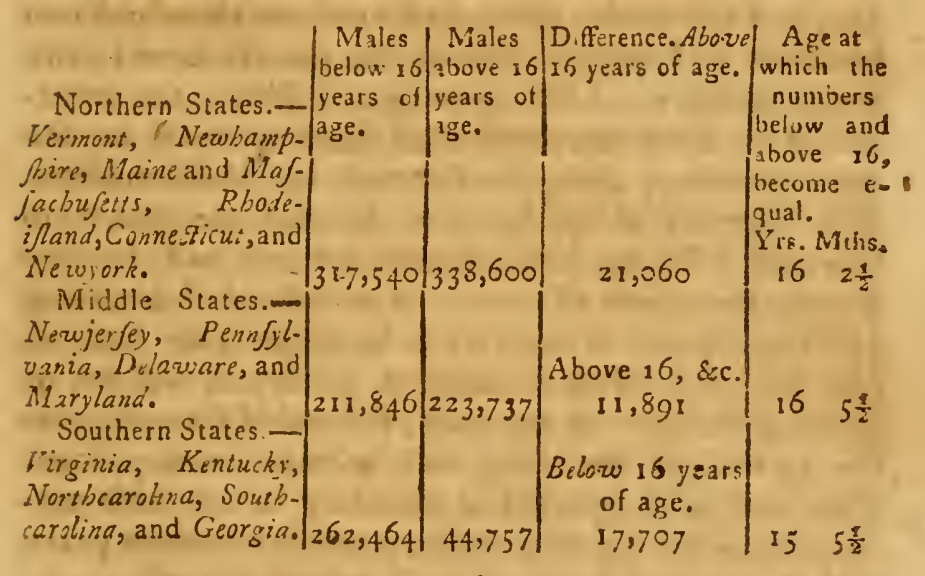

From this view of the refult, it fhould feem that the middle and northern flates were the mof $f_{d}=$ vourable to longevity, and the prefervation of life: And that the fouthern ftates were the molt favourable to a rapidity of production, and increafe. Whether thefe circunflanees will not ballance each other, and produce an equality in the period of doubling cannot be determined without further obfervations. In Maffacbufetts, the period of doubling cannot be far from twenty four years and three months. What this period is in the other ftates, muft be determined either from actual obfervation, or by afcertaining the ratio which the deaths bear to the births. If the enumeration which is to be taken in the year 1800, 
1800 , fhould be as particular with refpect to the females, as the laft was with refpect to the males, it would enable us to afcertain feveral particulars in this part of the natural hiftory of man, which cannot be determined without another enumeration.

It has been generally fuppofed, that the increale of mankind is moft of all rapid, in a new country ; and that it is in the new fettlements, that nature acts with the greateft force and vigour. Vermont is now in the fituation, in which a new country uught to be examined. We have no populous towns, feaports, or large manufactories, to collect the people together. They are fpread over the whole country, forming fmall and feparate fettlements. Agriculture is almoft the univerfal employment. Bat few are pinched for want of the neceffaries of life, and nothing like lursury has yet taken place among us. The government is highly democratic. In religion the moft perfect freedom and equality takes place among all parties. The taxes are no rhore than what are unavoidably necelfary, to preferve the exiftence and form of government. Lands are eafy to be procured, and the foil is rich and fertile. - Every family enjoys nearly the whole produce of their labour. The climate is falubrious and healthy. And neither war, ficknefs, or famine, have of late diminifhed the increafe, or difurbed the la. bours of the people.-I do not know that we can find any new country, in which, every circumftance feems more favourable to increafe: Or any, in which we may more probably expect to find the maximum, which nature and fociety can produce in fuch a latitude and climate. - From the enumesation of the inhabitants taken in 1791, we have the following refult : 


\section{HISTORY OF VERMONT.}

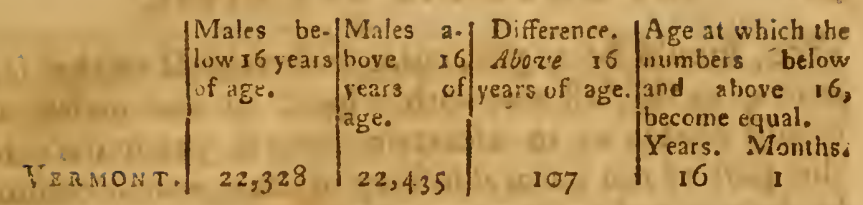

To afcertain the effect produced by the natural operation of deach, I have procured a bill of mortality for one of the principal towns, for the years 1.789.90, and 91. It is made for Rutlend, from the oblervations of $E$. Porter, and D. Recd, two able phyficians.

Number of inhabitarits Deaths. Births. Ratio of the Period of doubling in Rutland in $179 \mathrm{r}$.

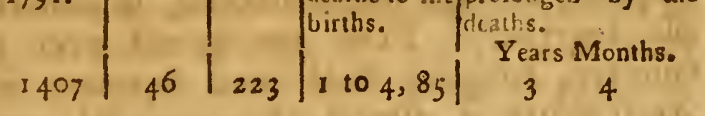

From this table it appears that the deaths in Vermont, are to the births, in the porportion of 1 to 4,85 ; of confequence the period of doubling in this ftate, at prefent, is nineteen years and five months.*

From fuch views of the increafe and population in America, we can fcarcely avoid comparing the ftate of things in the United States, with that of the ancient and populous countries in Europe. In the city of London, if we may judge from the annual bills of mortality, the human race are annually decreafing; the deaths generally exceed the births, about one tenth every year. The favage ftate was lefs unfavourable to the increafe of mankind, than fuch large and populous cities : Inftead of preferving, they tend to defroy the human race.

In molt of the ancient and populous nations of Europe, their forms of government, their ecclefraftical

* Since writing the above I have received from Dr. Afaph Fletcher, an accurate obferver and able phyfician, an account of the births and deaths in the town of Cavendifs. In the courfe of feven years the number of births in that town was iwo hundred and ten; the number that died in the fame $p e$. rod, was thirty. - The rasio of deaths to that of births in tha: :own, during this period, has been but as one to feven, 
tical eftablifhments, the extreme luxury of one part of the people, and the extreme poverty of the other, their long and bloody wars, their numerous fleets and armies, the numbers which are reduced to fervitude, and rendered incapable of fupporting families, with the impious inftitutions of celibacy, have nearly deftroyed the natural increafe of mankind; or at leaft they have rendered it extremely flow, and uncertain. "In Greatbritain, and moft other European countries, they are not fuppofed to double in lefs than five hundred years." *-In vain do politicians go about to celebrate the wifdom of a ftate of fociety, which deftroys the nobleft fruit and production of nature : It muft be effentially, and fundamentally bad. The fureft proof of the profperity of any country, is a rapid increafe of the people.

* Smith's wealth of nations, Vol. I. 94 . 


\section{H A P. XVII.}

State or Societr. - Freedom: Defroyed in fome Countries by the State of Society, produced by the Selvlement of America, the Cauje and Effect of the American $W$ ar, cannot be preferved by Government, depends on the State and Condition of the People.

\section{THE employments, the government,} the religion, the cuftoms, habits, manners, and condition of the people, conftitute their ftate of fociety. In the ftate of fociety which had taken place in America, the foundations of her freedom were laid, long before the nations of Europe had any fufpicion of what was taking place in the minds of men.-Conqueft, religion, law, cuftom, habits, and manners, confirmed by military power, had eftablithed a fate of fociety in Furope, in which the rights of men were ob. literated and excluded. The property and power of a nation had paffed into the hands of the fovereign, nobility and church. The body of the people were without property, or any chance or profpect of fecuring any ; and without education or knowledge to fortn them to any rational principles and fentiments. Without property and without principle, they wete of little or no confequence, in the view of government. When the conteft was whether the king or the commons hould gain more pow er, the meaning was not at all whether the body of the people thould be railed out of their degraded Yy

itatc 
ftate of ignorance, poverty, and infignificance; bue whether that part of the nation, which had acquired much wealth and property, thould have more influence in the affairs of government. The body of the people were efteemed as mere mob, wholly inadequate and unfit for the affairs of government. The king, lords, and commons, were agreed in viewing the mafs of the people in this light. And as they had neither property, principle, or knowledge, it is probable that the opinion which their rulers formed of them, was but too juit.

Such had been the flate of fociety in Europe, for many centuries. Time, law, religion, and power, had combined with every other circumftance, to degrade the people; and to reduce the body of them to the lowent ftate of abafement, and contempt. - In a flate of fociety, in which every thing had fo long deviated from the defign and law of nature, it could not be, but that the rights of men fhould be loft; and the idea of them had nearly perifhed. Nothing was to be feen but one general degradation of the body of the people, and an unnatural and exceffre exaltation of thole who bad acquired power; every where tending to corrupt both, and to give the muft unfavourable idea of the capacity of the former, and of the difpofition of the latter. It required the daring fpirit of Milton and Sydncy, and the abilities of Locke and Montefquieu, to dilcover the rights of men, when men themfelves for many centuries, had made the fate of fociety wholly oppofite and contraly to the ftate of nature. The philofopher had to deduce them from the creation, and nature of man. In this inquiry, the progrefs, like dilcoveries in other fciences, was extremely flow and precarious. Intereft and reputation were againft the progrefs of this kind of knowledge. The law, the chuich, and the government, were not only oppofed to it, but they punilied the difcoverers and writers, by whipping, 
ping, imprifonments, heavy fines, and death. None but the greateft and molt virtuous of men, were either able to inveftigate, or 'would' dare to affert what belonged to the nature of man, and what was derived from the nature of fociety.

In America, every thing had affumed a different tendency and operation. The firft fettlers of the colonies, had fuffered fevcrely under the bigotry and intolerance of ecclefiaftical power, in the days of Elizabeth, James, and Charles the firtt. They had not at firft, any more knowledge of the rights of human nature than their neighbours, and they were as far from the fpirit of candour and toleration. But when they were expoled to fevere fufferings on account of their religion, they were placed in a fitua. tion, in which their feelings would perform for them, what their reafon had not acquired fufficient force to effect. They felt, and of courfe faw, that there was no reafon or righteoufnels in the punifhments which were inflicted upon them, on account of their religion. In fuch a fituation, truth occurred to them every moment; and their fituation and fufferings effectually taught them, what were the rights of men : They could at once difcern and undertand the voice of nature, which had no effect upon thofe in power, and probably would have had more upon them, had they been in the fame ftate. - IV ith thefe views they came into America. Situation and employment immediately operated to enlarge and con. firm the fentiments which their fufferings had firf produced. The wildernefs was to be cleared up, habitations were to be built, the means of living were to be procured: Thefe occupations were fo necelrary, that they became unavoidable; and every man who did not mean to perifh, was obliged to engage in them. This fimilarity of fituation and employment, produced a fimilarity of ftate and condition; at that time, unknown to the reft of the world: The 
effects of which the firft fettlers did not at all comprehend, themlelves. The bigger part of them reverenced monarchy, as a facred inftitution of heaven ; but they felt at the fame time that the honours and dillinctions it produced, were of no avail to them. To be wife, ftrong, indufrious, and healthy, to have rulers, judges, and generals, the diftinctions which nature urged, they found to be of the highen importance. But to be called a duke, an earl, or a marquis, the difinctions which fociety had let up againit nature, they found could be of no importance to them, and denoted nothing valuable in themfelves. Nothing was left for them but to purfue the line and courfe of nature, which was that of utility and fafety. And this could produce nothing but fimilarity of fituation, rights, privileges, and freedom. Every new fettlement, was a confirmation of the fame ftate of fociety; and notwithftanding the per. petual interference of royal authority, every thing operated to produce that natural, eafy, independent fituation, and fpirit, in which the body of the people were found, when the American war came on.-In fuch circumftances, the common farmer in America had a more comprehenfive view of his rights and privileges, than the fpeculative philolopher of Europe, ever could have of the fubject. The one was in a fituation, where the language, dictates, and defigns of nature, were perpctually occurring to his views: The other was in a Gtuation, where every thing in fociety had deviated from nature; and with infinite labour and ftudy, the firft principles, muft be deduced from theory and reafoning. Learning their principles from the ftate of fociety in America, Paine, and other writers upon American politics, met with amazing fuccels: Not becaule they taught the people principles, which they did not before underitand; but becaufe they placed the principles which they had learned of them, in a very clear and frik- 
ing light, on a molt critical and important occafion.

When the war came on, the leaders of mobs, and the mobs which they created, appeared in their true light : The former funk into contempt, and the latter were foon fuppreffed. The enlightened, virtuous, fubftantial body of uncorrupted citizens, took up the bufinels. Unacquainted with the ftate of fociety liere, Europe faw with wonder, the fpirit of freedom unconquerable in America: Rifing, the more it fuffered, the more fuperiour to all the attempts of the wifeft and moft powerful nation of Europe. The minifters of Britain at that time, were men of great eminence and abilities, in managing bufinefs, upon the European fyfem : But they had no ideas of the ftate of things in America, or of a fyftem in which nature and fociety had combined to produce and to preferve freedom. What they called rebellion, was only the tendency of nature and fociety towards freedom, made more active, by their oppofition. Miftaking the caufe, they perpetually miftook in their meafures: And what could not have happened from any other caule but total miftake, it was their fingular ill fortune never to judge right, either through defign, or by miftake. - The refult was the natural effect of things. It did not partake of the nature of miracles, of the extravagant pirit of chivalry, or of the madnefs of religious or political enthufrafm. It was nothing more than the natural effect, of natural caules. Freedom, for a contury and an half, had been the conftant product and effect, of the ftate of fociety in the Britith colonies: And when the decifive trial was to be made, this fate of fociety produced its natural effect ; a firm, neady, unabating, and unceafing conteft, which could not admit of any other period, but the total deftruction, or complete eftablifhment of freedom. 
No other caufe but that which firft produced the frecdom of America, will prove fufficient to fupport and preferve it. It is in the Rate of fociety that civil freedom has its origin, and fupport. The effect can never be more pure or perfect, than the caufes from whence it arifes; and all thofe caules terminate in the ftate and condition of the people. The form of government by which the public bufi$n e{ }^{2}$ is to be done, a bill of rights to alcertain the juft claims of the people, a conftitution to direct and reftrain the legiflature, a code of laws to guide and direct the sxecutive authority, are matters of high importance to any pcople; and are juftly eftecmed among the wileft productions, of ancient or modern cimes. But no people ought to expect that any thing of this nature will avail to fecure, or to perpetuate their liberties. Such things are confequences, not the caufes; the evidences, not the origin of the liberties of the people. They derive their whole authority and force, from the public fentiment; and are of no further avail to fecure the liberties of the people, than as they tend to exprefs, to form, and to preferve the public opinion. If this alters and changes, any bill of rights, any conftitution or form of government, and law, may eafily be fet afide, be changed, or be made of none effect. For it will never be dangerous for the government of any peo. ple, to make any altcrations or changes, which the public opinion will either allow, juftify, or fupport. Nor ought any people to expect, that their legifacors or governors will be able to preferve their liberties, for a long period of time. Any body of men who enjay the powers and profits of public employinents, will unavoidably wifh to have thofe profits and powers increafed. The difficulties they will meet with in the execution of their office, the unreafonable oppofition that will be made by many to their wifent and belt meafures, and the conftant at- 
tempts to difplace them, by thofe whofe only aim and with is to fucceed them; fuch things, joined with a natural love of power and profit, will not fail to convince all men in public employments, that it would be beft for the public to put more confidence and power in them. While they thus wifh and aim to increafe and add ftrength to their own powers and cmoluments, thofe powers and emoluments will be called the powers and the dignity of government. It may be doubted whether men, are much to blame, for wifhing and aiming at that, which their filuation and employment naturally leads to. The effect feems to be univerfal. It has ever been the cale that government has had an univerfal tendency, to increale its own powers, revenues, and influence, No people ought to expect that things will have a different tendency amorig them: That men will ceafe to be men, or become a more pure and perfect order of beings, becaufe they have the powers of government committed to them.

Upon what then can the people depend, for the fupport and prefervation of their rights and freedom? Upon no beings or precautions under heaven, but themfelves. The fpirit of liberty is a living principle. It lives in the minds, principles, and fentiments of the people. It lives in their induftry, virtue, and public fentiment: Or rather it is produced, preferved, and kept alive, by the ftate of fociety. If the body of the people fhall lofe their property. their knowledge, and their virtue, their greateft and moft valuable blefings are loft at the fame time. With the lofs of thefe, public fentiment will be corrupted: With the corruption of the public fentiment, bills of rights, conftitutions written upon paper and all the volumes of written law, will !ofe their force, and utility. Their government will immediately begin to change: And when the people have themfelves loft the caufe, the principle, and the fpir- 
376 THE NATURAL AND CIVIL, E⿱宀.

it of freedom, they will no longer be capable of a free government: They are better fuited for the reftraints of ariftocracy, or what is far better, for the regulations of monarchy. The conflitutions and the laws of fuch a people, will no more preferve their freedom, than the tombs and the coffins of Montefquieu and Franklin, will retain their abilities and virtues.

Y'e people of the United States of America, behold here the precarious foundation upon which ye hold your liberties. They reft not upon things written upon paper, nor upon the virtues, the vices, or the defigns of other men, but they depend upon yourfelves; upon your maintaining your property, your knowledge, and your virtue. Nature and fociety have joined to produce, and to eftablifh freedom in America. You are now in the full polfeffion of all your natural and civil rights; under no reftraints in acquiring knowledge, property, or the highefk honours of your country; in the moft rapid ftate of improvement, and population; with perfect freedom to make further improvements in your own condition. In this fate of fociety, every thing is adapted to promote the profperity, the importance, and the improvement of the body of the people.-But nothing is fo eftablifhed among men, but that it may change and vary. If you thould lofe that fpirit of induftry, of economy, of knowledge, and of virtue, which led you to independence and to empire, then, but not until then, will you lofe your freedom : Preferve your 'virtues, and your freedom will be perpetual! 


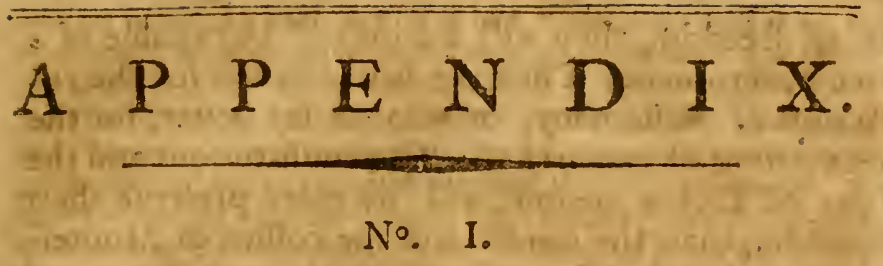

An Account of the Variation of :be magnetic Needle, in the eafiern States. Chap. I. p. 18 .

$\mathrm{N}$ laying out lands in America, the direction of the lines, is generally taken by the magnetic needle. The inftruments which have been generally ufed, are the Plain Table, or the Citcumferentor, divided into degrees, and fitted with a magnetic needle of three or four inches radius.-Had the greateft poifible care been taken by able mathematicians, it would not have beer poffible for them, with fuch inftruments, to have avoided many errors and miftakes. But in fcarcely any inftance has the variation of the needle been known, or at all attended to. Many, and almolt endlefs controverfies and lawfuits, have arifen. from this caufe. In many inftances no data could be found, by which it was polfble to come to a juft decifion; the variation of the unagnetic needle, at the times when the conteffed lines were run, being unknown. On fuch accounts, the knowledge of the magnetic variations in the inland parts of America, is become a matter of great importance to the people; their intereft and proper. sy in many cafec, being much affected by it.

From the year 1302, the diretive power of the magnet has been employed with great fuscefs, in the affairs of ravigation. Bat the firtt account that we have of any obferved variation in its direction, was by Columbus, in the year 14,92, in his firft voyage to America. Until that time, phiiofophers uniformly believed that the pole of the magnet, exuctly coincided with the pole of the earth; and they had no idea of any fuch thing, as a variation. Amidt the uncommon fcenes of difficulty which oppofed the views, and exercifed the genius of the difcoverer of America, when he had advanced two hundred leagues weft of the Canary Inands, his compafs began to fail him; and it was found not to point to the pole of the earth, or exadly north, but one degree to the weft of that point. From that time the variation began to be obferved, and became more and more known. For the lati cen:ury and an half, mathematician; have made it a regular part of their bufinefs to obferve it, in different parts of the earth; with the amisal alcerations that are contantly raking place.

In the year 1723, a very accurate obferver, G. Graham, of Lon* don, difcovered that the magnetic nesd!c hôd a diurnal, as we!! 
as an annual variation. And it is now well known to philofo. phers that from about eight o'clock in the morning, the mag . retis needle verges to the weft, until about two o'clock in the afternoon. When it has attained its greateft weftward variatior, it gradually returns to the eaft, until about eight or nine o'clock in the evening; when it becomes ftationary, until the next morning - Tables expreffive of this diurnal variation are become common; and are to be found in the tranfactions of all philofophical focieties. Thus in the moft regular ftate of the magnecic needle, it is conftantly fubject to two variations; an annual, and a diurnal one.

The effect of thefe variations are at all times fuch, that the magnetic needle can never give to the furvevor who follows irs directions, a ftraight or an accurate line. And it ought not be ufed at all, where the bufinets requires great accurasy and precilion. It is however fearcely practicable in America, to lubftituse any thing betrer, in the room of it: Molt of the lines which have been already run by furveyors, were rum by the needle; this is much the.moft convenient inftrument that can be carried, or uled in the woods ; the expenle of running lines any orher ivay, would be too great for individuals to bear; and the furveyors, are not qualified to run them by the true meridian. For fuch reafons it is probable that the nuagnecic needle will fill consinue to be the infrument, by which the lines will be run, and the townthips helaid out in America.-We mut therefore endeavon to provide the bell remedy we can, for an errorctevil. which we cannot eafily rtinne. The beft remedy which the sasle adraiss of, is an accurate obfervation of the variation of the magnetic needle, at the time when divifional lines are run. This ihould be done by able mathematicians, and in as inany places in a. late, as may be. Such objervations will afford the belt direction, furveyors will be able to find, to enable them to detcrmine what is the real or true direction of their magneric lines - It is wich this view, that the following Table is fubjoined. 


\section{$\begin{array}{llllllll}A & P & P & E & N & D & I & X .\end{array}$}

Magnesic Obfervations made in Canzada, and the eaffern States of Anerica.

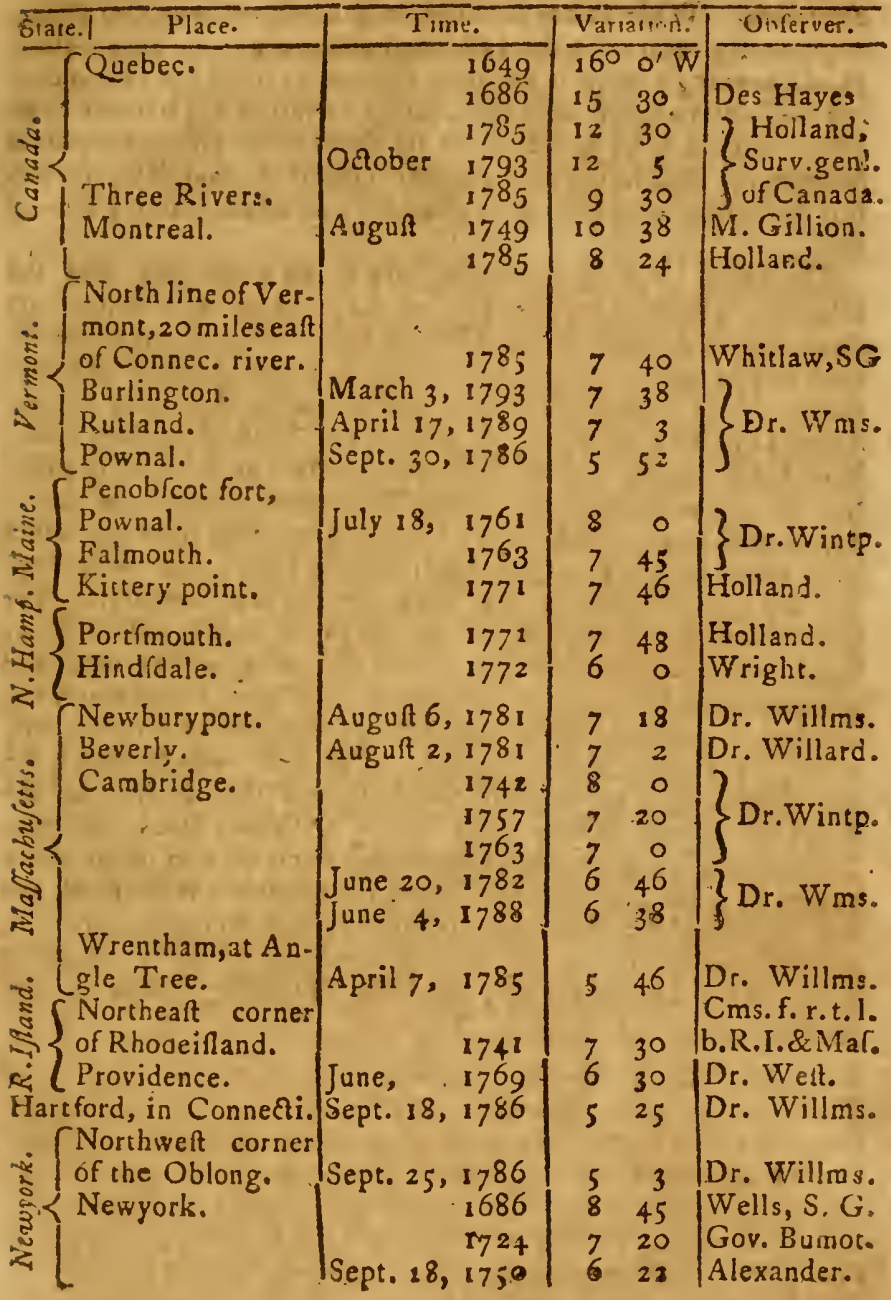


Obfervations on the Clange of Climate in Europes and orlier Flaces. Cे А. IV. P. 65 .

$7 H E$ change of climate which has taken place in Northamer1 ica, has teen a matter of conftant obfervation and experience. It feems to be the aniverfal opinion of hiftorians and philorephers, that there has been a more remarkable change of climate throughout ail Europe. There are fevetal pheriomena from which it may be thown with much certainty, that this has been the cafe in feveral places.

In the land of Palefine, about the latitude of 30 or 3 i degrees, north. the autho: of the rook'of Job makes ufe of fuch language as thie, "Fiaft thou entered into the trealures of the frow? Or hat thou feen the treafures of the hail ?-Out of whofe womb - ane the ice :-And the hoary froft of heaven, who hath gen. dered it :-The watirs are bid ar wilh a fone, and tke face of tle dept is frozen." Job xxxviii. 22.29, 30. "Thele are probably the words of Mofes. And they are exprefive of that degree of colc, in which the furface of water is fo frongly frozen as to con. ceal its fuidity, and refemble the confiftence and hardnefs of ilone. The degree of heat in which this effect takes place in rivers, ponos, and lasge collections of water, I have generally found to be about 2 ; degrees of 'Farenheit's thermometer ; wilh a duration of a week or ten days. We fhall not therefore be far from the trueh, if we conclude that the extremity of the cold in the land of Midion, could not have been lers than 25 degrees, in the days of Mofes: And that fuch a cold, was of fome days duration. Sucl was the degree, and the effect of the cold in the land of the Midianites, about $32 \frac{4}{3}$ centuries ago.

In the writings of David we have alfo a defcription, of what was efteemed a levere feafon. "He giveth fnow like wool: He fcattereth the hoar frolt like anes. He caftelb forlh bis ice like marels : Who can fiand before his cold :" Pfalm cxlvii. i6, 17. 'This account muft have been written at leaft $28 \frac{1}{2}$ centuries ago. The language of the poet cioes very frongly exprefs the effee?, which the cold had on the feelings of men in tbat warm climate. But the account which he gives of the appearance and form of the ice, denotes a lefs degree of cold than what took place in the days of Moles. When the degree of heat is but 31 degrees of Farenheit's thermometer, the ice may appear to be caft into the form of morlels and crytals: And this feems to have been the greateft degree of confiftence, extent, and hardnefs, in which the poet had either feen it, or conceived of it.-It hould feem theretore that from the time of Moies to David, the cold had abated in the lant of Palefine: That four centuries before, it hid the waters as with a ftone, and caufed the face of the deep to be 


\section{A $P$ P E N D I. X. 38 :}

frozen : But that now it only caft ont the ice like morfels or cryfsals. The difference in the degree of cold neceffary to produce shele effeets, is about 6 degrees.

We have here an account of the climate in the land of $P$ alefsine, fo far.back as 28 and 32 centuries. Inftead of treasures of fnow, hail, and ice, a frozen deep, and cold which car. fcarce be flood before, the inhabitants of that country now find a hot, fultry climate; in which fnow and ice are never feen. We have rot an account of any meteorological obferrations made at the places, whicre Mofes and David lived. The climate is probably much the fame at thofe places, as it is in others of a fimilar latitude and fituation. We may therefore make ufe of thofe which have been made at Grand ( airo, as the moft applicable, and the beft which we can find, to give us an idea of the tcmperature of the winter in thole parts of the globe. Grand Cairo lies in the latituce of $30^{\circ}$ ncrth. According to Mr. Nicbur's obfervations made there in the years $: 761$ and 1762 , the mean heat of thole years was $73^{\circ}, 65$. The mean heat in the month of Jauvary was $37^{\circ}$; that of February was $63^{\circ}{ }^{*}$ * $I_{t}$ is but feldom that the mean heat of the fevereft werk in the winter, falls more than 7 or 8 degrecs below the mean temperature of the whole month. This will give 49 degrees, as the mean temperature of the fevereft week, in the winter at Grand Cairo. And this cannot be greatly different from the temperature of the winter, in the land of Paleftine. Frois this way of computation, we thall have 24 degrees of Farenheit's thermometer, as 'the alteration which has taken place in the feverity of the winters in that country, fince the time of Mofes.

The climate in Iraly is aifo found to be very different now, from what it was 18 centuries ago. Virgil, the celebrated pcet, was diftinguithed alfo by his knowledge in agriculture. In his georgics he is frequently giving advice for the fecurity of cattle, againft the dangerous effeets of ice and fnow. His directions were defigned for the country round Mantua or Naples, his native place, in the latitude of $41^{\circ}$. Mentioning Calabria the prof fouthern part of Italy, he fpeaks of the freezing of the rivers, as an event that was commonly to be expeded. Pliny, Juvenal, and Elian, writers in the firt and fecond centuries, fpeak of ice and fnow as what was common in Italy. One of thefe writers, Elian, has a chapter which confifts aliogether of inftructions how to fith for eels, when the water is covered with ice.-The degree of cold neceffary to effect this, cannot be eftimated at a lefs degree than 25. From the meteorologicalobfervations which were made at Rome in the years 1782 and 1783 , it appears that the mean heat in the month of January at that place, is now 46 de$f_{2}$ rees; and that the mean heat of the coldeft week in the winter

$$
\text { * Voyage, Vol. I. }
$$


was 42 degrees; $* 17$ degrees greater than that, in which the permanent freezing of rivers takes place. The change of climate therefare in ltaly during the laft 18 centuries, cannot bave been lels than 17 degrees; but from the inaccuracy of the ancient accounts it may have been many more.

A fimilar change has taken place in the country round Confantinople, and the Euxine or Black Ssa. This we collect from the works of Ovid. This celebrated poet was banithed to 'Jomos, by the Roman emperor. This place is in the latitude of $44^{\circ}$; and lies near the coaft of the Euxine fea. The poet fpent feven years in his banifhment at this place, about the sniddle of the firft century. He informs us that he faw the Euxine fea covered with ice: That he walked upon this ice ; and that oxen and carriages paffed over it. Ho goes farther, and adds, that when he called for wine in a fevere feafon, it was prefented to him in a ftate of congelation: And that the fnow in many places, was never diflolved during the fummer feafon. Tournefort obferves that in the days of Conftantine, the ftreight of Byzantium was frozen over: And that in the year 401 , the Euxine fea was covered with ice for 20 days together. - We have not any meteorological obfervations to ftate with exaetrels, what the prelent temperature of that climate is. But nothing would be more uncommon and extraordinary, than to fee this fea frozen over now. In 1667 , the Turks were greatly aftonifhed at the appearance of fome ice at Conftantirople: And in all the adjacent country, inftead of a frozen rea, frozen wine, and perpetual fnow, they have now a fine moderate warm climate; one of the moft luxuriant, and de. lightful, that is to be found upon the face of the earth. So far as we can judge from the general phenomena, the change of the climate there, has been fully equal to what has taken place in Italy.

The fame alteration has been oblerved upon the Alps and Appenines. Thefe are the higheft mountains in Europe, and divide Italy from France, Switzerland, and Germany. The march of Hannibal's army over thele mountains, was one of the moft memorable exploits of antiquity. In their accounts of it, Livy and Polybius in almolt every line, are mentioning the extreme difficulty and fufferings which arofe from the fevere frofts, ice, and fnow. Thefe mountains are eafily pafted now. Armies have frequently crofled them without any un. common fufferings, from the time of Francis the firft.t

The change of climate has been allo very remarkable in Germany. Two circumftances have marked this with certainty. By the account of Diodorus Siculus: 1. "The great riv. ers

- Ephem. Soc. Metor. Palat. Obfervationes Romanz, Tom. II \&: III. + Plil. Trans. Vol, LVIII, for 176.9 , p. 58, \&as. 


\section{$\begin{array}{llllllllllll}A & P & P & E & N & D & I & -X . & 383\end{array}$}

ers which covered the Roman provinces, the Rhine and the $D$ anube, were frequently frozen over, and capable of fupport:ing the molt enormous weights. 'The barbarians who ofter. chofe that fevere feafon for their inroads, tranfported without: apprehenfion or danger, their numerous armies, their cavalry, and their heavy waggons over a vait and folid bridge of ice. Modern ages have not prelented an inftance of a like phenomenon. 2. The reindeer, that ufeful animal, from whom the favage of the north derives the beft comfort of his dreary life, is of a conftitution that fupports and even requires the moft intenle cold. He is found on the rock of Spitzberg, within ten degrees of the pole; he feems to delight in the fnows of kapland and siberia. But at prefent he cannot fubfift, much. lefs multiply in any country to the fouth of the Baltic. In the time of Cefar, the reindeer, as well as the elk, and the wild bull, was a native of the Hercynian foreft, which then uverhadowed a great part of Germany and Polazd."*

Thefe accounts will affilt us to form fome general idea of the climate of Germany at that time. The freezing of the Rhine and the Danube is mentioned, as an event that was annually to be expeeted; what the barbariaris always found to take place in the fevere feafon; and to fuch a degree, as to afford them a certain and a fafe paffage for the heavieft burdens, and for the largeft armies. This account of the ftrength, fimnefs, and duration of the ice, conveys the idea of a winier equal in all its effects, to that which takes place in the uncultivated parts of Northamerica. The rivers are here conftantly frozen every winter. The inhabitants find by conftant experience, that at that feafon of the year they can tranfport their heavieft effects, and the greateft weights, with fafety, certainty, and convenience.-The mean heat of our, winters in fuch places, is from 15 to 20 degrees. In fuch a cold, the rivers and ftreams will be fo conftantly and fteadily frozen, that the inhabitants find a certain and a fafe paffage every winter, over the rivers and lakes. This feems to have been very much the ftate of the ancient German winter. From the oblervations which were made at Vienna, latitude $48^{\circ}-12^{\prime}$ north, in the years 1779 and 1780 , it appears that the mean lieat there in the month of January was $27^{\circ}, 5$; in February it was $33^{\circ}, 23$. At Ratilbon, latitude $4^{\circ}{ }^{\circ}-5^{\prime}$ north, in the years 1781 and 1782 , the mean heat in the month of January was found to be $30^{\circ}, 5^{2}$; that of February was $30^{\circ}, 76$. A: Manheim, latitude $49^{\circ}-27^{\prime}$ north, in the years 1.781 and 1782 , the mean heat in the month of January was $35^{\circ}, 08$; in Feb. suary it was $35^{\circ}, 8 .+$ The mean of thefe, $31^{\circ}, 3$ in January.s.

* Gibbon's Roman Hiftory, Vol. I, p. 346. and.

+ Fphetl, Soc, Mltteos. Yalat, 'Tom, I, II, III, \&ze. 
and $33^{\circ}, 26$ in February, wi!l accurately exprefs the prefent remperature of the German winter upon the Danube and the Rhine.- The time when the barbatians began their inroads into the Roman provinces was about the ycar 222. Accord -. ing to this computation, the change of climate in Germany has been between 11 and 16 degrees, in $15 \frac{x}{2}$ centuries.

The other inftance mentioned by the hiftorian, and which ferves to mark the climate in Germany in the time of Cæfar, was the appearance of the reindeer. The warmelt countries in which he now refides, are Sweden, Ruflia, and Lapland. From the abfervations made at $A$ bo, latitude $60^{\circ}-27^{\prime}$ not th, from the year 1750 to, 1.761 the mean heat in the month of January, was tound to be $19^{\circ}: 5^{8}$; that of Eebruary was $21^{\circ}, 38$. At Peterlburg, latitude $59^{\circ}-55^{\prime}$ north, from the ycar 1762 to 1777 , the mean heat in January, was $10^{\circ}$; in February, the mean heat was $16^{\circ}, 4_{2} 6$. The mean of thefe $14^{\circ}, 8$ in January, and $18^{\circ}, 9$ in Februaty is the temperature of the winter in that part of the globe.* Thefe are the warmelt climates in which the reindeer does now fubfilt. It may therefore with much probability be inferred, that this was the temperature of the German winter in the daj's of Cielar, $18 \%$ centuries ago. Hence the alteration of climate in Germany during that fpace of time, has been about ${ }_{1} 6$ degrees. It feems to be a confirmation of the truth and propriety of thefe, differeat methods of computa!ion, that they bath afford much the fame refult.

From thefe accouats it appears with a decifive evidence, that the climate, in the courfe of feveral centuries, has re: markably changed at Paleftine, in Italy, around the Euxine fea, at the Alps, and throughout, all Germany. Tnrough all this vaft extent of country, the climate is now become 16 or 17 degrees warmer than it was 18 centuries ago: I Ihe continent of America in finilar latitudes, is ftill fubject to a great degree of cold. If the meteorological obfervations which have been made at Williamlburg, Camoridge, Quebec, and Iiudlon's Bay in Anerica, be compared with thole which have been made at Algiers, Rome, Poifliers, and Solyfkamiki, places whofe tatitudes ate nearly equal ; t it will be found that the European continent is now $1:$ degrees warmer than that of America. Many inquiries and fpeculations have been propored to account for this extreme cold of America. IFom the accounts which have heen mentioned, it appears that 17 or 28 centuries ago, the continen of Europe in!tead of being

* Kirvazils effimat:.

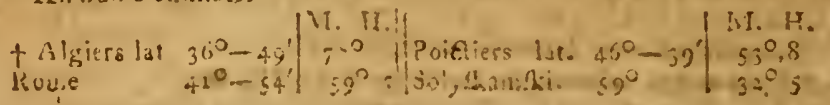




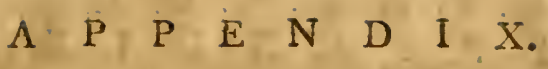

I: degrees warmer, was fubject to a cold 4 or 5 degrees greater, than that which now takes place on the continent of $A$. inerica. The proper inquiries therefore feem to be, Wherice. is it that the European continent is become fo much more mild and temperate than that of America?-Whether the latter will not in a courfe of time become equally warm and temperate as the former? - Whether the climates of both will not gradually become more equal, uniform, and moderate, than they now are?-And, Whether cultivation is fufficient to account for thefe changes ? For whatever the caufe may be, the fact feems to be certain, the heat of all that part of the earth, of which we have any ancient accounts, has been increafing from the earlieft ages.

\section{No. III.}

A Didertation on the Colours of Men, particularly on that of the tit. dians of America. CHA P. VIII. p. 197.

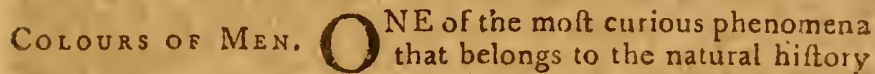
of man, is the colour with which he is marked. Every object. which we behold, appears to be of fom particular colour. In animals thefe colours are extremely various, different, and Leautiful; and fometimes they appear to be variable. Man, like other animals, is diftinguined both by a peculiarity, and by a variety of colour. In Europe, he appears white : In Africa, he is black: In America, his colour is red: In Ala, a variety of colours are to be found upon the human countenance. There are other thades and tinctures to be found in each quarter of the globe, befides thofe mentioned above: But thofe that have been mentioned are the molt general and prevalent colours, under which man appears, in the four general divifions of the globe.

VARIETY OF COLOURS. - The moft diftinguifhing, permanent, and general colours of the human fpecies, and which are at the greateft extremes from each other, are black and white. Between thefe, or rather as different degrees and variations of them, are all the other colours of the human countenance : And they rnay be reduced to fwarthy, red, copper, and brown.-Black is the colour of the Africans under the equaror; of the inhabitanis of Newguinea, and Newholland. A fivariby colour includes the Moors in the northern parts of Africa, and the Hottentots in the fouthern parts of it. Red diftinguifhes the Indians of Northamerica. The fame, or perhaps inore accurately a copfer colrur denotes the complexion

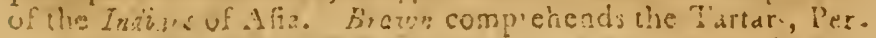

$$
\text { A a } 3 \text { fides, }
$$


fians, Arabs, Africans on the coaft of the Mediterranean, and. the Chinefe. The inhabitants of the inands in the Pacifio Ocean, are alfo chrefly of this colour. Under this colour is comprehended all thofe different thades, which ase denoted, by olive, chefnut, and deep yellow. A lefs dark colour, or broxnilh, will beft exprefs the complexion of the inhabitants in the fouthern parts of Europe: The Sicillians, Abj Ifinians, Spaniards, Turks; and allo the Samoiedes, and Lap'anders. Ithite is the colour of rnoft of the European nations; as Swedes, Ruftians. Danes, Englih, Germans, Poles, \&c. Kabardinfki, and Georgians. It is oblervable that all thefe colours are included between the two extremes; or tather they are different degiees or variations of black and white.

CHANGE OE COLOUR. A change of colour is a! ways pro. duced by the mairiage or m'xture of pe uns of difierent complexions. Thu the offspring of the European and the negro, is of a yellow complexion; le!s white than the European, and. Jefs black than the negro; or rather of a dark creain colour. Th:s sace are sumerous in fome parts of America, and are called Muintioes. The offspring of an European and an Indian. is allo of a cream colour; and more light than the malaltoe. Thefe are callod among the Spaniards Meftigor. The effect and operalion of this change of the original colcur, in the climate of America, is aluays in favour of the fairer compiexion; and never approaches iowasds, or ends iri the darker coour. - Thus change and aiteration of colour, whẹn it is lett tw) its natural tendency and effect, is extremely fow and modcrate in its operation; and it is not until afier many yeans, that the full eflect is produced, In the Spanilh fettlements, this mixed race la. fo multiplied as in form a confiderable part of the inhabilants: And the leveral itages of variation in this race, with the gradual alteratien of thade until it ends in the European complexion, have been well afcertained, and are now perfectly we!l underftood. Thole of the firlt generation are confidered, and treated as negroes or Indians. In the third generation the Indian colour difappears. It is no: antil the fifth defcent that the deeper black of the negro is loft. At the end of thefe different periods, the offispring can no longer be diftinguifhed from the European ; but is confiderad as fuch, and entitled to all their privileges.*-In this. change of colour, produced by the moft powerful of all natural caules, the mixture of perfons of different complexions; fo gradual and flow is the operation, that the black mult be fubject to five divifions, and the operation muft be continued through five generations, before the colour is completely changed.

- Voyage de Ulloa, I. 27. Robertion's Hift. Amer. II. 352. 


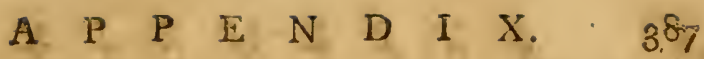

SEAT OF COzOUR.-That the different colours of the hu. man fpecies are feated in the fkin is very apparent. The fkin zonfifts of three folds or coverings. The firft is a very fine and tranfparent integument, and is white in people of all colours. The fecond is a cellular membrane, differently coloured in different perfons. The third is alfo white. It is in the lecond of thefe, that the colour is feated. In black people, a very able anatomift* oblerves that the fkin is much thicker and larger, than in white ones; the cellularmembrane in the latter beiog a thin mucus, but in the former a thick membrane. In whites this feat of the colour is ttanfparent, and either totally deprived of veffels, or only furnifhed witi a very few; as the yellow colour appearing in jaundice van. ithes on the caufe of the difeafe being removed, which is not the cafe with Atains from gunpowder, or fimilar caules. Hence, ho obferves, three caufes may be very readily afigned, which will operate to deftroy the pelucidity of the $\mathrm{fkin}$, and give it a brown colour, and render it thicker. Thele are the heat of the lun, the accels of air, and naftinefs. And in general any thing that operates to produce or to deltioy the pelucidity of the Rin, will tend to vary and change the colour of the human body.

Coleur CONAECted Witu Cirmate.-Among the caufes which may affect the colour of the human body, it has been generally fuppofed that the influence of heat or climate, has a confiderabie effett. Concerning this infuence or connexion between colour and climate, the following oblervations may be made.

1. Different colours are bef fuited to different climates. In all the plants and animals which are fpread over the face of the earth, there is fomething by which they are peculiarly fitted to the climate and country, in which they are placed. One kind of vegetable requires a great degree of heat: $\mathrm{An}$ other flourifhes the beft in a temperate and cold country. It is the fame with animals. Some are fitted for the heat of the torrid zQne. Others require the fevere cold of the frigid zone, to give tisem their greateft perfection. Toall thefe animals, nature has given the proper clothing: which admits of no other variation than what the feafons of the year require.-Man is an animal made for every climate? Inttead of being formed for the torrid or frigid zune, he can live, multiply, and arrive to his proper perfection, in any climate: And it is left to his own reafon and indultry to provide himfelf with fuch clothing, as his condition may require, in every climate through which he may pars; or in which he may fojourı. And yet there is lomething in different men, whicls

- Dostor Hunter. çualifies 
qualifies and fits them for one climate, better than for ancthe"; and that is, colour. - The man whole colour is black, is better fuited to the extreme heat of the lotteft climate, than any other of the human race. This has been long known and obferved in the climates of America. The negroes of the Weflindia inands, in the Spanim dominions, and in the fates of Georgia, and South. carolina, are found to bear the extreme heat of the fummer be:ter than the white people. On the contrary, the negroes in the northern flates of America are more tender than the white pesple, lefs able to bear the feverity of our winters, and more apt to complain, fuffer, and freeze with the cold. - The white men are the reverfe of this. They besr the fevere winters of Canada, and Ruffia, without mich dificulty or fuffering : But in an hot climate they become frckly, and fail fooner than the negroes. Several colonies of white peop!e have fubfifted in the torrid zone in America, more than tivo centuries: And yet they cannot bear the heat, like the original inhabitants, or like the negroes. The one is apparently beft fuited to a cold, and the other 'to a hot climate. And thefe differences are as apparently owing to their colour, for they do not appear to be connected with any other caufe, or circumftance. Different colours therefore in the human fpecies, are certainly beft acapted, fitted and fuited, to differen climates.

2. There is a tendency in climate to produce the colour which it requires. Animal heat is cerived but little from the fun, or from lie atmofphere; but chiefly and mainly from original cor. Atitution. The defign of covering and clothing, is to detain and preferve the heat of the animal body, in its natural fituation, degree, and quanity; and to prevent an extreme wafte or di?. nerfion of it. Black readily receives and abforbs the heat of the animal body; and in this way, tends to exhnut and difperic it. White reflects and repels the rays of light and heat more than any ctlier colour, and thus prevents and oppofes their paffage; and in this way, tends to preferve and detain the connttuitional heat of the animal body. Hence the covering, whish nature lias afigned to the earth in cold climates, is fnow : $B y$ its colour it tecomes beft of all adapted to prevent the heat from flowing out of the earth into the atmofophere. And hence the covering of moft animals in the fevereft feafon, and country, is gererally white; the color: which moft of all preferves the heat of the animal body, and prevents its flowing out. In conformity to the fame law of nature, many animals change their col. our at the approach of winter; and from black, brown, or grey, become wlite. This is the cafe with the rabbits, foxes, and bears, sc. at Hudfon's bay, Rufia, and Siberia. From the darker colours which they bear in fummer, they turn white at he approach of winter; and remain fo, until the return of fpring. 


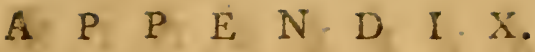

In fuch cafss, climate appears to have a powerfol and a fudden operation, to produce the colouis it requires.

The change of colour in man, is more fiou and gradual: It is however certain and apparent. The white men who are much expofed to the heat and rays of the fun, and to the influence of the wind, in hot feafons lofe their whitenefs, and become bown or red. 'The inhabitants of Europe when they fettle in Nerufpair or in the Weftindia illands, foon lofe their whitenefs, and tsecome of a brownith yellow. The Europeans who refide long in the Eaftindies, becomc of the lame cream coloused complexion. We have an accurate account of the effect produced by climate in Southamerica, by Dr. Mitchel!: "The Spaniards who have inhabited America under the torrid zane for any conficerable time, are become as dark coloured as our native Indians of Wirginia, of which 1 myfeif have been a witnefs."* An account from Africa, is equally authentic and accurate, "There are feveral other fmall Portuguefe fet:lements, and one of fome note at Mitomba, a river in Sienua Leon. The people here called Portuguefe, are principally perfons bred from a mixture of the firt Portuguefe difcoverers with the natives, and now become, in their complesion, and woolly guality of their hair, perfect taegroes, rewsining however, a fmattering of the Portuguele language." + Here the operation of mixture by marriage, is determined by climate in favour of the African colour. There are fimilar accounts of the complexion of the Portuguefe, who fettled at Senegal in 1400; and of thofe who are fettled on the coall of Congo. The varying complexion of the Jews is alfo very remarkable. Defcended from one flock, their religion has prevented their marrying with other pcople. In Britain and Germany, they are white. In France and Turkey, they are brown. In Spain and Portugal, their colour is fisarthy. In Syria and Chaldea, the olive colour prevails: In Arabia and Egypt they are of a taway or copper colour.t Among cyery nation they feem to partake of the colour of the climate. And one of them, Tudela, relates that his countrymen in Abyfinia, have acquired the dark complexion of the origiral natives.

It is obfervable that all thefe changes, are from a light, to a more dark complexion. Similar changes have not been obferv. ed in the negroes, that have been brought into the temperate climates of America. It mould feem therefore that the tranfition is eafier from white to black, than from black to white; or that the negro colour is the roof deeply impreffed of any; or that heat has a much more fudden and powerful effect than cold. It ought however to be obferved that it is only in white and fair

* Phil. Trañis. No. 476 . complexions,

+ Account of the trade of Greatbritain to Africa, by an African mer. chant.

t Buffon Nat, Hitt. Vol, III. 


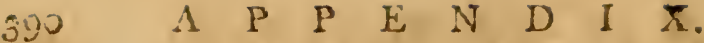

complcxions, that thefe changes of colour would foon becorac rifible, or apparent to common obfervation. In a dark or black countenance, fmall and gradual variations of thade would not be obferved. It would not be until the negro had lost much of his former colour, that the change would be generally noticed.-But I much fufpect that these is fomething more curious in this fubjest, than has been imagined: That lome of the colours of the hmman countenance, are in their own nature, colours which are lefs changeable than others. It feems to be univerfally the cafe, that the black produced bo fcorching, or by an interfe heat, is the molt durable of any colour whatever: And that white is more foon and eafily fullied, and changed, than any of the other co'ours, with which any object is marked.

3. It feems to be a confirmation of thefe remarks, that the colburs of men in difterent climates, are in fact fuch, as thafe cli. mates feem to require. Under the equator the darkeft thade, perfed black takes place. The negro of Africa is placed in the moft intenfe heat, that takes place on this globe; and the colour of the negro is the deepeft and darkeft black, that any where appears on the human countenance. Advancing from the equator soly ards the pole, the colour of the human fpecies acquires a com. plexion nure and more light ; until having paffed through all the insormediate gradations of hade, it terminates in the whitencts of a temperate and cold climate. - There are indecd variations and exceptions from this, and irom every other generai law of nature. Intermixtures of difierent nations, migration, differences in ford, difeafe, cleanliness, health, and many other local circumflances and caufes, will produce thefe. As fuch variations are no: agreeable to any general law of nature, they are neither cvidences c., or ot,jections to fuch laws; but derive their origin from local and particular caufes. - But it is impoffible not to dif. cern the general regularity, tendency, and effect of the laws of mature, refpecting climate and colour. The moft intenfe black, is the gencral colour of man in the hotteft part of the globe. Where the heat is confidcrably abated, the black abates too, and she cotour becomes fwarthy. To this fuccecds the red or copper colour of the eaft and wef Indians: fuited to that part of Afa, where the Indians have been long fixed and permanently fettled. The next gradation is brown, comprehending the olive, and dark yellow. A lighter Made, or a brown approaching nearer to "hite, diftinguilheth a climate ftill more teaperate. The who!e trminates in the coldnefs, and in the whitenefs of the European and northern nations; beyond which nature has not proceeded. And where a country is of great extent, as India, and China, the colour of the Came people is dark in the fouthern, and more fisir in the northern parts. Whatever particular exceptions and daviatious may be found, the general law of nature refpeeting colours 


\section{$\begin{array}{llllllllll}A & \mathrm{P} & \mathrm{P} & \mathrm{E} & \mathrm{N} & \mathrm{D} & \mathrm{I} & \mathrm{X} . & 3 & 3\end{array}$}

Eolour, is marked with as much regularity, uniformity, defign, and order, as any other law of nature, which applies to the vegesable or animal world.

4. This operation and effect of climate muß be extremely grad. ual and now. Wharever thofe caufes are which have ferved to form and fix the colours of men, they are caufes which have beer in operation, from the beginning of the creation of God. If store were any differences in the natural conftitutions of men, fo as to form what has been called different races, thofe differences mutt have been original; and therefore as ancient as thofe fuppofed races of men. If the effect has been produced by climase, this caufe mut have been operating upon nations, ever fince their sefictence became fixed in any particular part of the earth. The fame remark will apply to any other luppofed caufe. Be it what is may, upon every nation whofe refidence has been fixed, it must: have been operating ever fince their fituation became eftablifhed. With regard then to all thofe nations which have long refided in the fame part of the globe, their colours muft be viewed as the effect of caufes, which have been in operation either from the beginning of the creation, or from the time when they began to refide in their prefent fituations, or countries.-What then ought in be expected, if any race of men whofe cclour was already formed, thould be removed 10 a country, where the tendency of climate was to reverfe the former effects, and change the colour which hat been long fixed ?-Could it be expected that the pow. er of climate to change a colour long formed and fixed, could be exerted in lefs time than it had required to produce and to enab. lifh it ? - Would is require lels time to remove an eltablifhed colour, and to produce a new one, than it did to produce and fix the firft? So far as we can derive any information from the ordinary cuurfe of nature, we cannot conceive that the colour of the negro, could be chanced into that of the white man, in a lefs period of time, than it had taken, 10 produce and eftabliah that colour at firft. $t$ is much more probable, that a longer period of time would be neceffary to eradicate the firf, and produce the fecond, than was requifite to form the complexion at firft.- Thofe then that mean to inquire carefully into the operations and effects of nature, mut put on the patience of the antiquarian, and learn to compute time with the aftronomers. The impatience of many leads them to expect that climate fhould undo that in three or four generations, which nature has been conftantly at work to effect, from her firft origin until now.

I will venture to propole a conjedural eftimation, not becauf: I think it approaches very near to certainly or decifion, but be. caufe I canuot find any thing upon the fuhject, that has a greatex appearance of probability. The moft powerful of all the caufes, which have been found to change the complexion of man, is that of mixture by marriage. In the negro colow, this requires five 
gencratigns, and five divifons, Ecfore the African blackness is lof in the European whitenefs: to the lefs dark complexion of the Iucian, it requires three generations, and three divifuns, to produce the fame effect. iT he time of one of thefe generations may bie eltimated at about twenty five years. The time then which Dature requires to effect the change of colcur from this caufe, would be one bundred and twenty five years, for the negro. A thirty lec. ond part of the whole colour, 'upon this fuppofition is cone away by forne other caufe, fay that of climate. If the whole effect had been produced by climate, and in this proportion, the time nec. cfrary to have completed the effect would have been four thou. fand years. By the fame method of conjeaural eltimation, the sime ncceffary to reduce the Indian to the European colour, would be fix hurdred years. - The difficulty and uncertainty attending this method of forming an eftimate, is not that ic can give the period of time too long, but that it affumes what can. not bc afcersained by obfervation. It is not, and probably cannot be inade certain by obfervation, that a thirty fecond part of the negro colour is done away by climate, or that it is done away at all, when the negro complexion is fuppoled to be curopletely changed. It is not probable that if a tinirty fecond part of the dark colour remained, it could be readily difinguithed by the eye.- But uncertain as the data are, they are fuficient to maw that the operation of climate, in any view in which the natter can be confidered, is extremely gradual and tlow. Eut

5. This influence of climate, whatever it is, may' be increa?ed, or it may be retarded, by the operation of other caules. The colour of the kin may be affected and changed by other caufes, as well as by heat and coid. If there be any thing in the common method of living, in being conftantly expoled to the fun and wind, in the ufe of paint and oil, or in an habitwal cleanlinefs or filthinefs, that iends to darken, or to render the complexion more fair; this, may oxerate either with or ayainft the influence of climate, according as the nature and tendency of fuch cuftom or praftice may be. And we ought not to afcribc that to, or make that any objection to the influence of climate, which may be derved from oiher caufes. Thus in Grecriland, the influence of climatc is in favour of a Fair and white complexion. But in the confant application of grede, oil, and filthinefs, to the hunan body, there is anrither and a moie ponerful caufe to effect its colour, than clinate; and which, acting in conltant oppofition to it, give; lo the countenance a fallow or dity ulve complexion. Sh. h caufes may a $e^{2}$ with a forcc and power, equal or luperiour to that of climate; but they a:e not equa ly permanent, univerfal, or intaridulc. - Theis is ro eiror more comalon. or more apt to deceive us in contemplating the natural hiltory of man, than to afcribe that :o one caule, which is de!tved from or [loduced 


\section{$\begin{array}{llllllll}\text { A } & P & \mathrm{P} & \mathrm{E} & \mathrm{N} & \mathrm{D} & 1 & \mathrm{X}\end{array}$}

produced by the joint operation of many. Whatever tends to render the fkin more or lefs tranfparent, will affect the colour of the human Ipecies, as certainly as the climate in which they are placed.'

Colourand Citmate orthe Indans of America.There is no fubject in philofophy fo well underftood, but that a tumber of queftions and inquiries may be propofed refpecting it, which do not admit of a fatisfactory or complete an. fwer. And this will always remain to be the cafe, becaufe our knowledge of nature will never be equal or commenfurate to the fubject. Buit there is one inquiry arifing here, which demands our careful attention: How does the climate and the colour of the Indians of America agree with this, or with any other fuppoled law of climate? The Indians were fpread over the whole continent of America: They dwelt in every habitable climate from the equator to the pole: And they were of the fame colour in every place. In the greateft heat under the equator, and in the fevereft climates of Canada and Hud: fon's bay, they were of the fame brownifh red.* This appears to be the proper Indian colour in every part and climate of America. Are the climates of America different from thofe of the other cortinent ? Or whence is it that the connexion which takes place between climates and colour in the other parts of the globe; is not to bo found among the Indians ? This curious plienomenon has occafioned much inquiry and fpeculation: Can the caufes of it be found, in the oblervations which have been already mentioned?

1. The Indian colour is very evidently the mixture of black and red. The colour, which an intenfe heat produces, upon all bodies to which it is applied, is black : And it is as natural $\mathrm{Bb}$ b to

* It has been cuftomary to vrite in this language, but vine are far from being certain that it is either accurate, or proper: It has been taken for granted, bue it has never been examined, whether the Indian colour is the fame in every part of America. An accurate and inquifitive obferver, M: de le Pinto, who conmanded for feveral years at Matagrofla, a Poltuguefe fettlement in the interiour parts of Brafil, where tlie Indians are numerous, and not alsered by their intercourfe with the Europeans, noted a diterence in their complexions: "They are all of a copper col: sur, with fome diverfity of Made, not in proportion to their diftance from the equator, but according to the degree of elevation of the territory which they intrabit. Thofe who lize in a high country are fairer than ihofe in the narifhy low lands on the coafi." - Robeitfon's Hift. Ante. 1. $460 .-\mathrm{O}$, the morthweft part of the American continent, it has been

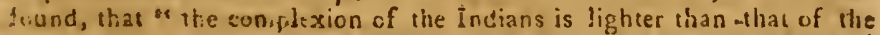
Eutuhern Indians, and fome of their women have rofy cheeks." - Molfe's Grog. 1. 99. 105 . Edit. 1793.-Cf the Ir dians of Yuraguay we have this acculln: "They are geverally of an olive complexion, fomed.uks:, ahers lizhtsr, and f.ms ac whita as the Spaniards," - Ibid, B, 8 s. 
to expeet it thould have this effet upon the human body, as upon any other bodies. The colour which is produced upon the human body, by living much in the open air, expoled to the influence of the fun and wind, is red. The white merr who live in fuch a fituation, always contract this colour. That part of their bodies, which is expofed to the influence of the fun and wind, becomes of a reddin colour; or as it is co:. monly expresed, they become tanned, or fun burnt; that is, they acquire a colour formed by a mixture of red and white.m This influence of the wind and fun, in producing the red complexion, is found to be much the fame in fummer and winter: 'The white man is nearly as much, and as foon tanned, in the winter as in the fummer. It feems therefore that the produntion of this red colour, does not depend upon climate, heat, or cold, but upon babit; the habit of living in the open air, and having the body expofed to the conflant infuence of the fun and wind.--The In. dian colour then feems to have been formed by the mixture of two different colours, black and red; and to have been derived from two powenful caufes, climate and babit: Caufes difinct from one another, and the latter producing nearly the fame effect in every climate.

2. This colous of the Indians was probably completely formed, when they firlt came into America. They were of the fane colour as the Indians, and fouthern Tartars ir. Afia ; and ap. pear to have been defcerided from them. Their colour therefore ivas completely formed and fixed, before they came into America. This colour feems to have been derircd from the warm climate of $A$ fita ; and from the habit of living conftantly expofed to the fun, and to the ofen air. The colour thus formed and fixed, they would naturally convey to their offspring. And as there were no other people with whom they could have any intercourfe, there could be no change or alieration of colour, produced by a mixture of parents of difierent complessions.. Their colour therefore mutt have been fettled, and uniform : And the whole effeet of population muft have been to fpread, propagate, and preferve it. The effect of climate then upon the Irdian in America, would not be to produce and form his colour; but ei$\therefore$ it to pieferve, or to change it.

3. No part of the climace of America was fufficiently hot, to changec it into an inrenfe black. It is only in the moft intenfe heat of the hutsefl climate, that the extreme black of the negro is tormed. The climate of America under the line falls far fhert of this. "While the Regro on the coaft o! Africa is farched with unremittng heat, the inhabitant of Perubreathes an aireaually mild and ternperate, and is perpetually fhaded under a cano. py of grey clouds, which intercept the ficrce beams of the fun."

"Roberton's Hift. Ameri. I. 253 . 


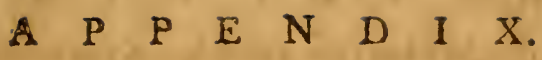

The climate in every part of the torrid zone in America, is much more mild and temperate than the fame latitude in Africa, or Afia. In a country where the hotteft climate is fo moderate, it is not to be expeeted that the Indian colour frould be changed into extreme black. No part of the climate was lot enough to produce this : And any fmall variation in the $\mathrm{In}$ dian countenance, would not be readily or eafily difcerned.

4. The change of colour molt naturally to be expeeled would be of the contrary kind, not to black, but to white; at leaft to a lighter thade than what took place under the equator. If there be any influence or tendency in extreme cold to produce a fair and white complexion, this might have been exfe; ted; for there are no colder climates upon the face of the earth, than thofe of the northern parts of America.-But whatever might be the infuence of the climate to produce fuch a complexion, the Indians made ufo of feveral certain and contant methods to frevent it. One, was their conftant habit of living and wandering about in the woods, expofed to the full force of the winds and fun : Another, was their excreme and perpetual filth, and dirtinefs : A third, was their habitual ufe of greafe and paint. It was their univerfal cuftom to anoint and rub their bodies a ith the greafe and oil of the bear, beaver, mufkrat, and other animals; and to mix the greafe with different kinds of painte, and gums. This practice was probably defigned to protect the body againft the extreme variations of heat, cold, and moifture, to which tisey were conftantly expofed. Nor could they have provided any better defence againf heat, cold, rain, and infeets, than thus to cover their bodies with a glutinous kind of varnin. And in doing this, they took a fure and a certain method, to fix and preferve their colour from any approaches to a white, or to a fais complexion. When extreme dirtinels was added to the greafe, oil, and paint, neither climate or aey other caufe could produce 2 fair complexion, until thefe were removed and difufed. Thus in the Indian cuftoms, and method of guarding his body againit she effects of climate, the Indian himfelf was taking conitant care that nothing thould change the colour of his Ikin, or make it more tranfparent. But

5. Where thefe cuftoms have been difufed, the Indian colour has been found to be changeable. It has never been decided whether the Indian colour is exactly the fame in every pait of America. No accurate comparifons have ever been made besween the colour of the Indians in the hotteft parts under the e. quator, and thofe in the remote regions of Canada and Hudion's bay. Their colours have never been compared to any accurate and known ftandard; and fmall variations in a dark complexion, would rot be a matter of common obfervation. - But whether the Indian colour be the fame in every part of America, or not, $i$ is certainly more shangeable, and not fo deeply fixed, as that of 
the regro. Many families of the Indian tribes are to be found in feveral of our towns. Some of thefe are at Capecod, and Rhodeifland: A confiderable number of them, are at Natic, and Stockbridge, in Maffachufetts. Their habits and manners of life are different from thofe of the Indians, who retide in the forefts. They live in houfes, have a fixed place of refidence, and have much difufed the cultom of paints and oils; and their complexion differs much from that of the tribes who yet remair. in their ancieni and original tate. The reddifh caft is abated. The tawny afpect appears more dull, pale, and clouded. The crimfon mixture has difappeared, and they have approximated. much nearer to the colour of the hunter among the whites, than? the tribes who retain their ancient cuftoms and habits. This. change of colour in the Indians who have lived long among the whites, is apparent to common obfervation. And it is apparent. Iy derived from the change in their manners, cufoms, and habits. This change of the Indian complexion, clearly thows what has been the effect of cuftom, and habit.

6. In the northern parts of $A$ merica, there are permanent phe. nomena, which will ferve allo to how what has been the cffec? of climate. The Efquimaux in the northern parts of America, are a people remarkably different from the Indians, which occupy the other parts of the continent. There is not much room to doubt, but that they were derived from the northwęt parts of Europe ; are the fame people with the Greenlanders, Lap. landers, Zemblans, and Samojeds; and like them, were defcended from the Tartars in the eall. Their defcent then was prob. ably from the fame nation as the Indians: But while the Indian tribes have by cuftom, preferved their red complexion, the Ef: quimaux have acquired a fallow olive, or brownith colour; more inclining to the European whitenefs, than to the brownifh red. of the American...-To what caufe can we abfcribe the lighter co'our of this branch of the Tartar race, but to their more north. erly and frozen fituation: They have adopted the fame cuftoms and habits, as the Indians. They rub and anoint their bodie:, with greafe, the fat of the feal, and train oil; and are as filthy as the Indians. Nat only fo, but they drink the fat of the feal, and their train oil, and efteem it the moft pleafant liquor. Can' it be doubted what mult be the effect upon their colour? It op. erates againt the infuence of climate, in that part of the easth where climate operates moft powerfully to produce a white com:plexion. The influence of the two caures is divided, but the ballance is in favour of climate, and the European complexion. Thus in two very extenfive and numerous kinss of men, deriv. ed from the fame nation, climate, cuftom, and habit, in one part of America, have produced or preferved the dark crimfon of the Indian; but in the moft northerly and frozen parts of the continent, the fame caufes have eftablimed the fallow olive colour 


\section{A. P P E N D I X. 397}

of the Equimaux, more referabling the European whitenefs, than the Indian red. Upon a sareful attentios then, to the colours and cuftoms of the original inhabitints of America, the fhenomena feem to confirm the general connexion which nas taker place between climate and colour, in the various parss of the othis hemifphere.

This part of the natural hifory of man, feems to be but very imperfectly undertiood. The great difficulty that attends it, is the want of ancient and accurate accounts. It does indeed feem to be pretty well decermined, that the colour of the white man is eafily, and foon changed, to a dark complexion; And that the colour of the Indian is changeable, into a lighter complexion. But no relations which I have teen afford the lame information, refpeting the change of the African black. Nor can I find any phenomena or accounts which ferve to afcertain the matter, and put it out of all doubt, whether there has been any change in the colour of the negroes, which have been brought into any part of America. Nor is it certain that any fuch apparent alteration of the negrocolour, ought upon any hypothefis to have been ex. peated, in the courie of four or tive generations. And yet, until forse of thefe fact Thall be afcertained, we can hardly expect tbat the laws of nature which apply to this fubject, will be un. derltood.-Impatient of the fatigue of inguiry, collecting and comparing phenomena, fome philofophers, with great precipita. tion, have pretended 10 decide it by fyftem. To folve all difficulties it has been declared by fome, that there are different creations, and races of men : That the white man is one kind, the regro another, and the Indian a third, \&c.-The bufinefs of making fyflems for nature, has feldom anfwered any other pur. pofe, than to dilcover the prefumption of thofe, who have made them. It has proved fo in this cafe. If there had been as many local creations as there are individuals, this would not afford ue any information, or enable us to advance one ftep, towards \& folution of the problem refpecting the colours of different men. Still the inquiries would remain, What is the feat of colour in thefe different men? Why da the rays of light appear of fuch different colours, upon the Ikins of the one, and the other? Why dees one colour appear moft common in an hor, and another colour prevail the mott in a cold climate? And how is the change of colour produced by marriage and mixture ?-Inftead of amufing ourfelves with theories that are attended witn no evidence, and can be of no ufe, what is wanted in this fubjeet, is careful and accurate obfervations. Thefe will indeed require a long courfe of time, and abilities very different from thofe, which decide by metaphifical difputes and ffeculations. But it is the only method, in which we have any reafon to exped our knowledge of this fubject will be promoted? 


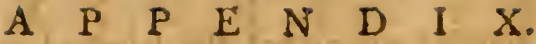

$$
\text { No. IV. }
$$

The Declaration and Petition of the Inbabitants of the Newbamp. Bire Grants to Congre/s, announing itbe $D_{i j}=i E l$ to be a Free and Independent Siale. Cна P. IX. P. 233.

To the Honourable the ConrinenTAI Congress.

THE declaration and petition of that part of Northameri. 1 ca, fituate fouth of Canada line, welt of Connecticut river, north of tho Maffachusetts bay, and eaft of a twenty mile line from Hudfon's river, containing about one hundred and forty four townfhips, of the conients of lix miles fquare, each granted your petitioners by the authority of Newhamp. fhire, befides feveral grants made by the authority of Newyork, and a quantity of vacant land, humbly theweth,

That your petitioners, by virtue of feveral grants made shem by the authority aforefaid, have many years fince, with their families, become actual fettlers and inhabitants of the faid defcribed premifes; by which it is now become a refpectable frontier to three neighbouring tates, and is of great im. portance to our common barrier Ticonderoga ; as it has furnifhed the army there with much provifions, and can multer more than five thoufand hardy foldiers, capable of bearing arms in defence of American liberty:

That thortly after your petitioners began their fettlements, a party of land jobbers in the city and ftate of Newyork, began to claim the lands, and took mealures to have them declared to be within that jurifdiction :

- That on the fourth day of July, $17 \sigma_{4}$, the king of Greatbritain did nals an order in council, extending the jurifdiction of Newyork government to Connedticut river, in confequence of a reprefentation made by the late Lieutenantgov: ernor Colden, that for the convenience of trade, and admin. iftration of juftice, the inhabitants were defirous of being an. nexed to that ftate :

'That on this alteration of jurifdiction, the faid Lieutenantgovernor Colden did grant feveral tratts of land in the above defcribed limits, to certain perfons living in the llate of Newyork, which were at that time in the attual poffelfion of your. petitioners; and under colour of the lawful authority of faid itate, did proceed againft your petitioners, as lawlefs intrud. ers upon the crown lands in their province. This produced an application to the king of Greatbritain from your petitioners, fetting forth their claims under the government of Newhampthire, and the difurbance and interruption they. liad fuffered from faid poft claimanto, under Newyork. And en the $24^{\text {th }}$ day of July, 1767 , an order was palfed at Sto jawes's, protribiting the governors of Newyork, for the time 


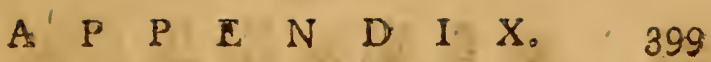

being, from granting any part of the defcribed premifes, on pain of incurring his higheit difpleafure. Neverthelefs tho lame Lieutenantgovernor Colden, Governors Dunmore and Tryon, have eacn and every of them, in their refpective turns of adminiftration, prefumed to violate the faid royal order, by making feveral grants of the prohibited premifes, and countenancing an actual invation of your. petitioners, by force of arms, to drive them of from their poffeftions.

Thofe violent proceedings, (with the folemn declaration of the fupreme court of Newyork, that the charters, conveyances dic. of your petitioners' lands, were utterly null and void) on which they were founded, reduced your petitioners to the difagrceable necefitity of laking up arms, as the only means left for the fecurity of their poffeffions. The confequence of this itep was the palling twelve aets of outlawry, by the legiflature of Newyork, on the ninth day of March, 1774 ; which were not intended for the Atate in general, but only for part of the counties of Albany and Charlotte, viz. fuch parts there. of as are covered by the Newhampthire charters.

Your petitioners having had no reprefentative in that affembly, when thele atts were paffed, they firft came to the knowledge of them by public papers, in which they were in. ferted. By thefe, they were informed, that if three or more of them affembled together to oppofe what faid affembly called legal authority, that fuch as thould be found affembled to the number of three or more, thould be adjudged feions: And that in cale they or any of them, hould not furrender him. felf or themfelves to certain officers appointed for the purpofe of fecuring them after a warning of feventy days, that then it thould be lawful for the refpeetive judges of the fupreme court of the province of Newyork, to award execution of Dealh, the fame as though he or they had been attainted before a proper court of judicatory. Thefe laws were evidently calculated to intimidate your petitioners into a tame furrender of their rights, and fuch a tate of vaffalage, as would entail mifery on their lateft polterity.

It appears to your petitioners, then an infringement on theis rights is ftill meditated by the ftate of Newyork; as we find that in their general convention at Harlem, the fecond day of Auguft laft, it was unanimoufly voted, "That all quitrents formerly due and owing to the crown of Greatbritain within this ftate, are now due and owing to this convention, or fuch future government as may hereafter be eftablifhed in this ftate."

By a fubmiffion to the claims of Newyork, your petitioners would be fubjected to the payment of two Rillings and fix pence fterling on every hundred acres annually; which, com. pared with the quitrents of Leving fton's, Phillips's, and Ran.

dear's 
Ilear's manors, and many other enormous trats in the beft fituations in the ftate, would lay the moft difproportionate Share of the public expenfe on your petitioners, in all refpects the leaft able to bear it.

The convention of Newyo: $\mathrm{k}$ have now nearly completed a code of laws, for the future government of that ftate; which, Thould they be attempted to be pue in execution, will fubjeet your petitioners to the fatal neceffity of oppofing them by cvery means in their power.

When the declaration of the honourable the Continental Congrefs of the fourth of July laft paft, reached your petitioners, they communicated it throughout the whole of their dif. trict; and being properly apprized of the propoled meeting; delegates from the feveral counties and towns in the diftrict, defcribed in the preamble to this petition, did meet at Weftminfter in faid diftrick, and after feveral adjournments for the purpofe of forming themfelves into a diftinct and feparate ftate; did make and publith a Declaration, "that they would at all times thereafter confider themfelves as a free and independent ftate, capable of regulating their own internal police, in all and every refpect what foever; and that the people in the faid defcribed diftrikt, have the fole exclufive right of governing themfelves in fuch a manner and form, as they in their wifdom thould choofe: not repugnant to any refolves of the honourable the Continental Congrefs:" And for the mutual fup. port of each other in the maintenance of the freedom and in = dependence of faid diftriet or feparate ftace, the faid delegates did jointly and feverally pledge themfelves to each other, by ail the ties that are held facred among men, and refolve and declare, that they were at all times ready, in conjunction with their brethren of the United States, to contribute their full proportion towards maintaining the prefent juft war againft the fleets and armies of Greatbritain.

To convey this declaration and refolution to your honourable body, the gtand reprefentative of the United States, were we (your more immediate petitioners) delegated by the united and unanimous voices of the reprefentatives of the whole body of the fettlers on the defcribed premifes, in whofe namo and behalf, We humbly pray, that the faid declaration may be received, and the diftrict defcribed therein be ranked by your honours, among the free and independent American fiates, and delegates therefrom admitted to feats in the grand Continental Congrefs, and your petitioners as in duty bound Shall ever pray.

Newbanflifirc Grants, Weflminfter, 15th, Jan. 1777.

Signed by order, and in *half of laid inhabitants.
JONAS FAY.

THOMAS CHITTENDEN. HIEMAN $P_{2}$ L,LEN. REUBEN JONES. NC. 


\section{A P E N D I X.}

\section{No. V.}

The Remonftrance of the Commishoners from Vermont againft the Procesdings of Congrels, Sepiember 22, 1780. CHAP. X. P. 2.56 .

To the Honourable CONGRESS of the UNITED STATES of. NORTHAMERICA.

TTHE remonftrance of Ira Allen and Stephen R. Bradley, 1 commiffioners from the free and independent ftate of Vermont, appointed for the time being to attend on Congreis.

With plealurc they embrace this firft opportunity to teftify their thanks for the petfonal. honour done them by Congrels, in giving them an attendance though in a private capacity, with their honoucable body: At the fame time lament the neceffity which obliges them to fay, they can no longer fit as idle fpectators, without betraying the truft repoled in them, and doing violence to their feelings, to fee partial modes purfued, plans. adopted, ex parte evidence exhibited, which derives all its authority from the atteitation of the party; paffages of writings felected giving very falfe reprefentations of facts, to anfwer no other end but to prejudice your honourable body againft the State of Vermont; thereby to intrigue and baffle a brave and meritorious people out of their rights and liberties. We can eafily conceive the fecretary's office of the ftate of Newyork, my be converted into an inexhauftible fource to furnifh evidence to anfwer their purpofe in the prefent difpute.

Needlers would it be for us to inform Congrefs, that by the mode of trial now adopted, the ftate of Vermont can have no hearing without denying itfelf: And to clofe with thole refolutions, which we conceive our enemies have extorted from your honourable body, and on which the trial is now placed, would be in fact, taking upon ourfelves that humility and felf abafement, as to lofe our political life, in order to find it.

We believe the wifdom of Congrefs fufficient to point out, that purfuing the prefent mode, is deviating from every principle of the laws of nature, or nations: For if the difpute is between the ftates claiming on the one part, and the ftate of Vernont on the other, whether the latter be a ftate de jure, as an independent jurifdiction de facio; they oughi to be confidered in the courfe of the difpute, until the powers interpofing, have determined whether the latter be an independent juridiction de jirt, if not they of courfe ought to annitilate the jurifdic. tion de fasto; but to annihilate the ftate de fact, in the firft place, -is fummarily ending the difpute; to deny the latter any independent jurifailt:on $d \in f_{w} . t 2$, is to deny there is any longer garlies in the difpute.

C c c

Agzin 
Again we conceive the means connected with the end, and upon no principle whatever can we jultify, that either part fhould eltablin the modus, or rules to be purfued in deter mining dilputes, without confounding every idea of right and wrong. - In the prelent cafe, on the one part might the end as juitiy have been eftablithed as the way and means to effect. the end.

We are far from being willing thofe brave and ftrenuous efforis made by the ftate of Vermont in the controverfy with Greatbritain, thould bo buried by our grafping adverfaries, (thistting after domination and prey') in the ipecious pretext of riotounly affuraing government ; and we thereby lofe all credit fer the men and money we have expended.

Thus while we are neceflitated to remonttrate again th the proceedings of Congrefs on the prefent mode, we are willing at the fame time any equitable ingairy thould be made, the ftate of Vermont bering allowed equal privileges with the other fates in the difpute.

And that the fate of Vermont might Rand fortifec to your hinourabie body, and to the world, boin as to her preient and future conduet, we are intuccd, as well from principles of a:t.uchesent to the Aulerican caufe, as a regard we have for peace and harmory among the ftates of Amcrica now at war with Greatbriain, to make the lo!lowing propolala, viz:

1, t That the ftate of Vermonit will as foon as may be for. ward to the fecretary of Congrefs, an altefted selurn of all male perlons, liable to do duiy agreeabic to a milisia af here. tofore cxhibited to Conglels in a code of laws, entilled os the Laws of Ve:mont;" and the ftate of Vermont thall for and during the prefent war with Greatbritain, from year to year furnith an equal number of troops in the ficld in propgrion to their numbers, as Congiefs fhall eftimate the quotas of the 1cveral United States in proportion to their numbers; which troops thall be clothed, quartered, and paid, by the tta:e of Vermort. And at the clofe of the war, the difpute Mall be rquitably fettled by the mediation of fovereign powers; and nothing herein contained, fhall be conflued to lake away the right any of the United States claim to have in or over the flate of Vermont : Or

adly. We are willing to agree upon fome ons or more of the legifatures of the difintercfted ftates to interpole as mediators, and lettle the difpute: Or

$3 \%$. We are willing Congrefs, being puffe:Ted of fovereign. ' $y$, hould interpole to prevent the effufion of human blocd: At the fame time, we seprobate every idea of Congrefs fittirig as a court of judicature, to determine the difpute by virtue of authority given them by the aet or acts of the ftatcor ftates that make but one party. 


\section{A. P P E N D I K.}

It gives us pungent grief that fuch an important caufe at: this juncture of affairs, on which our all depends, Thould be forced on by any gentlemen profering themfelves friends to the caufe of America, with fuch vehemence and lpirit as appears on the part of the ftate of Newyork : And Shall oniy add, that if the matter be thus purfued, we ftand ready to appeal to God and the world, who muft be accountable for the awful confequences that may enfue.

Signed at Ybiladilpbia this 20 d day of September, A. D. 1780 . IRA ALLEN.

STEPHEN R.BRADLEY.

\section{No. VI.}

Ou fions propoled by tise Comwittee of Congrefs to the Agen/s on the Part of Vermont, wit's the Anfwers of the Agents, Auguft 18,1781 .

ouffion 1/. A RE the boundaries fet forth in the written Quefion 1 $/$. A propofitions delivered in by the faid Agents at this time, claimed by the flate of Vermont as the lines of jurifd dtion, the fame as contained in the refolution of Congrefs of the ; th of Auguft inftant?

Anjwer. They are the fame, with the addition of part of the waters of Lake Champlain, for the benefit of trade.

2. 2\%. What part do the people of Vermont mean to take as to the paft expentes of the prefent war, and what aid do they propofe to afford as to men and money to the common defence?

$A$. Such proportion as thall be mutually judged equitab!c after their admiffion to a feat in Congrefs; which has been at feveral different times officially propoled by agents un the part of Vermont.

2. $3^{d}$. What are the ideas of the people of Vermont rela. tive to the claim of private property, under grants or patents from Newhamplnire, or Newyork previous to the prefent revolution?

A. Alhough the fate of Vermont have not hithcrto au. thorized any courcs to take cognizance of fuch caufes as refpect titles of lands, neverthelefs they have had, and ftill have it in contemplation to adopt fuch modes as the circumitances arifing out of each cafe may juftify, without adhering to the ftritet rules of law.

2. $4^{t h}$. What are the intentions of your conitituents in regard to the patents that were granted on conditions of feitlement within a given time, and which have been prevented by the claims of the people of Vermont, and the prefent revo. Iution? 


\section{A}

A. No forfeitures have been taken by the ftate of Vermont on any fuch grants for nonperformance of conditions of fettlement, and we conceive it to be the intention of our conftituents to grant a further realonable time for fulfiling luch conditions.

2. $5^{t b}$. What are the number of inhabitants within the lines mentioned in the propofitions above mentioned?

A. As the citizens of Vermont have not been lately num. bered, we can the refore only eftimate them at thirty thoufand, which we conceive to be nearly a true eftimate.

2. $6 t b$. What quantity of land is contained within the faid bounds?

A. There has been no accurate furvey of the ftate of $\mathrm{Ver}$ mont, but we conceive it to contain about five millions of acres.

2. 7 th. What applications have been made either publicly or privately by the enemies of the United States, or their adherents, to draw off the people of Vermont fiom their affecrion to the United States of America ?

A. The honourable committee are poffeffed of copies of Bev. Robinfon's letters inclofed in Brigadiergeneral Allen's letter of the 9 th day of March laft, to the then Prefident of Congrefs, and any private offers we cannot avouch for.

2. $8 \%$. In cale the enemy thould attempt an invafion of the northern fronticrs, what aid as to men and provifions could be raifed in the ftate of Vermont for the public defence (you can fuppole the invafion made in different quarters) and in what time?

$A$. The number of militia within the lines herein limited, we fuppofe to be about feven thoufand; are in general well armed and accoutred, and have ever fhown themfelves Ppirited in care of alarms, \&c. In regard to provifions, the country is fertile, but.new, and confiderable emigrations from other ftates to Vermont. - The legiflature at their feffion in October laft, levied a tax on the inhabitants fufficient for victualling one thoufand five hundred troops in the field for twelve months, and we are of opinion a larger ftore may be in the fame manner collelted the enfuing autumn.

\section{No. VII.}

An Account of the rateable Proferts, and of the Number of Inbabitants in Vermont, at different Periods of Time.

\section{B.EN I I G TON COUNTY.}

Names of the Tuwns. Value of the ratablt Value of the rata N Numb. of property in the yeal ble property in the lnhab. in
r 781 year 1791.

Bennington

shaftibury

$$
\mid \begin{array}{r}
1.11898 \\
9118
\end{array}
$$




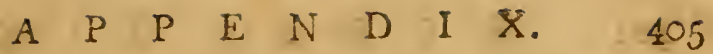

Nanes of the Towns /Valu: of the rataul. Value of the ratable|Numb; of

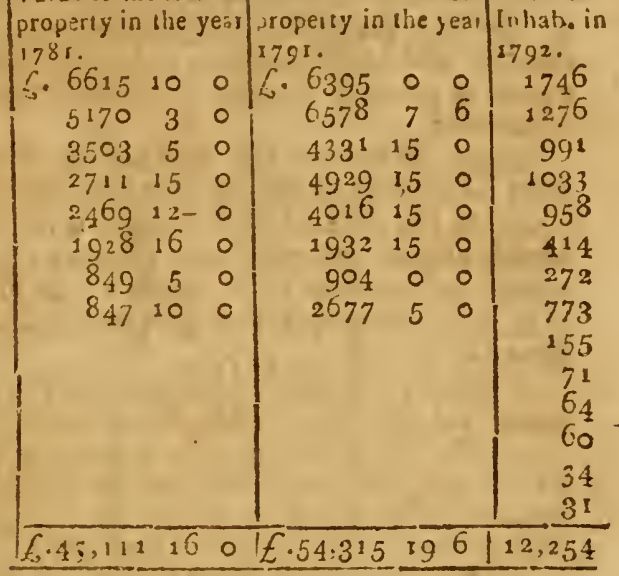

Pownal

Manchefter

Arlington

Rupert

1) jifet

Sunderland

S: ainford

Sandgate

Windhall

Bromly

Reen fbraugh

Woodiard

Giaftonbury,

Landgrove

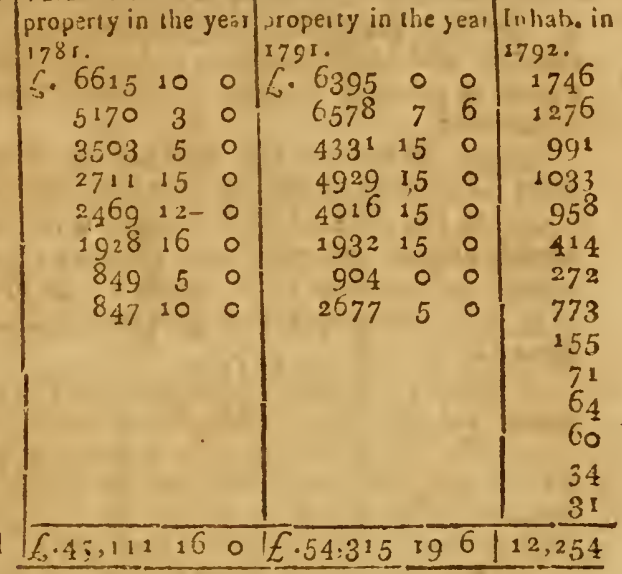

WINDHAM COUNTY.

Guildford

Bratileborough

Weftminfter

Putney

Halifax

Rockingham

Dummerlton

Marlborough

Wilmington

Hinfdale

Newfane

Townfend

Londonderry

Whitingham

Athens

Thomlinfon

Jamaica

Wardiboro' N. D.

Wardboro' S. D.

Somerfett

Stratton

Johnfon's Gore

\begin{tabular}{rrr|rrr|r}
$583^{6}$ & 10 & 0 & 6717 & 11 & 0 & 2432 \\
4999 & 10 & 0 & 5969 & 12 & 6 & 1589 \\
4982 & 5 & 0 & 6695 & 10 & 0 & 1601 \\
4835 & 8 & 0 & $613^{8}$ & 10 & 0 & 1848 \\
3569 & 16 & 0 & 4640 & 10 & 0 & 1309 \\
3363 & 0 & 0 & 4832 & 15 & 0 & 1235 \\
2970 & 0 & 0 & 4978 & 0 & 0 & 1501 \\
1881 & 10 & 0 & 2676 & 0 & 0 & 629 \\
1874 & 0 & 0 & 2735 & 10 & 0 & 645 \\
1869 & 0 & 0 & 1908 & 0 & 0 & 482 \\
1687 & 6 & 0 & 2597 & 0 & 0 & 660 \\
1462 & 5 & 0 & 2463 & 16 & 0 & 676 \\
886 & 10 & 0 & 1560 & 10 & 0 & 362 \\
693 & 10 & 0 & 1352 & 5 & 0 & 442 \\
442 & 17 & 0 & 1212 & 5 & 0 & 450 \\
200 & 0 & 0 & 1422 & 15 & 0 & 561 \\
186 & 10 & 0 & 663 & 15 & 0 & 263 \\
& & $175^{8}$ & 10 & 0 & 483 \\
& & 1009 & 15 & 0 & 270 \\
& & & & & 111 \\
41,738 & 17 & 0 & $6.61,332$ & 9 & 6 & 17,693 \\
\hline
\end{tabular}

WINDSOR COUNTY.

Windfor

Norwiçh

Totall

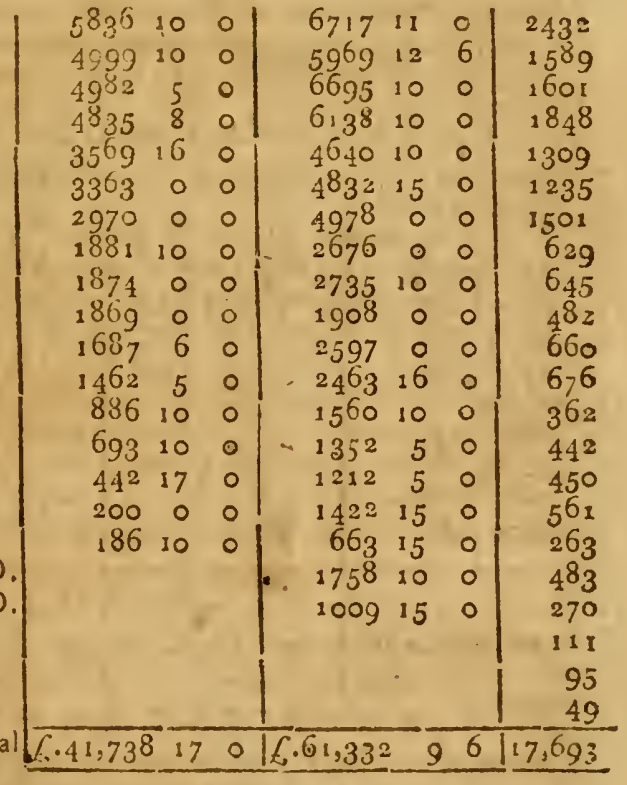

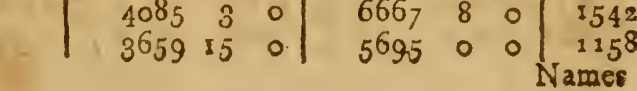




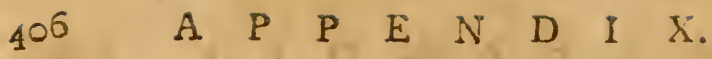

Names of the Towns. Value of the rata. Value of the rata-fNumb. of

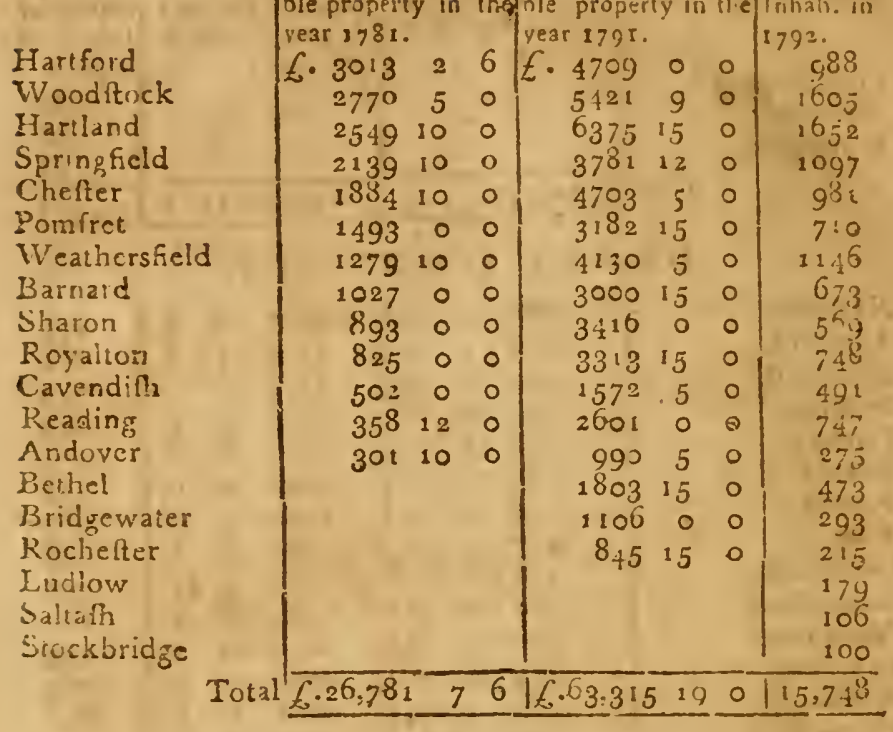

RUTLAND COUNTY.

Rutland

Clatendon

Tinmouth

Danby

Pawlet

Zoultney

Wells

Caftleton

Walling ford

Yittsford

Ira

Shrewfoury

Jiarwick

Middletown

Orwell

Brandon

Eairhaven

Benfon

Yluobardton

Sudbury

Chittenden

Pittsfeld

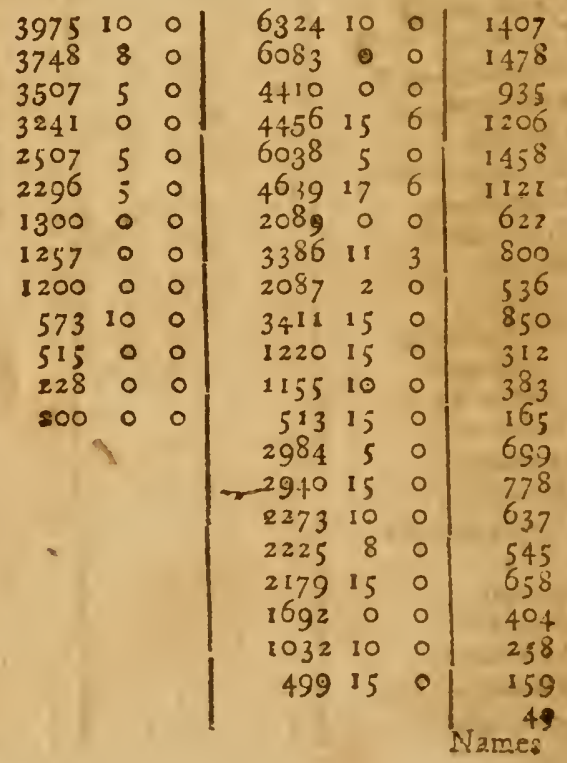




\section{A $P \quad P \quad E \quad N \quad D \quad I \quad X$.}

Names of the Towns. Value of the rata Value of the rats. Numb. of

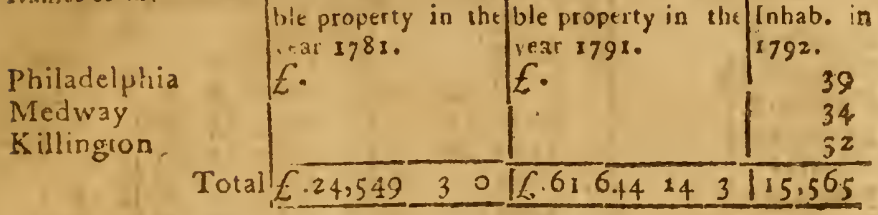

ORANGE COUNTY.

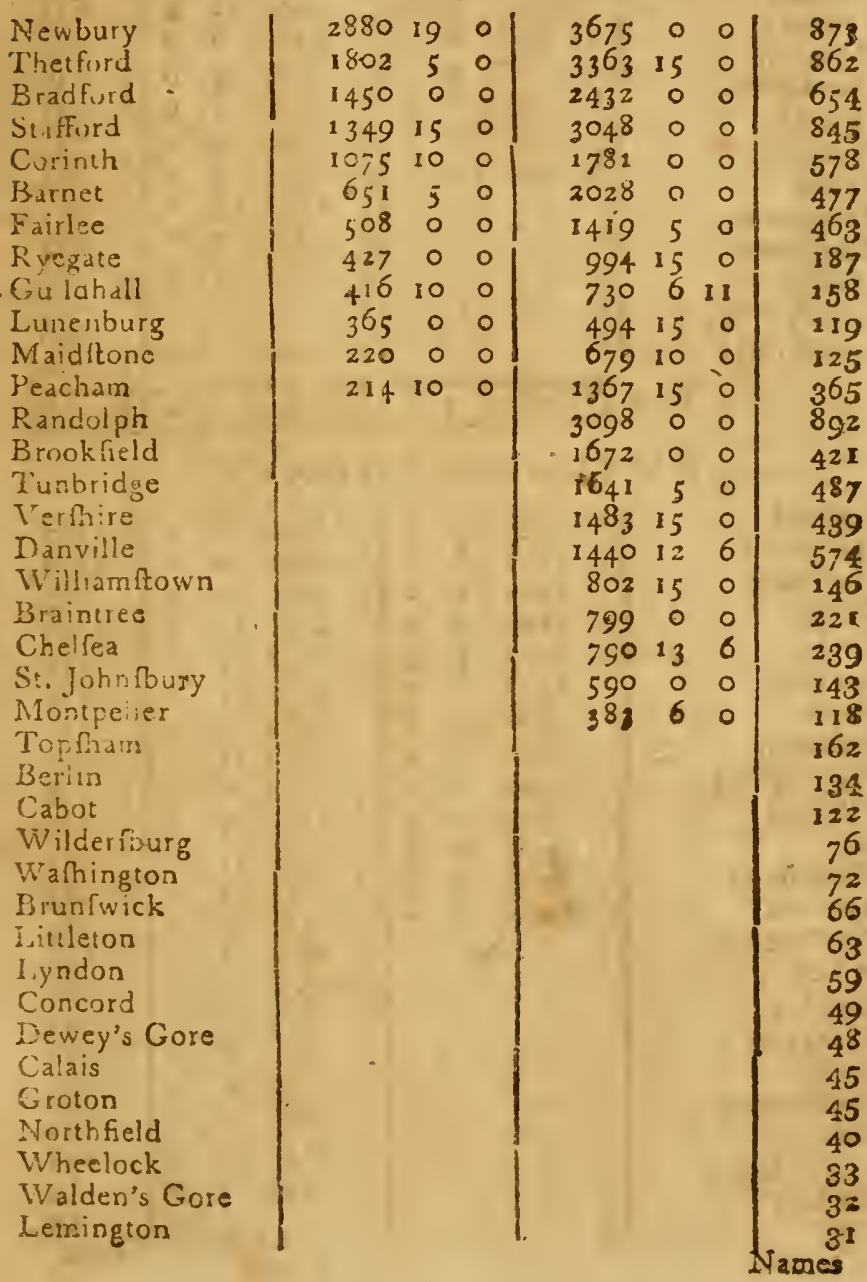



408
$\begin{array}{lllll}A & \mathrm{P} & \mathrm{P} & \mathrm{E} & \mathrm{N}\end{array}$
D. I $X$.

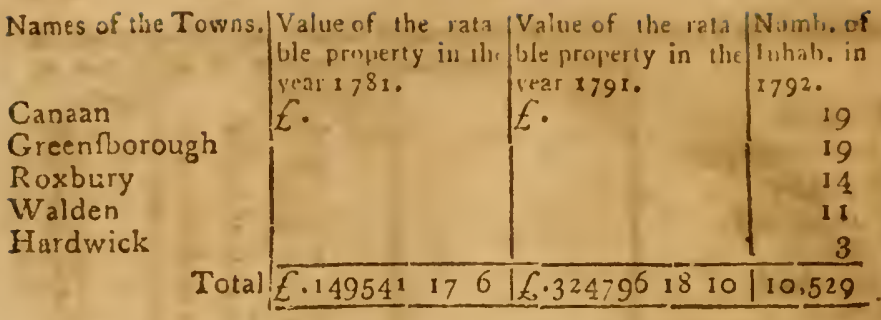

ADDISON COUNTY.

Cornwall Newhaven Salifbury Shoreham Bridport Monkton Addifon Ferrifburg Leicefter Whiting Vergennes Middleborough Weybridge Panton Briftol King fton Hancock

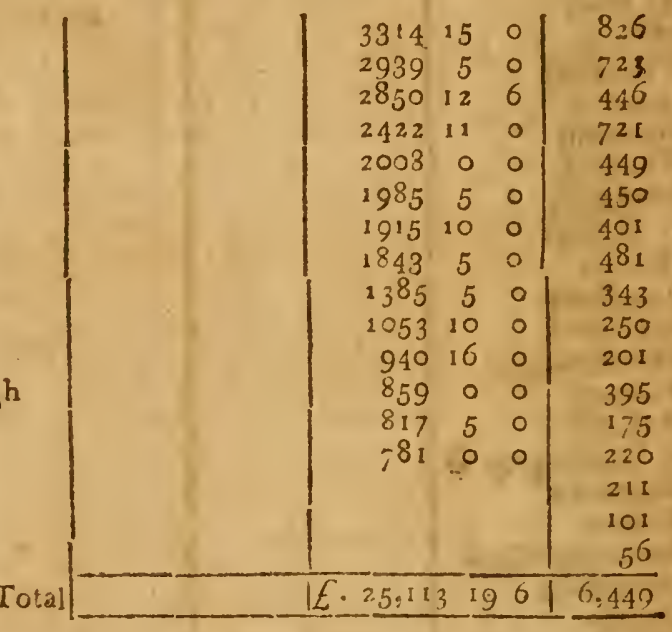

Charlotte Willifton South Hero Shelbuine Jericho Hinelburg Cambridge It:IFex

Georgia Burlington Milton St. Albans Fairfax North Hero Colchelter

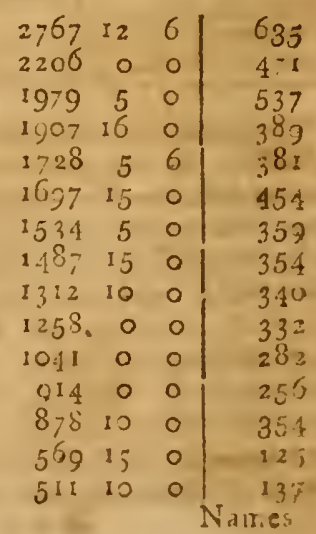




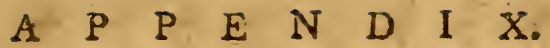

409

Names of the Towns. Value of the ratable Value of the rata- Numb. of

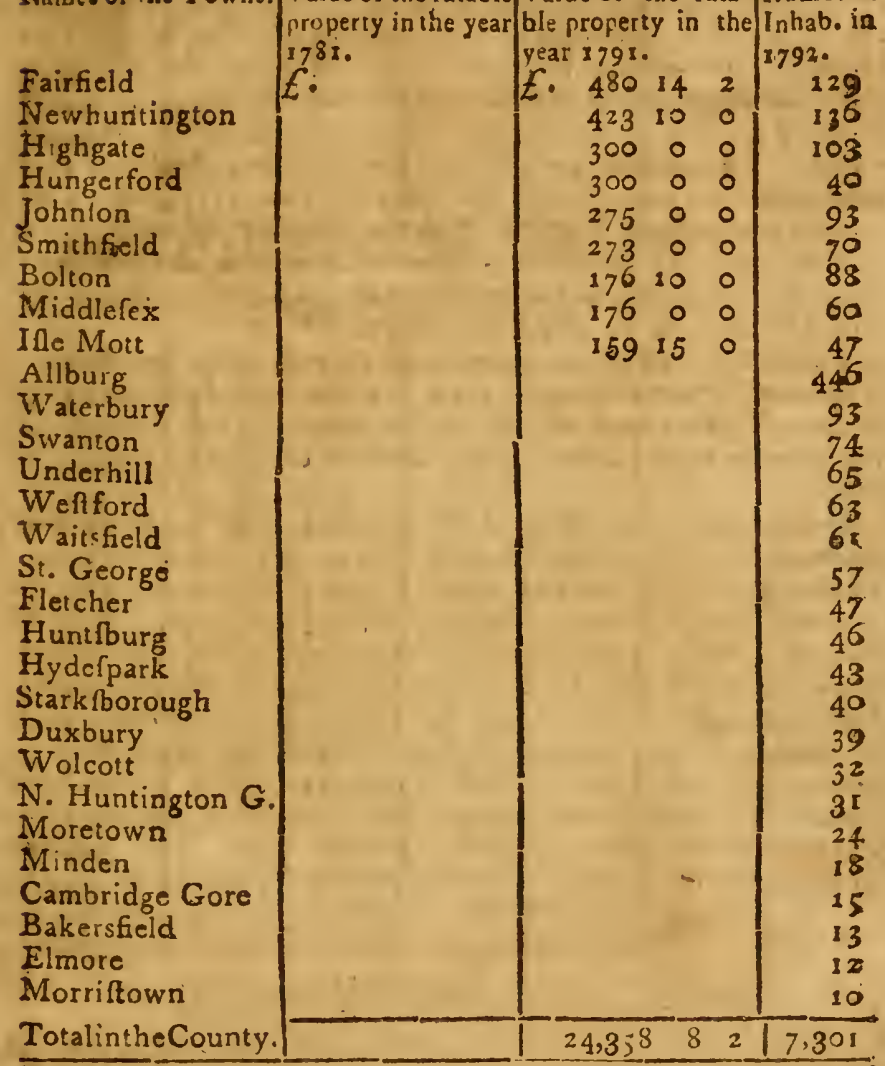

Total in the State.|E.149,541176 1E.324,7961810/85.539.

The above are the lifts which were given in to the General Affembly, by the particular towns, in conformity to an aहt of the le: fature.-In computing the value of the lift taken iri \$791, the prices of fome of the capital articles were shus tated by the Affembly :-Improved land, ten Thillings per acre. Neat cattle, one yea-old, fifteen frillings per head; two years old, thirty fhillings per head; three ycars old and upwards, forty fhilings per head: An ox, four years old, and upwards, three pounds. Horfes, one year oid, twenty Millings; two jedis uld, forty fhillings; thece years old, and upwards, four pounds. - As thele prices were fcarcely one half of the current prices of thcle articles, the real value of the ratabie property $D d d$ 


\section{A $P$ P E N D I Y Y}

of the ftate, mult have been double of what was fet down in the lifts. It is probable this was allo the cafe wi h the lifts taken in 1781 . - But although neither of thefe lift; will givo the exact value of the taxable property of the ftate, at either of thofe periods, they will give the increafe, or the relative value of the taxable property at thofe times: And we can clearly doduce from them, that from the year $178 \mathrm{I}$, the whole ratable property of $V$ ermont became doubled, in eight years and an half. In Virginia, the period at which the value of their lands and flaves taken conjunEly, coubles, is ftated by Mr. Jefferfon, to be about twenty years.*

The number of towns reprefented in 2781 , was fixty three : The numb r reprefented in $179 \mathrm{r}$, was one hundred and twenty fix. Thofe towns which are not taxed or reprefented, do not give in to the affembly any account of their ratable property.

No proper enumeration of the inhabitants of Vermont, was made, before the cenfus taken in 1792. The general eftimations of the affemblies and agents before thas time, were merely conjeftural. - From a report, which Governor 'Tryon of Newyork made to the king of Greatbritain, of the ftate of that province in the year $177^{2}$, it appears that he had procured a lift of the inhabitants of each county in that province: Two of thofe counties, Cumberland, and Gloucefter, were in Vermont; and contained the tract of country, wbich lies on the caft fide of the green mountains, and is no $w^{\prime}$ formed into tho counties of Windhain, WVindfor, and Orange. The number of people in thofe counties in the year $177^{1}$, was as follows

* Nutes on Virginia, p. 388. 


\section{$A \quad P \quad P \quad E N \quad N \quad D \quad I \quad X$.}

\begin{tabular}{|c|c|c|c|c|c|c|c|c|c|c|c|c|c|}
\hline & \multicolumn{5}{|c|}{ Whites. } & \multicolumn{2}{|c|}{11} & \multicolumn{4}{|c|}{ Biacks. } & \multicolumn{2}{|c|}{ II } \\
\hline $\begin{array}{c}\text { Names of the } \\
\text { Councies:- } \\
\text { :- }\end{array}$ & 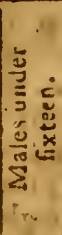 & 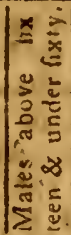 & 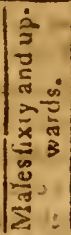 & 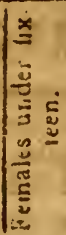 & 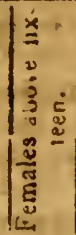 & 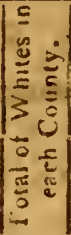 & 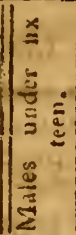 & 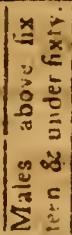 & 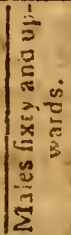 & 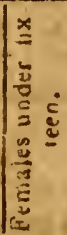 & 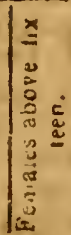 & 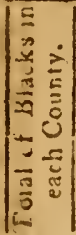 & 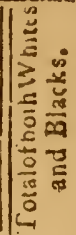 \\
\hline
\end{tabular}

Gloucelfer. $\mid 1781851 \quad 813931 \times 53175511$

21

41 oi

1) of 711722

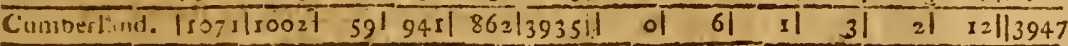

There two Count:cs, at that time, contained about two thirds of the people in the whole diftrict. The whole number of inhabitants therefore in 771 , mult have been about feven :houland. - In the Cenfus taken in 1792 , the numbers ltood thus:

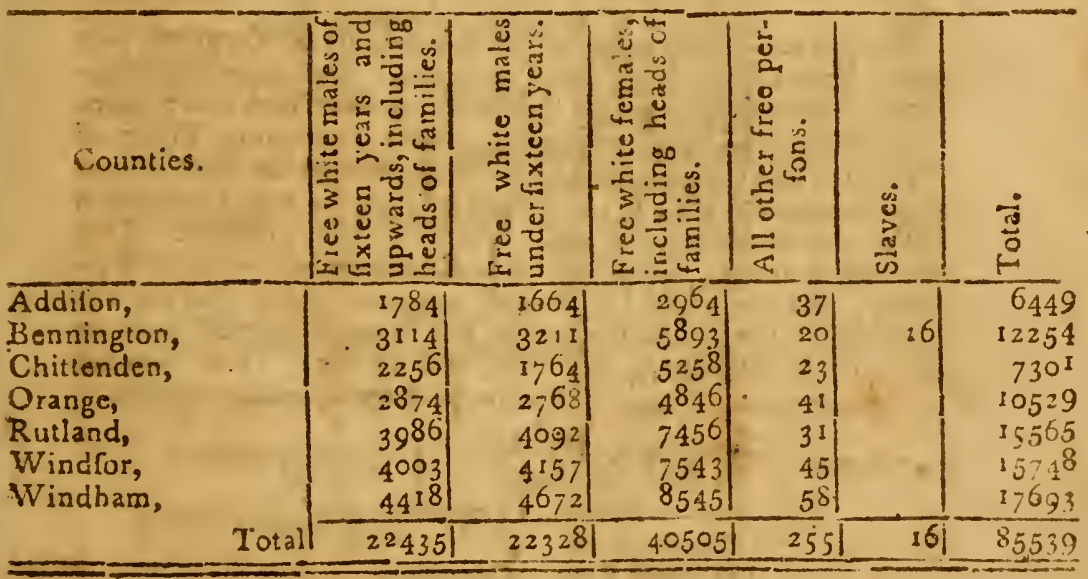

\section{Page line for}

$5^{8}$ in Labontaus

6330 eight

37 dele eight.

70 21 Amur

764 and

1029 aquative

1035 all ${ }_{3} 3$ P scudo

10428 Lзаza

$112 \times 3$ nibro

334 ro mode

14231 fat s.:

3516 adapted sopred.

A un,

are.

able.

ofcudo.

Ziara.

rubro.

rude.

fort.
$E R \quad R \quad A \quad T$ A. read Labunt an. eight tenths.

aquatic,
Page litie for

15421 band

$=609$ to

169 12 adapted

×96 36 have

$3+1 \quad 22$ was

2.4432 he

252 10 free

271 I7 controverfy correfpondence.

2725 brided bribed.

2798 refolutio.s refolutions.

131615 ore ocre.

33536 renes revere.

37126 more none. 


\section{NAMES OF THE SUBSCRIBERS.}

\section{Honoura}

Paine Wingate, $\}$ N. Hamplhire

Caleb Strong,

George Cabot,

Theodore Folter,

Joleph Stanton,

Oliver Ellfworth,

Roger Sherman,

\} Maflachufetts.

\} Rhodeifland.

Conneticu

$\left.\begin{array}{l}\text { Stephen R. Bradley, } 2 \text { copies } \\ \text { Moles Robinfon, }\end{array}\right\}$ Vermont.

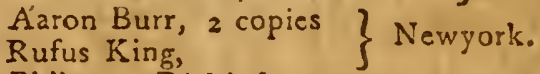

Philemon Dickinlon,
John Rutheiford, Newjerfey.

Robert Morris, Pennilylvania.

$\left.\begin{array}{l}\text { Richard Baffet, } \\ \text { George Read, }\end{array}\right\}$ Delaware.

John Henry, Maryland.

James Munroe, 2 copies, Virginia.

$\left.\begin{array}{l}\text { John Brown, } \\ \text { John Edwards, }\end{array}\right\}$ Kentucky.

Seqjamin Hawkins, $\}$ Northcarolina.

Samuel Johnton,

Pierce Butler, Iz copies, $\}$ Southcarolina.

- William Few, Georgia.

$\begin{array}{llllllll}V & \mathrm{E} & \mathrm{R} & \mathrm{M} & \mathrm{O} & \mathrm{N} & \mathrm{T} \text {. }\end{array}$

His Excellency Thomas Chittenden, Governor.

The Honourable. Peter Olcott, Lieutenantgovernor.

The Honourable Timothy Brownfon,

Samuel Safford,

John Strong,

Ebenezer Walbridge, 12 cop.

Jonathan Arnold, 2 copies,

Paul Brigham,

Ebenezer Marvin,

Luke Knowlton, 2 copies,

Thomas Porter,

Counfellors.

The 


\section{SUBSCRIBERS' NAMES.}

The Honourable Sariue! Mattocks, Treafurer.

Rolewell Hopkins, Efq; Secretary of State.

Joleph Fay, Efq; Secretary to the Governor and Coun. cil.

The Honourable Gideon Olin, Speaker of the Houfe of Rep. refentatives, 3 copies.

Samuel Knights, Chief Juftice of the Supreme Court.

Elijah Paine, Juftice of the Supreme Court. Ifaac Tichenor, Juftice of the Supreme Court. Nath. Chipman, Judge of the Diftrikt Court, 2 copies.

Samuel Hitchcock, Elq; Attorneygeneral.

A.

Aaron Adams.

Jeremiah Adams.

Edwald Aiken.

Jofeph Allen.

Bamuel C. Allen.

James Allen.

Caleb Allen.

Rev. Jonathan Allen.

Majorgeneral Ira Allen.

Levi Allen.

William Alvord.

Dr. Abel Allis.

Robert Anderfon.

Reuben Atwater, Efq.

Capt. Elifha Averil.

Elijah Avery. B.

Benjamin P. Baldwin.

Frederic Baldwin.

William Baker.

Tilley Ballard

John Bancroft.

Rev. Thomas Barnard.

Jonathan Barrett.

Thomas Barrett.

John Barron.

Dr. Prefcott Barron.

Frye Bayley, Efq

John G. Bayley, Eqq.

Ifaac Bayley, Efq.

Joleph Bayley:

Samuel Beach.

Moody Bedel, Elq.

Jonathan Bell, Efq. 2 copies.
John Benediet.

Mofes Bennett.

Alfred Bingham.

Silas Bingham.

Sclomon Bingham.

Elijah Blake.

John W. Blake.

Rev, Enos Blifs.

Charles Boyle.

Joleph Bradford.

Ifaac Brevoort.

John Bridgman, Efq.

Rev. Aaron.Jordan Booge.

Samuel Brown.

Profper Brown.

Bryant Brown, Erq.

Ebenezer B jown, Efq.

Elinha Brown.

Daniel Buck, Efq.

Major Elias Buel.

Thomas Bull.

Abraham Burnham, Erq.

John Burnam.

Benjamin Burt, Elq.

Jonathan Burt.

Joleph Cable.

Dottor Jofeph Cäldwell.

Dr. Alex. Campbell, 2 copies.

Dr. John Campbell.

Matthew Carey, Iz copies.

Philip Carigain.

Biffel Cale.

Louden Cafe.

Abbe Cady. 
Nithaniel Chamberlain. William Chambetlain. Gardner Chandler, Efq. Jeffo Chandler. Thomas L. Chandler. Ifaac Chatterton.

Dr. Cyrus Chipman. Daniel Chipman, Elq. Darius Chipınan, Efq. Lemuel Chipman, Elq. John Chipman, Efq. Samuel Chipman, Lifq. Col. James Claghorn. Eleazar Claghorn, Efq. Jofeph Clark. Ozias Clark. John Clayton. Edward Clifford. Capt. John Cobb. Samuel Cobb. Brigadiergeril. Eli Cogfwell. William Coit. John Cook. Caleb Coolcy. Stephen.Coolidge.

Ozias Crampton. Samuel Cutler, Elqa: John Curtis Zebina Curtis,

Ezra Dean. D.

William Denifon. Elijah Dewey, Efq. Ormond Doty. Peleg Douglars. Mofes Dow, Efic. Jafon Duncan. Ifaac Duffs. Jofiah Dunham, 12 copies. Salmon Dutton, Efq. 2 copies. Ifaac Ellis.

Peter Evans.

Zadoc Everilt.

James Enrss.

fames Lnos, jun.

Majorceneral RogeriEnos, James Eusing, Efri.
F.

Rev. Daniel Farrand.

Daniel Ferrand, Efg.

David Fifk.

Miores Firk.

John Fitch, Erq. Alaph Fletcher, Elq. Samuel Fletcher, Efq. Mills D. Foreft, E?q. Jabez Folter.

Rev. Robert Fowle.

Col. John Fuller.

G.

Jonas Galurha, Efq̣.

Elijah Garfield.

Jonathan Gates.

Willeby Goodwin.

Nathaniel Gove.

John A. Graham, Efq, 2 cop:

Ala Graves.

Benjamin Green, Elq.

Ifaac Green.

Nathaniel Green, Erqq.

Sylvanus Gregory.

John Griffin, Efq.

$\mathrm{H}$.

Nathan Hale, Elq.

William Hale.

Lot Hall, Elq. 2 copies.

Joel Hamilton.

Dr. Z. Hamilton.

H. Hardie, 12 copies.

Ezckiel Harmon.

Joel Harmon

William C. Harrington, Efq, Alex. Harvey, Efq. 2 copies. Dr. Aaron Haftings.

Anthony Hafwell, 12 copies.

Reuben Hatch.

William Havendren.

Joleph Hawley.

Col. Udny Hay.

Rev. Lemuel Haynes.

William Hennefy.

Benjamin Henry.

Frederic Hill, Efq.

Moles Ifinman

Lyman Hitchcock. 
David Eioit.

Elijah S. Hollifter.

Jelle Hollifter.

Sech Holt.

John Hopkins.

Lucius Hubbard, Efq.

John Hubbard.

Jonathan H. Hutbard, Efq.

Arad Hunt, Efq.

John Hunt, Efq.

John Hurd, Elq. I 2 copies.

Richard Hurd.

Rabert Hulton.

Aaron Hutchinfon, Efq.

$J$.

Stephen Jacobs, Erq.

Leonard Jewett.

Afa Johnton, Efq.

Col. Thomas Johnion.

Perez Jones.

Ebenezer W. Judd, Efq. $\mathrm{K}$.

Bradford Kellogg.

Rev. Dan Kent.

Jacob Kento.

Col. Stephen Keyes.

William Kilburn.

Nathaniel Kingley.

Aaron Kinfman.

Ephraim Kirby, Efq.

Elijah Knight.

Calvin Knowiton, Efq. L.

Rev, Nathaniel Lambert.

Luther Largdon.

Rcuben Langdon.

Samuel Lathrop, EIq.

John Law, Efq.

Jefle Leavenworth, 3 copies.

George Leonard.

William Leverett.

Beriah Loomis, Elq.

Elijah Lovett.

John-Lovett, Efq.

Cornclius Lynce, Efq.

Rev. Afa Lyon.

James Lyon.

Col. Matthew Lyon.
M.

Samuel McCluer.

A fa MicFarland.

John McNeil, Efq.

Jeremiah Mafon, Efg.

Joel Marín.

Nicholas S. Mafters, Efq.

Capt. Ifaac Meacham.

Moulton Morey, Efq.

Brigadiergnl. Lew. R. Morris.

James Morfe.

Conftant Murdock.

Benjamin Muzzy.

W. Mynderfe.

N.

John Nanton.

Nathan Nelfon.

Oliver Noble.

O.

David Oaks.

Elias Olcott, Efq •

Henry Olin.

Jonathan Ormfly.

Nathan Ofgood, 2 copies: $P$.

Jofiah Page.

Benjamin Paine.

Amala Paine, Efq.

Gamaliel Painter, Elq.

Col. Stephen Pearl.

Claancy Pier.

William Pike.

John Pomroy.

Ala Porter, Elq.

Benjamin Porter.

Dr. Ezekiel Porter.

John Porter, Efq.

Joleph Porter, jun.

Kolewell Poft.

Dr. Cephas Prentifs.

Samuel Prentifs.

Nathaniel Prefon.

Jofeph Prince.

Martin Reed.

$\mathrm{R}$.

Dr. Daniel Reed.

Stephen Rice.

A mos Richardfon. 
116.SUBSCR IB ERS' N A MES.

Johua Ricker.

John Ripley.

Phineas Riploy.

Chriftopher Roberts.

Joel Roberts.

Hon. Jeffe Root.

William Round.

$S$.

Silas Safford, Efq.

David Sanderfon.

Major James Sawyer.

Col. Thomas Sawyer. Andrew Selden, Elq.

Jofeph Selden.

Aaron Sexon.

David Sheldon.

Nathaniel Sheldon:-

Samuel Shepardfon.

John Shumway, Efq.

Rev. Samuel Shuttlefworth.

Walter Sloan.:

Jacob Smith.

John Smith.

Jonathan Smith.

Ifaac Strith, Efq.

Ifrael Smith.

Simeon Smith, Efq.

Prince Super.

Col. John Spafford.

Simeon Spencer.

Eliakim Spouner, Efa.

Trumau Squier.

John Stacey.

ielias Stevens,

Abijah Stone, Elq.

David Stone.

Phineas Stone.

Villiam Storer.

Seth Storrs, Eif.

Cinpman Swift, Éq.

$T$.

Mansfield Taplin, 2 copies.

Ala Tenny.

Vilina Thayer.
Rev. Lathrop Thomfon.

Thomas Thomfon.

Stephen Thorn.

Timothy Todd.

Thomas Toleman.

Col. Orange Train:

Nahum Trak.

George Trimble.

Turell Tufis.<smiles>[AlH2]</smiles>

James Underhill. W.

Samuel Walker. Samuel Ward.

Azel iValhburn.

Calvin Webb.

Jehiel Webb, Efq.

Dr. Jamua Webb.

Noah Webfter, Efq.

Jabez H. Weld.

Shipley Wells.

Elijah Weft.

Jedediah Weft.

Eli Wheeler.

Afa Wheelock, Efd,

John White, Efq.

Nathaniel White.

Dr. Samuel White.

James Whitelaw, Efq. 2 cop.

Rev. Samuel Whiting.

Benjamin Whitman.

John Whitman.

Brigadiergenl. Dav. Whitney.

John Whitney.

James Whitney.

Lemuel Whitney.

Richard Whitney, Efa.

Elias Willard, jun.

Samuel Wiliams, Efa.

D.. James Whitierel.

Enoch Wuodbridge, EfC.

Jofeph Woodward.

Elcdzer Wright. 


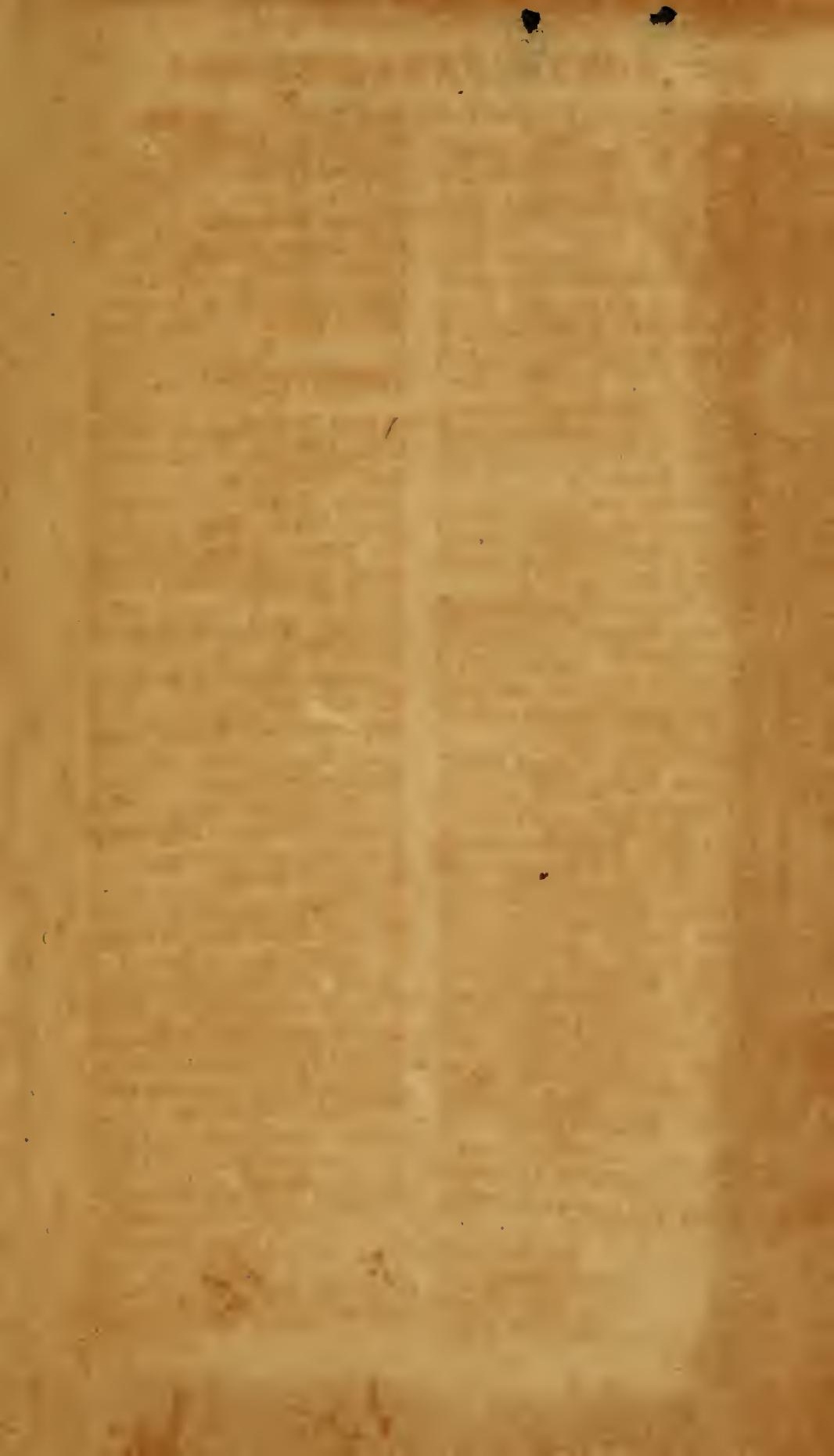



whet 237

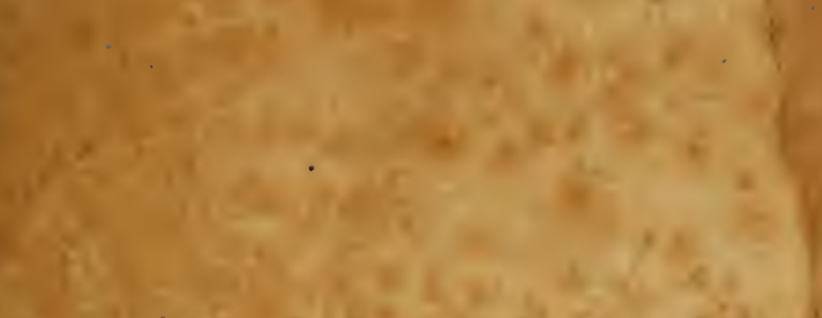

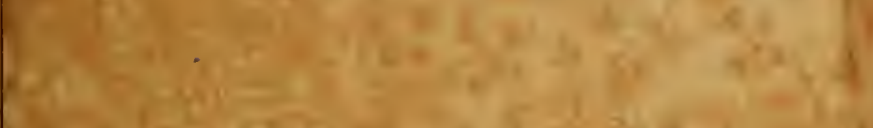

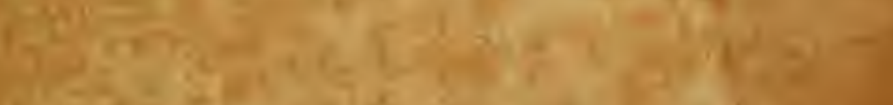

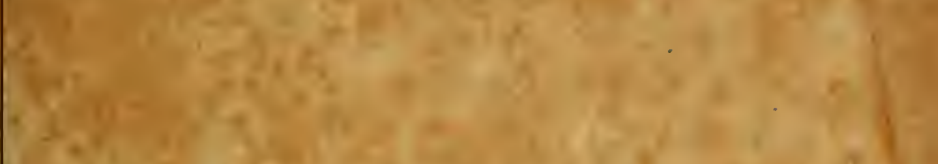

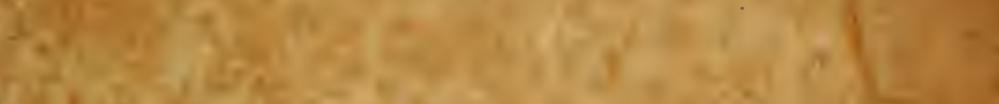

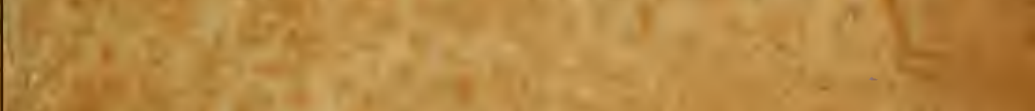

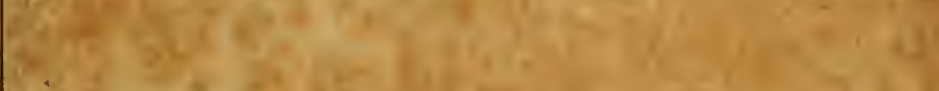

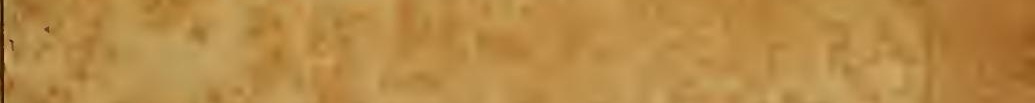

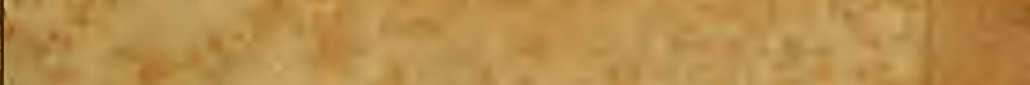

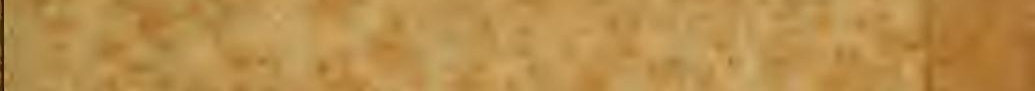

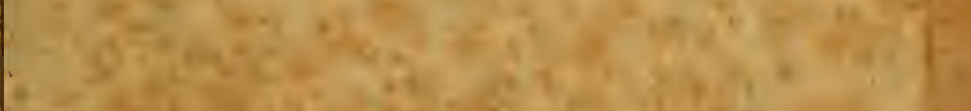

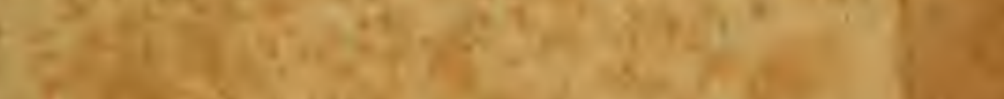

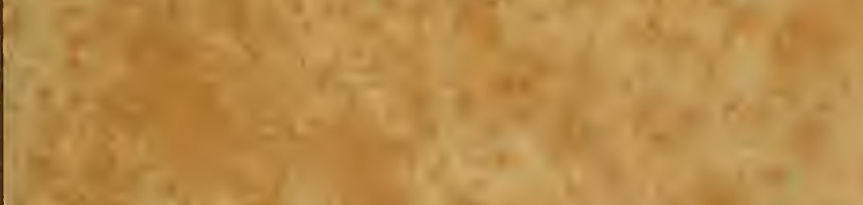

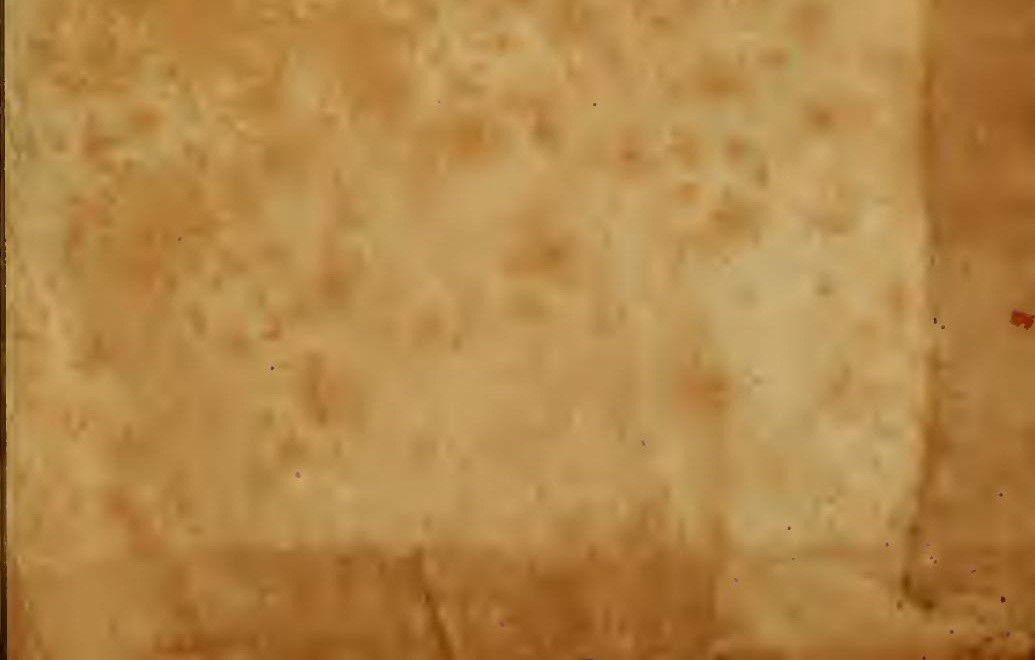




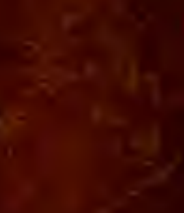

$+y$
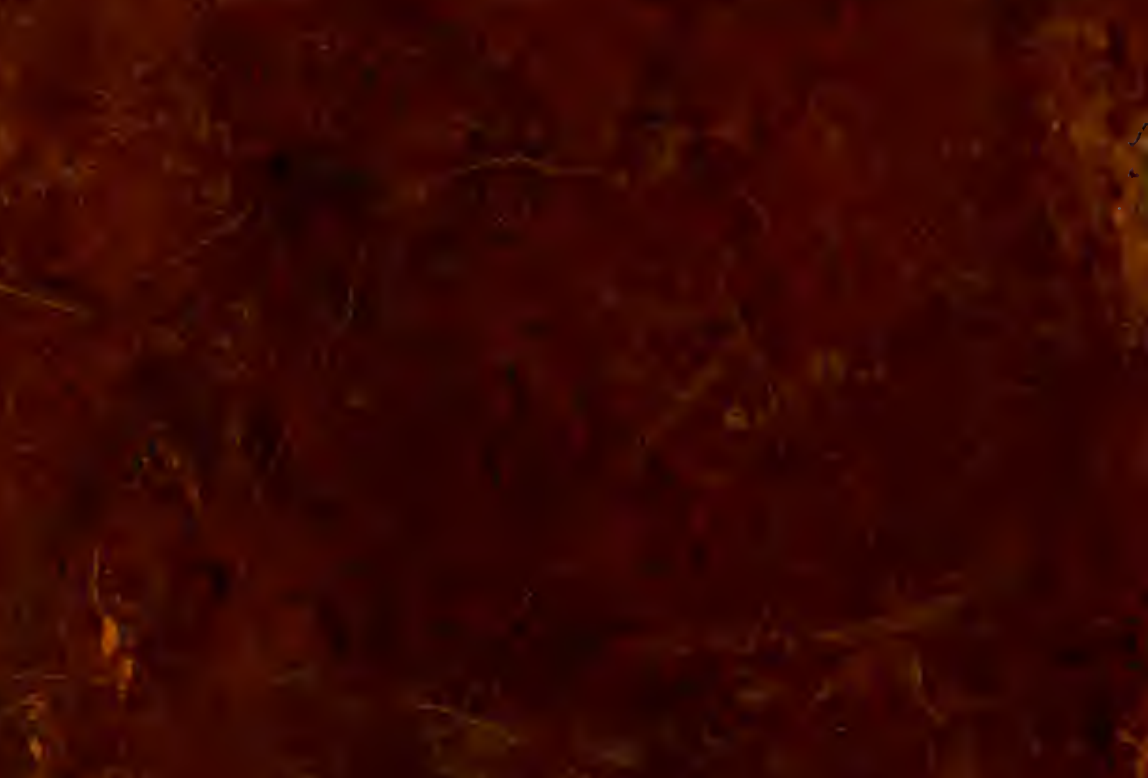

$2,5 * 2=$

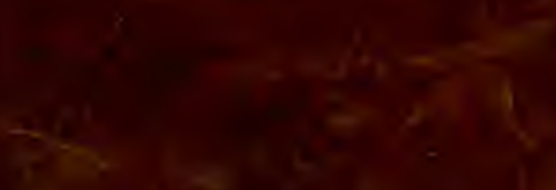

$-7$

$+2$

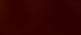

